
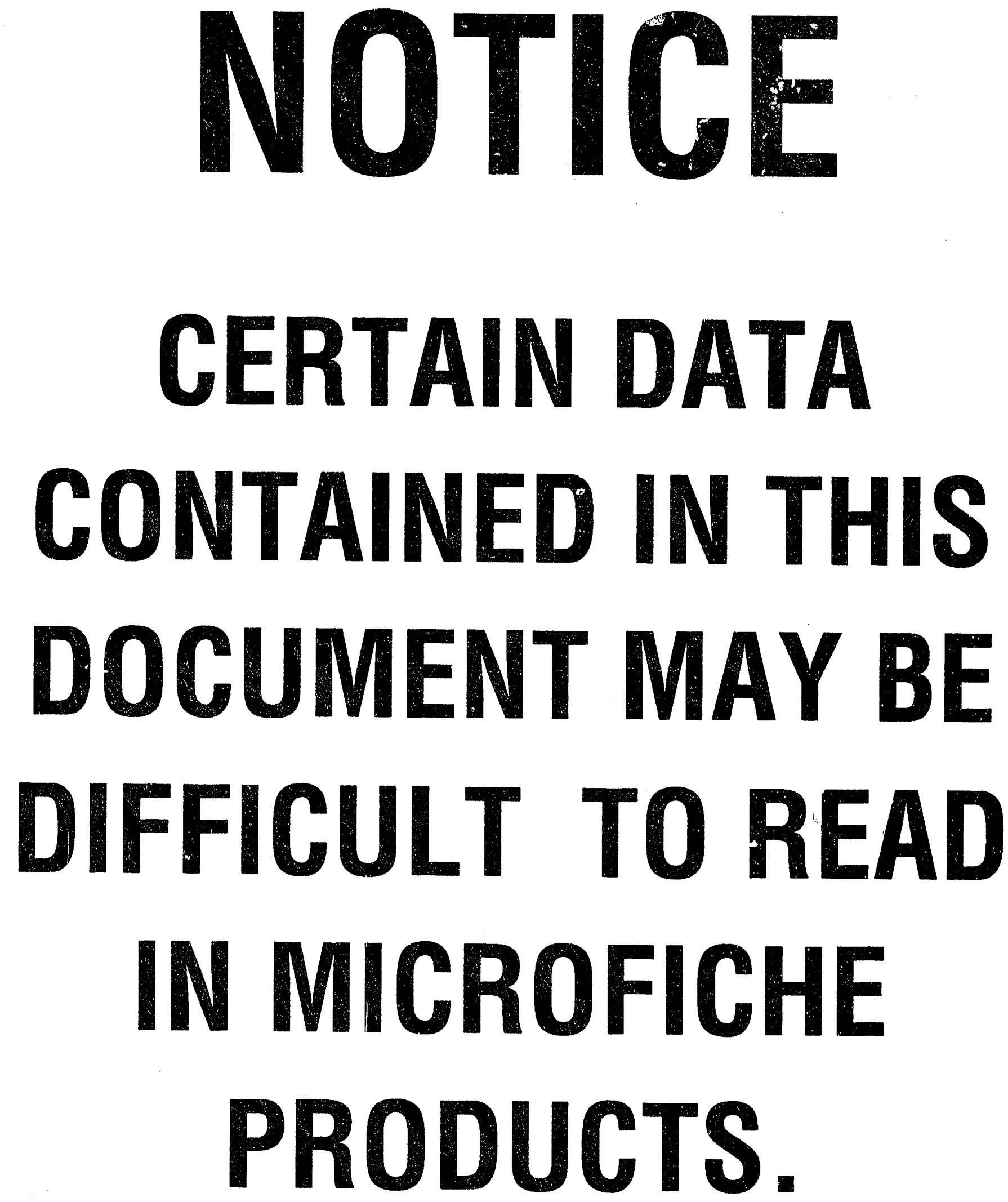
1.0 EXECUTIVE SUMMARY

2.0 INTRODUCTION

2.1 Project Background and Description

2.2 Objectives

3.0 GEOLOGIC SETTING

3.1 Regional Setting

3.2 Site Geology

4.0 DRILLING PROGRAM

5.0 TECHNICAL APPROACH

$\begin{array}{ll}6.0 \text { WELL SUMMARIES } & 20\end{array}$

$\begin{array}{ll}\text { 6.1 AMH-1 } & 20\end{array}$

6.1.1 Preliminary Work . 20

6.1.2 Drilling Performance 20

6.1.3 Well Installation $\quad 22$

6.2 AMH-Z-. 22

6.2.1 Introduction 22

6.2.2 Drilling Performance: First Attempt 24

6.2.3 Drilling Performance: Second Attempt $\quad 24$

6.2.4 Drilling Performance: Third Attempt 24

6.2.5 Well Installation: First Attempt 25

6.2.6 Drilling Performance: Fourth Attempt 25

6.2.7 Drilling Performance: Fifth Attempt 26

6.2.8 Well Installation: $\mathrm{AMH}-2 \quad 27$

$\begin{array}{ll}7.0 \text { DISCUSSION } & 32\end{array}$

7.1 Analysis of Drilling Program $\quad 32$

7.2 Analysis of Drilling Fluid Program 34

7.3 Analysis of Well Design 36 


\section{Page}

$\begin{array}{lll}8.0 & \text { CONCLUSIONS } & 38\end{array}$

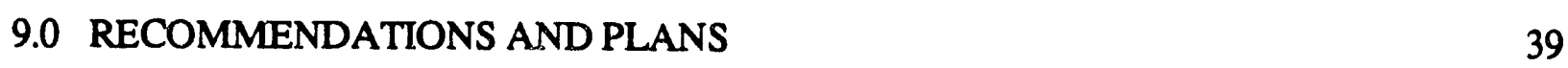

9.1 Recommendations 39

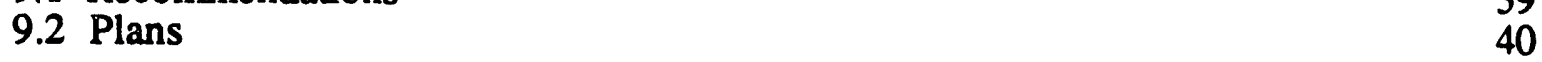

$\begin{array}{ll}10.0 \text { SELECTED REFERENCES } & 41\end{array}$ 


\section{Eigures}

Page

2.1 Location Map

2.2 Study Area Location Map

3.1 Generalized Geologic Column 9

$\begin{array}{ll}\text { 4.1. A Curved Drill Guide } & 14\end{array}$

$\begin{array}{ll}\text { 4.1. B Rigid Drill Mandrel } & 16\end{array}$

$\begin{array}{ll}4.2 \text { Schematic Diagram of Whipstock Assembly } & 17\end{array}$

6.1 AMH-1 Well Construction Diagram 23

6.2 AMH-2 Well Construction Diagram 28

6.3 Isometric and Plan View of Final AMH-1 AND AMH-2 Boring Alignments 30

6.4 Cross-sectional Views of Final AMH-1 AND AMH-2 Boring Alignments 31

7.1 Cross Section of Both Horizontal Wells 33

Tables

3.1 Sieve Analysis and Permeability Data 
A. Geologic Log

AMH-1

B. Geophysical Logs

C. Drilling Program Plans

AMH-1

AMH-2

D. Directional Drilling Data

Down-Hole Survey Data AMH-1

Down-Hole Survey Data AMH-2

E. Well-Casing Tallies

AMH-1

AMH-2

F. Conoco Well Report Summary Data

Well Data Summary

AMH-1

AMH-2A, -2B, -2C, -2D, -2E

Drilling Fluid Performance

AMH-1

AMH-2

Directional Drilling Performance

AMH-1

AMH-2

- iv - 


\subsection{EXECUTIVE SUMMARY}

Two horizontal wells were installed in the M-Area of the Savannah River Site (SRS) adjacent to an abandoned process sewer line to test new methods of in-situ remediation of soils and ground water. Documented leaks from the process sewer have contaminated the underlying vadose zone and ground water with volatile organic compounds (VOCs). A deep horizontal well, installed below the water table, is to be used as an air-injection well to purge organics from the contaminated ground water. The shallow horizontal well, installed in the vadose zone, is to be used to remove vapor-phase volatile organic compounds from the vadose zone and to recover the organics purged from the ground water.

The objective of this part of the research project is to determine the feasibility of installing horizontal wells in the unconsolidated sediments underlying the Savannah River Site. Horizontal wells were selected for injection and extraction because this geometry should maximize the surface area available for in-situ remediation reactions to occur and because this geometry has many applications for environmental work, such as drilling below existing facilities. The second phase of the research project, to begin within a few months, is to test a combination of air injection and vapor extraction as a new remediation technology.

The vertical section of the deep well (AMH-1) was cored continuously to a depth of 196 feet to characterize the geology of the site. The core hole was also geophysically logged. Target zones for the laterals were selected on the basis of (1) concentrations of volatile organic compounds in ground water from nearby monitoring wells and (2) porosity analyses. The deep air-injection well (AMH-1) was targeted at a depth of 151-157 feet, in a highly permeable zone that is known to contain elevated levels of volatile organic compounds. The shallow well (AMH-2) was targeted in a permeable sand at a depth of approximately 65-75 feet.

The drilling program relied heavily on expertise and equipment from the petroleum industry. Short-radius directional drilling tools were used to drill the curved and lateral portions of the holes. Expected radius of curvature was approximately thirty-five feet. The tools included a non-rotating curved drill guide, flexible drive pipe, an orientation assembly, and a stabilized straight-drilling assembly.

Whipstocks, designed to guide the curve-drilling guide during the initial part of the curve, were grouted in place at the calculated kick-off point for each hole. The curves were drilled using a 6 1/4-inch tri-cone roller bit and the curve-drilling guide. Single-shot and multi-shot deviation surveys were performed at selected intervals to determine both inclination and azimuth of the borehole. The laterals were drilled using a 6 1/4-inch tri-cone roller bit and two undersized stabilizers.

The whipstock for $\mathrm{AMH}-1$ was oriented at approximately $\mathrm{N} 15 \mathrm{~W}$ with a kick-off point of 115 feet below ground surface. The curve was completed within acceptable bearing limits at N $15 \mathrm{E}$. During the drilling of the lateral to a measured depth of 484 feet, the hole drifted further to the east. The hole was reamed; then, a final single-shot survey was run. At this time, circulation was stopped for approximately one hour. As a result, the drill pipe became stuck in the hole. All attempts to loosen the drill pipe were unsuccessful. The hole was salvaged, however, by installation of $23 / 8$ inch perforated tubing throughout the lateral (approximately 300 feet) for injection of air.

Several attempts to install well AMH-2 were unsuccessful. The well location was moved to the east side of the process sewer line and the whipstock was installed at an orientation of $\mathrm{N} 05 \mathrm{~W}$ with a kick-off point of 25 feet. The curve was completed at an acceptable bearing of $\mathrm{N} 12 \mathrm{~W}$. The lateral was drilled to a measured depth of $283 \mathrm{feet}$, with a final azimuth of due north. No 
reaming of the hole was attempted. Four and one-half inch stainless steel wire-wrapped screen was installed to a measured depth of 232 feet to complete the vapor extraction well.

A tremendous amount of knowledge was obtained during the drilling and installation of the two test wells. Factors of importance to be considered during design of another horizontal well drilling program follow.

(1) Trips in and out of the borehole should be minimized to maintain hole stability. No reaming to enlarge the hole should be attempted.

(2) Drilling fluid performance should be maximized by utilizing a low solids, low weight, moderate viscosity, high lubricity fluid. Interruption of drilling fluid circulation should be minimized.

(3) Well materials should possess adequate flexibility to negotiate the curve. A flexible guide should be attached to the front of the well screen to guide the screen downhole.

(4) Sands containing a minor amount of clay are recommended for completion targets, as better drilling control in the laterals was obtained in these sections. 


\subsection{INTRODUCTION}

\subsection{Project Background and Description}

A project to drill and install two horizontal vapor extraction/air-injection wells at the Savannah River Site (SRS), Aiken, South Carolina, was performed in September and October of 1988. This study was performed to test the feasibility of horizontal drilling technologies in unconsolidated sediments and to evaluate the effectiveness of in-situ air stripping of volatile organics from the ground water and unsaturated soils. The study area is shown on Figure 2.1.

Recent hydrologic investigations at SRS have shown that plant operations have resulted in the contamination of the ground water with volatile organic compounds (VOCs) near the M-Area Settling Basin. The contamination at this site resulted from the leakage of waste solvents from a tile process sewer into the vadose zone. The layout of the site and the process sewer line are shown on Figure 2.2. A remedial action program consisting of ground water pumping followed by above-ground air-stripping has been implemented to address ground water contamination in MArea. However, residual concentrations of VOCs present in the vadose zone provide a continuous source of contaminants to the ground water. The estimated life of the above-ground remediation project is thirty years.

In order to test new remediation technologies, the Environmental Sciences Section of the Savannah River Laboratory Division (SRL) performed a successful pilot study of an in-situ vacuum extraction system. The system removed significant quantities of VOCs from the vadose zone, indicating the suitability of vapor extraction technology for the conditions present in M-Area. This remedial design concept was incorporated into SRL's horizontal vapor extraction/air injection well project. In an effort to increase the recovery rate of VOCs from the subsurface and to extend the zone of remediation below the water table, an air-injection system was added to the vacuum extraction design.

Two horizontal wells were installed, one above the water table for vapor extraction and one below the water table for air injection. The deeper well, AMH-1, installed below the water table, was designed to inject air under high pressure, inducing volatilization of VOCs. The shallow well, AMH-2, was designed to extract the vapor phase VOCs from the vadose zone. Acting together, these wells were designed to strip VOCs from the ground water through air-injection and remove them from the subsurface with vapor extraction.

A horizontal well design was chosen to maximize the surface area of well screen in contact with the contaminated material. This should increase the overall efficiency of VOC removal from the ground water and from the unsaturated soils. The wells were constructed of standard stainless steel screens and carbon-steel casing materials and were installed in boreholes drilled with mud rotary techniques and specialized directional drilling tools.

Several subcontractors were retained by the SRL for the design, drilling, and installation of the wells. Conoco Inc. (Houston, Texas) experienced in directional drilling applications, was retained for well design and site operations supervision. Eastman-Christensen (Houston, Texas) was contracted for their directional drilling tools and directional drilling expertise. Graves Well Drilling (Jackson, South Carolina) drilled the exploratory geotechnical borings and provided technical support (equipment, materials and labor) for the drilling and installation of the horizontal wells. D \& M Drilling Fluids (Jay, Florida) was retained by Graves Well Drilling for specialized drilling fluid control. Sirrine Environmental Consultants (Greenville, South Carolina) was retained to (1) provide technical oversight, (2) provide documentation of the project and (3) generate the well-completion report. 


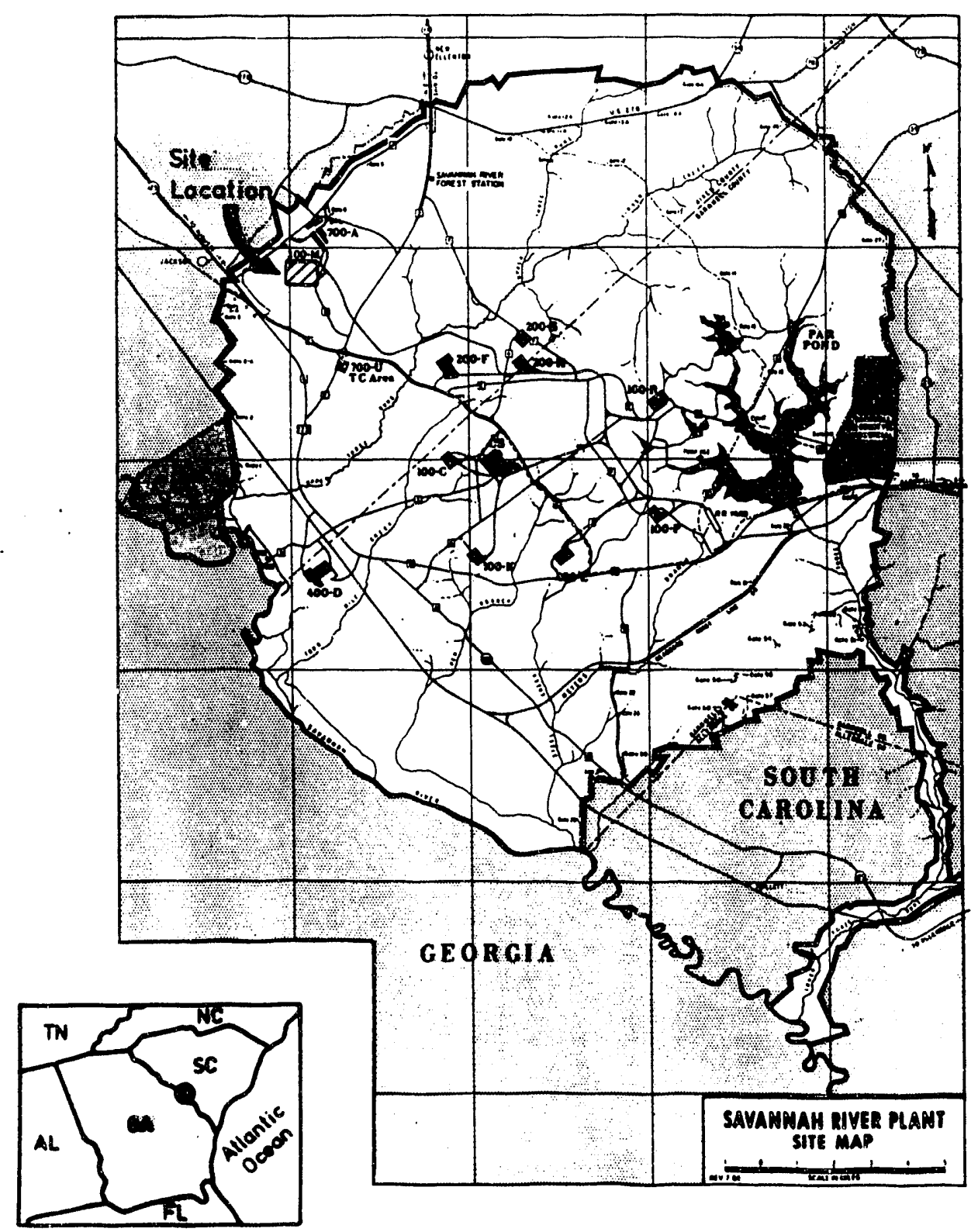

FIGURE 2.1. Location Map 


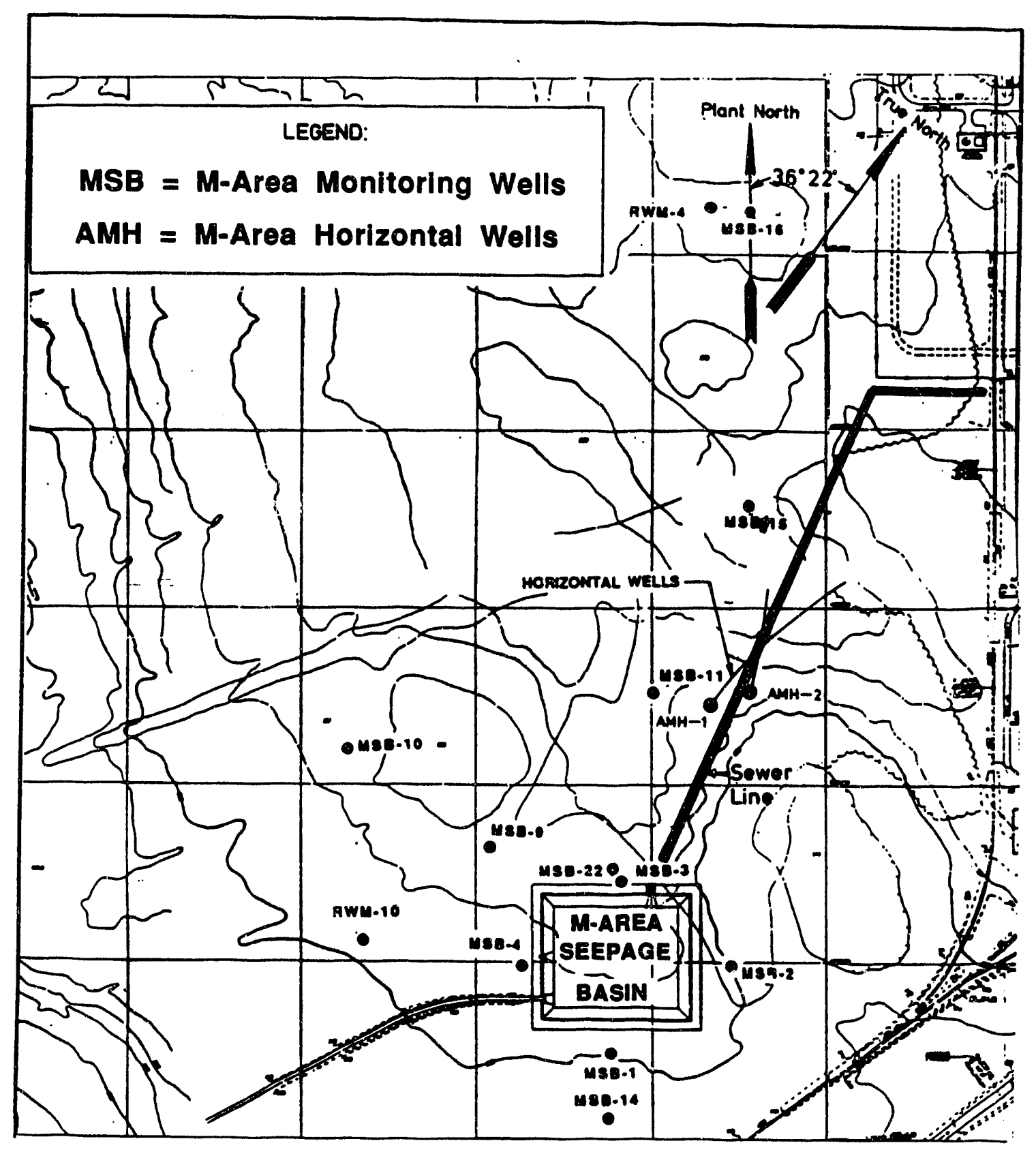

FIGURE 2.2. Study Area Location Map 


\subsection{Objectives}

The overall objective of the research project was to perform a field test that combines two technologies: vapor extraction and air injection. This combination provides for concurrent remediation of both the ground water and the vadose zone.

Specific objectives of this portion of the project were to drill and install two horizontal wells in unconsolidated sediments using short-radius directional drilling technology and to test the suitability of the directional drilling technology for these conditions. 


\subsection{GEOLOGIC SETTING}

\subsection{Regional Setting}

The SRS is located in the Upper Atlantic Coastal Plain Physiographic Province. Within the Coastal Plain Province, the SRS lies on the Aiken Plateau, which is bounded by the Savannah and Congaree Rivers. The surface of the Aiken Plateau is dissected by streams and is characterized by broad interfluvial areas with narrow steep-sided valleys.

The Atlantic Coastal Plain is comprised of a wedge of southeast-dipping unconsolidated and semiconsolidated sediments, which increase in thickness from zero at the Fall Line to more than 4,000 feet near the Atlantic Coast. These sediments range from Late Cretaceous (100 million years) to Holocene (present) in age and extend to the seaward edge of the Continental Shelf. The Coastal Plain sediments generally consist of strata of gravel, sand, silt, clay, and limestone, which were deposited in a variety of fluvial, deltaic, and marine depositional environments. The base of the Coastal Plain sediments lies unconformably on top of crystalline, metamorphic rocks and granitic rocks in the northern portion of the SRS and on top of T'riassic sediments, deposited in a rift basin, in the southern part of the SRS.

\subsection{Site Geology}

Geologic characterization included continuous coring and geophysical logging at the location of well AMH-1 to a depth of 196 feet. The geole sic lng of test hole AMH-1 is included as Appendix A. A second test hole located approx ty 300 feet north of well AMH-1 was also geophysically logged to a depth of approximate; $; 5$ feet, but not cored. Geophysical logs at both locations are included in Appendix B. Drilling was performed with a Failing 1500 rotary rig, and coring was performed with a 94-millimeter, HQ-wireline system with a Christensen core barrel. A Century Geophysical Compulog II system with a model 9040 probe was used to log natural gamma, long- and short-normal (16 and 64 inch) resistivity, and spontaneous potential (SP). Core samples were logged visually according to the modified Wentworth scale. Color was classified according to the Munsellim Color Chart. Sieve analyses were run at selected intervals to confirm visual grain size classification and to identify high permeability intervals for selection as target zones. Porosity and permeability were calculated from sieve data according to the method described by Beard and Weyl (1973) and are presented in Table 3.1.

The sediments encountered during coring consist of alternating sand and clay or clayey sand beds. The sand units range from fine-to coarse-grained and are generally moderately sorted with relatively little silt and clay. Interbedded with the sands are silty clay or clayey sand units, which exhibit relatively low permeabilities. Generally, the clays tend to be thin and discontinuous. Only two clay layers thicker than one foot were observed in the geologic cores from the study area.

Nine distinguishable lithologic units were defined on the basis of (1) changes in the percentage of fines (silts and cleys) in the formation, (2) visual classification (field and laboratory), (3) sieve analyses, (4) borebole geophysical logs, and (5) geologic data from nearby wells MSB-11 and 15. Figure 3.1 schematically illustrates the geology of the site and the two target zones.

The uppermost 32 feet of the geologic section beneath the study area consist primarily of yellowish orange, brown, and reddish purple, moderately sorted, fine- to very coarse-grained sand with 20 to 30 percent fines. Silt and clay occur primarily as matrix material, although a few thin $(<0.3$ feet) clay beds were noted. The unit is finer grained at the top, as the uppermost 12 feet are dominantly silt with accessory clay (15\%-25\%) and sand (5\%-10\%). This unit is unsaturated. 
TABLE 3.1. Sieve Analysis and Permeability Data

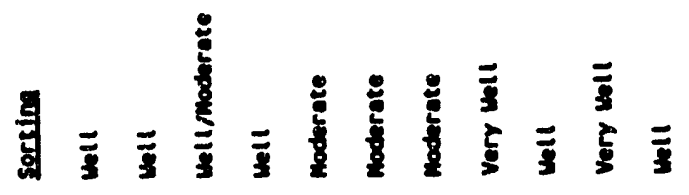

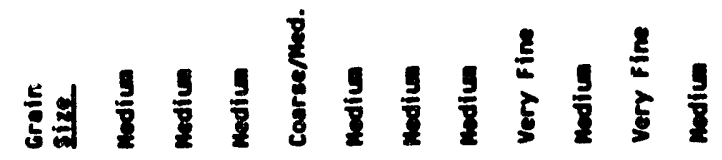

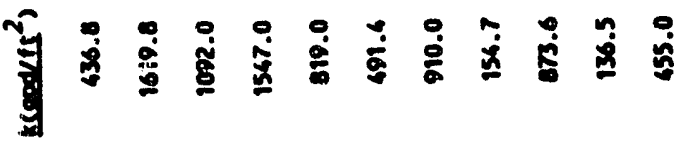

8

is

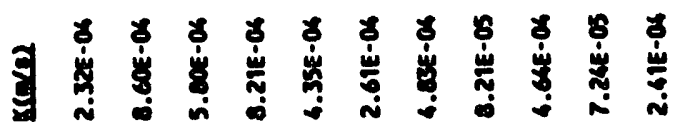

8

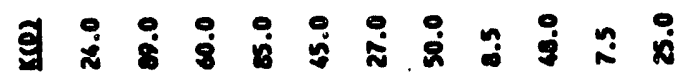

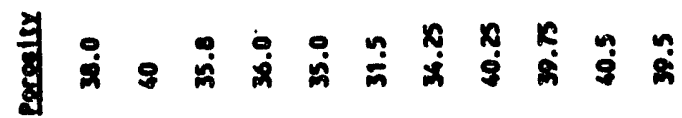

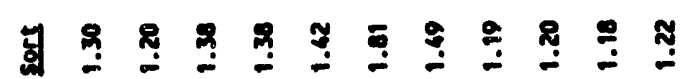

本哭

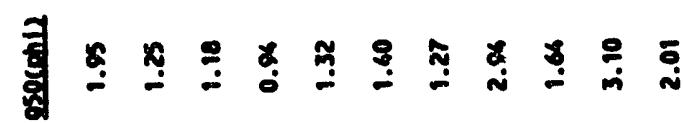

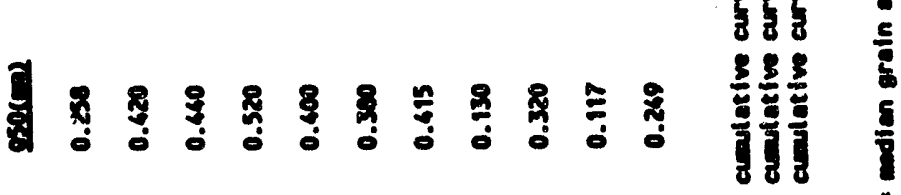

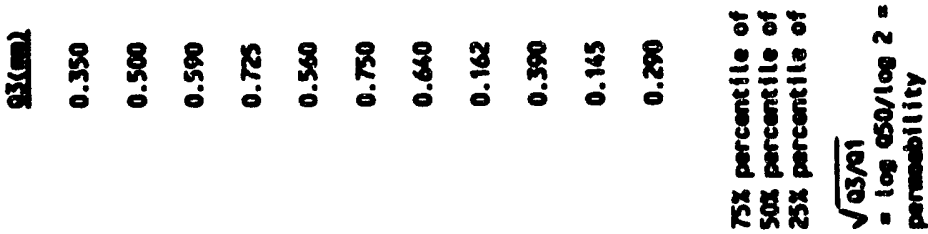

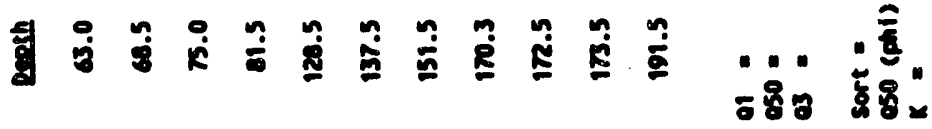

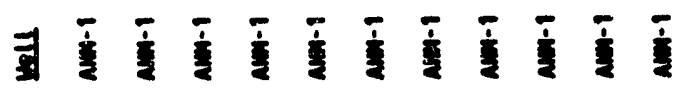




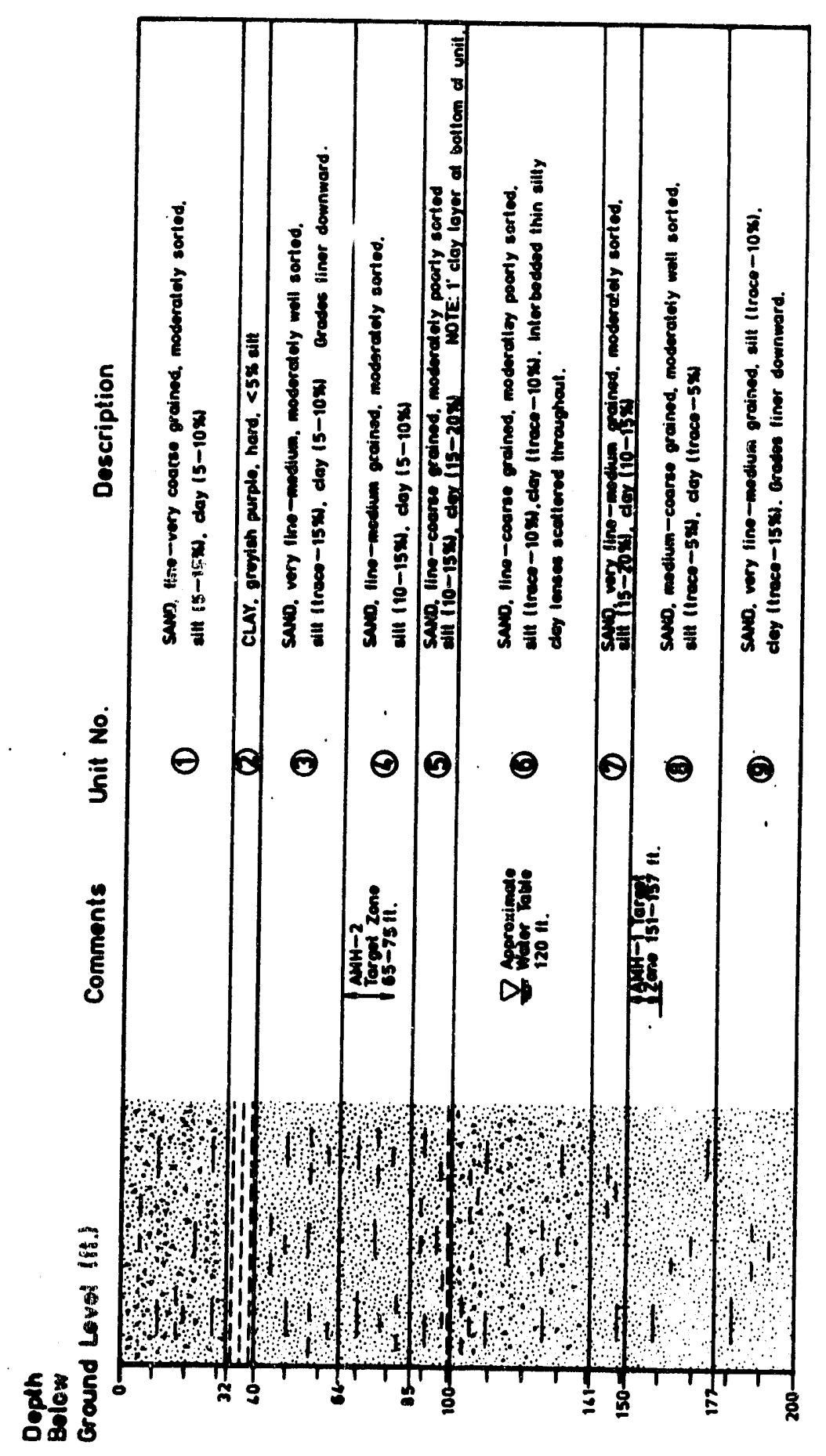

FIGURE 3.1. Generalized Geologic Column 
The second unit, approximately eight feet thick ( 32 feet to 40 feet), is a grayish red purple, hard clay with a trace of silt ( $<5 \%)$. Several thin beds of slightly more silty, yellowish orange clay also occur. This clay unit was also noted on the logs of test holes MSB-11 and -15 . It has a distinctive gamma and resistivity signature. The gamma values (90 to 150 API-GR) are relatively higher and the short-normal resistivity values are relatively lower than those for units one and three (Appendix B).

Unit three, 24 feet thick (from 40 to 64 feet), grades downward from a light brown and orange, moderately sorted, very fine- to medium-grained sand with 10 to 20 percent fines in the upper 15 feet to a browrish gray and reddish purple sand of similar grain size and sorting with a higher percentage of firses (20 to 30 percent). The lower nine feet of this unit are mostly matrix supported and strould have low permeability. The geophysical signature of the upper portion of this unit is siracterized by low gamma values ( 30 to 90 API-GR) and high short-normal resistivities (1800 to $2250 \mathrm{API}-\mathrm{GR}$ ). The lower portion is characterized by significantly higher gamma values (90 to 360 API-GR) and lower short-normal resistivities (1650 to 1950 OHM-M) (Appendix B).

The fourth unit is characterized by a marked decrease in fines and a coarsening in grain size. The unit is primarily a well sorted, medium- to coarse-grained sand with 5 to 15 percent fines. Extending from 64 to 85 feet below ground level, this 21 -foot thick unit was chosen as the target zone for the vapor extraction well AMH-2 because of its coarse grain size, low fines content, and high permeability. Grain-size analyses of four samples from this unit show calculated permeabilities of 2.3 to $8.6 \times 10^{-4} \mathrm{~m} / \mathrm{sec}$ (Table 3.1). Geophysically, it is characterized by relatively low gamma values (30 to 120 API-GR) and relatively high short-normal (16") resistivities (1650 to 2550 OHM-M) (Appendix B).

The fifth unit extends from 85 feet to 99 feet in depth and consists primarily of yellowish orange to brown, moderately sorted, fine- to coarse-grained sand with 25 to 45 percent fines. As is the lower portion of unit three, it is matrix supported and should have relatively low permeability. A one-foot thick silty clay bed was noted in the core and the geophysical log from a depth of 87.3 to a depth of $\mathbf{8 8 . 2}$ feet. However, data from nearby test holes suggest that it is not laterally continuous.

Unit six was the thickest unit identified ( 42 feet), extending from 99 to 141 feet in depth. It consists of yellowish orange to brown, moderately sorted, fine-to coarse-grained sand with 5 to 15 percent fines. Small-scale variabilities in the silt and clay content occur throughout the unit. Several thin ( 1 to 2 feet thick) layers with as much as 25 to 40 percent fines also occur. These layers are indicated on the natural gamma log. However, this unit should be relatively permeable. The water table is encountered at a depth of 124 feet. Resistivity values below the water table are uniformly lower, although relative differences between sand-rich and clay-rich units are still observable.

Unit seven is relatively thin (10 feet thick) and extends from a depth of 141 to 151 feet. It consists of a mottled yellowish orange, moderately sorted, very fine- to medium-grained sand with 20 to 35 percent fines. The unit appeared to have little or no free water even though it occurs below the water table. Unit seven exhibits higher gamma values (90 to 150 API GR) and lower resistivity values than the more permeable unit six above (Appendix B).

Unit eight is similar to unit three in that it grades downward from a relatively clean sand with few fines at the top to a more clayey sand at the base. This 26-foot thick unit extends from 151 to 177 feet below ground level. The upper six feet consist of a yellowish orange to pale gray, moderately sorted, medium- to very coarse-grained sand with less than 10 percent fines. A thin $(2.5$ feet thick), brown, hard clay layer with 35 to 45 percent very fine- to medium-grained sand and 
10 to 15 percent silt marks the transition from the sand-rich upper portion to the more clayey base The bottom twenty feet of this unit consist of a poorly sorted, very fine- to coarse-grained sand with 25 to 35 percent fines. It is more accurately described as finely interbedded ( 1 to 3 inches) clean sand and clay layers. The sands are saturated, whereas the interbedded clays are only moist. The geophysical signature of this unit is low gamma values (15 to 60 API-GR) and slightly higher resistivities, except in the 2.5 foot thick clay layer where higher gamma readings are recorded. The uppermost six feet (151 to $157 \mathrm{feet}$ ) of this unit were chosen as the target zone for the d eper well, AMH-1, because of the coarse grain size, low fines content, higher permeability, and elevated VOC concentrations in the ground water at nearby monitoring wells. Grain-size analysis of a sample from a depth of 151.5 feet produced a calculated permeability of $4.83 \times 10^{-4} \mathrm{~m} / \mathrm{sec}$.

Unit nine extends from 177 feet to the explored depth of 196 feet below ground level. This unit consists primarily of yellowish orange, well to moderately sorted, very fine- to medium-grained sand with 10 to 15 percent fines, interbedded with moderately hard clay with 10 to 15 percent silt. These sands were observed to be saturated. Interbedding with clay layers decreases below 182 feet and the unit becomes predominantly sand with 10 to 15 percent fines. The interbedding in the upper portion of the unit is illustrated in the geophysical log by fluctuating low gamma values (15 to $60 \mathrm{API}-\mathrm{GR}$ ). Resistivities are relatively low for the entire unit (300 to $750 \mathrm{OHM}-\mathrm{M}$ ) (Appendix B).

Overall, the geologic section is characterized by alternating units of permeable sands with low fines content and significantly less permeable clayey sand and clay units. The more permeable units were selected as target zones for the horizontal wells. 


\subsection{DRILLING PROGRAM}

The drilling of the horizontal boreholes was performed by Graves Well Drilling of Jackson, South Carolina. Due to the torque and power requirements for the directional drilling of these horizontal borings, a small petroleum exploration drilling rig was selected. The drilling rig was a DRII TECH DH-1 top-drive hydraulic rotary rig, which supplied 475 horsepower and a maximum torque of 60,000 inch-pounds at 2,100 rotations per minute (rpm).

\section{Drilling Fluid System:}

The drilling fluid system was a crucial part of drilling and well installation, providing efficient removal of drill cuttings and adequate hole stability. Borehole stability was essential for maintaining the integrity of the curve and the lateral portions of the borehole in the soft sediments. D \& M Drilling Fluids, of Jay Florida, managed the drilling mud system for the project.

Solids control, the removal of drill cuttings from the drilling fluid, was achieved by using a plasticlined settling pit followed by a multi-cone hydrocyclone de-silter and a vibratory screen de-sander. All drilling fluid additives were mixed in sectioned steel mud tanks. Mud was circulated down the holes using a Gardner-Denver type, FX-Duplex pump with four 5-inch pistons and a 6-inch stroke. This pump delivers a maximum flow of 150 gallons per minute ( $\mathrm{gpm}$ ) and a maximum pressure of 310 pounds per square inch (psi).

The mud program was modified during the course of the project to improve hole stability, fluid loss control, and overall drilling performance as more was learned about how the sediments reacted to horizontal drilling. The original drilling fluid program called for the lateral drilling to be performed with a bentonite-polymer-freshwater system, which consisted of the following constituents:

- non-peptized bentonite gel,

- partially hydrolyzed polyacryl viscosity and enhanced filtercake formation,

- sized calcium carbonate (sizes 5,50,150 and 600) to increase fluid weight for greater hole stability and to provide bridging material for decreased fluid loss to the formation, and

- fresh water

These constituents were mixed as 23.8 pounds of bentonite and 208 pounds of calcium carbonate to 100 gallons of water with polymer added as needed to maintain adequate viscosity and filtercake formation. This drilling fluid possessed the following fluid characteristics:

- moderate to high solids ( $4 \%$ to $10 \%$ by volume)

- relatively high weight (8.9 to 10.1 pounds/gallon)

- moderate to high viscosity (funnel viscosity 40 to 150 seconds)

- high yield point (15 to 65 pounds/100 feet squared)

However, because complications arose during the drilling and completion of well AMH-1, the drilling fluid program was modified as recommended by the project mud engineer. The drilling fluid was modified to a bentonite-polymer-lignosulfonate-water based system with drilling soap 
and bentonite extender for better fluid characteristics. This system consisted of the following constituents:

- non-peptized bentonite gel for viscosity,

- bentonite extender (Ben-Ex ${ }^{\mathrm{TM}}$ ) to prolong bentonite gel life,

- drilling soap for lubricity,

- inorganic polymers (Baroid Quick-Trol ${ }^{\mathrm{TM}}$ and E-Z Mud ${ }^{\mathrm{TM}}$ ) for greater viscosity with minimal fluid-weight increase and stronger filtercake formation, and

- lignosulfonate, for enhanced filtercake formation.

These constituents were mixed in varying proportions in order to maintain the following fluid properties:

- low solids ( $2 \%$ to $4 \%$ by volume)

- low weight (8.6 to 9.0 pounds/gallon)

- moderate viscosity (funnel viscosity 38 to 45 seconds)

- fairly high yield point (15 to 25 pounds/feet squared)

- high lubricity for improved fluidflow characteristics

Performance of these drilling fluids is discussed in Section 7.2.

\section{Directional Drilling Tools:}

Directional drilling tools and directional drilling expertise were provided by Eastman-Christensen of Houston, Texas. The A-tool short-radius system selected for this work included (1) a nonrotating curved drill guide, (2) flexible drive pipe, often referred to as "wiggly drill pipe," (3) an orientation assembly or "whipstock," and (4) a stabilized straight-drilling assembly or rigid drill mandrel. Each of these components is described below.

\section{Curved Drill Guide}

The curve-drilling assembly is the heart of the short-radius rotary system. It deflects the wellbore from the vertical to the horizontal. This curve-drilling assembly consists of two parts: the flexible drive pipe that ties the vertical string rotation to the curved drill guide and the curved drill guide itself. The curved drill guide, shown in Figure 4.1A, is made of (1) a pre-shaped, flexible shell that gives curvature to the tool, (2) an internal drive shaft that imparts the rotation of the vertical string to the bit, and (3) two sets of bearing packs that connect the non-rotating shell and the internal drive shaft. The bearing packs allow the non-rotating flexible shell to carry the drilling thrust and allow the inner drive pipe to transmit rotational torque. The bit rotates without applying torque to the outer shell, thus allowing the assembly to remain positioned in the curve plane while drilling. Unique cuts on one side of the curved drill guide give the non-rotating shell the flexibility to traverse the vertical portion of the borehole and resume its curved shape when drilling the curve. 


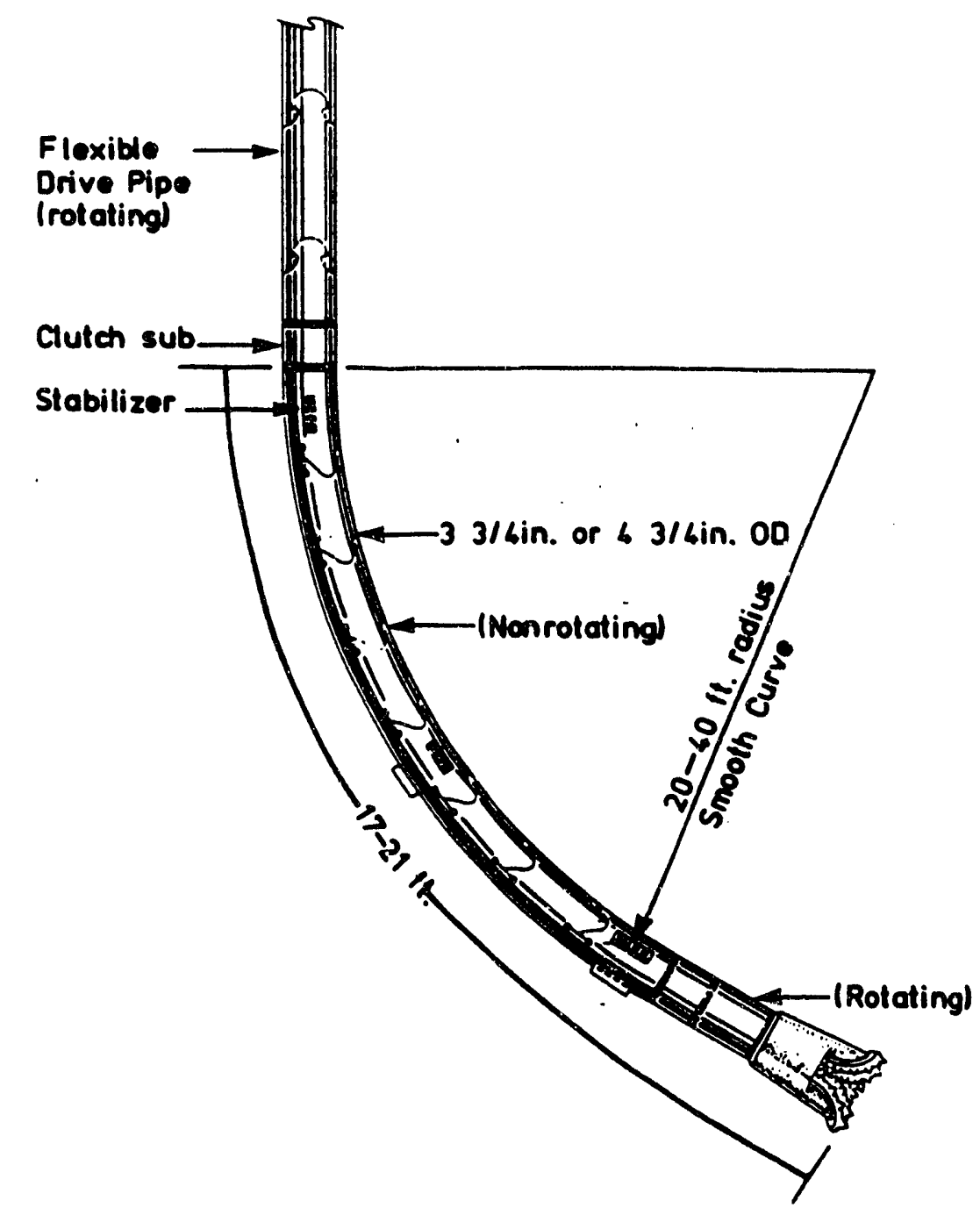

FIGURE 4.1.A. Curved Drill Guide 


\section{Elexible Drive Pipe}

The drive pipe, which is shown on Figures $4.1 \mathrm{~A}$ and $\mathrm{B}$, is standard 4-1/2 inch full-hole modifiedthread drill pipe with cuts in a mushroom shape at one-foot intervals. The cuts give the drive pipe limited flexibility while allowing it to transmit large amounts of rotational torque, downward thrust and upward tensional force. Flexible, sealed inner liners allow the continuous circulation of drilling fluid to the bit.

\section{Rigid Drill Mandrel}

The stabilized straight-drilling assembly or rigid drill mandrel (Figure 4.1.B) maintains the inclination and direction reached at the end of the curve for the duration of the horizontal portion of the boring. The rigid drill mandrel consists of two near-bit, under-gauge stabilizers. By changing the bit angle with different stabilizer combinations, angle-hold, slight angle-build or slight angledrop of the lateral path can be accomplished.

\section{Whipstock}

The whipstock, shown on Figure 4.2 , is essentially a steel pipe, open 180 degrees on one side with a beveled plate that helps the curved drill guide initiate its drilling of the curve. The portion of the whipstock where the curved drill guide first encounters the beveled plate is referred to as the kick-off point. This plate is slightly concave and acts to orient the direction of the curved drill guide as well as initiate the start of the curve.

During all phases of curve and lateral drilling, down-hole surveys are taken to record direction (azimuth) and angle (inclination) of the borehole, thus providing continuous monitoring of drilling performance and progress. Both single-shot and magnetic multi-shot survey tools were used. The single-shot survey tool is pumped down the drill pipe, records only the inclination of the borehole, and is retrieved by a thin wire to which it is attached. This tool provides a relatively quick means of monitoring drilling performance through the curve and lateral portions of the borehole. The magnetic multi-shot survey requires removal of the drill string from the hole and attachment of the tool at the bottom of the drill string in an aluminum housing to avoid any magnetic interference from the steel drill string. Once lowered to the bottom of the hole, the tool records both inclination and azimuth every minute as the drill string is slowly pulled out of the hole. This produces regularly spaced survey data from which an accurate picture of the borehole can be created. 


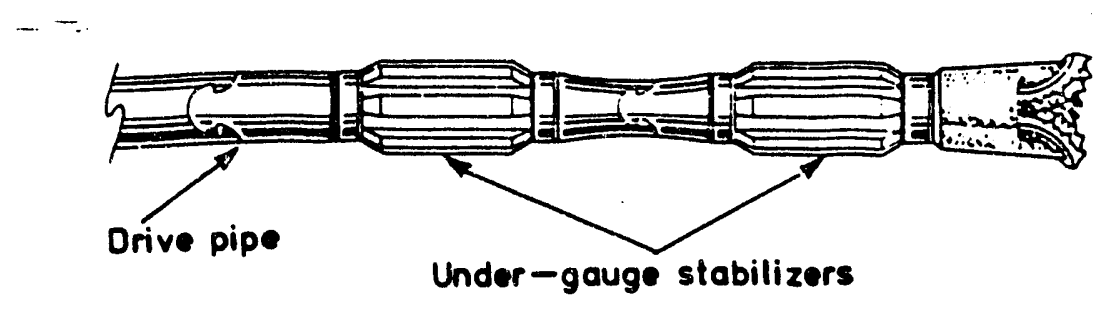

FIGURE 4.1.B. Rigid Drill Mandrel 


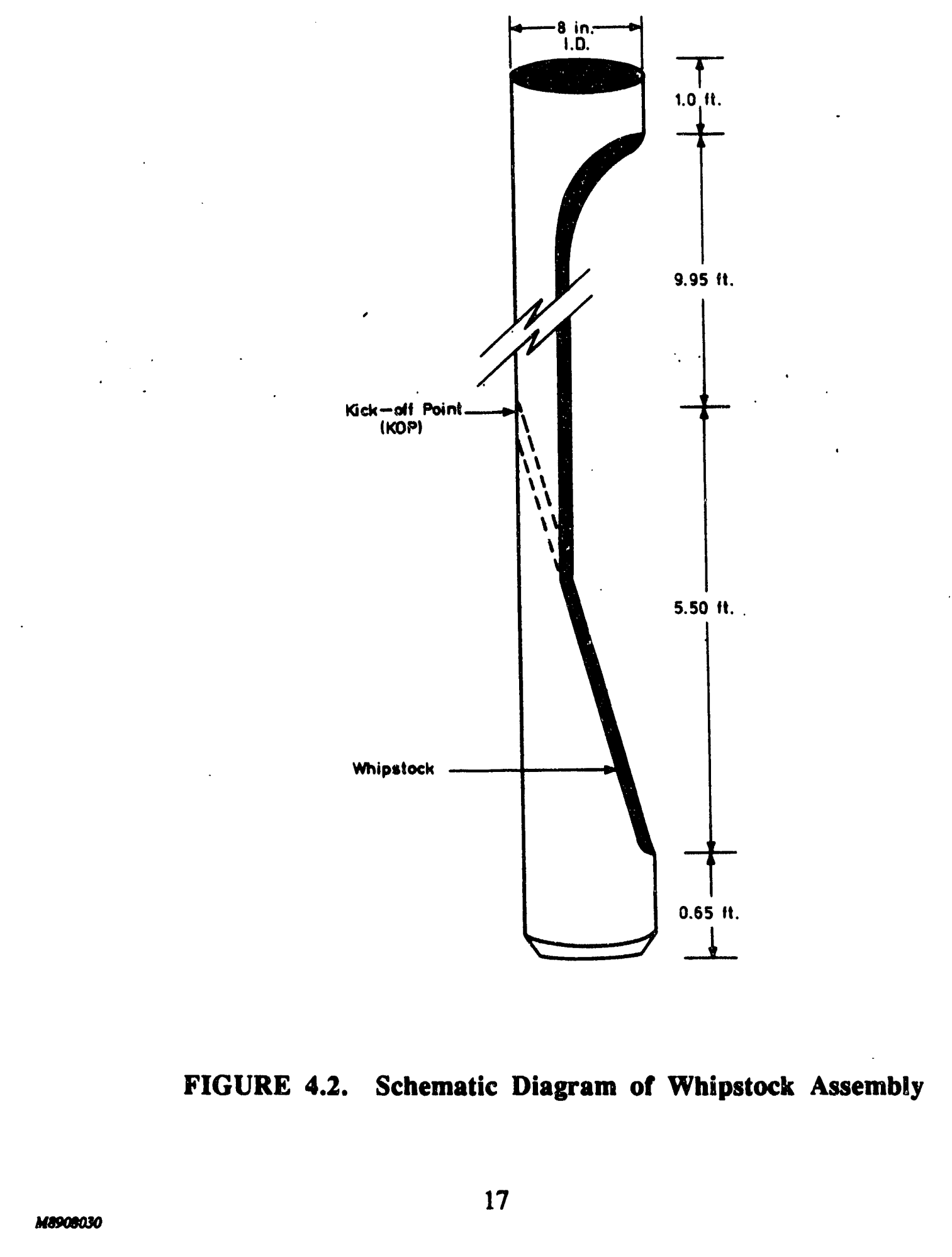




\subsection{TECHNICAL APPROACH}

Conoco Inc. was contracted for initial well design. The detailed well plans that were prepared prior to startup are included as Appendix C. Due to the research nature of the project and to complications that arose during the drilling, many of the original well-design specifications were modified as the project progressed. As-built well-construction specifications for each well are presented in Sections 6.1 and 6.2.

The technical approach for well design, drilling, and installation of the two wells was essentially the same. Target zones for the well laterals were selected using all available geologic, geophysical and water-quality data. The selections were based on the following criteria:

- Low fines content for greater permeability (maximum air and vapor flow)

- Coarse grain size for compatibility with screen slot size $(.010 \mathrm{~mm})$

- High concentrations of VOCs for maximum remediation (primarily for air-injection well AMH-1).

The original well plan called for drilling fluid consisting of only bentonite and water for the vertical sections of the borings with calcium carbonate and organic polymers added for the laterals. The lateral drilling was to be accomplished with a bentonite-polymer-fresh water system consisting of 23.8 pounds $/ 100$ gallons non-peptized bentonite powder, 208 pounds/100 gallons sized calcium carbonate (in sizes 5,50,150 and 600) and fresh water. The calcium carbonate was used to increase drilling fluid weight for greater hole stability and to provide a bridging material to minimize fluid loss. Partially hydrolyzed polyacrylamide (PHPA or EZ MUD) and organic polymers (QUICK-TROL) were to be added as needed to increase the strength of the filtercake and to aid in the suspension of drill cuttings. Maximum penetration rate for the laterals was designed to be 6 feet per minute at a circulation rate of 140 to 180 gallons per minute. High-viscosity "sweeps" consisting of 1 quart of PHPA were to be circulated following the completion of the holes to remove any remaining drill cuttings from the hole. In addition, a high-viscosity "pill" of bentonite, organic polymers, calcium carbonate and water was to be pumped into the hole and left in place to maintain hole stability while the drilling tools were removed, down-hole surveys were taken, and well materials were installed

The whipstocks for each hole were designed and built from 8-5/8-inch diameter steel casing according to Conoco specifications (Figure 4.2). They were welded to joints of standard 8-5/8-inch diameter steel casing, lowered into the 16-inch diameter boreholes to the desired depths and oriented in the desired direction. Kick-off points for the whipstocks were determined by subtracting the expected curve radius length from the targeted screen depth.

The open portion of the whipstock was tremie grouted with CAL-SEAL ${ }^{\mathrm{TM}}$, a quick setting calcium-sulphate based cement. This provided a relatively soft cement in which the curved drill guide could begin its drilling of the curve, decreasing the possibility of the bit shifting from its proper orientation during kickoff. After the CAL-SEAL ${ }^{\mathbf{M}}$ had cured for one hour, the remaining annular space was tremie grouted with a neat cement grout containing two percent calcium chloride as an accelerator to speed hardening. Grout was mixed with 5.2 gallons of water per 94 pound sack to produce an average weight of $15 \mathrm{lb}$./gal. The grout was allowed to set for at least eight hours to achieve a minimum compressive strength of $500 \mathrm{psi}$.

The CAL-SEAL ${ }^{\mathrm{TM}}$ was drilled out to the kick-off point using a 6-1/2 inch short-shank tricone bit (API 111) and standard 3-3/8 inch diameter drill pipe. The curve was then drilled using a 6-1/4-inch tricorie bit (API 111), the curved drill guide, and wiggly drive pipe. Down-hole single-shot surveys, recording inclination only, were taken at regular intervals during the drilling 
of the curve to insure that the proper angle build rate and curve radius were being achieved. Once the curve was completed, a magnetic multi-shot survey, recording both inclination and azimuth, was taken. To drill the lateral portions of the borings, the curved drill guide was removed; a rigid drill mandrel was placed at the end of the drive pipe. Single-shot surveys were taken at regular intervals to carefully monitor the lateral drilling performance. Once the lateral had been completed the rigid drill mandrel was removed and a magnetic multi-shot survey of the entire boring was taken.

The original well plan called for reaming of the hole before well materials were to be installed. Proposed completion materials consisted of 5-1/2 inch stainless steel, wire-wrapped 0.010 -inch screen with extra long welding rings, 5-1/2 inch $\mathrm{H}-40$ grade, 14-weight steel casing with an inflatable external casing packer (ECP) placed in the lateral portion of the borehole to seal off the lateral, and a rotary port collar (RPC) through which development fluid could circulate after the packer had been inflated. 


\subsection{WELL SUMMARIES}

This section presents separate discussions of the drilling and installation of each well. Included is a discussion of the major problems encountered and the corrective actions taken to insure that design objectives were achieved. The survey data are included in Appendix D and the casing tallies are included as Appendix E.

\subsection{AMH-1}

\subsubsection{Preliminary Work:}

A target zone of 151-157 feet below ground level was selected for the air-injection well (AMH-1). The kick-off point was determined by subtracting the anticipated radius of curvature ( 39 feet) from the center of the target zone (154 feet).

The original core hole was reamed to 195.0 feet with a 12.5 -inch diameter drag bit. The hole was reamed a second time to 189.0 feet with a 16 -inch diameter tricone roller bit to allow adequate room for the whipstock installation. Clean, fine, uniform silica sand was added to the hole via tremie pipe to 124 feet in order to fill the hole below the whipstock. The whipstock was welded to 121.81 feet of 8-5/8-inch diameter steel casing and lowered into the borehole with the kick-off point set at 115 feet below ground level.

The annular space around the whipstock was cemented with CAL-SEALme, a quick-setting calcium-sulfate cement, by the tremie method to 11 feet above the top of the whipstock ( 93 feet below ground level). The CAL-SEAL ${ }^{\mathrm{TM}}$ was mixed as 24 50-pound sacks to 115 gallons of water (4.8 $\mathrm{gal} / \mathrm{sack}$ ) to produce a final weight of $14.7 \mathrm{lb} . / \mathrm{gal}$. The top of the 8-5/8-inch diameter steel casing was sealed off to prevent CAL-SEAL ${ }^{\mathrm{mM}}$ from filling the inside of the casing. After one hour of curing time, 6.4 cubic yards of neat cement grout were tremied into the remaining annular space. The grout mix consisted of 16 94-pound sacks of cement per cubic yard and 2 percent calcium chloride as an accelerator to speed hardening. The mixture had an average weight of $15.4 \mathrm{lb} . / \mathrm{gal}$. The grout was allowed to cure for 40 hours while other work was performed. When drilling commenced, it was discovered that portions of the CAL-SEAL ${ }^{\mathrm{TM}}$ grout had not set properly. The hole was flushed with fresh water and re-grouted with 12 sacks of CAL-SEAL and 46 gallons of water, slightly less water than before.

\subsubsection{Drilling Performance}

The curve was drilled very slowly using high rates of rotation (60 rotations per minute) and low drilling-fluid flow rates ( $70-75$ gallons per minute) with a bentonite gel, Quick-Trol, calciumcarbonate drilling fluid of moderate viscosity (43 seconds) and high weight (9.4 lb./gal.). Penetration rates averaged approximately 1.5 to 2 feet per minute. The initial single-shot survey, taken 24 feet past the kick-off point, indicated an initial radius of curvature of approximately 33 feet, considerably smaller than the 39- to 40-foot radius anticipated. However, this degree of curvature was considered acceptable and no corrective action was taken.

Drilling-fluid circulation was 'nst to the formation as the bit neared 145 feet measured depth (MD) or 141 feet true vertical depth (TVD). An attempt to mitigate fluid loss was made by increasing the drilling fluid viscosity from 65 seconds to 180 seconds with almost no increase in fluid weight. Significant fluid loss continued with decreasing severity to approximately 170 feet $\mathrm{MD}$ as an adequate filtercake developed and the silt and clay content in the formation increased. A second survey, 40 feet past the kick-off point, indicated an increase in the radius of curvature to 36 feet. The curve was completed at 170 feet MD (150.5 feet TVD). 
The curved drill guide was removed from the hole and a magnetic multi-shot survey was taken of the entire curve. All directions are referenced to true north. A final angle of 88 degrees, 2 degrees below the horizontal, and an average radius of 35 feet was attained with an initial bearing of $\mathrm{N} 15 \mathrm{E}$. The intended direction had been approximately $\mathrm{N} 15 \mathrm{~W}$. However, it was decided that this bearing was within acceptable limits and drilling continued.

The lateral was drilled with the rigid drill mandrel, which consisted of a 6-1/4-inch tricone bit and two undersized stabilizers. Pumping rates were kept low (60-70 gallons per minute), as were rates of rotation (35-45 rotations per minute) and weight on the bit (2000-3000 pounds). Drilling fluid viscosity and weight were kept high (90-100 seconds and 9.0-9.1 lb/gal) to minimize fluid loss. Drilling proceeded extremely well as the hole progressed from 170 feet MD (150.6 feet TVD) to 250 feet MD (151.8feet TVD) with the lateral angle varying from 88 to 90 degrees. The ability to hold angle was greatly influenced by the 25 to 35 percent silt and clay matrix in the sands at this interval.

As the drilling passed 220 feet $\mathrm{MD}$ (152 feet TVD) the lateral drifted abruptly to the east, to a bearing of $\mathrm{N} 21 \mathrm{E}$. This eastward drift continued for the rest of the hole. Some hole instability was noted at approximately 240 feet MD (152 feet TVD) when the drill string met resistance while tripping into the hole. The blockage was removed by slowly rotating and washing the bit past this point. Below 250 feet MD (152 feet TVD) the lateral quickly lost angle, decreasing from 88 degrees to 85 , reflecting the marked decrease in silt and clay content of the formation. Drillingfluid flow rates were lowered to 72 gallons per minute and bit rotation was decreased to $35-45$ rotations per minute to minimize washout in front of the bit and create a greater build-rate.

At 300 feet MD (157 feet TVD) the bottom of the target zone had been reached, but the angle continued to drop. Further efforts to build angle were made by pulling the bit back and forth 3 to 5 feet with increased pumping rates to create a trough in the hole. This raised the front of the bit slightly and stopped the drop in angle, though no increase in angle was achieved.

By 380 feet MD (169 feet TVD), the lateral angle had decreased to 82 degrees and a final corrective action was taken. The drill string was tripped out of the hole and one of the stabilizers removed from the rigid drill mandrel, giving the bit the greatest possible build-rate. Pump rates were slowed even more to 66 gallons per minute, bit rotations were slowed to 35 rotations per minute and bit pressure was increased slightly. Drilling fluid viscosity remained high. Because this action constituted all possible methods known to produce angle building, the decision was made to finish the drilling with no further surveys. The hole reached a final measured depth of 485 feet. The drill string was removed; a magnetic multi-shot survey was taken of the entire hole. This survey indicated that the final corrective action,combined with increasing clay and silt content of the formation, corrected the angle drop and stabilized the bit path. Slight hole instability was noted again at 240 feet MD when the magnetic multishot survey tool had to be washed past an obstruction. Final bit angle was 92 degrees, 2 degrees above the horizontal, at a bearing of N 38 E.

The borehole was then enlarged to facilitate screen installation (5-1/2 inch stainless steel wirewrapped) by reaming with a special 7-7/8 inch wing bit. Hole enlargement was accomplished with penetration rates of 1 to 2 minutes per 10 feet of drilling. Drilling fluid viscosities were low (43 seconds); drilling fluid weights were moderate $(8.7 \mathrm{lb} / \mathrm{gal})$. Excessive fluid loss was noted at 283 feet MD (155 feet TVD). Drilling fluid viscosity was increased to 75 seconds and fluid weight was decreased in order to mitigate fluid loss to the formation. A high-viscosity "pill" of drilling fluid was used to sweep the borehole clean of excess cuttings and to maintain hole stability while the drill string was removed before screen installation.

Circulation was stopped for one hour while a final single-shot survey was taken to confirm alignment of the borehole after the hole enlargement. Following the survey it was discovered 
that the drill string had become stuck. It could not be determined whether the hole had partially collapsed, trapping the drill string, or whether the drill string had tecome stuck on the whipstock. Several actions were taken in an attempt to free the drill string from the hole. First, various combinations of turning, pushing, and pulling the drill string with extreme force, while circulating fluid, were tried with no success. The second attempt included thinning of the drilling fluid to minimize adhesion of the drill string to the borehole wall. Approximately 750 gallons of drilling fluid were lost to the formation during this second attempt. The third attempt consisted of using an 18-ton crane to assist the drilling rig in pulling the drill string from the hole, again without success. A final attempt, using only the drilling rig to pull, broke the drive pipe off in the hole just below the kick-off point, approximately 119 feet below ground level.

Oil-field tools especially designed to retrieve broken drill pipe were then used to attempt retrieval of the lost tools. Because this approach was not successful, 2-3/8-inch diameter EUE steel tubing with an open end was placed down the hole and drilling fluid was circulated in an attempt to free the drill string. The attempt to wash out formation material was unsuccessful. However, it was confirmed that the borehole was at least partially open throughout the entire length of the hole, because the 2-3/8 inch tubing was washed into the hole above the drill string and circulation was regained. The hole was fl:ıshed for 1 hour; then, a high viscosity (100 sec) and high-weight $(9.0 \mathrm{lb} / \mathrm{gal})$ fluid was pumped to the botton of the hole.

\subsubsection{Well Installation}

2-3/8-inch tubing, perforated with 1/8-inch diameter holes, was installed in the boring to salvage the hole and to complete it as an air-injection well. The desired length of tubing needed for screen (309.71 feet) was perforated with 5 pairs of 1/8-inch holes per 20-foot section before installation. The holes were drilled in pairs on opposite sides of the tubing (Figure 6.1). Each pair was rotated 900 from the other. The perforated tubing was installed entirely in the lateral portion of the borehole. Then, 121.77 feet of non-perforated 2-3/8-inch tubing and an inflatable casing packer were installed above the tubing. Approximately 7.0 feet of casing were attached to the top of the packer to bring the casing to the surface.

Well development included flushing the well initially with fresh water and then with a mixture of sndium hexametaphosphate and water to break down the filtercake on the borehole walls, thus promoting air-injection into the formation. The well was completed with a well-head seal and concrete pad at the ground surface.

\subsection{AMH-2}

\subsubsection{Introduction}

The target zone for AMH-2 was above the water table at a depth of 65 to 75 feet below ground level. This interval possesses the best permeability for vapor flow in the unsaturated zone.

Five attempts made to drill and install the second well, AMH-2. Problems encountered included hole stability, excessively rigid well materials, and movement of the curved drill guide while drilling the curve. Each successive effort provided additional information about the behavior of drilling in unconsolidated sediments and about the requirements of well materials for successful installation. The same basic equipment used for AMH-1 was used for AMH-2. 


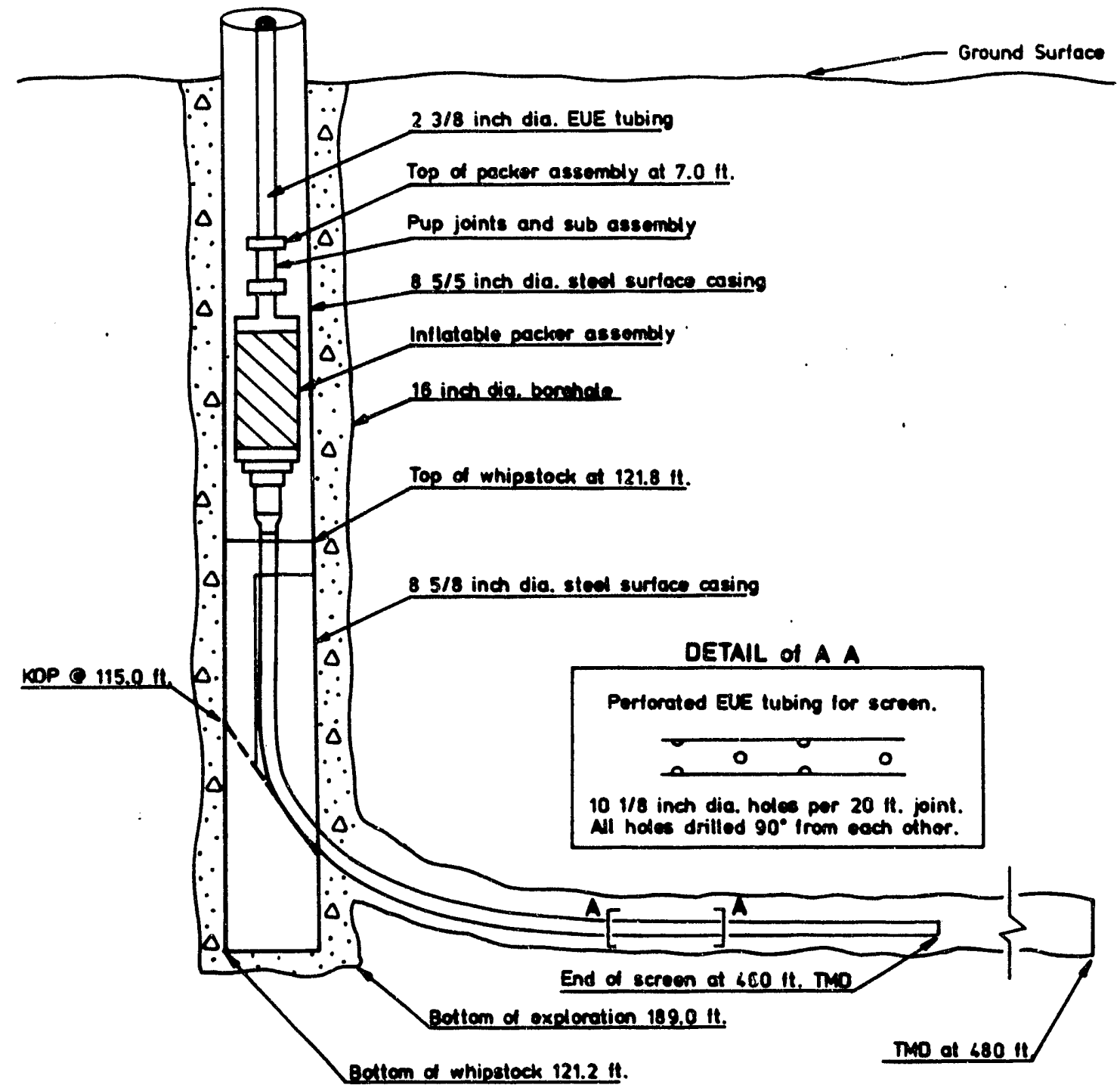

FIGURE 6.1 AMH-1 Well Construction Diagram 
However, some of the materials in the mud system were changed to improve hole stability. Lignite and polymers ( $E-Z$ mud ${ }^{\mathrm{TM}}$ ) were added to the mud program to increase viscosity, decrease weight, and enhance filtercake formation on the borehole wall. The drilling program was also altered based upon information obtained during drilling of $\mathrm{AMH}-1$. Slower penetration rates and rotation rates were used to increase hole stability.

\subsubsection{Drilling Performance: First Attempt}

The first hole drilled for AMH-2 was located approximately 40 feet north of AMH-1 and 15 feet west of the process sewer line. Although the initial drilling plan called for the second well to be drilled 350 feet north of AMH-1 in a southerly direction, it was decided to alter the location to avoid unnecessary mobilization costs. Because the whipstock for AMH-2 had already been installed in the northern location, the first attempt to drill $\mathrm{AMH}-2$ was made without using a whipstock. A 16-inch diameter hole was reamed to a depth of 45 feet below ground level. The kick-off of the curved drill guide was attempted by (1) orienting the curved drill guide as it was lowered into the hole and (2) drilling with low bit speed (28 to 30 rotations per minute), low bit weight (the weight of the drill string) and slow rates of penetration (approximately 1 foot $/ 5$ minutes). The objective was to allow the curved drill guide to utilize its inherent curvature to initiate the curve, rather than using a whipstock. The curve was drilled in this manner to a measured depth of $\mathbf{4 5}$ feet; a magnetic multi-shot survey was then taken to confirm the alignment of the curve. The survey showed that the curved drill guide had rotated approximately 180 degrees from the original alignment. This deviation was unacceptable and the hole was grouted closed.

\subsubsection{Drilling Performance: Second Attempt}

The second attempt to drill AMH-2 was made by drilling a 6-3/4 inch hole through the grout of the same borehole and installing a standard, retrievable whipstock mounted on an inflatable casing packer. If successful, this approach would add potential savings for future borings because the whipstock could be used multiple times. The whipstock and casing packer were installed in the hole at the desired depth and the packer was inflated. The pressure to the packer was raised to 200 psi and maintained for 1 minute. The pressure was then increased to 400 psi, at which point the rubber packer-inflation element ruptured due to the insufficient confining strength of the grout column. The packer and whipstock were removed from the hole and the hole was grouted closed. The inflatable packer requires a more competent geologic column to be successfully used.

\subsubsection{Drilling Performance: Third Attempt}

The whipstock was retrieved from its original proposed location by washing over the whipstock with larger casing. It was then installed 10 feet southeast of the first two attempts. The whipstock was grouted into a 16-inch diameter hole that was reamed to a depth of 35 feet. The kick-off point was set at 25 feet below ground level with an orientation of approximately due north.

The curve was drilled to a measured depth of 59 feet (29 feet past the kick-off point); a singleshot survey was taken. The survey indicated a radius of curvature of $30 \mathrm{feet}$, smaller than expected. The curved drill guide was then worked back and forth in the curve with high rates of drilling fluid circulation in an attempt to wear down the outside of the curve, thus increasing the radius of curvature. An additional 20 feet was drilled; a second single-shot survey was taken. This survey indicated no increase in the radius of curvature. The curved drill guide was then removed; eight feet of the curve were drilled using an 8-1/2 inch bit and flexible drive pipe to create a short tangent in the curve, thus forcing the curved drill guide to a larger radius of curvature. The curved drill guide was then re-inserted into the hole and used to complete the curve. The magnetic 
multi-shot survey taken at the end of the curve indicated that this technique had been successful. The final radius of curvature was slightly greater than 35 feet with an orientation of $\mathrm{N} 4 \mathrm{~W}$ and a final angle of 2 degrees below the horizontal.

The lateral was drilled with relatively high bit speeds (60 to 80 rotations per minute), high bit weights of 2000 to 3000 pounds, high fluid pumping rates (90 to 112 gallons per minute) and with a drilling fluid of moderate viscosity ( 42 to 43 seconds) and weight ( 8.5 to $8.8 \mathrm{lb}$./gal.). Lateral angle held to within three degrees of horizontal; azimuth remained within two degrees of the bearing at the end of the curve. No major fluid losses were observed. For the initial portion of the lateral, total vertical depth ranged from 60.1 to 64.1 feet below ground level. At 180 to 190 feet MD the angle was observed to drop from 87 degrees to 83 degrees and the azimuth drifted from $\mathrm{N}$ $4 \mathrm{~W}$ to due north over a 10 to 20 foot interval. This change in direction and angle matches fairly closely with a change in lithology at 64.5 feet TVD from a fine-to medium-grained sand with 20 to 30 percent fines to a less competent medium-to coarse-grained sand with only 5 to 10 percent fines. Fluid pumping rates and bit speeds were decreased and the weight on the bit was increased to help hold and build angle in the less competent material. The lateral was completed to a final depth of 281 feet MD (75.14 feet TVD), just at the bottom of the proposed target zone.

The magnetic multi-shot survey tool was placed down the hole, but could not be inserted past 220 feet MD, even when using considerable torque and down pressure. Some hole instability was also noted at 120 feet MD (60 feet TVD) when the magnetic multishot survey tool had to be washed past an obstruction. The orientation of the lateral at 220 feet MD was determined to be $\mathrm{N} 2 \mathrm{~W}$ (very close to the target direction) at an angle of $\mathbf{8 3 . 5}$ degrees. Following the survey, the hole was reamed with a 7-7/8 inch hole-opener bit to ensure an open borehole for the entire lateral length and to provide adequate room for the installation of well materials (5-1/2 inch diameter screen). Hole direction and depth were very close to that proposed.

\subsubsection{Well Installation: First Attempt}

Initial attempts to install 5-1/2 inch diameter stainless-steel screen proved unsuccessful. A float shoe, or modified check valve, at the bottom of the screen was placed at a 5-degree upward angle in order to help the screen through the curve. The screen was installed to 66.87 feet (approximately $\mathbf{4 2}$ feet past the kick-off point), at which point it could not be advanced further, even when using as much as 1750 psi of downward gauge pressure (approximately 80,000 lbs. of force). Circulation was established through the float shoe and repeated attemnts to advance the screen were unsuccessful. The 5-1/2 inch screen was removed from the jie and 2-3/8 inch diameter stainless-steel wire-wrapped screen was purchased.

One hundred seventy feet of 2-3/8 inch diameter screen were installed by hand with little or no resistance. A crossover sub (11.95-feet long) was attached to the top of the screen to allow the installation of the original packer with the smaller screen. 5-1/2 inch steel casing was attached above the packer. However, the crossover sub was too rigid to negotiate the curve and broke off just above the screen, approximately 29 feet below the kick-off point. All attempts to recover the well screen were unsuccessfull. The hole and screen were abandoned by grouting the borehole with cement.

\subsubsection{Drilling Performance: Fourth Attempt}

Because of the success of the drilling of the last lateral and the lessons learned from the attempted well installation, a fourth attempt was made to drill and install AMH-2. The whipstock was recovered from the previous boring and re-installed approximately 12 feet to the north and 10 feet to the east of the previous boring. The whipstock was installed with an orientation of $\mathrm{N} 5 \mathrm{~W}$ with 
the kick-off point set at 34 feet below ground level. The kick-off point was set slightly lower than in the last boring due to the small radii of curvature achieved in the previous borings.

The curve was drilled with light bit weight ( 500 pounds), slow bit speeds ( 34 to 40 rotations per minute) and moderate drilling fluid flow rates (60 to 66 gallons per minute). The drilling fluid was maintained consistently at a viscosity of 34 seconds and a weight of 8.0 to $8.6 \mathrm{lb} . / \mathrm{gal}$. The curve was completed with (1) no complications, (2) a radius of curvature of 38 feet, (3) a final orientation of N 12 E, and (4) an angle of 87.5 degrees at a TVD of 70.0 feet below ground level.

The lateral was drilled in a manner similar to that of the previous boring with bit weights of 2000 to 3000 pounds. However, slightly lower bit speeds (36 to 45 rotations per minute) and drilling fluid flow rates were used because the formation at this depth was less competent than the shallower interval encountered during the last attempt. Drilling proceeded well until 100 feet $\mathrm{MD}$ when the angle began to drop slightly. The angle dropped continuously from 87 degrees to as low as 78.5 degrees at the end of the lateral. Bit speeds were lowered to 25 to 35 rotations per minute in order to hold and build angle. However, all attempts to correct the angle proved unsuccessful. As the bit descended, losing roughly 0.16 feet per foot of lateral drilled, the lateral orientation also drifted to the east. From 160 feet MD (77.6 feet TVD) to the end of the lateral at 290 feet MD (100.7 feet TVD) the bit orientation gradually drifted from N $11 \mathrm{E}$ to $\mathrm{N} 25 \mathrm{E}$. This repeated the pattern of the bit drifting to the right (east) and dropping angle in the unconsolidated, loose sands observed during the drilling of the previous laterals, especially AMH-1. Minor hole instability was noted at 140 feet MD when pulling the bit out of the hole after reaching TD. However, no instability was observed while taking the magnetic multishot survey shortly thereafter.

After the lateral was completed to a total measured depth of 290 feet, a 7-7/8 inch hole opener was used to ream and flush the lateral. However, while reaming the curve, the hole-opener bit left the path of the curve at 55 feet MD (21 feet below the kick-off point) and created a new hole. Subsequent attempts to re-establish a path to the lateral borehole proved unsuccessful; a decision was made to abandon this boring and begin again.

\subsubsection{Drilling Performance: Fifth Attempt}

The final attempt was made approximately 54 feet north and 63 feet east of AMH-1 and 26 feet east of the abandoned process sewer line (see Figure 2.2). The whipstock was again retrieved from the previous boring and installed in the new location in the same manner as described previously. The kick-off point was set at 25 feet, slightly higher than before, with an orientation of $N 5 \mathrm{~W}$. The KOP was raised in order to improve drilling performance by drilling in a slightly more competent formation and yet remain within the target zone.

The curve was drilled with 750 to 1200 pounds of weight on the bit, slow bit speed (29 to 30 rotations per minute) and slow drilling fluid flow rates ( 36 to 45 gallons per minute). Drilling fluid viscosity was maintained at 42 seconds with a moderate weight of $8.5 \mathrm{lbs} / \mathrm{gal}$. The curve was drilled relatively quickly with no complications. An initial magnetic multi-shot survey of the curve indicated (1) a radius of curvature of 36 feet, (2) an orientation of $N 12 \mathrm{~W}$, and (3) a final angle of
87.5 degrees. The end of the curve was at 61.5 feet TVD at the top of the target zone.

The rigid drill mandrel with the 6-1/2 inch bit was inserted to drill the lateral. The lateral was drilled from the end of the curve to 122 feet MD (1) with an increased bit weight of 2000 to 3000 pounds, (2) with bit speeds similar to those used for the curve, and (3) with moderate fluid pumping rates $(50 \mathrm{gpm})$. Initial single-shot surveys indicated that the angle was holding relatively well, dropping only one-half degree to 87 degrees with no drift in orientation. Drilling bit speeds were reduced to 25 to 35 rotations per minute over the next 60 feet to maintain and increase angle. 
By 143 feet $\mathrm{MD}$, however, the angle had dropped to 86.5 degrees. At this time the rigid drill mandrel was retrieved from the hole and the rear stabilizer was removed to give the bit maximum MD (67.7 feet TVD) the anglewever, this action did not change the angle build-rate; at 180 feet slightly to the east. All additional measures 84 degrees and the orientation of the bit had drifted lateral at 280 feet MD were unsuccessful.

At 220 to 230 feet MD (72.3 to 73.5 feet TVD) the bit drifted rapidly to the east to an orientation of $\mathrm{N} 1 \mathrm{~W}$ with no marked change in the rate of angle drop. This depth roughly corresponds to a contact between a sand with 15 to 25 percent fines and a loose sand with 5 to 15 percent fines. The lateral was completed to a final measured depth of 283 feet ( 78.5 feet TVD) with a final angle of 83.5 degrees and an orientation of $\mathrm{N} 4 \mathrm{~W}$. Direction and depth of the hole were very close to
that originally targeted.

The hole was not reamed with the hole opener bit to minimize disturbance of the borehole. The only change in the drilling procedure was the addition of two wiper passes after each drill collar not be sanded in place. The drilling to flush sand out the hole to insure that the drill rod would between $1500-1700$ psig, (2) bit rotation mud specifications for this hole were: (1) bit weight $8.7 \mathrm{lb} / \mathrm{gal}$ weight.

\subsubsection{Well Installation: AMH-2}

Four and one-half inch diameter stainless-steel wire-wrapped screen was selected as the optimum for well completion. This screen provided greater flexibility than the 5-1/2 inch screens, yet more strength and surface area than the 2-3/8 inch screens. Screen was installed through the curve to the vertical portion of the bore-hole because of the limited flexibility casing packers or equivalent. Two cement baskets, instead of casing packers, were attached to the casing above the screen (see
Figure 6.2).

To improve screen installation techniques, a 5-foot section of flexible drive pipe was attached to the float shoe at the leading end of the screen to help the screen follow the curve and guide it through the lateral portions of the borehole. Screen installation proceeded easily with maximum downward gauge pressures of only 850 psi to advance the screen. At 232 feet the screen met with firm resistance and would not advance further. This depth corresponded to the portion of the lateral where loose sands occurred and the hole orientation turned to the right. Two 20-foot joints of cement baskets were and 21.12 feet of 4-1/2 inch diameter steel casing with a centralizer and two 13.9 feet below the top of the casing screen. The cement baskets were attached at 11.4 and 204.7 feet of $4-1 / 2$ inch diameter stain, just above the window in the whipstock. A total of 21.12 feet of $4-1 / 2$ inch diameter steeless steel wire-wrapped screen with 0.010 inch slots and well screen and sther performed by inserting 2-3/8 inch diameter fiberglass tubing through the through the bottom of the screen. drilling fluid. Two hundred pounds of sodwas initially flushed with fresh water to remove excess of fresh water. The mixture was co sodium hexametaphosphate were mixed with 4000 gallons filtercake that had built up on the borehole through the borehole to break down and dissolve the jetting head, consisting of a 2 -foot longle walls. The fiberglass tubing was then removed and a tubing. The tubing and jetting head pounds of sodium hexametaphoad were inserted to the bottom of the screen; a mixture of 500 pressure through the jetting head. residual drill cuttings and to remove entire screen length was jetted to clean the screen slots of 


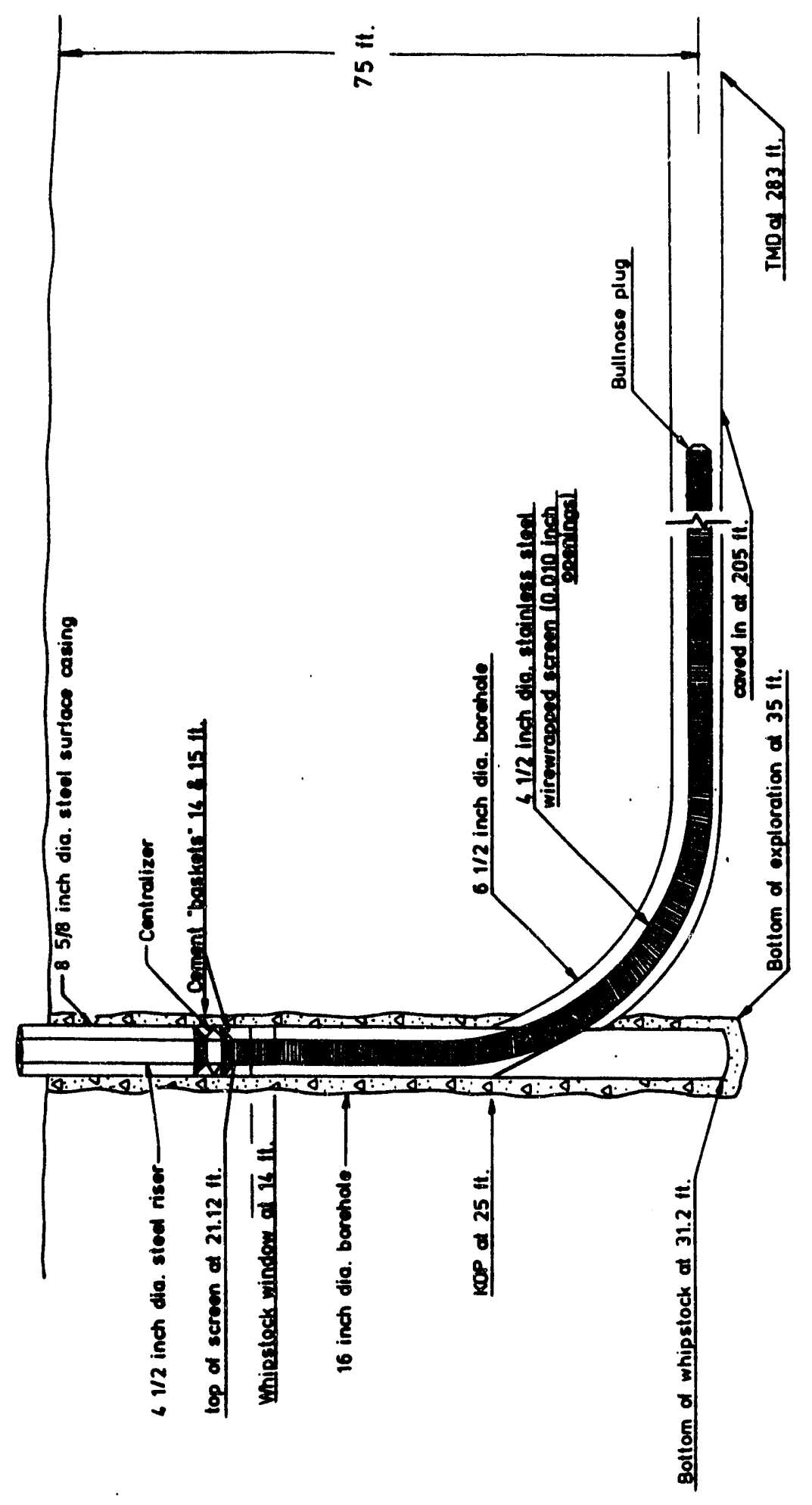

FIGURE 6.2. AMH-2 Well Construction Diagram 
had been jetted, the filtercake had broken down sufficiently so that the formation was readily accepting the development solution. None of the development solution was returned to the surface. Well development was completed by jetting the remainder of the screen in the same manner despite the lack of returns at the surface.

The well was sealed by placing 1.5 cubic feet of $1 / 4$-inch bentonite pellets in the top cement basket and allowing the pellets to hydrate for several hours. A cement grout was later installed above the bentonite seal to ensure an adequate permanent seal. The well was completed by installing a wellhead at the surface and by constructing a concrete pad around the base of the well-head.

Figures 6.3 and 6.4 show cross-sectional and plan views of the boring alignment generated from the original survey data, which are included in Appendix D. 

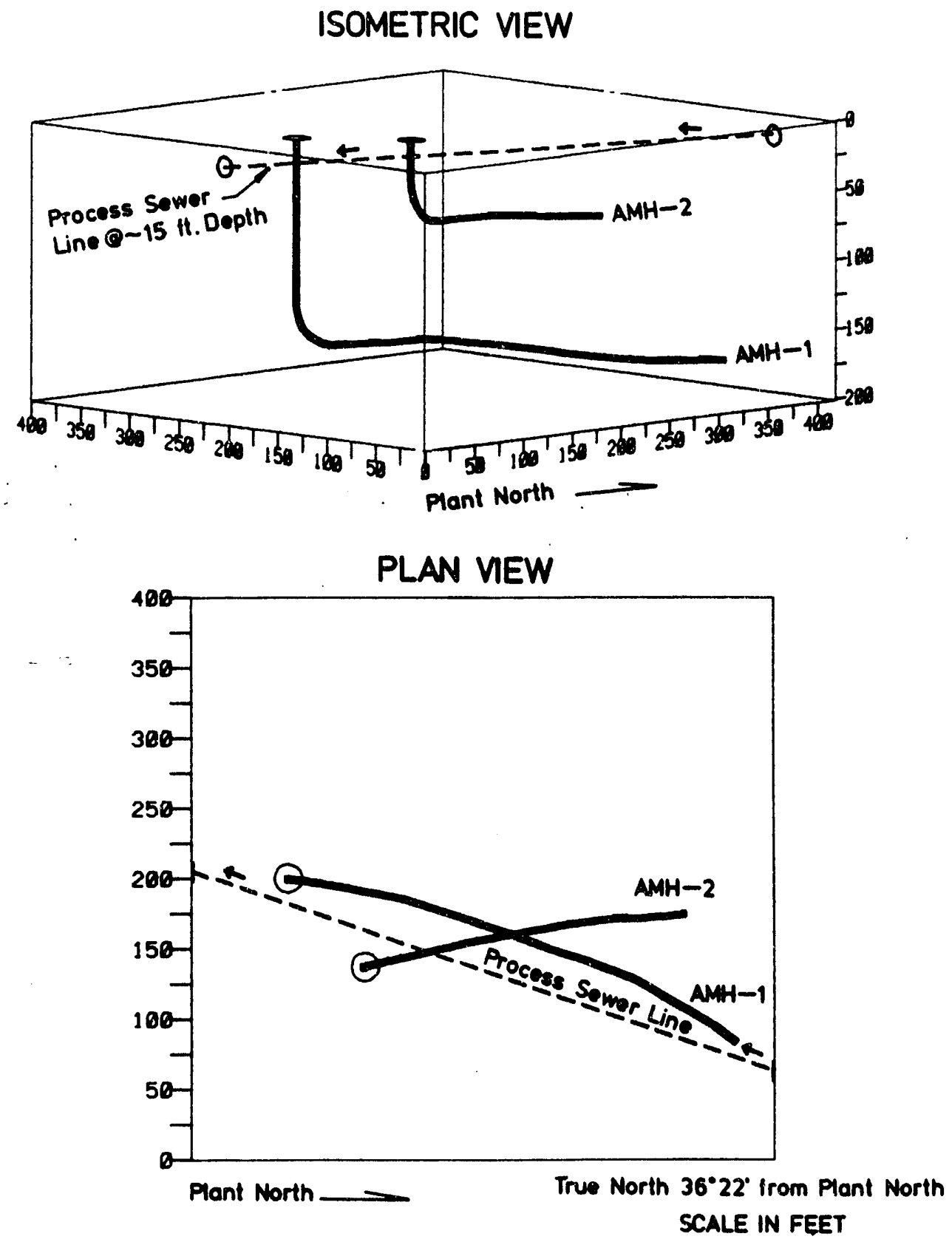

FIGURE 6.3. Isometric and Plan View of Final AMH-1 and AMH-2 Boring Alignments 


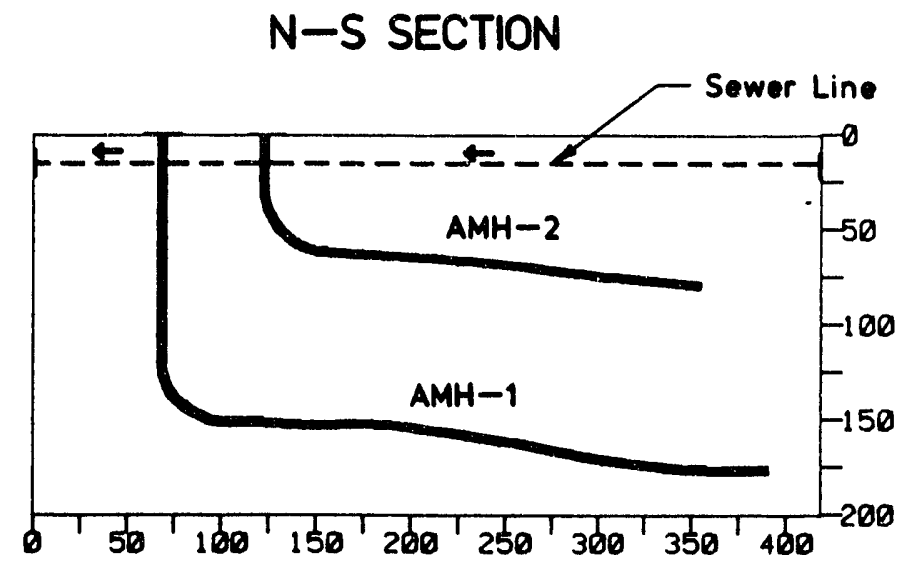

Plant North

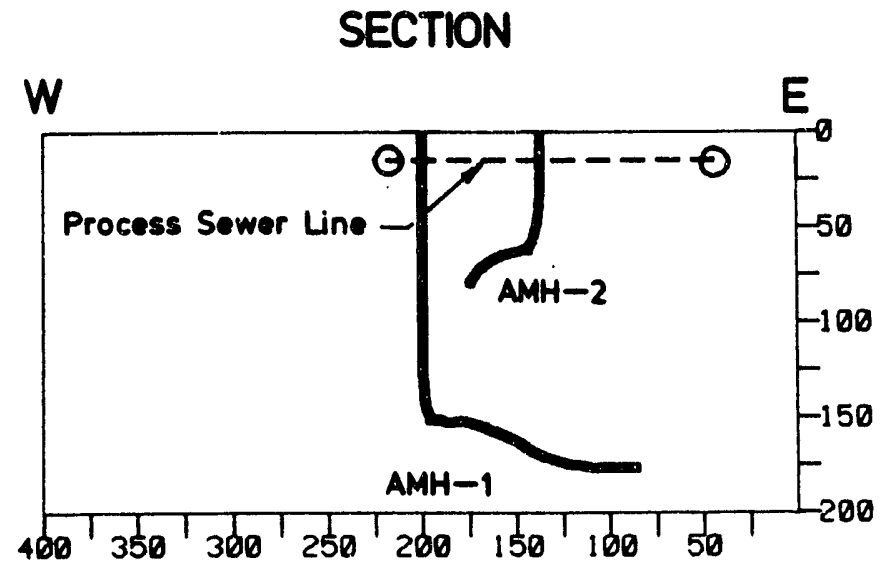

(True North $36^{\circ} 22^{\circ}$ from Plant North) SCALE IN FEET

FIGURE 6.4. Cross Sectional Views of Final AMH-1 and AMH-2 Boring Alignments 


\subsection{DISCUSSION}

Due to the experimental nature of this project, several modifications to the original drilling and well design specifications were necessary. The horizontal well technology had been applied only in consolidated sediments. Unfamiliarity with the application of this technology in relatively shallow unconsolidated sands necessitated adjustments throughout the program. The geologic conditions required special drilling fluid, drilling techniques, and well design. The following sections describe the factors that influenced the successful drilling and well installation.

\subsection{Analysis of Drilling Program}

Changes in the drilling program were made in the field in response to site-specific conditions in an effort to (1) minimize perturbation to the formation, (2) minimize fluid loss, (3) maximize curve and lateral drilling performance, and (4) facilitate well installation.

Overall drilling performance was controlled by several factors including:

- Specific geologic conditions (percentage of fines)

- Rigid drill mandrel configurations

- Drill bit speed and weight

- Drilling fluid pumping rates.

Geologic conditions had the greatest effect on drilling performance. In lithologies that possessed greater than 15 to 20 percent fines, the bit was observed to maintain azimuth and hold or even build angle. Minimal fluid loss to the formation and greater hole stability in the curves and laterals were also observed in these lithologies. However, in sandy lithologies with less than 10 to 15 percent fines, the ability to hold angle and maintain azimuth was greatly diminished. Figure 7.1 overlays the two horizontal wells on the geologic cross-section.

Lower penetration rates and lower bit-rotation rates allowed the drilling fluid time to circulate the drill cuttings from the hole. Slower drilling rates reduced stress on fragile unconsolidated sediments due to shearing action on bit and drill collars. Drag on the bit and drill collars was also reduced, thus decreasing the torque and pressure on the drill rig. This had the advantage of not only increasing hole stability but reducing the number of equipment breakdowns.

The primary change in the drilling program was the removal of the reaming step to enlarge the borehole curve and lateral. Reaming of the hole removed the established filtercake on the borehole walls, which in turn decreased hole stability, especially in the less cohesive sediments of the target zones. In addition, the hole-opener bit has the potential to deviate from the existing borehole path, as observed in one of the attempts to ream AMH-2.

Tripping in and out of the borehole was kept to a minimum. The primary concern is reduction of "wear and tear" on the curve. This not only causes problems in drilling, but may produce an irregular curve, which jeopardizes well-screen installation.

A soft, calcium-sulphate based cement (CAL-SEAL ${ }^{\mathrm{TM}}$ ) was not necessary for the successful kickoff and drilling of the curves. Once a 6-3/4 inch pilot hole was drilled down through the cement to the kick-off point, the curved drill guide consistently drilled the curve with no complications. No excessive rotation of the curved drill guide from its initial alignment was observed. One-step cement grouting of the whipstocks speeded up installation by eliminating additional mixing and curing time. 


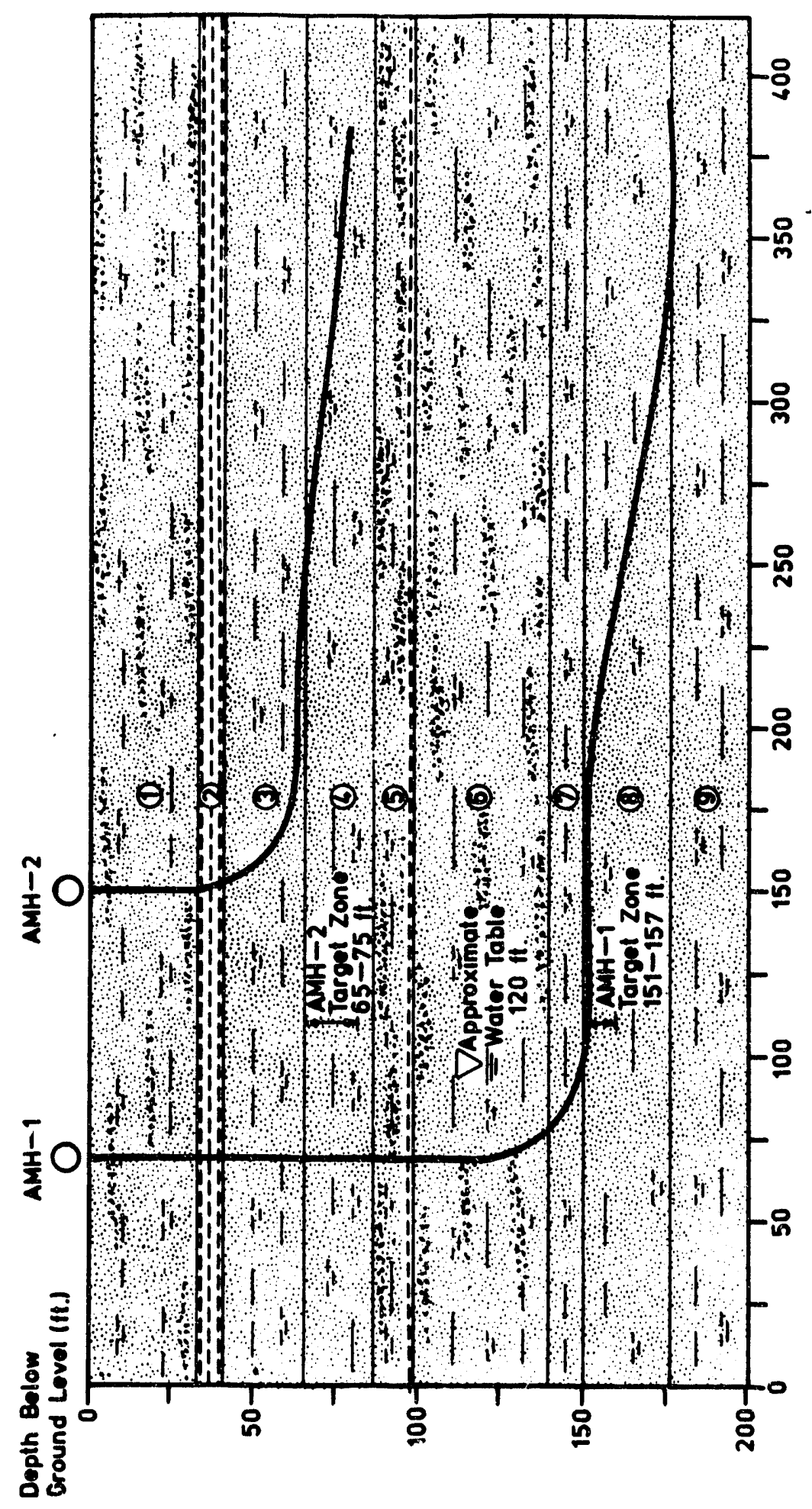

FIGURE 7.1. Cross Section of Both Horizontal Wells 
Close inspection of the final well magnetic multi-shot surveys, geologic logs and geophysical logs demonstrates the tendency of the lateral drilling tools to lose angle and drift to the right (the direction of bit rotation) when making the transition to strata with differing percent fines (cohesive
strengths). The drop in angle is interpret tendency of the drilling tools to drift in the to be the result of wash-out in front of the bit. The In loose, clean sands, torque may cause uneven sedion bit rotation is probably caused by torque. side of the bit; this results in drift to the right. Changent abrasion, which is greater on the right right often occurred together, though occight. Changes in angle and the tendency to drift to the Some of the more obvious and abrupt occasionally the two actions would occur independently. conditions can be seen in Figures 6.3 and 6.4 (ref azimuth and angle in response to subsurface detailed geologic data along the entire lateral would plan and cross section views). More regarding the interaction between the drilling tools and the needed to draw further conclusions

In addition to zeologic conditions, specific drilling parameters such as bit speed, weight on the bit, bit and drill:- fluid circulation, and configuration of the rigid drill mandrel affected the angle of the borehole face performance. Maintaining the upward orientation of the bit with respect to the decreased the abrasion for building angle. Slower bit speeds (25 to 50 rotations per minute) mandrel a greater angle of attack the bit. This gave the bit and rigid drill washing out of sediments directly in borehole face. Slower fluid pumping rates minimized the orientation. Increased bit weight also front of the bit, allowing the bit to maintain a more upward borehole face the bit becomes cocked slightly aid in angle building. By forcing the bit into the front of the bit.

The rigid drill mandrel discussed in section 4.0 was initially configured with two near-bit stabilizers: a 6-inch diameter stabilizer directly behind the bit and a 6-1/4-inch stabilizer between the first stabilizer and the drill string. This configuration was designed to give a fairly progressive sufficient, so the rear stabilizer $/ 100$ feet). However, in some instances this build rate was not configuration generated the maximum was removed, tilting the bit upward even more. This hold angle. Various combinations of possible built rate and was used as a last resort to build or and increase or hold lateral angle when drilling in the parameters were used to maintain orientation

\subsection{Analysis of Drilling Fluid Program}

The drilling fluid program for drilling of the horizontal wells was crucial to the success of the project. Drilling fluid and solids control were essential for maintaining borehole stability and drilling mud must be able to hole, due to the highly unconsolidated nature of the sediments. The (2) remove solids and fines. Wallcake is essential around the perimeter of the borehole quickly and the borehole and preventing fluid from migrating into or out of the borehole.

The original drilling fluid formulation discussed in Section 5.0, was utilized for the drilling of AMH-1. Overall, the drilling fluid used for AMH-1 worked fairly well. However, some hole 35 percent fines and sands with less than feet TVD), at a contact between sands containing 25 to when removing the drill string after reaching percent silt and clay. This instability was observed survey tool prior to reaming.

Also, excessive fluid loss was observed near 283 feet MD (155 feet TVD). This depth corresponds to the interval of clean sand mentioned above. The high specific weight of the drilling fluid formulation (8.9 to 10.1 pounds/gallon) created high hydrostatic pressures, which helped difficulty providing fluid lighly permeable sections of the formation. Thus, this drilling fluid had difficulty providing fluid loss control and hole stability in the cleanest, mechanically weak sands. 
Although the well for AMH-1 was successfully completed, the loss of the drill string and fluid loss problems prompted changes in drilling fluid formulations. Bentonite powder, lignosulfonate, drilling soap and water were used with organic polymers to create a lower weight drilling fluid with better flow characteristics and similar fluid-loss prevention qualities. The lignosulfonate provided enhanced filtercake formation with minimal weight increase. The drilling soap was added to increase the lubricity of the fluid, which improved flow characteristics in the borehole. The bentonite and organic polymers were used, as before, to provide viscosity, gel-strength and strong filtercake development. The exact proportions for this fluid formulation varied as the mud engineer monitored drilling progress and quality of drilling fluid returns. Overall, the drilling fluid was maintained at a weight of 8.0 to $9.0 \mathrm{lbs}$./gal. and a funnel viscosity of 35 to 60 seconds. Viscosities were increased to 70 to 90 seconds when drilling highly permeable zones. Organic polymers were added to increase viscosity with little or no increase in fluid weight. Viscous sweeps and pilis were performed as outlined in the original drilling program.

Several hole instabilities were noted for wells $A M H-2 C, A M H-2 D$ and AMH-2E, using the new drilling fluid formulation. However, no major fluid losses occurred. In AMH-2C, one tight spot at 120 feet MD (61 feet TVD) was noted when tripping in the magnetic multishot survey tool and when reaming the hole with the hole-opener bit. The tools were easily washed past the obstructions. Two and three-eighths inch screen was later set entirely by hand with no major blockages, indicating an open borehole with good hole stability. However, due to other complications, this hole was abandoned.

Minor borehole instability was noted at 140 feet MD (74-75 feet TVD) while drilling AMH-2D. This depth corresponds to a well-sorted sand with 10 to 15 percent fines. Howeve:; no instability at that location was noted, when the magnetic multishot survey tool was lowered into the hole. During an attempt to set 4-1/2 inch screen in this hole extreme resistance was encountered at 55 feet MD (53 to 54 feet TVD). This resistance may have been due to collapse of loose sands in the curve at a contact between loose sands with 5 to 10 percent fines and sands with 10 to 20 percent fines or due to a nosing of the screen into the outside wall of the curve. Following the installation attempt, an effort was made to clear the hole with the holeopener bit. The bit left the path of the curve exactly where the screen met with resistance.

The only hole stability problem encountered in AMH-2E was at a measured depth of 232 to 285 feet (70 to 76 feet TVD). The strata at this depth are characterized by loose, well-sorted sands with 5 to 15 percent fines. During the ten-hour period that extended from the termination of fluid circulation to the installation of screen, a portion of the borehole collapsed at 285 feet MD. This hole instability may have been due, in part, to the relatively low fines content of the formation as well as the length of time the borehole was left uncirculated. The bottom 53 feet of the hole were lost; the screen was successfully installed to a measured depth of 232 feet.

Comparison of drilling fluid performance for the two formulations is difficult for several reasons. First, the fluid systems were used to drill different geologic intervals. Each interval contained sands of different grainsize distribution, sorting, grain angularity, fines content, and water content. Direct comparison between the two drilling fluid formulations must, therefore, be made with caution. Secondly, it was not possible to run caliper logs to determine exactly how well the fluid systems maintained hole stability. Hole stability was evaluated primarily on difficulty encountered while running drill pipe, survey tools, and well materials in the hole. Thirdly, hole stability was influenced by specific drilling parameters such as fluid pumping rate, bit weight, bit rotation speed, and penetration rates. Because these drilling tools had never been used under these geologic. conditions, drilling techniques and parameters were varied considerably from hole to hole to improve overall drilling performance. The initial drilling fluid formulation was used in fully saturated conditions below the water table, whereas the second fluid formulation : $:$ as used in unsaturated conditions. Because the structural characteristics of the sediments are greatly 
influenced by their water content, evaluation of the fluids' abilities to maintain hole stability and fluid loss control is complicated. Overall, each formulation had pros and cons; and neither formulation can be said to have been better than the other.

Because geologic conditions vary significantly from site to site it is strongly recommended that an experienced mud erigineer be retained for drilling fluid program design and implementation. The mud engineer should consult with project geologists and the drilling contractor who should be familiar with specific geologic conditions of the site.

The following summary outlines the advantages and disadvantages of each fluid formulation.

\section{Bentonite-Polvmer-Water-Calcium Carbonate Formulation}

1) Advantages:

- No dispersion of formation clays, thus increasing hole stability

- Fluid loss control by actual bridging of pores in borehole wall in addition to filtercake development

2) Disadvantages:

- High fluid weights required for fluid loss control in highiy permeable, coarse-grained material can force fluid's into the formation, limiting the fluid's efrectiveness

\section{Bentonite - Polymer - Water-Lienosulfonate-Soap Formulation}

\section{1) Advantages:}

- Enhances filtercake development; lignosulfonate disperses the bentonite clays, allowing the clay platelets to lie flatly along the borehole wall; this increases the effectiveness and strength of the filtercake

- The drilling soap reduces fluid-flow friction at the borehole wall, improving one fluidflow characteristics

- Decreases potential for clay swelling; the lignosulfonate acts as a surfactant inhibiting the swelling of formation clays.

2) Disadvantages:

- Dispersion of clays by lignosulfonate may also disperse formation clays, thus clecreasing the overall streagth of the formation; however, once the filtercake has been well established the formation is isolated from the surfactant in the drilling fluid.

\subsection{Analysis of Well Design}

Well designs were changed significantly from those originally proposed. Because the drilling tools were left in the boring for AMH-1, original well design could not be completed. Flexible 2-3/8 inch diameter EUE steel tubing with regularly spaced perforations was installed with an inflatable casing packer placed in the casing of the vertical portion of the hole.This well design meets the requirements for air injection. 
Attempts to install the originally specified well materials in the borings for AMH-2 met with considerable difficulty. The primary protlem encountered was excessive rigidity of the 5-1/2 inch diameter well screen and external casing packer. Though the 5-1/2 inch diameter screen was capable of negotiating the radius of the curve, it tended to be extremely stiff. Once passing through the curve it retained some of the deformed shape and thus dug into the top of the borehole lateral past the curve. Even using extreme down-pressure, rotation, and back-and-forth movement, the screen could not be installed more than 15 to 20 feet past the curve.

Also, the external casing packer and rotary port collar were extremely rigid; their clearances through the curves were extremely small. Clearances between borehole walls and well materials should be maintained to at least one inch on all sides to facilitate installation. Ideally, nothing of greater rigidity than that of the screen should be installed through the curve. The separation of the 2-3/8 inch screen from the rigid external casing packer assembly during an attempt to install AMH-2 illustrates the potential problems encountered when using excessively long, rigid well materials.

Standard 4-1/2 inc i diameter stainless steel, wire-wrapped 0.010-inch screen, with a combination of greater flexibility and adequate strength, was selected for well completion. The 4-1/2 inch screen also permitted slightly larger clearances with the borehole walls through the curve. To ensure adequate flexibility of materials through the curve the screen was installed up to the vertical porion of the borehole. The rigid external casing packer designed to be placed in the lateral was replaced with two, short, flexible cement baskets placed in the vertical portion of the borehole. A flexible 5-foot guide of similar diameter was attached to the front of the screen to help guide the well screen through uneven or washed out portions of the boring. 


\subsection{CONCLUSIONS}

1. The study showed that horizontal wells can be successfully drilled and completed in unconsolidated sediments for the purpose of testing new methods of in-situ remediation of soils and ground water. The holes were drilled using a mud-rotary system with a short-radius tool developed by Eastman Christensen.

2. Hole stability and flexibility of well materials are the two most crucial aspects of a successful drilling program.

3. Hole stability must be optimized by (1) minimizing the number of trips in and out of the hole, (2) maintaining drilling fluid circulation at all times, and (3) not enlarging the hole after drilling is completed.

4. Well materials must exhibit (1) adequate flexibility to negotiate the curve and to resist excessive deformation, and (2) adequate strength to permit considerable downward and upward forces. Light flexible seals for the boring should be placed in the vertical section, unless an alternative method of sealing in the lateral can be developed. A flexible guide should be attached on the front end of the screen to aid in installation of the screen through the curve and the lateral.

5. Overall drilling performance was controlled by: (1) specific geologic conditions (percentage of fines), (2) rigid drill mandrel configuration, (3) drill-bit speed and weight, and (4) drilling fluid pumping rates. The preferred target zones for optimization of drilling performance contain minor amounts of clay, which improves the competency of the geologic unit.

6. The optimum drilling fluid has the following characteristics: (1) low weight, (2) high lubricity, (3) moderate to high viscosity, and (4) moderate yield point. An experienced mud engineer is required in the planning stages and on site to maintain an optimum drilling fluid.

7. One-step grouting of the whipstock is recommended. A Portland cement with $2 \%$ calciumchloride accelerator is recommended.

8. Horizontal well costs can be significantly reduced using the experience gained during this project. 


\subsection{RECOMMENDATIONS AND PLANS}

\subsection{Recommendations}

During the course of this project several procedures and design specifications were altered as new information about drilling performance in unconsolidated sediments and requirements of well installation materials was obtained. The following are the major recommendations for consideration if future projects of this nature are planned.

1. Flexibility should be maintained in as many aspects of the program as possible. The ability to adapt to changing or unforeseen site conditions and project requirements with minimum disruption and delay to the project greatly facilitates efficient and successful completion of project objectives.

2. Trips in and out of the borehole should be minimized to reduce wear on the curve and to maintain hole stability in the lateral.

3. Interruption of drilling-fluid circulation should be minimized. Whenever circulation is stopped, (1) chances of drilling fluid loss, (2) decrease in hole stability, and (3) blockage of th hole by unremoved drill cuttings are greatly increased. All downhole survey shots, changing of drilling equipment, and installation of well materials should be performed as quickly as possible.

4. The hole should not be enlarged with a hole-opener. Drilling should be designed to achieve the desired borehole diameter with the first drill bit. Reaming of the initial borehole with a hole-opener bit destroys the filtercake on the borehole walls, decreases borehole stability, and significantly contributes to the degradation of the curve through increased wear.

5. Well materials should possess adequate strength and flexibility to negotiate the curve. A strong but flexible guide attached to the front of the well screen aided in guiding the well materials through the curve and the lateral portion of the borehole. The ability to circulate drilling fluid out the front of the well screens is crucial to clear the borehole path of slough material or unremoved cuttings.

6. Detailed geologic information along the length of the proposed laterals should be obtained prior to initiating well design or design of the drilling program. Geotechnical borings should be drilled prior to selection of target zones and ordering of well materials. Split-spoon samples should be taken in accordance with ASTM standards. Blow-count information could then be used to estimate density, soil strength, and permeability. Sieve analyses, with porosity and permeability calculations, should be performed ahead of finalizing the well design.

7. The accuracy of whipstock alignment should be improved. Alignment should take into account the fect that the bit tends to drive and roll to the right in soft clays.

8. An experienced mud engineer should be retained for all drilling activities and should be consulted during the planning of the drilling program. Familiarity with specific site conditions and associated drilling fluid requirements greatly increases the quality of drilling performance and installation. 


\subsection{Plans}

1. The in-situ remediation tests should be conducted. Tests in horizontal wells should be compared to comparable tests in vertical wells. The possibility of using a horizontal injector well and vertical extraction wells should be examined.

2. Other technologies for drilling horizontal wells should be tested for environmental applications. The water-jet drilling technology, where the casing is advanced as the hole is drilled, appears to be very promising.

3. Attempts should be made to reduce costs for this type of drilling, so that this method of remediation could be cost-effective. 


\subsection{SELECTED REFERENCES}

Beard, D. C. and D. K. Weyl, 1973. Influence of texture on porosity and permeability of unconsolidated sand. Am. Assoc. Petrol Geol. Bull., V. 57, p. 349-369. 
APPENDIX A

GEOLOGICLOG

AMH-1 
FIELD GEOLOGIC LOG

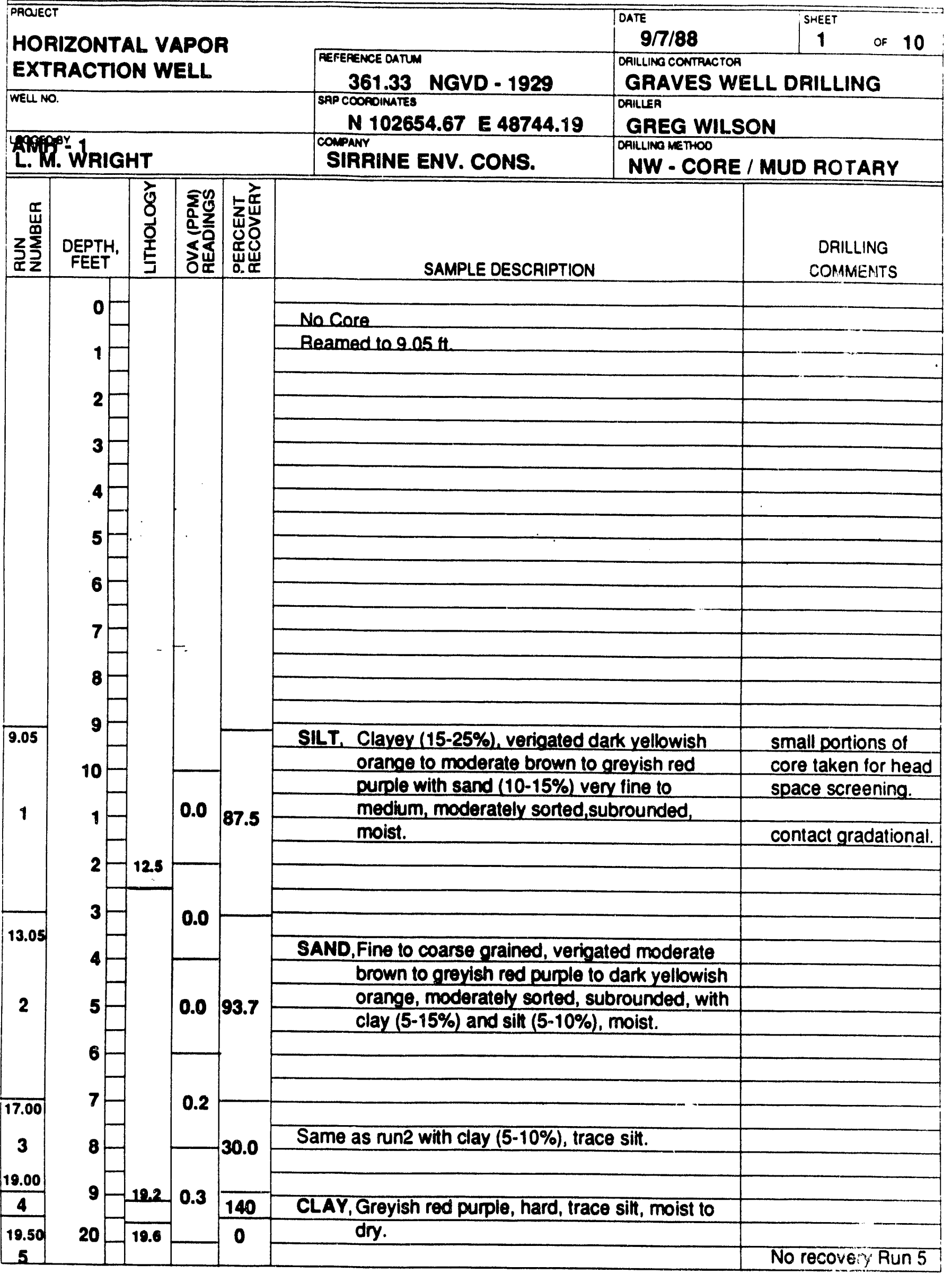


FIELD GEOLOGIC LOG

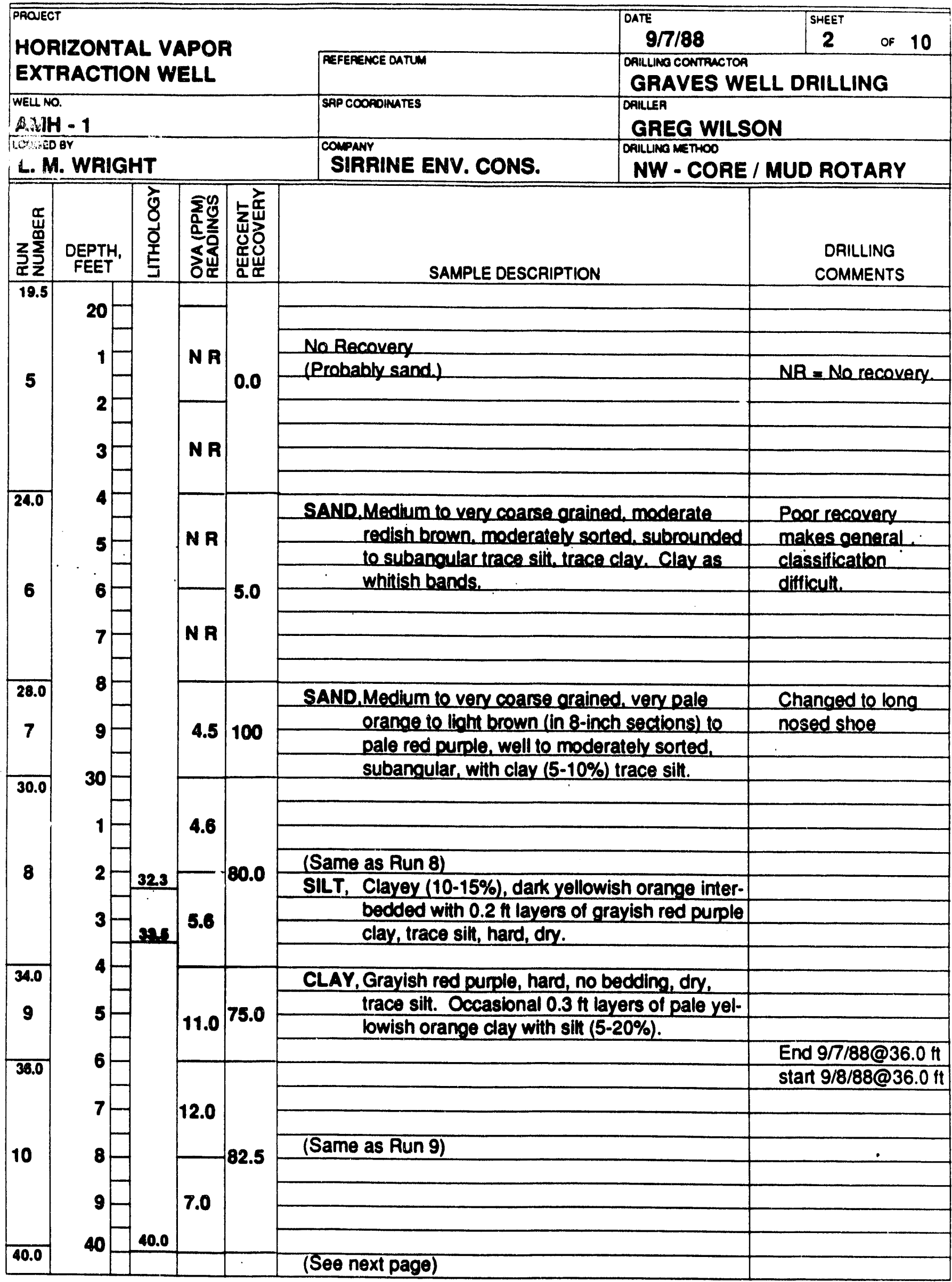


FIELD GEOLOGIC LOG

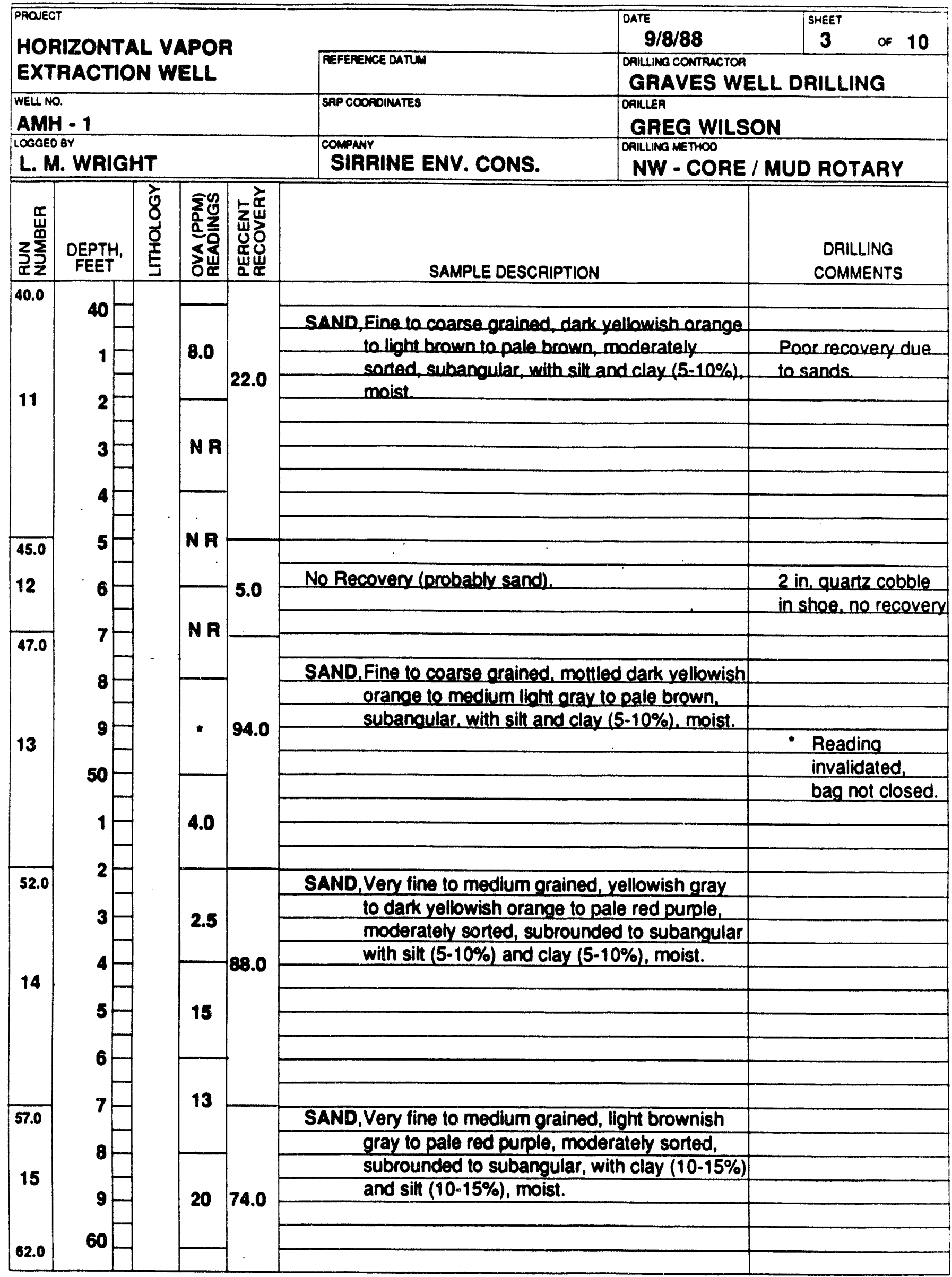


FIELD GEOLOGIC LOG

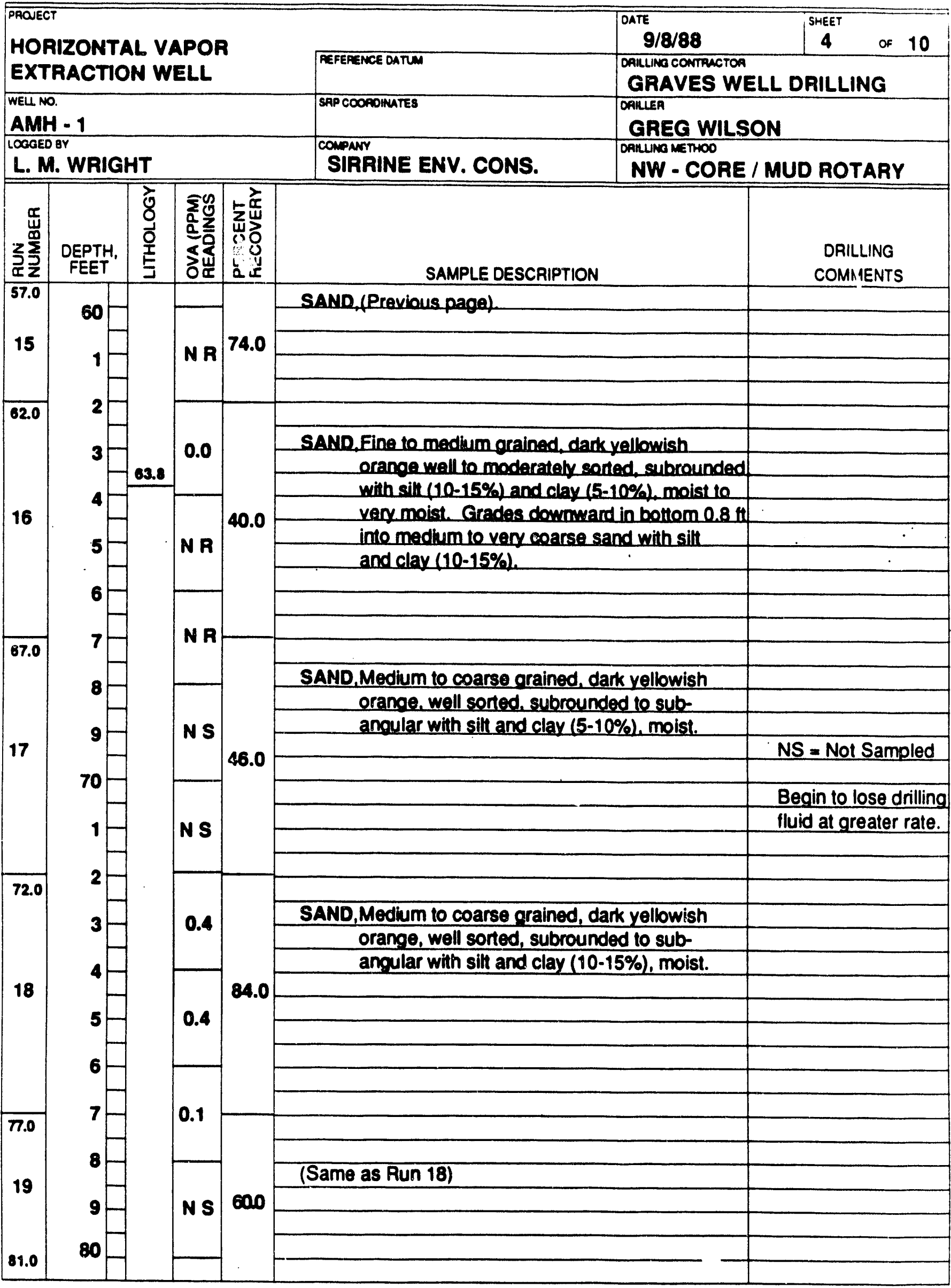


FIELD GEOLOGIC LOG

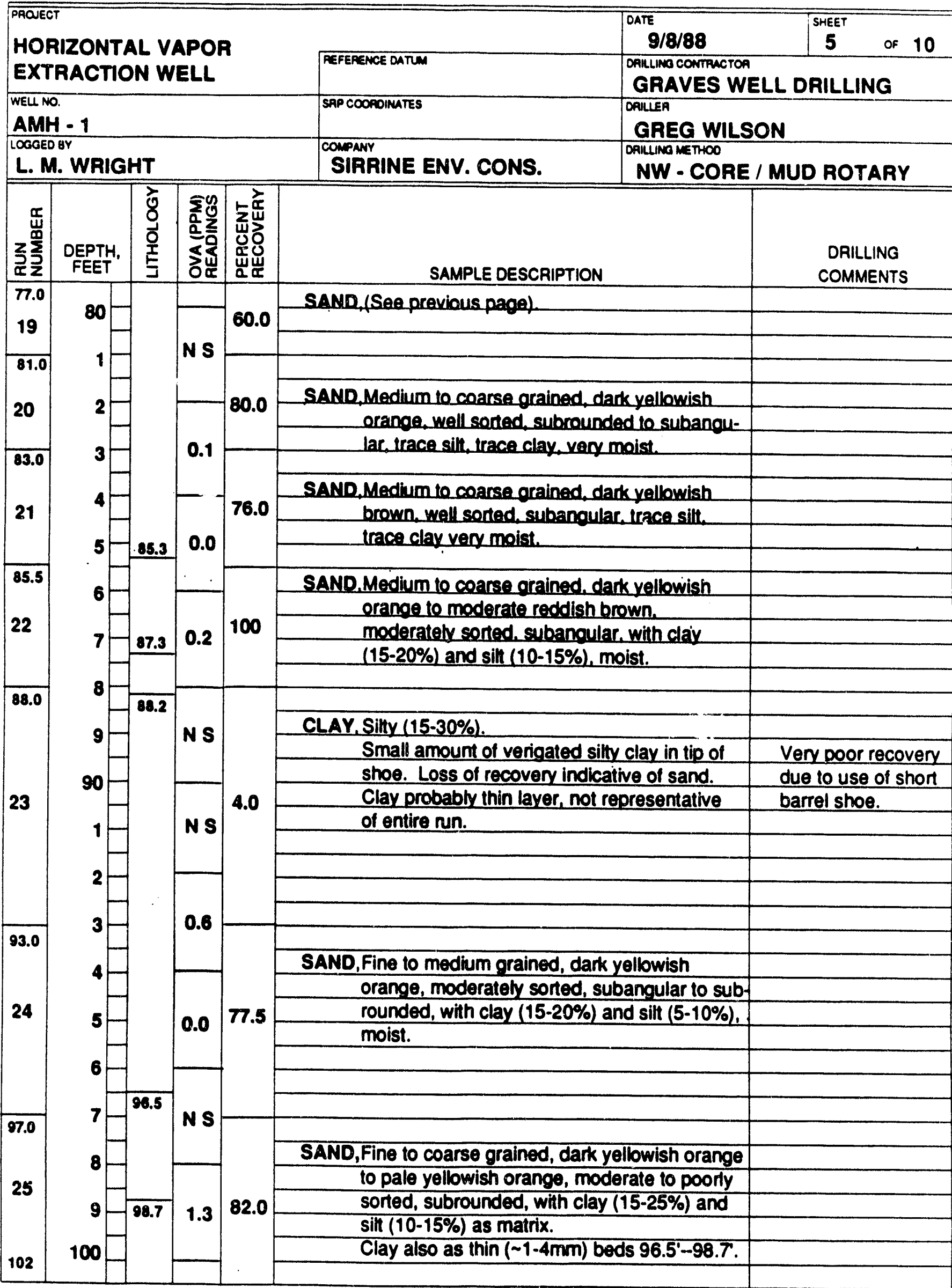


FIELD GEOLOGIC LOG

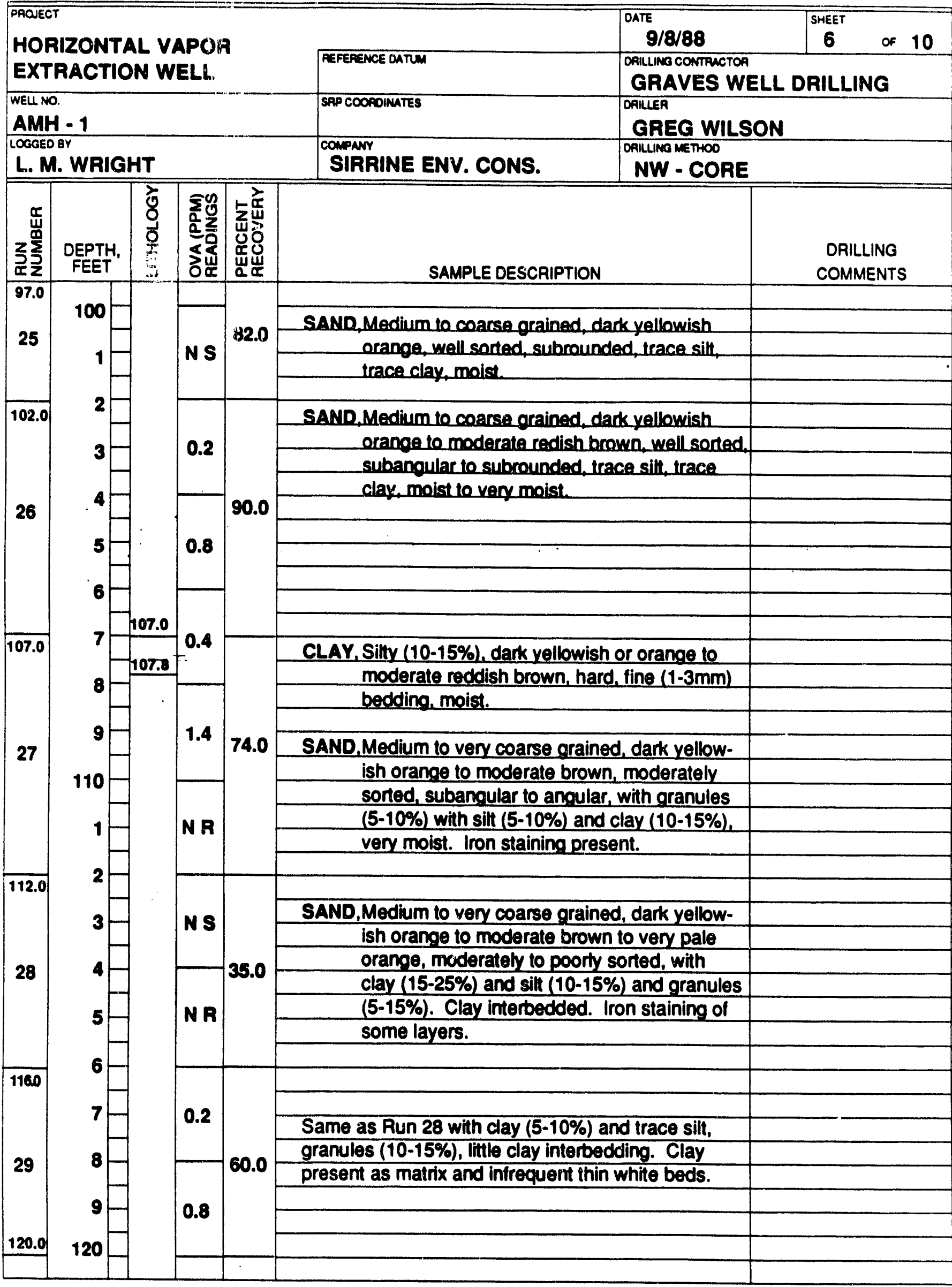


FIELD GEOLOGIC LOG

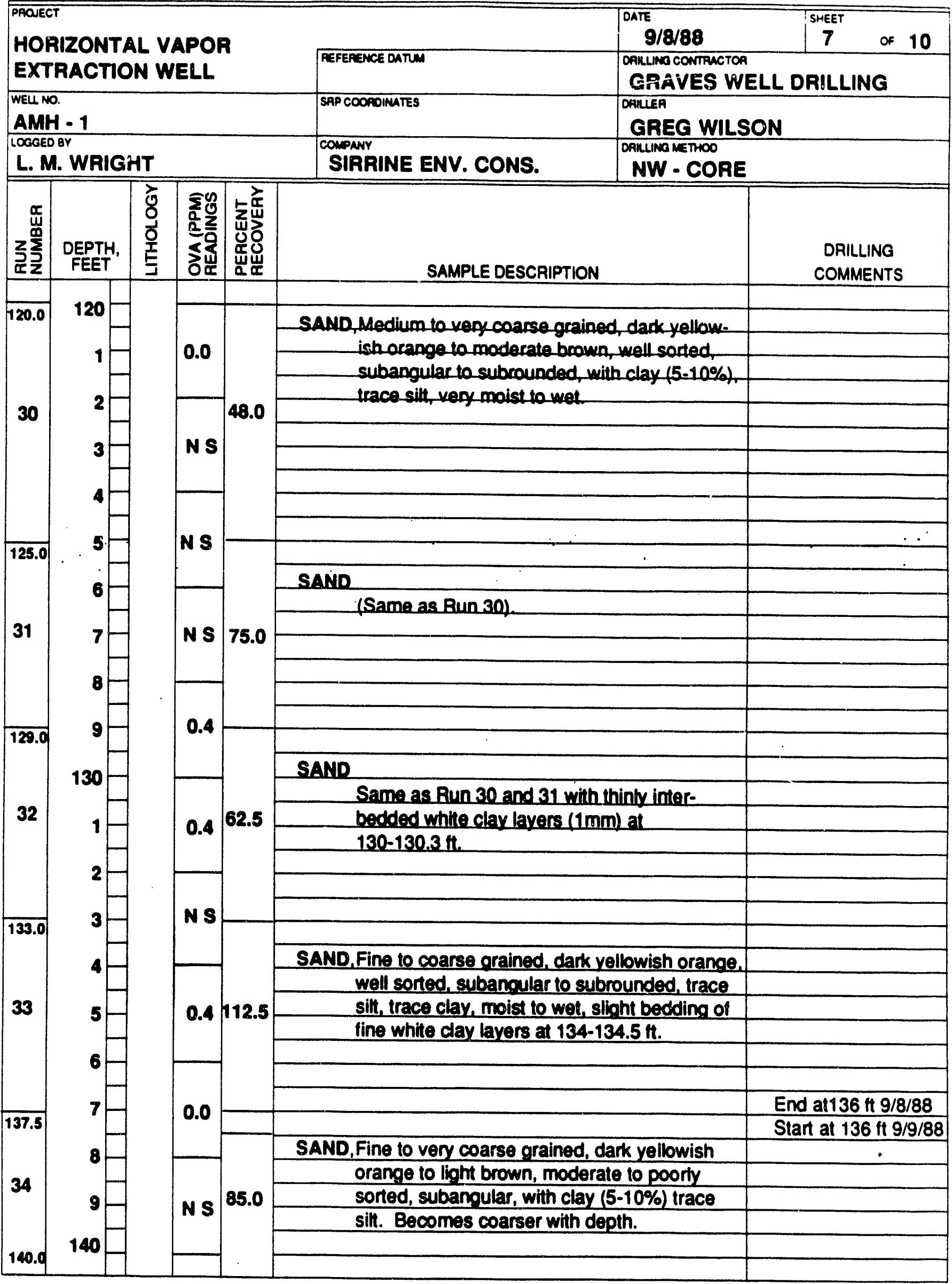


FIELD GEOLOGIC LOG

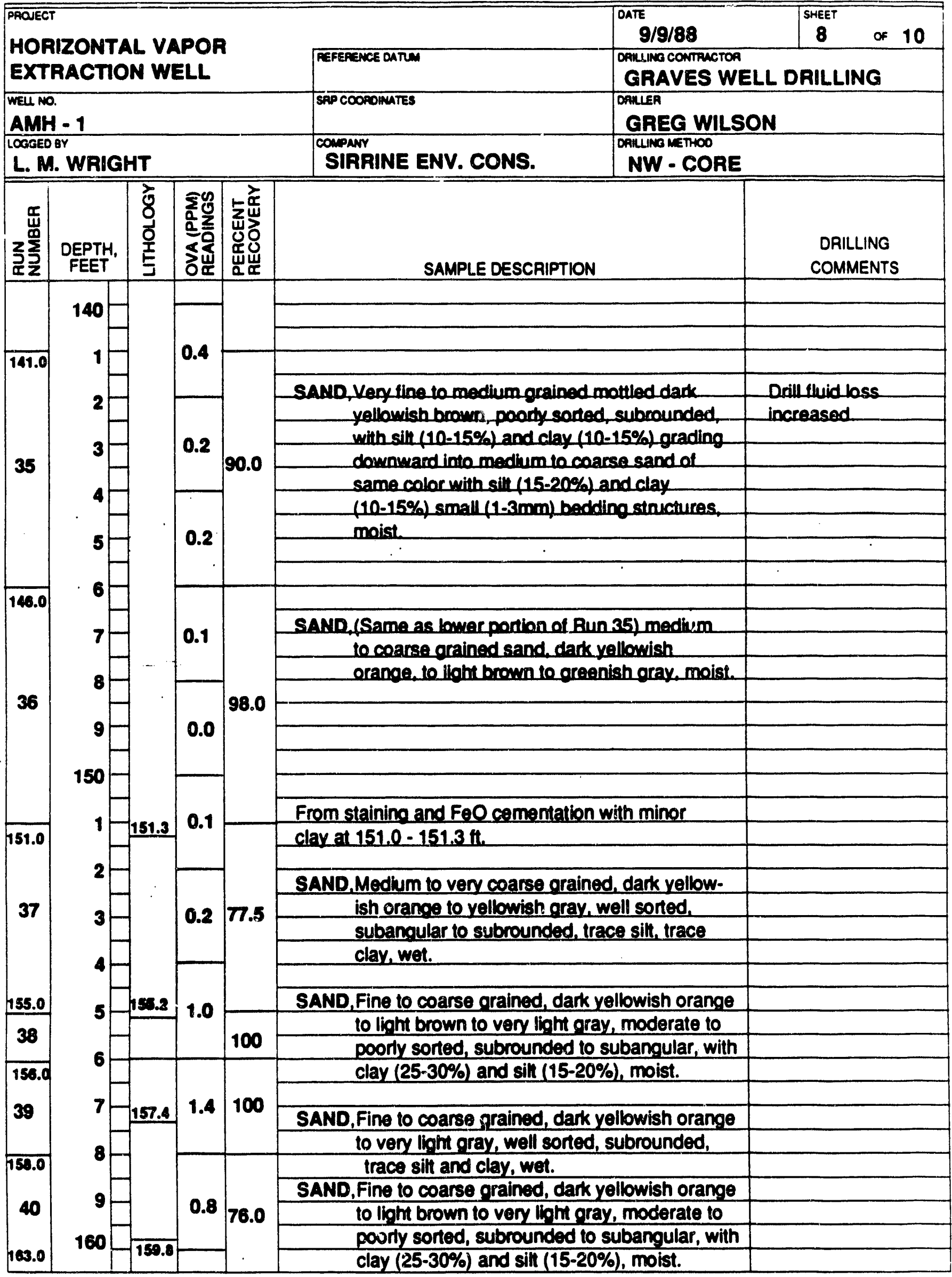


FIELD GEOLOGIC LOG

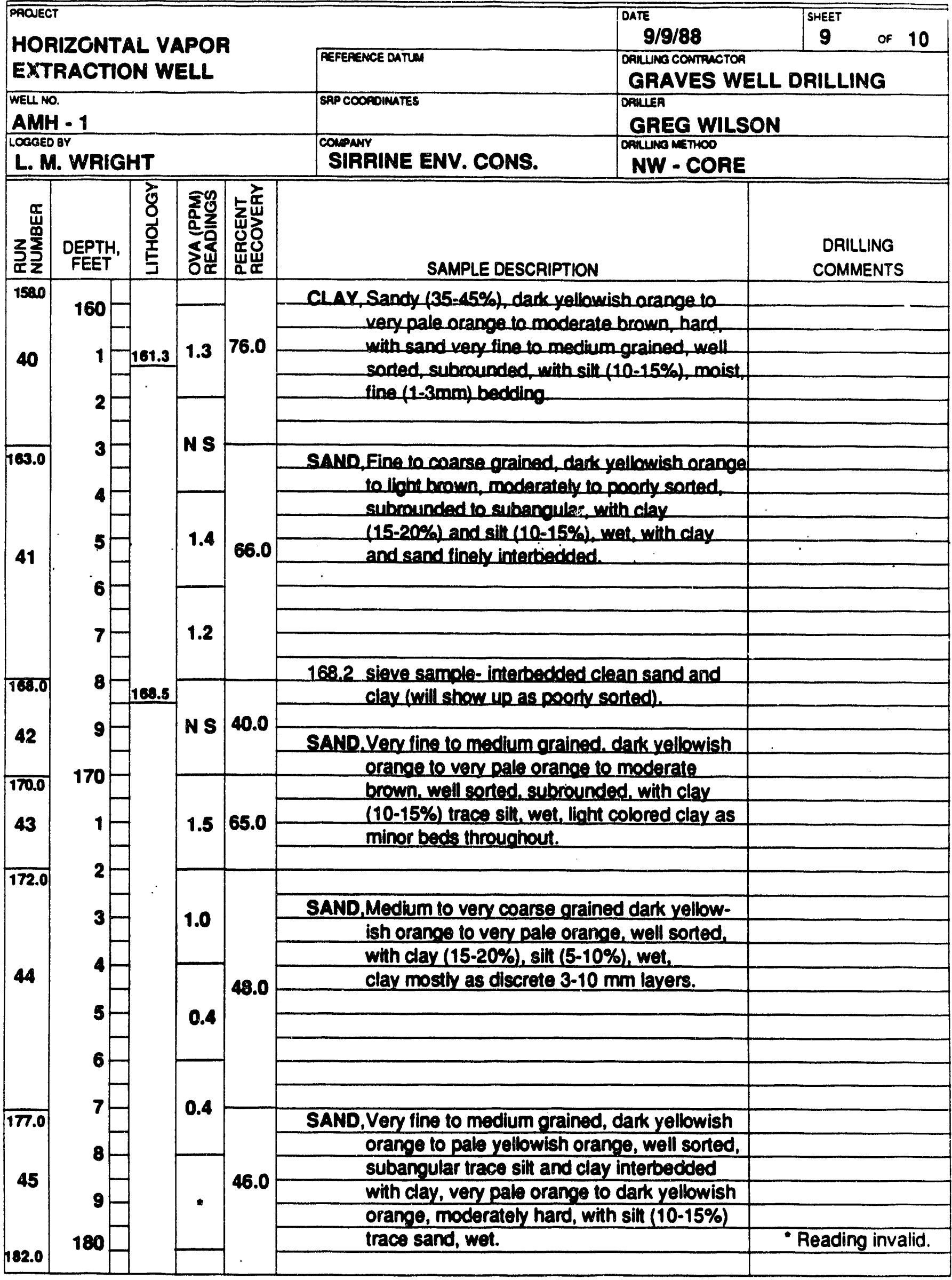




\section{APPENDIX B}

\section{GEOPHYSICAL LOGS}




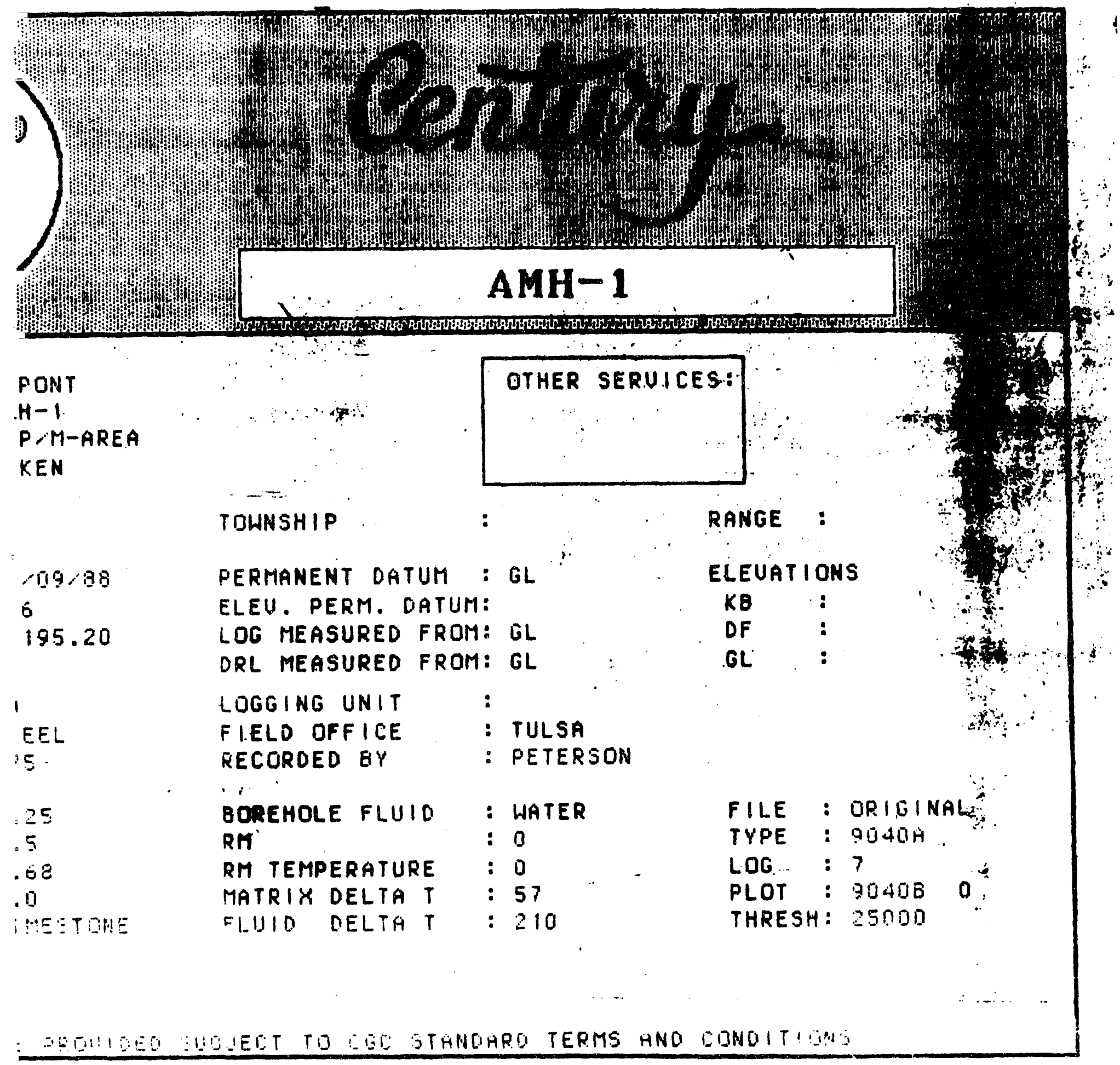



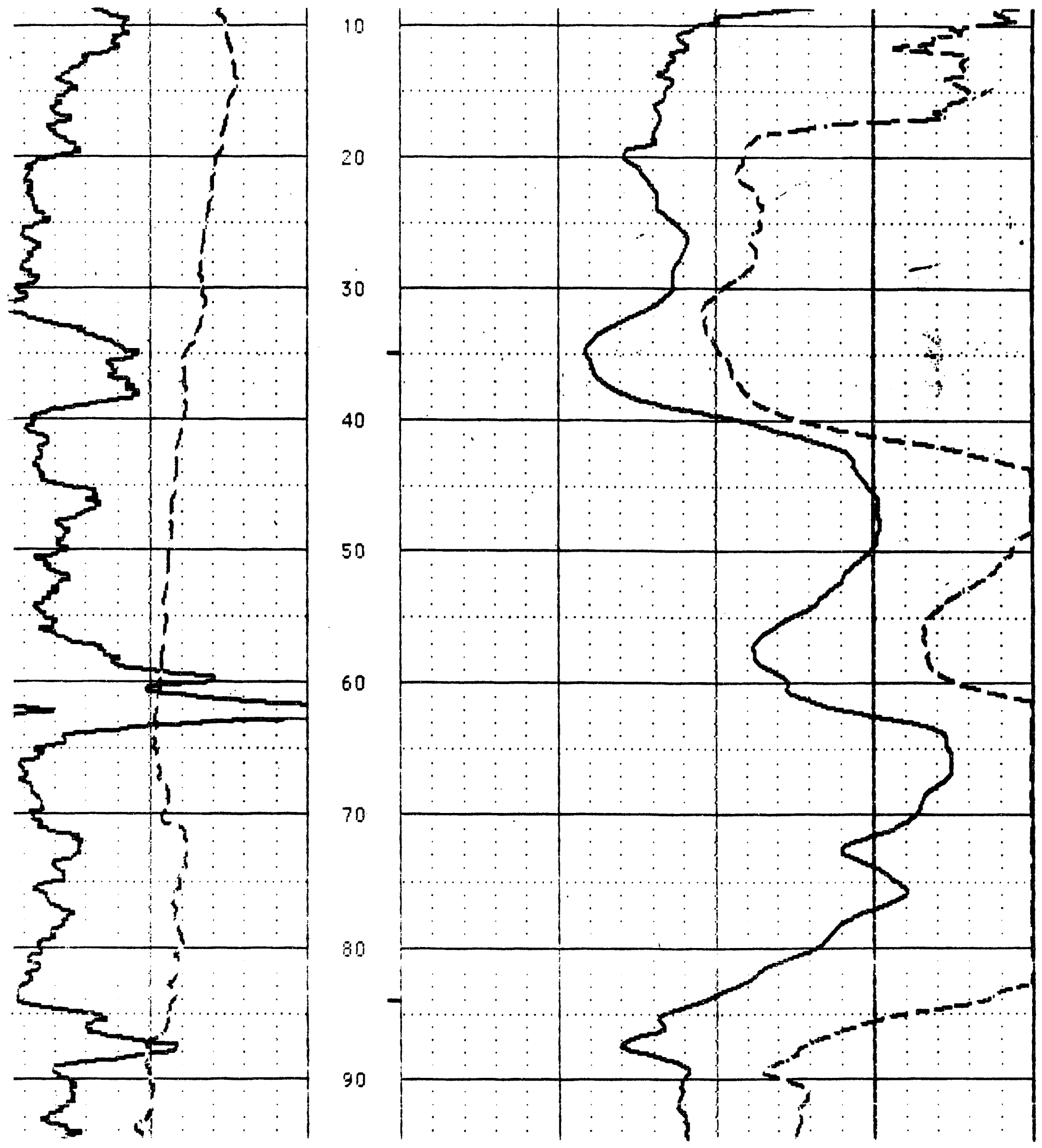

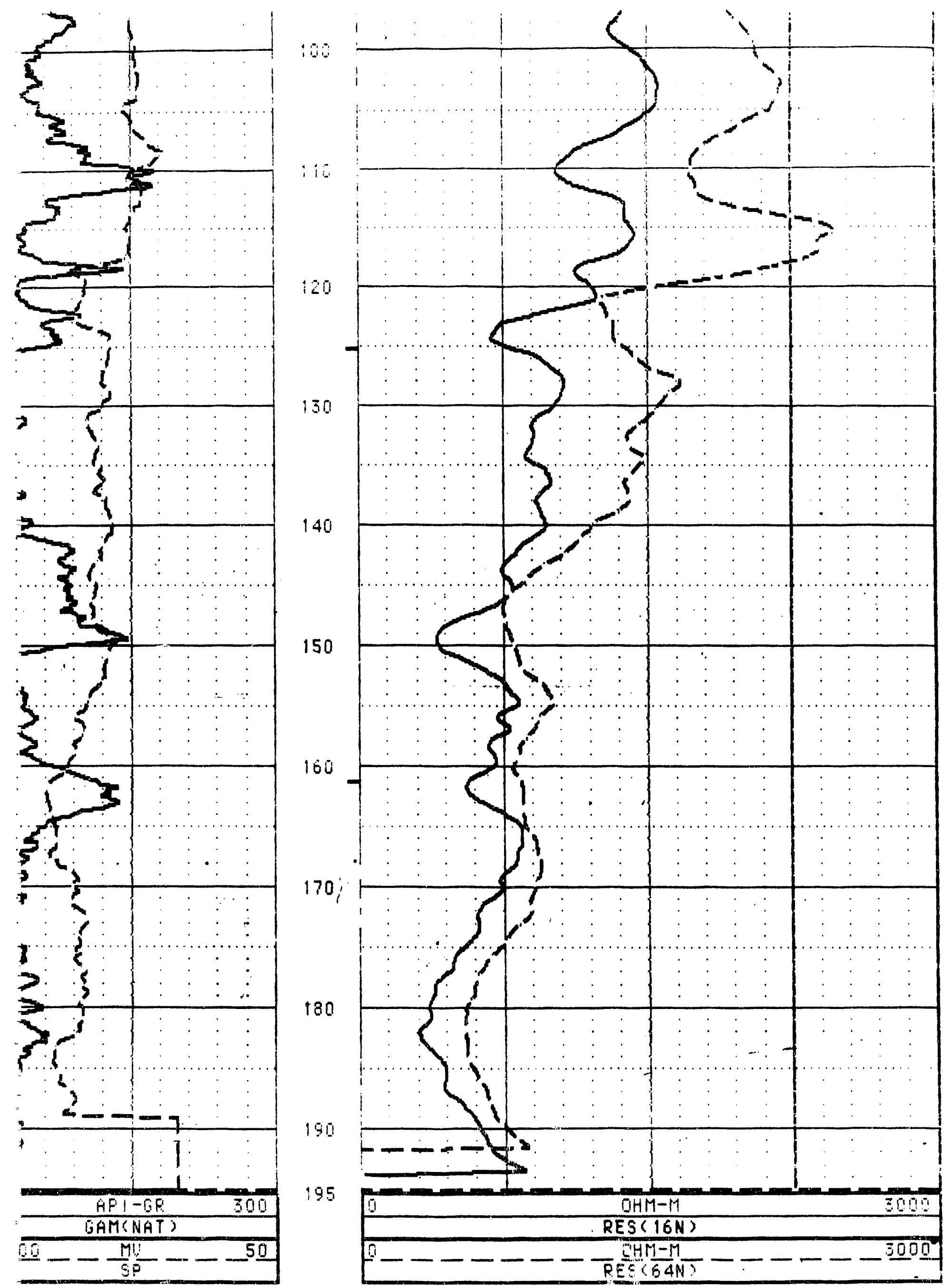


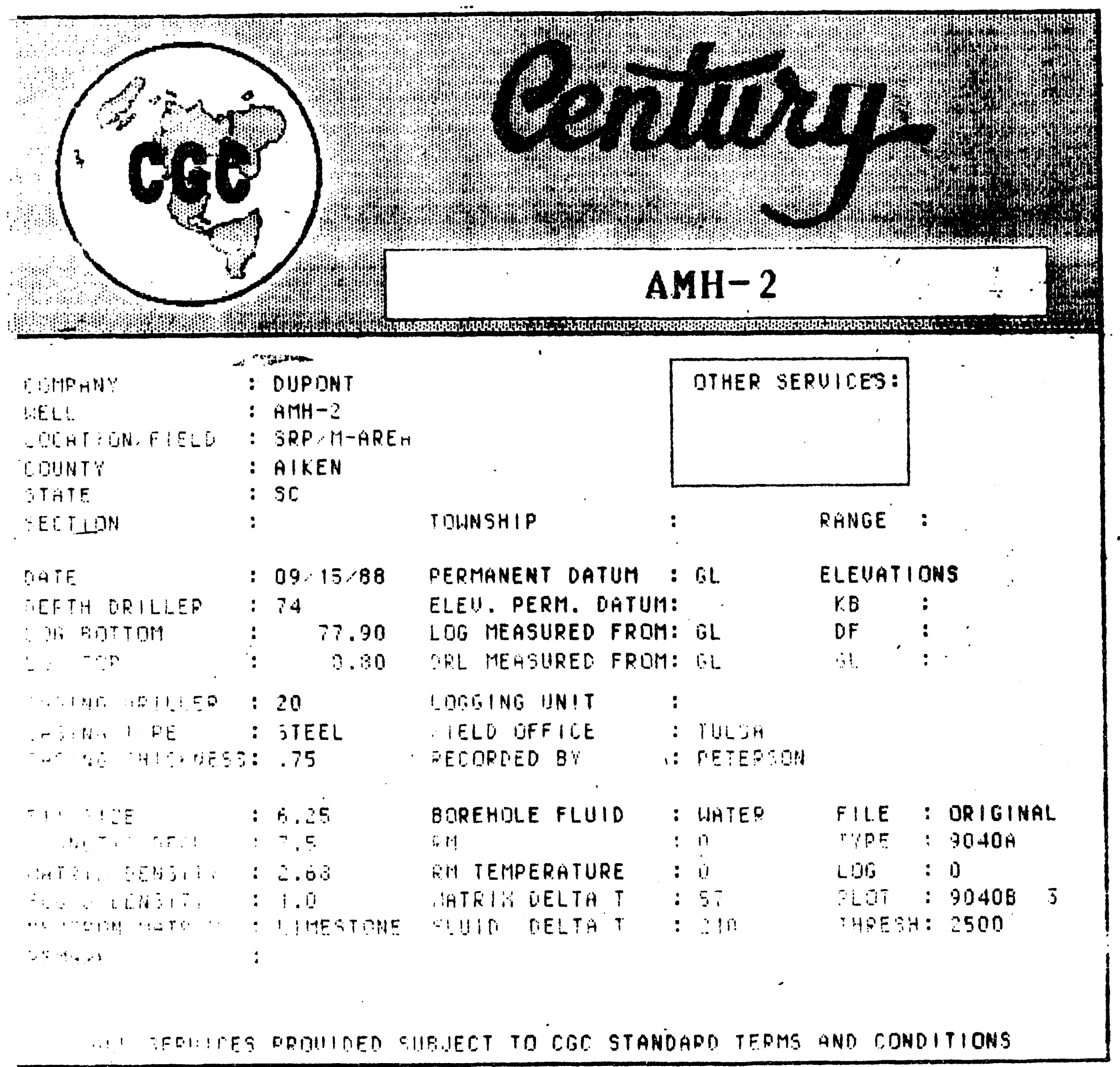




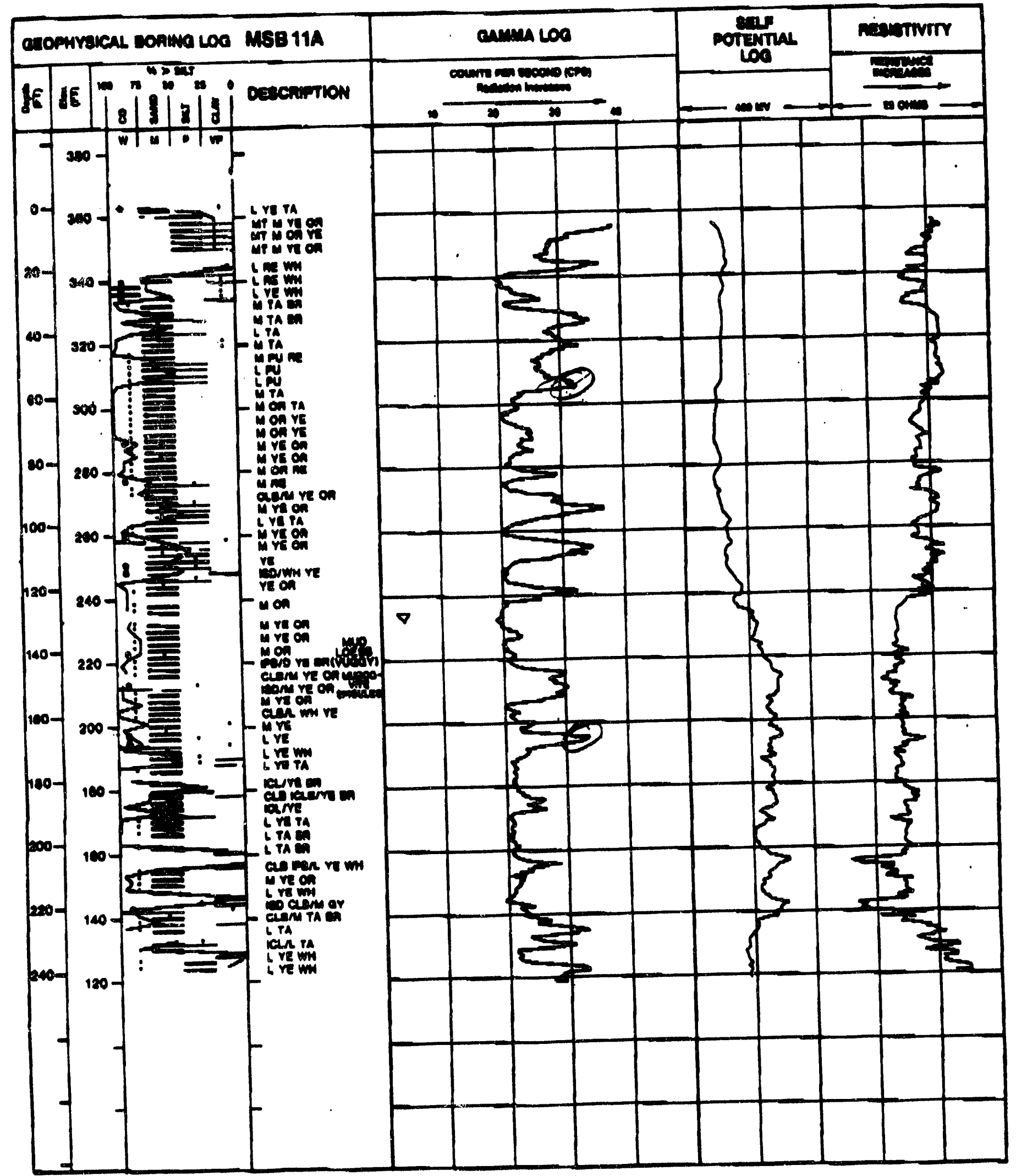




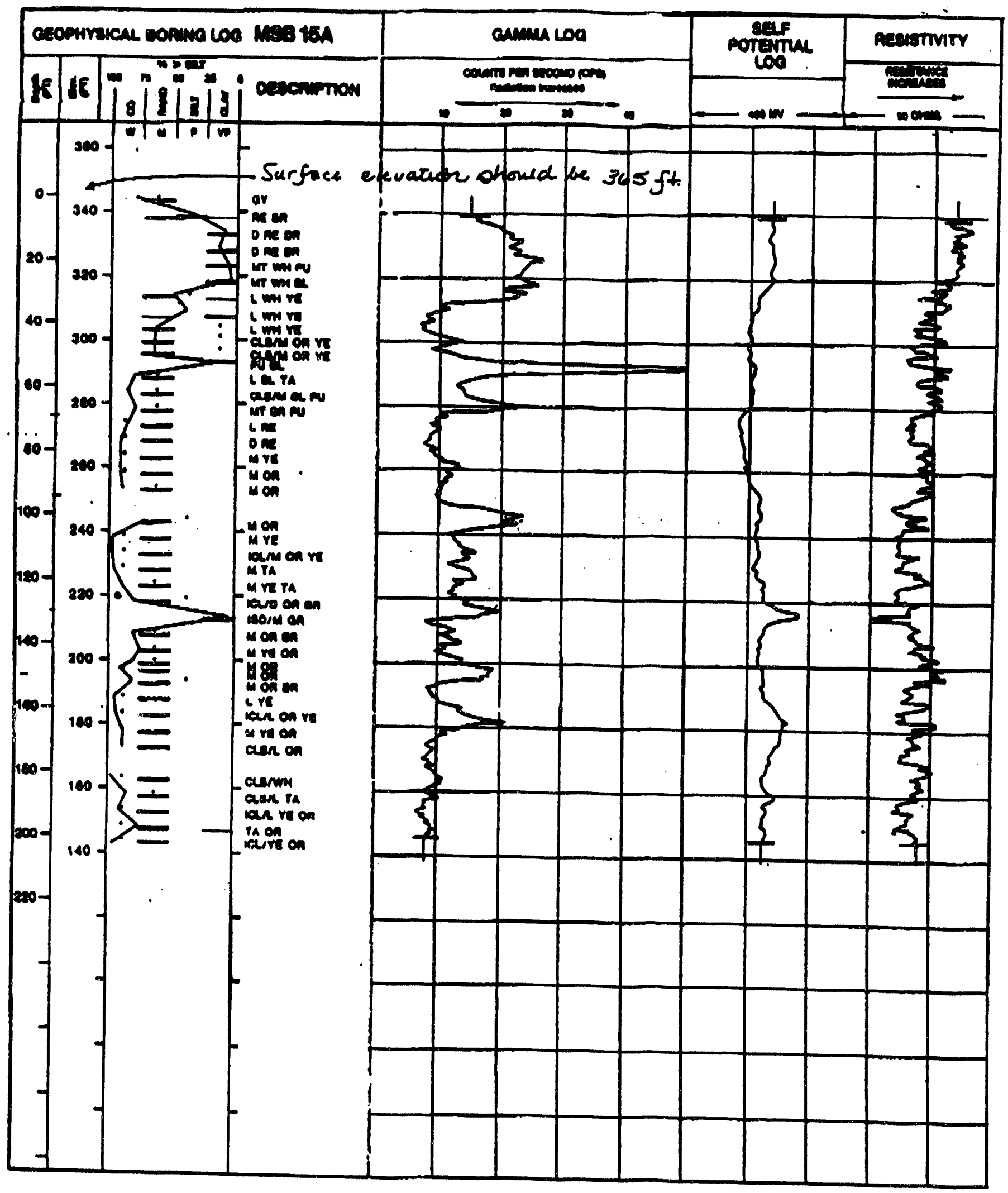


APPENDIX C

DRILLING PROGRAM PLANS

AMH-1

AMH-2 
DRILLING PROGRAM

AMH NO. 1

AREA $M$

DU PONT SAVANMAH RIVER PLANT

AIKEN, SC

Prepared by:

Edward G. Dow

Conoco PER

Approved by:

David H. Schwartz

Conoco PER

Approved by:

E.I. Du Pont de Nemours and Company 


\section{SAFETY}

E. I. Du Pont de Nemours \& Company, Inc. is committed to safety. The plant safety book will be followed. Section seven of the Conoco NAP Safety Manual, which pertains to drilling, will also be used as a guide. The Du Pont representative (Conoco supervisor) on location and plant safety personnel will monitor safety and provide input on those occasions where specific safety questions arise.

The drilling contractor will be required to meet all applicable OSHA requirements for equipment and personnel. The drilling contractor wust provide only drill rig operators who have been certified by the State of South Carolina. The contractor must ensure that appropriate safety precautions are taken at all times. Prior to initiation of work, a safety brlefing shall be given by plant safety personnel. The contractor must then demonstrate familiarity with applicable safety precautions. 


\section{REPORTS}

The experimental nature of this well requires that excellent records be maintained to document the drilling and completion of this well. All drilling logs, completion logs, and pressure charts shall be labelled with details explaining the particular operations performed. Details shall include the reason for the operation, scales, notations of procedural steps, and alterations from the approved procedure. All original recordings (including tally books and daily reports)will be saved and filed for future reference. Detailed End of Well reports will be required of all service companies.

This well will be a team effort by all personnel on the rig site. The following division of reporting responsibilities is made to clarify the requirements of each individual and to decrease the opportunities for conflict.

IADC Tour Reports (which will be supplied by Conoco) are to be completed at the end of each tour and signed by the drilling contractor. The drilling contractor will be required to keep an accurate record of all equipment dimensions during vertical drilling operations and during completion and development operations.

The directional services company will provide at well site, a $30^{\prime \prime} \mathrm{x}$ $40 "$ plot of the proposed directional plan. This plot will include both a plan viow and a section view. The plot will be posted in the DuPont representative's trailer. The directional company will post all surveys on the plot to ensure that a detailed, current comparison between the well plan and actual performance is maintained. The directional company will keep a detailed record of all equipment dimensions in the hole during their active operations.

The solids equipment/mud hand will run mud checks and fill out mud check sheets. He will also be responsible for ensuring proper mud additions are made (with the DuPont representative's approval) and the solids control equipment is in proper operating condition. The DuPont 
representative will post morning reports for DuPont and Conoco. He will also keep duplicate records of all equipment in the hole and make the necessary calculations for on site modifications to the proposed well plan. It will also be his responsibility to compile the end of well report which will incorporate and summerize those supplied by the contractors and service companies. 


\section{PURPOSE}

The drilling and completion of the AMH No.1 and AMH No.2 are part of continued experiments to test the feasibility of vacuum extraction methods to recover volatile hydrocarbons from an aquifer. In this phase of the project, two horizontal wells will be drilled in the same vertical plane. It is the intent that the deeper well (AMH No. 1) will be located below the contaminated portion of the aquifer which is approximately the top 55 feet below the water table. The second well (AMH No. 2) will be located approximately 50 feet above the water table in the Vadose zone. Upon completion, air will be injected into the AMH No.1 at a rate up to 500 to 1000 cubic feet per minute. AMH No. 2 will be subject to a vacuum which will attempt to produce air at approximately the same rate as the injection rate in the AMH No. 1. The agitation and additional surface area created by blowing the air through the water will release additional volatile hydrocarbons.

Further testing may be performed in a second phase using the horizontal injector (AMH No. 1) and the three existing vertical Vadose zone wells (VB Nos. 1,2, and 3). Air injection will continue from AMF No. 1 and the vertical wells will attempt to produce air at a rate similar to the injection rate. Various configurations may be used to provide a comparison between the efficiency of the horizontal vacuum extraction well and the vertical vacuum extraction wells. 
Objective: Drill and complete a horizontal test well below the water table. The subject well will be completed with a wire wrapped, rod based screen in the 300 foot long horizontal section. Total measured depth is anticipated to be 553 feet with a total vertical depth of 180 feet. Total horizontal displacement is expected to be 350 feet. The subject well will be used as an air injection well in the experimental vacuum evacuation tests. A horizontal vacuum extraction well is also part of this project and is covered by the AMH No. 2 wellplan.

Location: . Aiken County, South Carolina.

*Latitude - 33.335031

*Longitude - 81.735643

*SRP Coordinates:

* N 103038

* E 49882

Directional: Magnetic Declination - $4^{\circ} 5^{\prime} \mathrm{W}$ of true $N$ (as of Jan 29, 1988); Rate of change $=8.1^{\prime} \mathrm{W} / \mathrm{yr}$

Local Grid (SRP Grid) North $-36^{\circ} 22^{\prime} W$ of true $N$

Elevation: ${ }^{\star G r o u n d}$ Level about $365^{\prime}$ above Mean Sea Level (MSL)

Water Table: $235^{\prime}$ above Sea Level

*NOTE: The proposed wellsite will be surveyed. These values may change based upon the exact well position. 


\section{DRILLING PROCEDURES}

1. Location Preparation - The location shall be built according to specifications in DPSOP 254, Revision 0, Chapter 5, Sections B.4 and B.5. The areal extent of the location shall be sufficient to provide space for the following equipment: rig, two flatbed trailers (pipe and EC equipment), water storage tanks (or access to pit for water haulers), mud pumps, four section steel mud tank, organized storage of miscellaneous subs and wellhead equipment, as well as space for mud product storage (palleted bentonite, palleted calcium carbonate, and covered storage for polymers).

- Additional location space shall be provided beside the roadway for a DuPont representative's trailer. This trailer location should be about halfway between the AMH No.1 and AMH No. 2 locations. Adequate off roadway parking should be provided at the trailer to prevent parking at the wellsite. Parking surface should be roadway material.

2. Move in and rig up wireline coring rig. Core from surface to 190 feet (final depth to be determined by DuPont representative) as specified in DPSOP 254, Revison 0, Chapter 3, Section B.2.4.

3. Submit cores to the Environmental Services Division (Dawn Kabach) for analyses. Sieve analysis will be performed every $10 \mathrm{ft}$ over the interval from $50 \mathrm{ft}$ to $190 \mathrm{ft}$. These analyses will be used to size the screen.

4. Rig down and move off wireline coring unit.

5. Move in and $\mathrm{rig}$ up rotary $\mathrm{rig}$ as specified in the Rig Specifications (pg. 24).

6. Drill 16 inch hole to \pm 190 feet using the drilling mud specified in the Mud Program (pg. 14). 
7. Circulate and condition hole with 25 bbls. of viscous pill specified in Mud Program followed by 80 bbls ( 2 hole volumes) of mud used for drilling.

8. Run Compulog I (GR-SPRES-16"SN-64"LN-CAL) logs.

9. Plug back with a fine sand (such as $40 / 60$ or blast sand) to 39 feet above depth of desired lateral specified by geologist. (Probable lateral depth is $180 \mathrm{ft}$. Probable plug back point is $141 \mathrm{ft}$. Hole volume is $1.397 \mathrm{cu} \mathrm{ft} / \mathrm{ft}$ )

10. Run whipstock joint and 111 feet of 8-5/8" (8" nominal) Sch. 40 line pipe for casing to a TVD of 141 feet as specified in Casing Running And Cementing Procedure (pg. 17). Dimensions for the whipstock joint are given in Figure No. 7. Orient whipstock and casing to $237.87^{\circ}$ (ref TN) whille running pipe. NOTE: whipstock orientation will vary depending on final surface locations. Set casing on bottom and hang off on rig floor.

11. Run in hole with drill pipe. Rig up casing packoff on last joint of drill pipe. Batch mix 16 sacks Cal-Seal using 4.8 gallons of freshwater per sack. Ensure that wix water temperatures are below $80^{\circ} \mathrm{F}$ to prevent flash setting. (Note: Sample testing for pumpability will be performed on site.) Using balanced plug method, spot Cal-Seal on bottom. (Casing-Hole Annulus 0.1772 bbls/ft or $0.9947 \mathrm{cu} \mathrm{ft/ft;} \mathrm{Casing} \mathrm{Capacity} .0621 \mathrm{bbls} / \mathrm{cu} \mathrm{ft}$ or $0.3489 \mathrm{cu} f t / f t ; C a l-S e a 1$ Yield $1.24 \mathrm{cu} \mathrm{ft} / \mathrm{sx}$; Cal-Seal Density 15.1 Pps)

12. Allow Cal-Seal to set 1 hour.

13. Grout casing in place as specified in Casing Running And Cementing Procedure (pg. 17) Top of Cal-Seal is expected at 126 feet (15 feet off bottom). 
14. Allow grout to set 8 hours (minimum allowable compressive strength 500 psi) before drillout.

15. Rig up centrifugal pump, flowline cleaner with $120^{\prime} \mathrm{s}$ or 8 cone mud cleaner with $120^{\prime}$ s over $175^{\prime}$ s, and 4 section metal mud pit as shown on Figure No. 8. Have a selection of screens from 120 to 220 mesh available on location with replacements.

16. Install $8-5 / 8^{\prime \prime}$ tee head and mud return line to dirt pit.

17. Lay down dril1 rods and tubing. Pick up 3-1/2" EUE drill pipe with API 3-1/2" IF joints modified for drill rod tongs and carousel. Rig up tongs and slips for Eastman Christensen equipment. For convenience, the modified $3-1 / 2$ " may be run pin up but EC equipment must be run pin down. (3-1/2 IF pin $\times 3-1 / 2^{\text {" }}$ IF pin sub required at top of EC equipment.)

18. Rig up Eastman Christensen.

19. Drill out whipstock and pilot hole using 6-1/2" short shank tricone bit (API 111) with an open throat, 1 joint wiggly drill collar, and modified $3-1 / 2 "$ drill pipe. Clean off whipstock and drill 2 to 3 feet of open hole. Wipe out window if necessary.

20. Drill angle bulld section using $6-1 / 2^{\prime \prime}$ short shank tricone bit (API 111) with an open throat, curved drill guide, and modified 3-1/2" drill pipe.

21. Surveys in the angle building section of the hole will be performed after drilling 15 feet, 30 feet, 45 feet, and 60 feet. Rig up slick line unit and pump down single point surveys at the specified depths. Use a 15 foot pup joint to keep the pumping head at the drill floor. Since high ROP's are expected, double chain slick line sheave to derrick and leave sheave, slickline, pump down head and packoff, and upper portion of survey tool in derrick at all times. 
22. If difficulty in obtaining adequate angle is experienced, perform the following.
a. Run in hole with open ended drill pipe.
b. Plug back hole 11 feet with 2 sacks Cal-seal.
c. Allow Cal-seal to set 1 hour.
d. Re-drill hole.
e. Survey new hole position.
Immediately upon completion of the survey, plan and section views and tabular format will be posted by Eastman Christensen in the Du Pont representative's trailer.

NOTE: All directional surveys will be reported in degrees and decimals. All azimuth readings will be recorded in degrees clockwise from True North. (Quadrant reference is not acceptable.) Well position coordinates will be recorded in the local SRP Grid Coordinate System and noted as such.

23. Dri11 350 foot lateral using 6-1/4" tricone bit (API 111) with an open throat, 6" diameter nearbit stabilizer, 5.72" diameter steering stabilizer, 420 feet of wiggly drill collars, and 140 feet modified 3-1/2" drillpipe. This assembly has an aggresive build rate $\left(40^{\circ} / 100 \mathrm{ft}\right)$ to compensate for anticipated washout. Take directional surveys using the pump down single shot on slickline every 60 feet of drilled lateral.

24. After drilling to TD, circulate and condition hole using the following procedure:

a. Pump drilling mud at 140 to 230 GPM for 2 to 3 hole volumes.

b. Puip 10 bb1 viscous sweep (add suction line volumes) as specified in the Mud Program. Attempt to maintain a circulation rate of 100 to 140 GPM.
c. Pump 2 additional hole volumes of drilling mud maintaining 140 to 230 GPM rate.

d. Spot viscous pill on buttom. 
25. POOH and 118 up for gyro survey. Run Eastman Christensen gyro survey tool on 420 feet of wiggly drill collars, and 140 feet of modified 3-1/2" drill pipe. Obtain one station every $30 \mathrm{ft}$ in the lateral and bufld sections. No stations are necessary in the vertical section. $\mathrm{POOH}$.

26. After drilling and surveying 350 feet of lateral, go in hole with 7-3/4" hole opener (Drillex 6-7/8" Simplex bit), wiggly drill collars, and drill pipe. Open hole from 6-1/4" to 7-3/4" diameter over the open hole interval (141 ft to $553 \mathrm{ft}$ ). Limit rate of penetration to $6 \mathrm{ft} / \mathrm{min}(5 \mathrm{~min} / 30 \mathrm{ft}$ joint) with a circulation rate of 225 to 250 GPM.

27. After hole opening, circulate and condition hole as in 22 above but increase the circulation rates in steps (a) and (c) to 300 GPM to prepare well for completion.

28. Rig down Eastman Christensen. Lay down modified 3-1/2" drill pipe.

29. Pull 8-5/8" tee head. Weld on threaded nipple and install casing head as per Figure No. 9.

30. Rig up casing elevators.

31. Run in hole with stab-in float shoe, 295 feet of 5-1/2" (nomina1) wire wrapped screen, $30 \mathrm{ft}$. of casing, port collar, external casing packer, and 204 feet of 5-1/2", 14 lbs./ft. plain end casing as specified in the Casing Running and Cementing Procedure (pg. 19). Strap on 2 strings of 3/4" IJ PVC tremmie pipe and 1 string of 3/8" 304SS control tubing. Attach ECP fitting and inline check to bottom of $3 / 8^{\prime \prime}$ tubing and $f 111$ tubing with water. Tie 3/8" tubing to inflation port on ECP through check valve. Hang tremie pipe $10 \mathrm{ft}$ above ECP. Band on 1 ines with 2 bands per joint orienting all strings to the top of the hole. Elevator doors must be oriented to allow feed through of external strings. 
DO NOT set casing on bottom. Cut and hang off casing in casing head. If pipe becomes stuck, use the following procedure.

a. Hang off casing on rig floor. Rig up 2-3/8" tubing tongs, elevators, and concentric slips.

b. RIH with stab-in joint and $2-3 / 8^{\prime \prime} 4.7 \mathrm{lbs} / \mathrm{ft}, 8 \mathrm{rd}$, EUE tubing to surface. Space out on last joint to put tubing joint about 1 foot above casing or screen joint.

c. Stab into float shoe.

d. Rig up circulating head to tubing. Circulate drilling mud at 220 to 250 GPM taking returns on the 5-1/2" $\times 8-5 / 8^{\prime \prime}$ casing annulus. Wash joint down to floor. Hang off casing on rig floor. Hang off tubing with concentric slips.

e. Pick up next joint of tubing on elevators and carry to near crown.

f. Pick up next joint of casing or screen using air line. Push out bottom of tubing joint so that casing can be slid up over tubing while being picked up.

8. Make up tubing joint.

h. Make up casing or screen joint.

i. Wash down joint as in (d) above.

j. Repeat steps (e) to (i) until pipe is run to TD.

NOTE: If screen is still being run in hole, tubing will have to be in 20 foot sections to match sceen lengths ( 10 a $20 \mathrm{ft} j \mathrm{jt}$ ).

32. Lay down casing elevators.

33. Inflate external casing packer by pumping water down $3 / 8$ " line at $1 / 4$ GPM until reaching 500 psi. DO NOT EXCEED 1000 PSI. Shut-in 3/8" needle valve. Install pressure gage and needle above the needle valve so that the ECP element pressure can be observed and recorded.

34. Grout 5-1/2" casing in place using procedure given in Casing Running and Cementing Procedure (pg. 22). Shut well in 8 hours to wait on cement. (Minimum compressive strength $=500 \mathrm{psi}$ ) 
35. Empty and flush steel mud tanks until clean. Drain and flush all lines, headers, valves, and pumps. Fill steel pits with clean, fresh water.

36. Pick up tubing tongs, elevators, and slips. Pick up 2-3/8, $4.7 \mathrm{lbs} / \mathrm{ft}, 8 \mathrm{RD}$, EUE tubing.

37. Run in hole with stab-in joint (see Figure No. 10), and 516 feet of tubing. Run centralizers and opposed cup packers every 60 feet for the first 300 foot of tubing. Pick up casing pack off on last joint. Set casing pack off and stab into float shoe.

38. Displace mud, remove mud cake, and Initiate well development by reverse circulation of freshwater past liner at 300 GPM. Circulate down the casing-casing annulus and take returns on the $2-3 / 8^{\prime \prime}$ tubing. Slower initial rate may be necessary to displace viscous mud pill. Circulate until pressure exceeds 70 psi plus friction or all fluid returns are clear. If fluid returns are clear slowly increase rate to $400 \mathrm{GPM}$. Circulate until pressure exceeds $100 \mathrm{psi}$ at $300 \mathrm{GPM}$ or $140 \mathrm{ps} 1$ at $400 \mathrm{GPM}$ or all fluid returns are clear. Slowly shut down pumps.

39. Pull out of hole with tubing and stab-in joint.

40. Go in hole with jetting sub and 2-3/8" tubing. Pick up casing packoff on last joint. Pack off casing and run jetting sub to TD.

41. Rig up power swivel and water truck. Cross stake and chain all pressure 1ines. If necessary, change out pump liners to obtain rate and pressure. Pressure test all pressure lines to 1500 psi.

42. Jet screen clean and finish well development using freshwater filtered to 5 microns (use cartridge filter pack). Jet at 20 to $30 \mathrm{GPM}$ and 1,200 psi. Take returns on the tubing-casing annulus. Begin jetting from the bottom up at 3 to 4 feet per minute with 
rotation. Continue jetting until reaching the top of the screen at $251 \mathrm{ft}$.

43. Go back to TD (546 ft) at 5 to 10 feet per minute while continuing to jet and rotate.

44. Pull out of hole with $2-3 / 8^{\prime \prime}$ tubing and jetting tool. Lay down tubing elevators and slips.

45. Go in hole with port shifting tool on $2-3 / 8^{\prime \prime}$ tubing. Close casing port collar at $219 \mathrm{ft}$. Pull out of hole with tubing and shifting tool.

46. Go in hole with bull plug, $2 \mathrm{ft}$ pup jt with centralizer and orifice, 1 jt fiberglass tbg, 2 ft jt with centralizer, opposed cup packer, 1 ft fiberglass tbg, 2 ft sub with centralizer and orifice, 1 ft fiberglass tbg, 2 ft $\mathrm{jt}$ with centralizer, opposed cup packer, 1 jt fiberglass tbg, 2 ft pup $j t$ with centralizer and orifice, $1 \mathrm{jt}$ fiberglass tbg, $2 \mathrm{ft} j \mathrm{jt}$ with centralizer, opposed cup packer, 1 jt fiberglass tbg, 2 ft sub with centralizer and orifice, 1 jt fiberglass tbg, 2 ft $j t$ with centralizer, opposed cup packer, $1 \mathrm{jt}$ fiberglass tbg, 2 ft sub with centralizer and orifice, $1 \mathrm{jt}$ fiberglass tbg, $2 \mathrm{ft} \mathrm{jt}$ with centralizer, opposed cup packer, and fiberglass tubing to surface. Hang off tubing with bull plug at least $5 \mathrm{ft}$ off bottom and not more than $15 \mathrm{ft}$ off bottom. Monitor and record slackoff weight at each joint going in hole. Figure No. 12 gives the dimensions of the cetralizer sub. Figure No. 13 gives the dimensions of the centralizer and orifice sub. Figure No. 14 is a schematic of the completion system to be installed in the well.

NOTE: use only strap wrenches for making up and breaking out fiberglass joints.

47. Turn well over to plant personnel for injection piping. 


\section{MUD PROGRAM}

The proposed drilling fluid for the DuPont AMH No. 1 is a bentonite polymer freshwater system for both the vertical section and the horizontal section. In the vertical section, mud properties will be as conventionally used in area water wells and monitoring wells. Permission has been granted by DHEC for the use of EZ MUD (a PHPA or partially hydrolyzed polyacrylamide) and QUIK TROL (an organic polymer). If necessary, the PHPA may be used to formulate high viscosity sweeps to assist in hole cleaning and borehole stabilization in the 16 inch vertical hole.

In the horizontal section, the basic drilling mud will consist of 10 lbs/bbl (23.8 lbs/100 gals) bentonite, 87.3 lbs/bbl (208 1bs/100 gals) sized calcium carbonate, and freshwater. The calcium carbonate is needed to provide a weight of $9.5 \mathrm{ppg}$ to keep the horizontal wellbore open. The calcium carbonate will also provide a bridging material to reduce fluid loss. QUIR TROL will be added to the base system for suspension of weight material and to provide a tough pliable mud cake to resist erosion by turbulent flow. Turbulent flow will be used throughout drilling to ensure the horizontal section is clear of cuttings. The horizontal section will be cleaned out using turbulent flow prior to pulling drill pipe out of the horizontal section. A high viscosity pill will be left on bottom. It is imperative that this pill have a 9.5 ppg mud weight, excellent fluid loss control, and a moderate to high viscosity.

Solids control equipment for the vertical section of the hole will consist of a double section dirt pit as normally used in area wells. Prior to drilling the horizontal section, additional oilfield solids control equipment will be rigged up in conjunction with the dirt pits. The solids control equipment will be used to remove the drill solids which tend to absorb the polymers without yielding appropriate mud properties. This equipment will consist of a Derrick Flo-Line Cleaner or an 8 cone hydrocyclone manifold discharging into the mixing section 
of a 4 compartment steel pit. All three sections will have continuous agitation. The pit will be manifolded to provide a mixing section, a slug pit, and a suction pit. A schematic of the mud equipment and solids control equipment is shown in Figure No. 8. A 200 bbl drill water tank will be kept full at all times in the event of whole mud losses.

Avoid excessive penetration rates in both the vertical and horizontal sections of the hole. The maximum allowable penetration rate for the vertical section will be calculated on site based on the mud pump capacities. The maximum penetration rate for the horizontal section will be $6 \mathrm{ft} / \mathrm{min}$ at a circulation rate of 140 to $180 \mathrm{GPM}$.

The mud company will provide a full mud kit with 6 speed rheometer at location. This equipment will be used to ensure that optimum mud properties are maintained during drilling and completion of the horizontal section. 
MUD PROGRAM

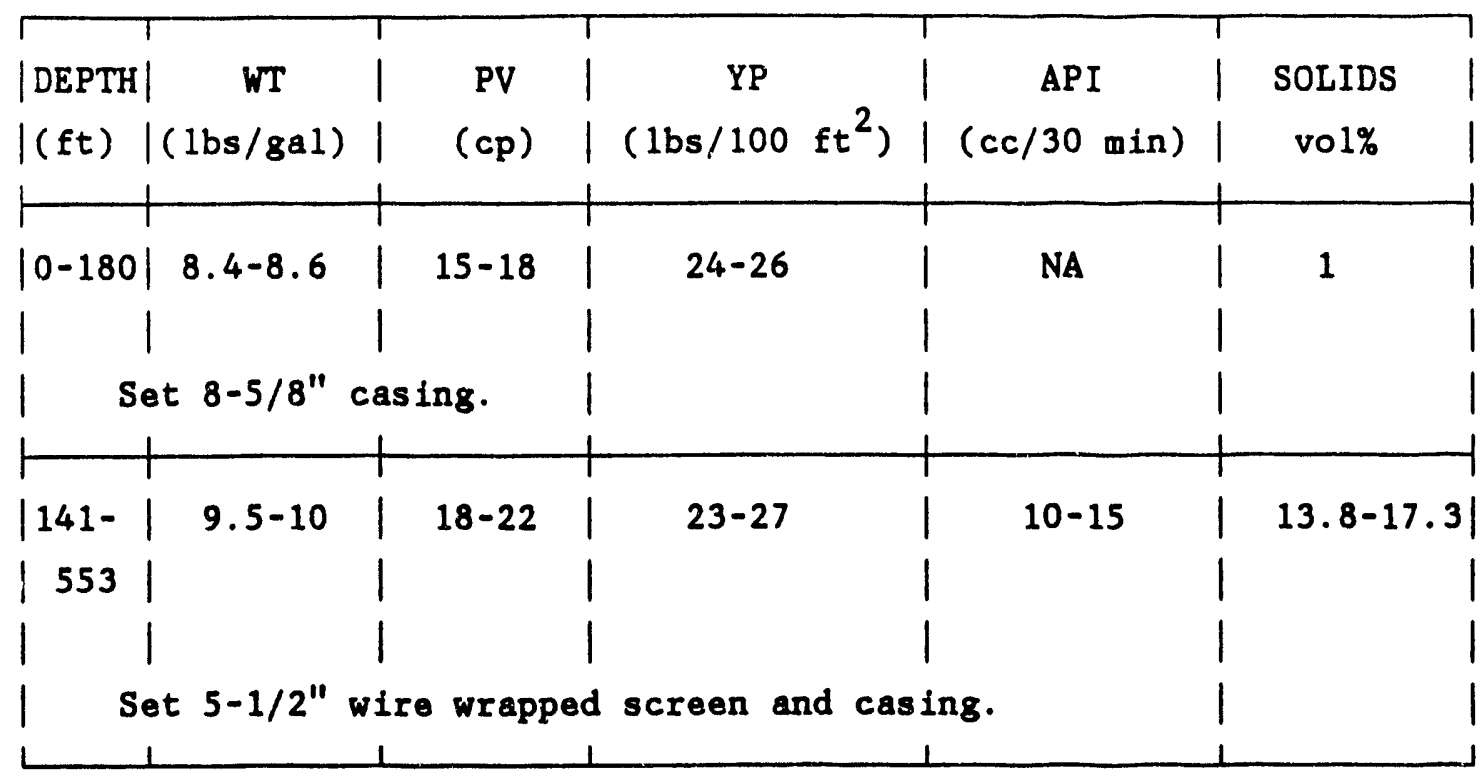

MUD FORMULATION

0 - 180 FT (VERTICAL SECTION)

20-25 ppb bentonite (Aquage1)

$141-553$ FT

8-10 ppb bentonite (Aquage1)

0.25 ppb Quik Trol

87 ppb calcium carbonate (Baracarb 5,50,150,600)

\section{SWEEP FORMULATION}

0 - 180 FT (VERTICAL SECTION)

1 qt. PHPA polymer (EZ Mud) down drillpipe at connection

NOTE: Drill pipe pressure may decrease during pumping of the sweep due to friction reduction properties of the polymers.

\section{HIGH VISCOSITY PILL FORMULATION}

$141-553$ FT

8-10 ppb bentonite

0.5 ppb Quik Tro1

87 ppb calcium carbonate (Baracarb 5,50,150,600) 


\section{CASING RUNNING AND CEMENTING PROCEDURE}

\section{8-5/8" Casing}

A. Drill to 180 feet with 46 " bit. C\&C and POOH. Record circulating time before $\mathrm{POOH}$ and time at start off bottom.

B. RU electric line. Log hole. POOH and rig down electric line.

C. GIH w/ open ended drill rods. Break circulation. Plug back with sand to $39 \mathrm{ft}$ above lateral depth specified by geologist. (Assumes that the bottom of the window is $1 \mathrm{ft}$ above the bottom of the joint. Use actual measurement to adjust.) POOH.

D. RU casing lift equipment, slips, and welding equipment.

NOTE: Be sure all 8-5/8" casing has been inspected, drifted $\left(7-3 / 4^{11} \times 6^{\prime 7}\right)$, tallied, and steam cleaned. Weld on casing stops (as shown in Figure No. 14) prior to running in the hole.

\section{CASING PROGRAM}

$\begin{array}{lllll}\text { DEPTH } & \text { SIZE } & \text { WE TGHT } & \text { SCH } & \text { ID } \\ 0-141^{\prime} & 8-5 / 8^{\prime \prime} & 28.55 & 40 & 7.981^{\prime \prime}\end{array}$

CENTRALIZERS: " 2 big hole centralizers per jt with welded stop collars

E. Run whipstock joint and casing to TD ( $141 \mathrm{ft}$.$) . Orient$ whipstock to $237.87^{\circ}$ (ref TN) while running pipe. Tag bottom and pick up casing weight $( \pm 3000 \mathrm{lbs})$. Hang off casing on rig floor. Record time when casing hung off. 
F. RIH w/ drill rods to top of whipstock ( $-131 \mathrm{ft}$ ). Pick up casing packoff on last joint in hole. Tack casing shoe using Cal-Seal. Batch mix 16 sacks Cal-Seal using 4.8 gallons of freshwater per sack. Ensure that mix water temperatures are below $80^{\circ} \mathrm{F}$ to prevent flash setting. (Note: Sample testing for pumpability will be performed on site.) Using balanced plug method, spot Cal-Seal on bottom. (Casing-Hole Annulus $0.1772 \mathrm{bbls} / \mathrm{ft}$ or $0.9947 \mathrm{cu} \mathrm{ft/ft;}$ Casing Capacity $.0621 \mathrm{bbls} / \mathrm{cu} \mathrm{ft}$ or $0.3489 \mathrm{cu} \mathrm{ft} / \mathrm{ft}$; Cal-Seal Yield $1.24 \mathrm{cu} \mathrm{ft} / \mathrm{sx}$; Cal-Seal Density $15.1 \mathrm{ppg}$ )

G. POOH w/ drill rods.

H. Allow Cal-Seal to set 1 hour.

I. GIH w/ muleshoe, 2-3/8", $4.7 \mathrm{lbs} / \mathrm{ft}, 8 \mathrm{rd}$, EUE tremie pipe. to top of Cal-Seal (expected at $=126 \mathrm{ft}$ or is $\mathrm{ft}$ above PBTD).

J. Grout casing in place by continuous pumping down tremmie pipe. Pump $20 \%$ excess to displace contaminated cement from annulus. Record time at beginning and end of pumping cement.

Slurry: $\quad$ Class A $+2 \% \mathrm{CaCl}_{2}$

Volume: $90 \mathrm{cu} \mathrm{ft}+20 \%$ excess $=108 \mathrm{cu} \mathrm{ft}(92 \mathrm{sx})$

Density: $15.6 \mathrm{ppg}$

Yleld: $\quad 1.18 \mathrm{cu} \mathrm{ft/sk}$

Water: $\quad 5.2 \mathrm{gals} / \mathrm{sk}$

NOTE: 1 sk $=941 \mathrm{bs}$ 
Cement samples will be collected and saved during the job. These may be used to determine adequate wOC time.

K. Pull tremmie pipe. (NOTE: expected thickening time of cement is $1: 30$ )

L. If necessary, perform top job using tremmie pipe and the same cement design. The DuPont representative will provide the volumes necessary to preform the top job.

M. Allow grout to set a minimum of 8 hours prior to drilling out. The minimum allowable compressive strength is 500 psi.

\section{5-1/2" Casing - Running Casing}

A. Drill curve and lateral section $w / 6-1 / 4^{\prime \prime}$ bit to a measured depth of $553 \mathrm{ft}$. C\&C and POOH. GIH \& survey hole. POOH.

B. GIH w/ 7-3/4" hole opener (Drillex 6-7/8" Simplex bit), wiggly drill collars, and drill pipe. Open hole from 6-1/2" to 7-3/4" diameter over the open hole interval(141 ft to $553 \mathrm{ft}$ ). Limit rate of penetration to $6 \mathrm{ft} / \mathrm{min}$ ( 5 minutes per $30 \mathrm{ft}$ joint) to allow filter cake to redevelop. Slower penetration rates may be necessary. Circulate at 225 to $250 \mathrm{GPM}$ (2.3 fps $\leq \mathrm{AV} \leq 2.6 \mathrm{fps}$ ) while opening the hole.

C. Circulate and condition the hole as follows.

1. Pump drilling mud at $300 \mathrm{GPM}$ ( $\mathrm{AV}=3 \mathrm{fps}$ ) for 40 to 60 bbls ( 1700 gals to $2500 \mathrm{gals}$ ).

2. Pump 10 bbl viscous sweep (add suction line volumes to sweep volume). Attempt to maintain a high circulation rate. Limit surface pressures to $900 \mathrm{psi}$.

3. Pump 40 bbls of drilling mud at 300 GPM.

4. Spot viscous pill on bottom ( $25 \mathrm{bbls}$ or $1100 \mathrm{gals}$ ) 
D. POOH and rig down Eastran Christensen, tongs, bails, and elevators.

E. Rig up bails and elevators for 5-1/2" casing. Have two sets of elevators on the rig floor. Replace bottom bail keeper bolt (both sides) with equivalent diameter and strength cotter pin and keeper on both sets of elevators.

\section{CASING PROGRAM}

$\begin{array}{lcccccc}\text { DEPTH } & \text { SIZE } & \text { WEIGKT } & \text { GRADE } & \text { ID } & \text { DRIFT } & \text { TYPE } \\ 0-251^{\prime} & 5-1 / 2^{\prime \prime} & 14 & \text { H-40 } & 5.012^{\prime \prime} & 4.887^{\prime \prime} & \text { CSG }\end{array}$

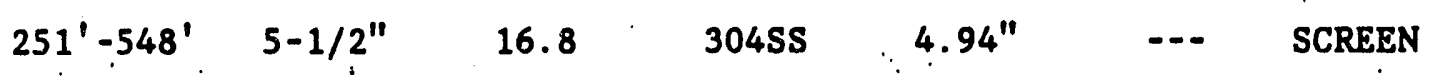

All casing, screen, and associated equipment will be plain end with a $45^{\circ}$ bevel for welding. All joints will be less than 25 feet in length ( $r i g$ clearance is $25 \mathrm{ft}$. ). Welding procedures will be according to SRP procedure by plant approved welders.

NOTE: Be sure al1 5-1/2" screen has been inspected, gapped $\left(0.010^{\prime \prime}\right)$, drifted $\left(4.94 \times 6^{\prime \prime}\right)$, and steam cleaned.

NOTE: Be sure all 5-1/2" casing has been inspected, drifted (4.887" $\left.\times 6^{\prime \prime}\right)$, tallied, and steam cleaned. Weld on casing centralizer stops (as shown in Figure No. 14) prior to running in the hole. Note that bottom 2 joints of casing w11 not have any centralizers.

F. Weld float shoe to first joint of screen on laydown. Pick up screen using elevators and tail rope. DO NOT ALLOW SCREENS TO STRIKE RIG STRUCTURE AS DAMAGE TO SCREEN GAPPING WILL RESULT. 
G. Hang off screen on rig floor with elevators. Release elevators from bail using cotter pins. (Equip floor hands w/ needle nose pliers). Rig up second set of elevators to bails.

H. Continue running screen using procedure above and butt welding all joints. Run 295 ft of wire wrapped rod based stainless steel screen. NOTE: Screen will set down on whipstock at $130 \mathrm{ft}$. Work screen gently through angle building section of hole. Surface weight will decrease due to drag in open hole.

I. Weld $30 \mathrm{ft}$ of casing to top of screen. Weld port collar to top of joint and run with ports open.

J. Weld external casing packer to top of port collar. Weld on next joint of casing but do not run in hole.

R. Install bottom fitting to ECP port and inline check on $3 / 8^{\prime \prime}$ 304 stainless steel control line. Fill line with water.

L. Install $3 / 8^{\prime \prime}$ tubing with check valve in inflation port on ECP. Clamp 3/8" tubing to casing using 3 bands in the first 10 feet above the ECP. Orient the $3 / 8^{\prime \prime}$ tubing on the high side of the hole $\left(237.87^{\circ}\right.$ referenced to True North).

M. RIH 10 feet. Clamp on 2 strings of 3/4" Intergal Joint PVC 10 feet above top of ECP. Clamp bottom 5 feet of $3 / 4^{\prime \prime}$ stings to casing using 3 bands. Do not at:cempt to use the same bands securing the $3 / 8^{\prime \prime}$ to secure the $3 / 4^{\prime \prime}$ tubing.

N. Continue in hole with wolded foints on casing. Install associated casing equipment according to the following guidelines :

(1) Install centralizers underneath the three external tubing strings. 
(ii) Clamp the $3 / 8^{\prime \prime}$ string to the casing using 1 band $12^{\text {" }}$ to 18 " above the casing joints and 1 band in the middle of the joint. Orient the tubing to the high side of the hole $\left(237.87^{\circ}\right.$ ref TN).

(iii)Clamp the two strings of $3 / 4^{\prime \prime}$ tubing to the casing using 1 band $12^{\prime \prime}$ to $18^{\prime \prime}$ below the casing joints and 1 band in the middle of the joint. Keep the middle joint band 1 to 2 feet from the $3 / 8^{\prime \prime}$ tubing clamps. Orient the strings to the high side of the hole $\left(237.87^{\circ}\right.$ ref TN).

(iv) Insure that all control lines pass through spaces in stop blocks for centralizers.

0 . Run $198 \mathrm{ft}$ of 5-1/2", $14 \mathrm{lb} / \mathrm{ft}, \mathrm{H}-40$ casing from the top of the ECP to surface. DO NOT RUN FLOAT SHOE TO TD. Run casing to 5 feet off bottom. CAUTION: FILI MAY BE PRESENT.

\section{5-1/2" Casing - Grouting Casing}

A. Manifold the two strings of 3/4" IJ PVC together at the surface and tie to mud pump for grouting.

B. Install needle valve, tee, pressure gage, needle valve, and plumbing to pump on $3 / 8^{\prime \prime} 1$ ine.

C. Inflate ECP by pumping water at $1 / 4$ GPM down the $3 / 8$ " tubing. Note and record pressures, rates, and times during the inflation of the ECP. A final pressure of 500 psi on the element will be required to provide zonal isolation. DO NOT EXCEED 1000 PSI DURING INFLATION.

D. Grout the 5-1/2" casing in place by continuous pumping down manifolded 3/4" PVC tremmie pipes. Pump 20\% excess to displace contaminated cement from annulus. Record time at beginning and end of pumping cement. 
Slurry: $\quad$ Class $\mathrm{A}+2 \% \mathrm{CaCl}_{2}$

Volume: $\quad 35 \mathrm{cu} \mathrm{ft}+20 \%$ excess $=42 \mathrm{cu} \mathrm{ft}(36 \mathrm{sx})$

Density: $\quad 15.6 \mathrm{ppg}$

Yleld: $\quad 1.18 \mathrm{cu} \mathrm{ft/sk}$

Water: $\quad 5.2 \mathrm{gals} / \mathrm{sk}$

NOTE: $1 \mathrm{sk}=94$ lbs

Cement samples will be collected and saved during the job. These may be used to determine adequate WOC time.

NOTE: expected thickening time of cement is $1: 30$

E. If necessary, perform top job using additional 3/4" IJ PVC tremmie pipe and the same cement design. The DuPont representative will provide the volumes necessary to perform the top job.

F. Allow grout to set a minimum of 8 hours prior to well development. The minimum allowable compressive strength is 500 psi. 
The specifications contained on this page are minimum requirements.

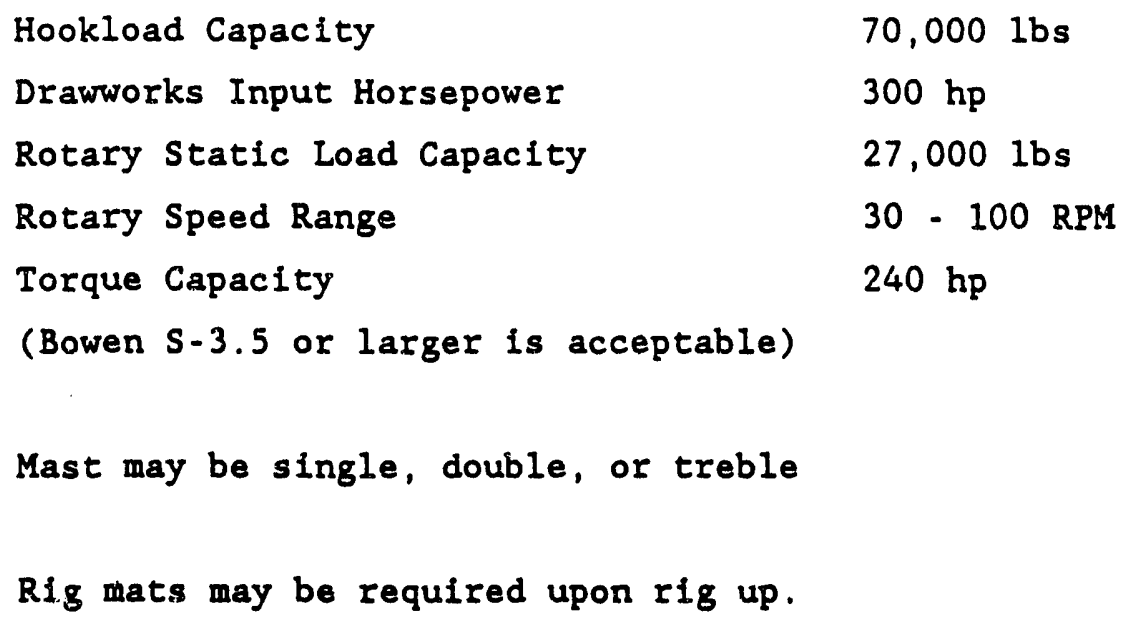


Figure 1. Xerox of map of western South Carolina and eastern Georgia. 


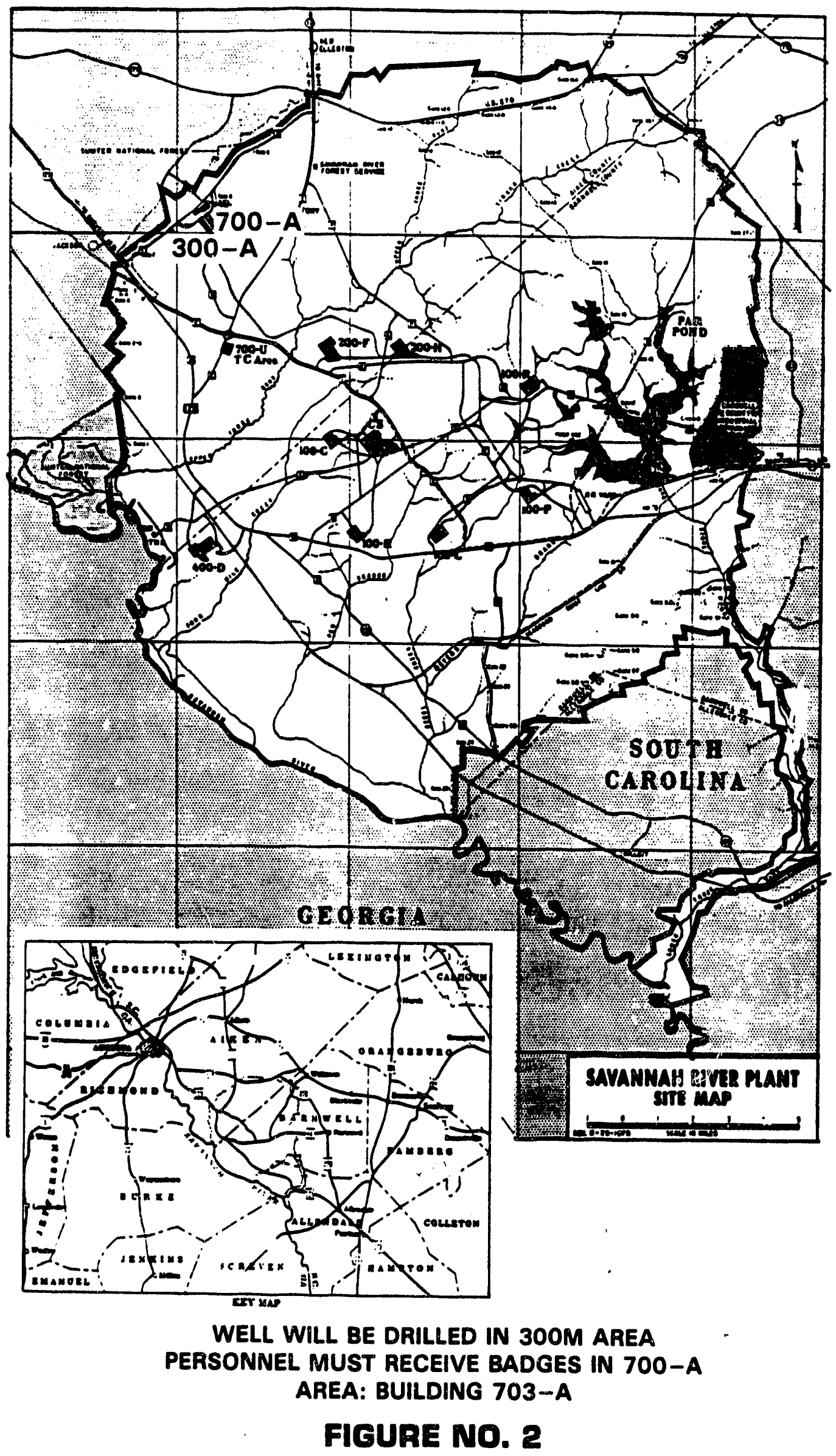


VELL: AUH NO.1

Location: MLaza3g, E498ge Sap coon

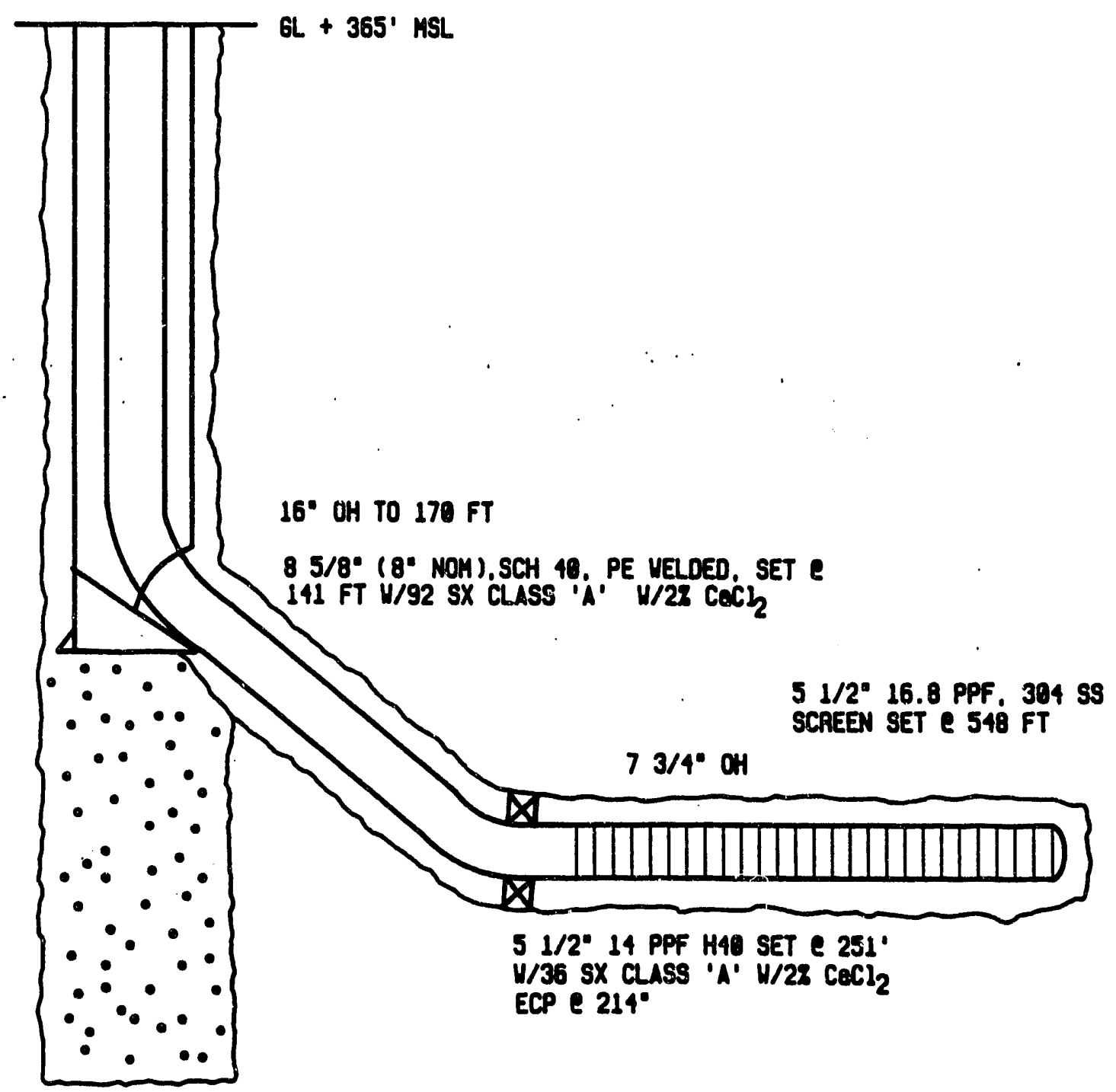

FIGURE NO. 4 


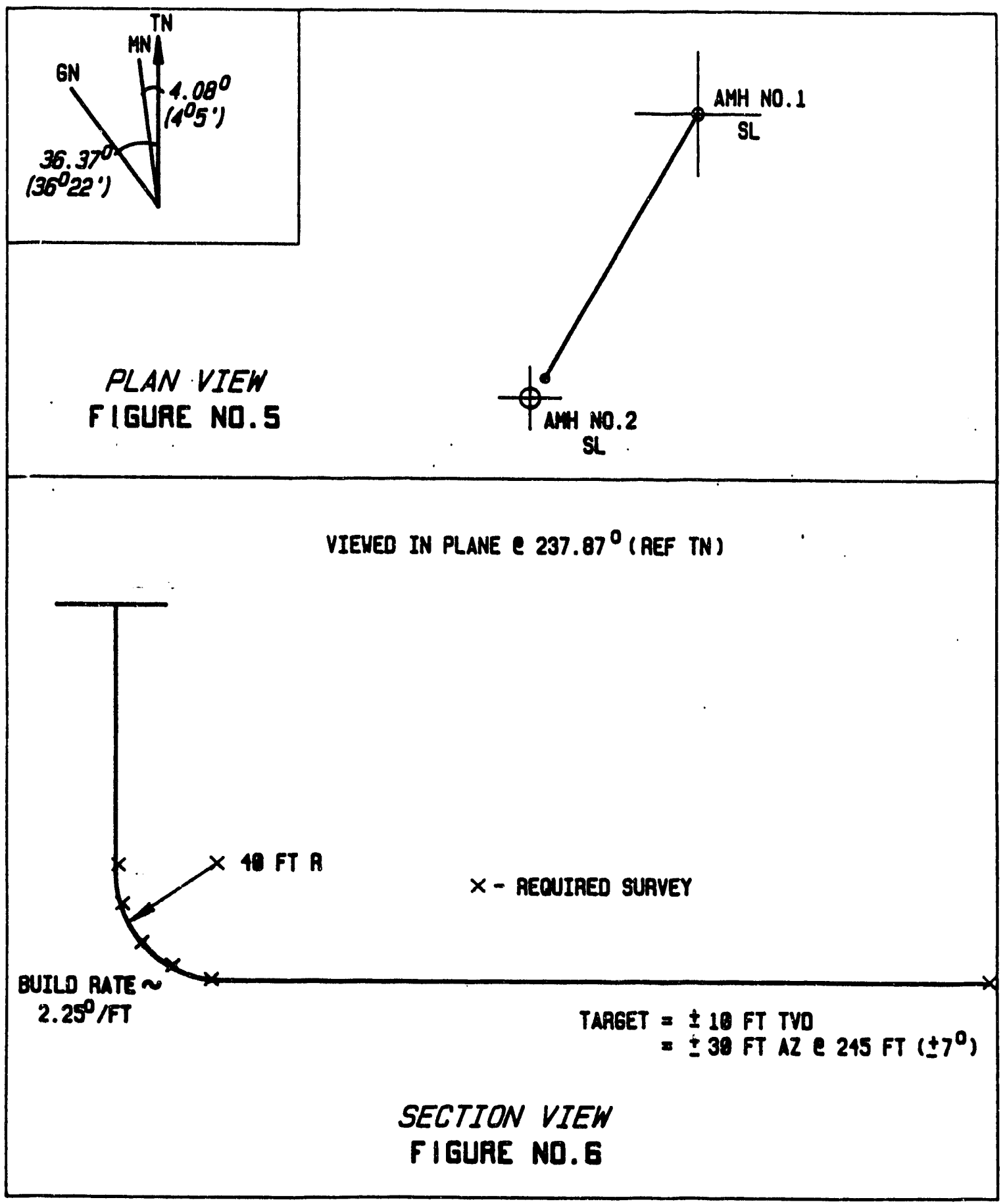




\section{DU PONT \\ CASING/WHIPSTOCK ASSEMELY}

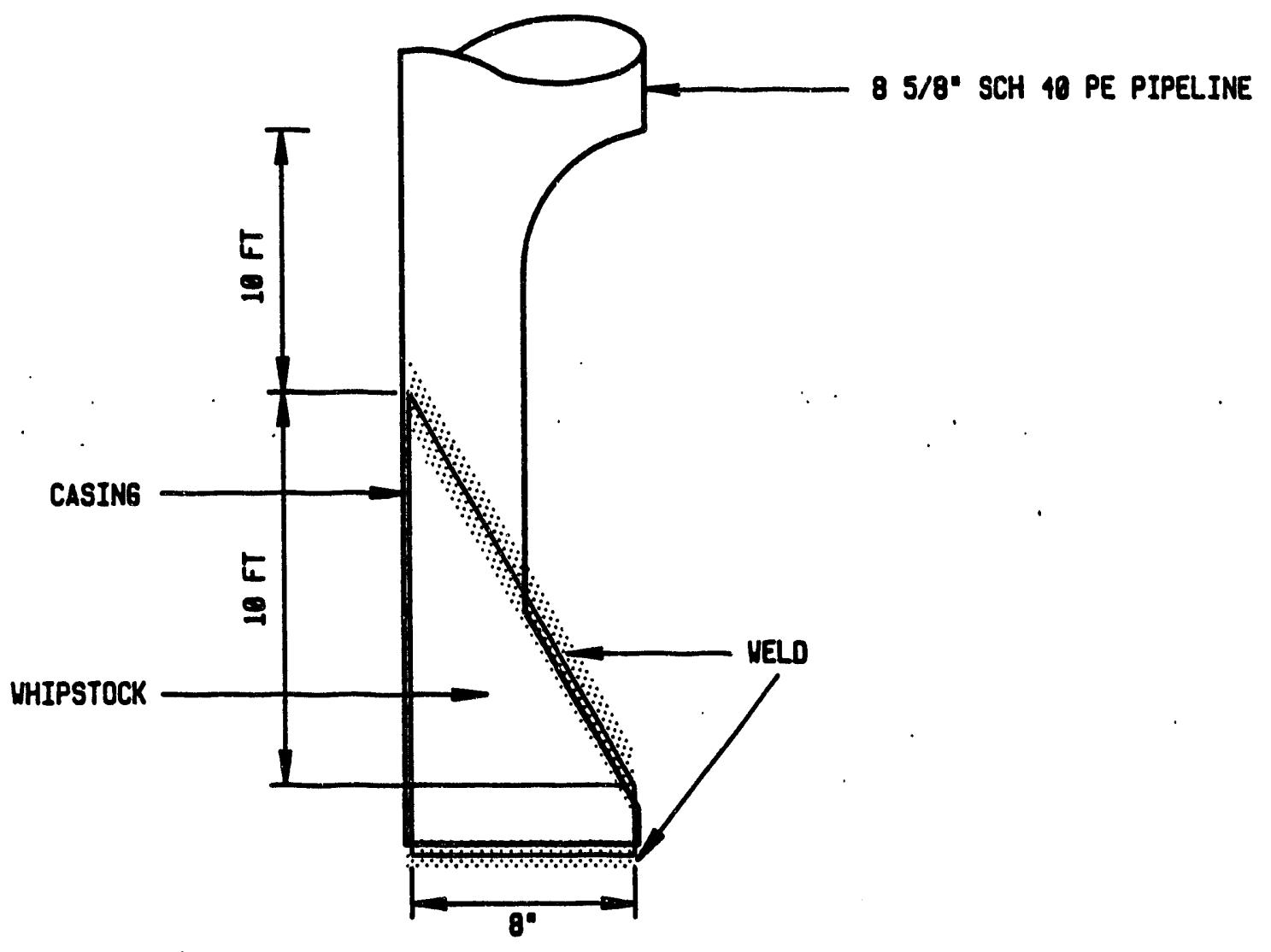

NOTE TOP OF NINDOW TO START 10 FEET ABOVE

TOP OF MHIPSTOCK. OPEN MINOON $180^{\circ}$.

CENTRULIZE MHIPSTOCK IN CASING.

THEN MED IN PLACE.

FIGURE NO. 7 


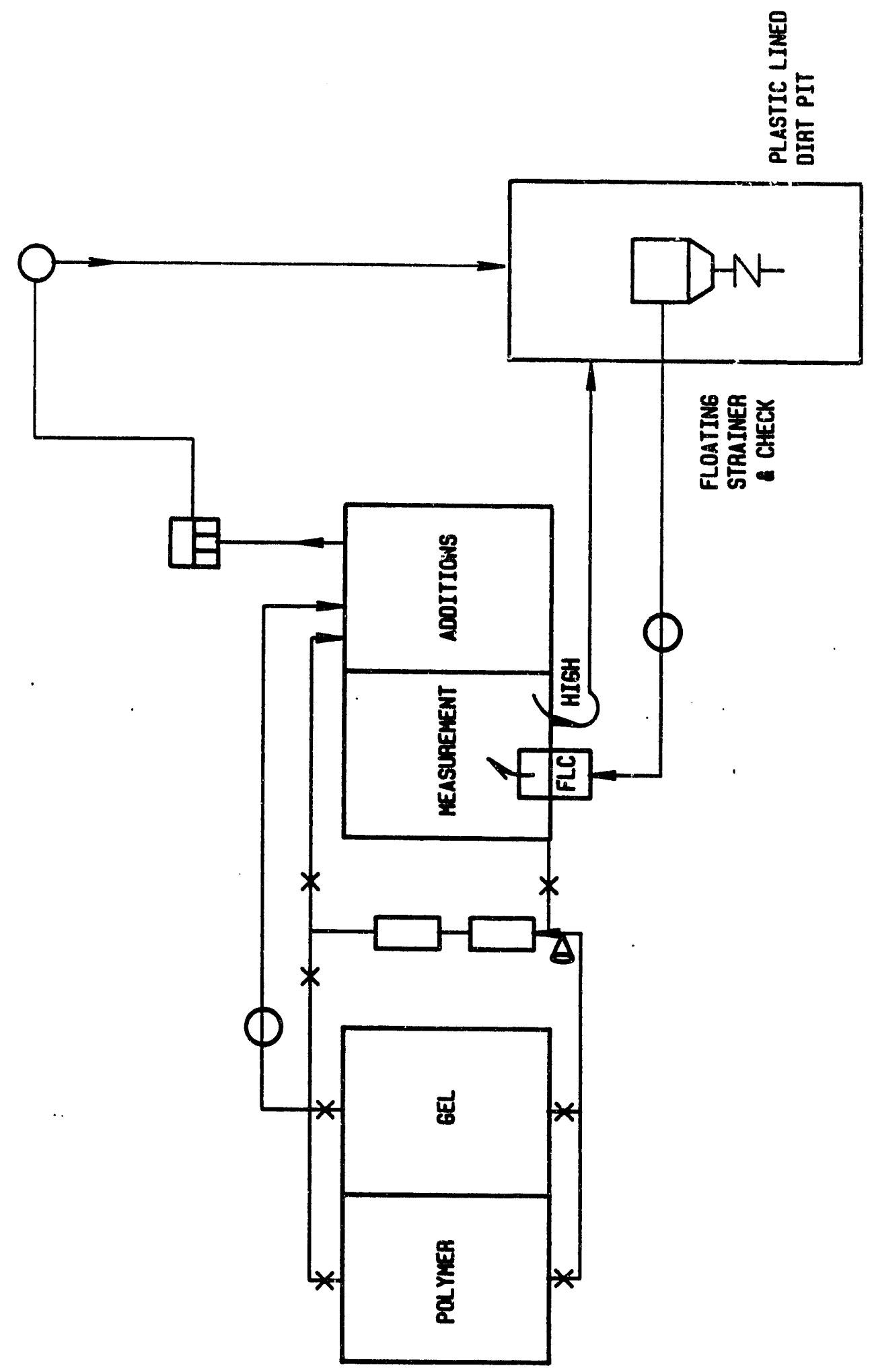

F IGURE NO.B 

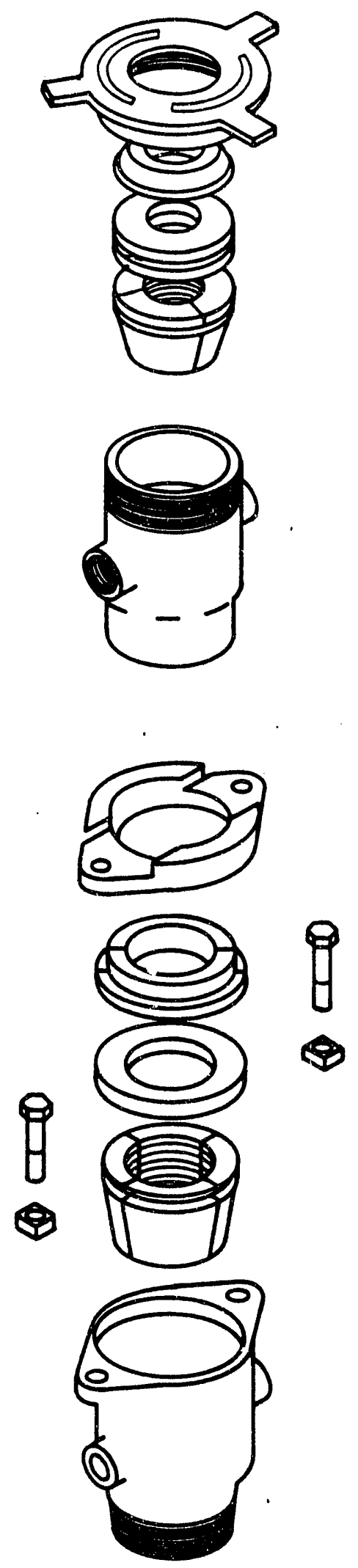

FIGURE NO. 9 


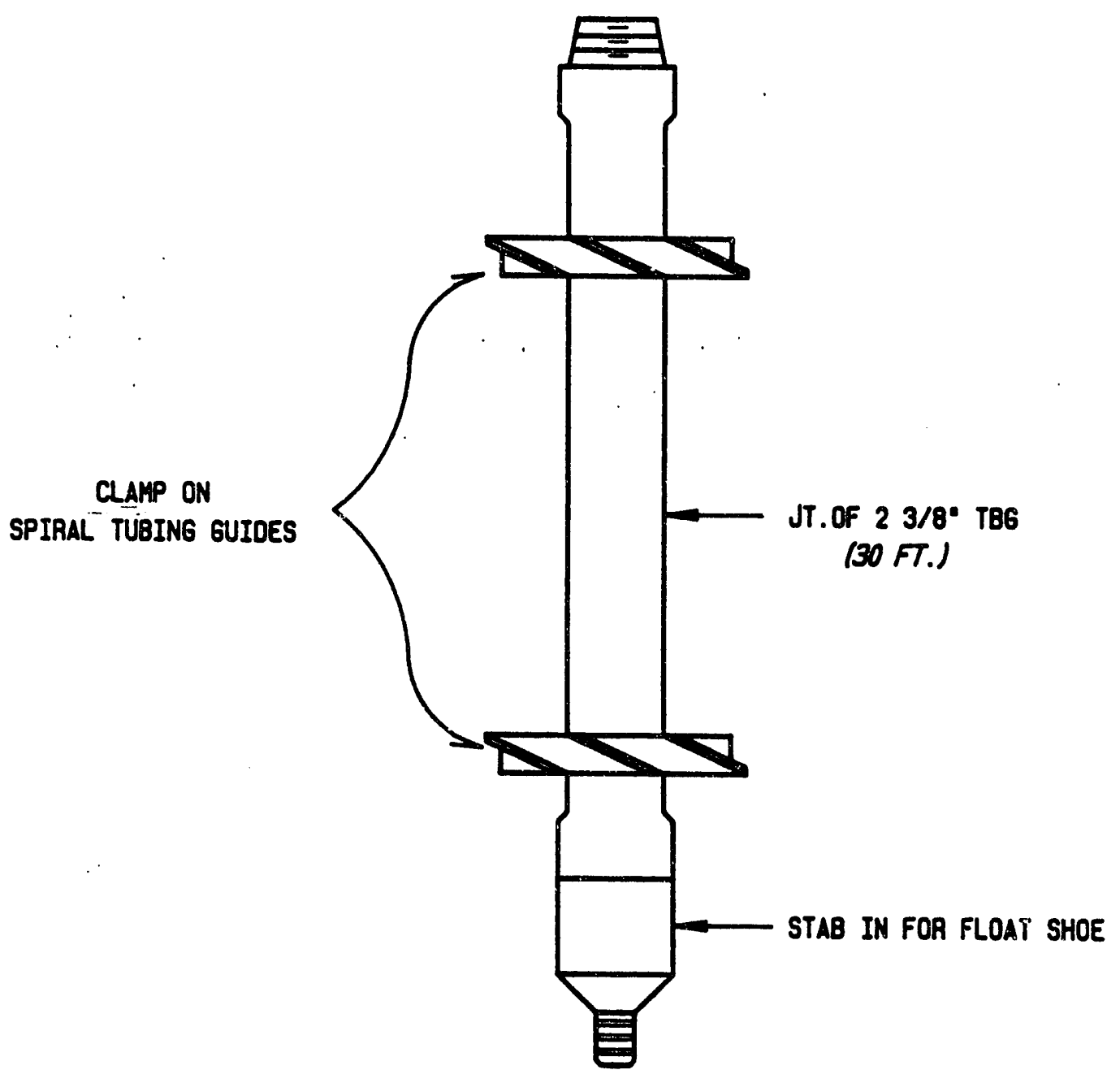

FIGURE NO.10 


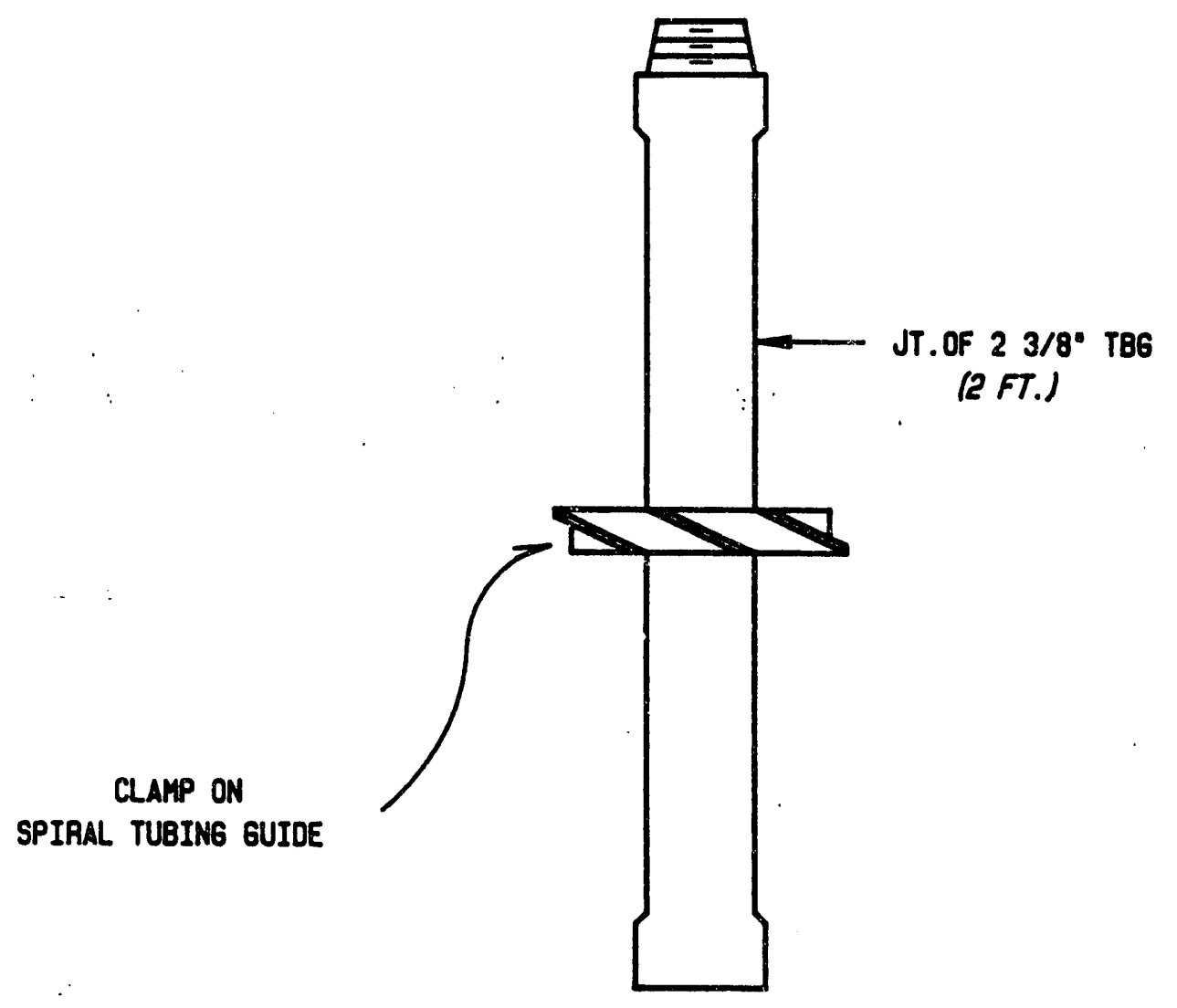

FIGURE NO.11

CENTRALIZER SUB 


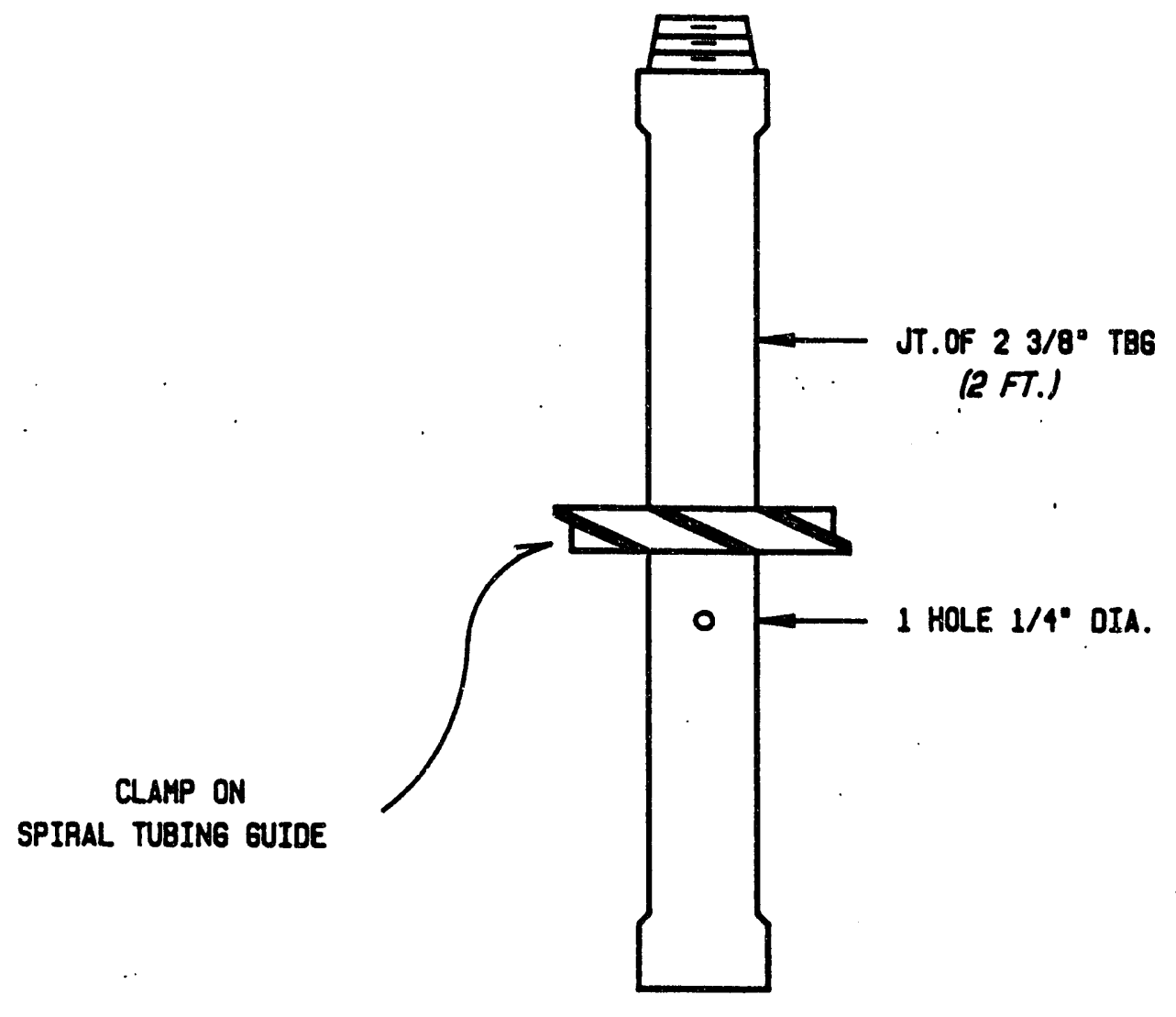

FIGURE ND. 12

CENTAALIZER AND DRIFICE SUB 

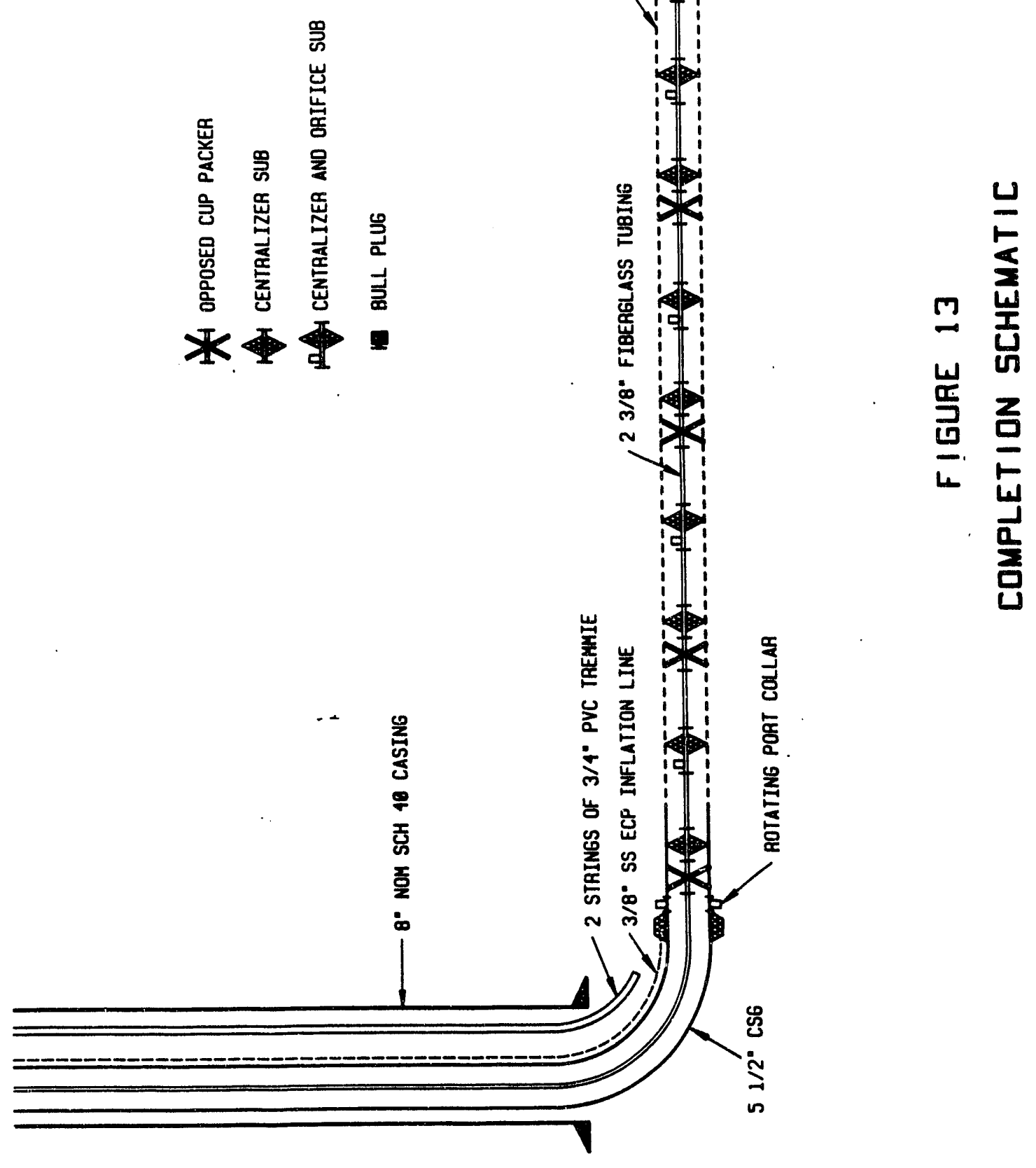


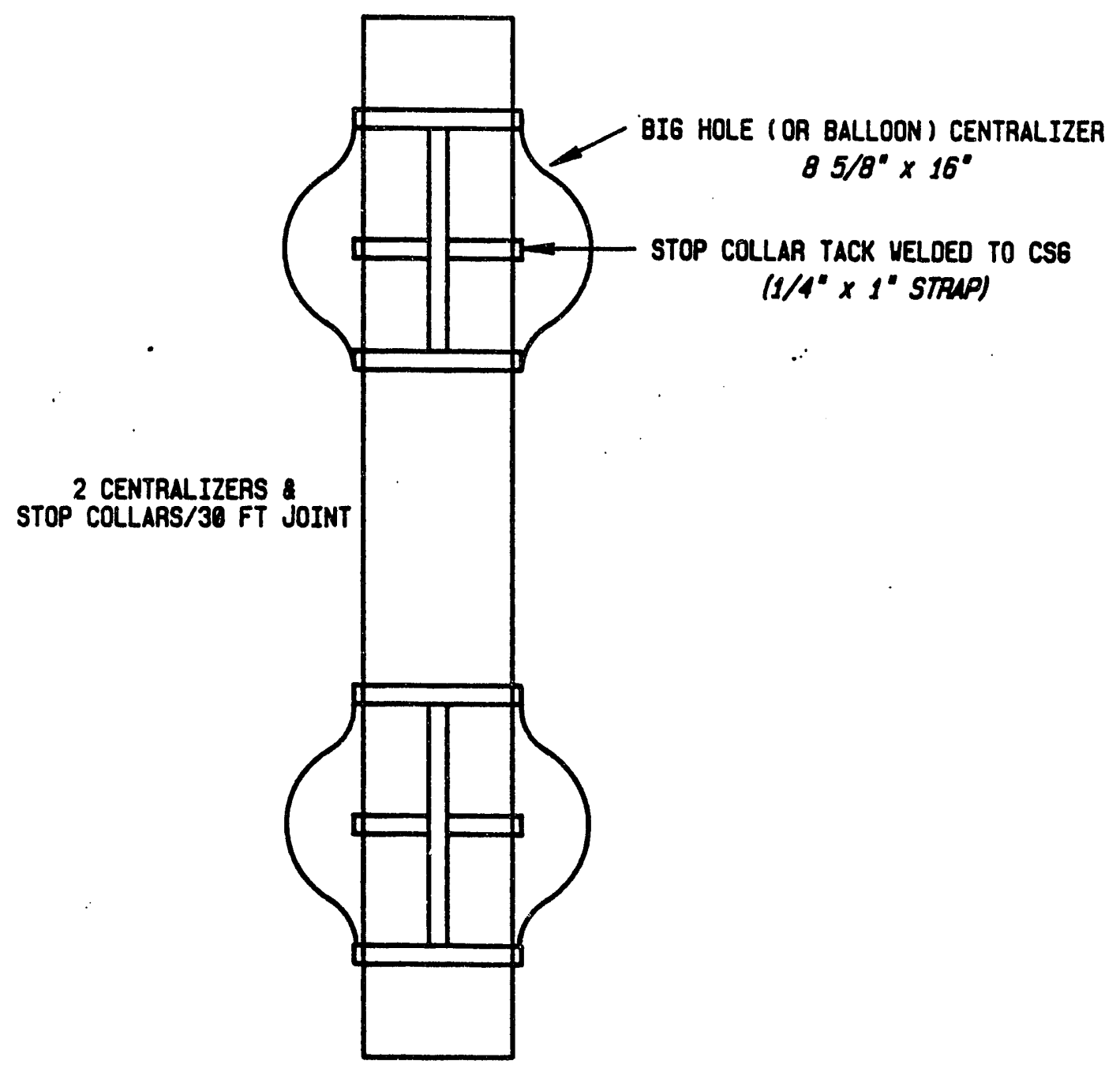

FIGURE NO. 14 
DRILIING PROGRAM

AMH NO. 2

AREA M

DU PONT SAVANNAH RIVER PLANT

AIREN, SC

Prepared by:

Edward G. Dew

Conoco PER

Approved by:

David H. Schwartz

Conoco PER

Approved by:

E. I. Du Pont de Nemours and Company 
E. I. Du Pont de Nemours \& Company, Inc. is committed to safety. The plant safety book w111 be followed. Section seven of the Conoco NAP Safety Manual, which pertains to drilling, will also be used as a guide. The Du Pont representative (Conoco supervisor) on location and plant safety personnel will monitor safety and provide input on those occasions where specific safety questions arise.

The drilling contractor will be required to meet all applicable OSHA requirements for equipment and personnel. The drilling contractor must provide only drill rig operators who have been certified by the State of South Carolina. The contractor must ensure that appropriate safety precautions are taken at all times. Prior to initiation of work, a safety briefing shall be given by plant safety personnel. The contractor must then demonstrate familiarity with applicable safety precautions. 


\section{REPORTS}

The experimental nature of this well requires that excellent records be maintained to document the drilling and completion of this well. All drilling logs, completion logs, and pressure charts shall be labelled with details explaining the particular operations performed. Details shall include the reason for the operation, scales, notations of procedural steps, and alterations from the approved procedure. A11 original recordings (including tally books and daily reports)will be saved and filed for future reference. Detailed End of Well reports will be required of all service companies.

This well will be a team effort by all personnel on the rig site. The following division of reporting responsibilities is made to clarify the requirements of each individual and to decrease the opportunities for confliat.

IADC Tour Reports (which will be supplied by Conoco) are to be completed at the end of each tour and signed by the drilling contractor. The drilling contractor will be required to keep an accurate record of all equipment dimensions during vertical drilling operations and during completion and development operations.

The directional services company will provide at well site, a $30^{\prime \prime} \mathrm{x}$ 40 " plot of the proposed directional plan. This plot will include both a plan view and a section view. The plot will be posted in the DuPont representative's traller. The directional company will post all surveys on the plot to ensure that a detailed, current comparisnn between the well plan and actual performancs is maintained. The directional company will keep a detailed record of all equipment dimensions in the hole during their active operations.

The solids equipment/mud hand will run mud checks and fill out mud check sheets. He w111 also be responsible for ensuring proper mud additions are made (with the DuPont representative's approval) and the solids control equipment is in proper operating condition. The DuPont 
representative will post morning reports for DuPont and Conoco. He will also keep duplicate records of all equipment in the hole and make the necessary calculations for on site modifications to the proposed well plan. It will also be his responsibility to compile the end of well report which will incorporate and summarize those supplied by the contractors and service companies. 


\section{PURPOSE}

The drilling and completion of the AMH No.1 and AMH No.2 are part of continued experiments to test the feasibility of vacuum extraction methods to recover volatile hydrocarbons from an aquifer. In this phase of the project, two horizontal wells will be drilled in the same vertical plane. It is the intent that the deeper well (AMH No. 1) will be located below the contaminated portion of the aquifer which is approximately the top 55 feet below the water table. The second well (AMH No. 2) will be located approximately 50 feet above the water table in the Vadose zone. Upon completion, air will be injected into the AMH No.1 at a rate up to 900 to 1000 cubic feet per minute. AMH No. 2 will be subject to a ..... approximately the same rate as the injection rate in the AMH No. 1. The agitation and additional. surface area created by blowing the air through the water will release additional volatile hydrocarbons.

Further testing may be performed in a second phase using the horizontal injector (AMH No. 1) and the three existing vertical Vadose zone wells (VB Nos. 1,2, and 3). Air injection will continue from AMH No. 1 and the vertical wells will attempt to produce air at a rate similar to the injection rate. Various configurations may be used to provide a comparison between the efficiency of the horizontal vacuum extraction well and the vertical vacuum extraction wells. 
Objective: Drill and complete a horizontal test well above the water table. The subject well will be completed with a wire wrapped, rod based screen in the 300 foot long horizontal section. Total measured depth is anticipated to be 449 feet with a total vertical depth of 75 feet. Total horizontal displacement is expected to be 350 feet. The subject well will be used as an air infection well in the experimental vacuum evacuation tests. A horizontal air injection well is also part of this project and is covered by the AMH No. 1 wellplan.

Location: . Aiken County, South Carolina

*Latitude - 33.334183

*Longitude - 81.735373

*SRP Coordinates:

* N 102741

* E 49765

Directional: Magnetic Declination $-4^{\circ} 5^{\prime} \mathrm{W}$ of true $\mathrm{N}$ (as of Jan 29, 1988); Rate of change $=8.1^{\prime} \mathrm{W} / \mathrm{yr}$

Local Grid (SRP Grid) North $-36^{\circ} 22^{\prime} \mathrm{W}$ of true N

Elevation: tGround Level about $365^{\prime}$ above Mean Sea Level (MSL)

Water Table: 235' above Sea Level

*NOTE: The proposed wellsite will be surveyed. These values may change based upon the exact well position. 


\section{DRILLING PROCEDURES}

1. Location Preparation - The location shall be built according to specifications in DPSOP 254, Revision 0, Chapter 5, Sections B.4 and B.S. The areal extent of the location shall be sufficient to provide space for the following equipment: rig, two flatbed trailers (pipe and EC eyuipment), water storage tanks (or access to pit itr water haulers), mud pumps, four section steel ml tank, organized storage of miscellaneouss subs and wellhead equipment, as well as space for mud product storage (palleted bentonite, palleted calcium carbonate, and covered storage for polymers).

- Additional location space shall be provided beside the rcadway for a DuPont representative's traller. This traller location should be about halfway between the AMH No.1 and AMH No. 2 locations. Adequate off roadway parking should be provided at the trailer to prevent parking at the wellsite. Parking surface should be roadway material.

2. Move In and rig up rotary $\mathrm{rig}$ as specified in the $\mathrm{Rig}$ Specifications (pg. 24).

3. Drill 16 inch hole to \pm 80 feet using the drilling mud specified in the Mud Program (pg. 14).

4. Circulate and condition hole with 25 bbls. of viscous pill specified in Mud Program followed by 80 bbls ( 2 hole volumes) of mud usitid for drilling.

5. Run Compulog I (GR-SPRES-16"SN-64"LN-CAL).

6. Plug back with a fine sand (such as $40 / 60$ or blast sand) to 39 feet above depth of desired lateral specified by geologist. (Probable lateral depth is $75 \mathrm{ft}$. Frobable plug back point is 36 $\mathrm{ft}$. Hole volume is $1.397 \mathrm{cu} \mathrm{ft} / \mathrm{ft}$ ) 
7. Run $36 \mathrm{f}^{\prime}$. whipstock joint of 8-5/8" (8" nominal) Sch. 40 line pipe for casing to a TVD of 36 feet as specified in Casing Running And Cementing Procedure (pg. 17). Dimensions for the whipstock joint are given in Figure No. 7. Orient whipstock and casing to $57.87^{\circ}$ ( ref TN) while running pipe. NOTE: whipstock orientation will vary depending on final surface locations. Set c.sising on bottom and hang off on rig floor.

8. Grout casing in place as specified in Casing Running And Cementing Procedure (pg. 17).

9. Allow grout to set 8 hours (minimum allowable compressive strength 500 psi) before drillout.

10. Rig up centrifugal pump, flowline cleaner with $120^{\prime}$ s or 8 cone mud cleaner with $120^{\prime} \mathrm{s}$ over $175^{\prime} \mathrm{s}$, and 4 section metal mud pit as shown on Figure No. 8. Have a selection of screens from 120 to 220 mesh available on location with replacements.

11. Install 8-5/8" tee head and mud return line to dirt pit.

12. Run in hole with $7-3 / 4 "$ bit and casing scraper on drill rod and drill out to top of whipstock ( $\pm 25 \mathrm{ft}$.) by passing steel pits for circulation.

13. Lay down drill rods and tubing. Pick up 3-1/2" EUE drill pipe with API 3-1/2" IF joints modified for dri11 rod tongs and carouse1. Rig up tongs and slips for Eastman Christensen equipent. For convenience, the modified $3-1 / 2$ " may be run pin up but EC oquipment must be run pin down. (3-1/2 IF pin $\times 3-1 / 2$ " IF pin sub required at top of EC equipment.)

14. Rig up Eastman Christensen.

15. Drill out whipstock and pilot hole using 6-1/2" short shank tricone bit (API 111) with an open throat, 1 joint wiggly drill 
collar, and modified 3-1/2" drill pipe. Clean off whipstock and dril1 2 to 3 feet of open hole. Wipe out window if necessary.

16. Drill angle build section using 6-1/2" short shank tricone bit (API 111) with an open throat, curved drill guide, and modified 3-1/2" drill pipe.

17. Surveys in the angle building section of the hole will bo performed after drilling 15 feet, 30 feet, 45 feet, and 60 feet. Rig up slink line unit and pump down single point surveys at the specified depths. Use a 15 foot pup joint to keep the pumping head at the drill floor. Since high ROP's are expected, double chain slick line sheave to derrick and leave sheave, slickline, pump down head and packoff, and upper portion of survey tool in derrick at all times.

18. If difficulty in obtaining adequate angle is experienced, ferform the following.

a. Kun in hole with open ended drill pipe.

b. Plug back hole 11 feet with 2 sacks Cal-seal.

c. Allow Cal-seal to set 1 hour.

d. Re-dri11 hole.

e. Survey new hole position.

Immediately upon completion of the survey, plan and section views and tabular format will be posted by Eastman Christensen in the Du Pont representative's trailer.

NOTE: $\Delta 11$ directional surveys will be reported in degrees and decinals. All azimuth readings will be recorded in degrees clockwise from True North. (Quadrant reference is not acceptable.) Well position coordinates will be recorded in the local SRP Grid Coordinate System and noted as such.

19. Dri11 350 foot lateral using 6-1/4" tricone bit (API 111) with an open throat, 6" diameter nearbit stabilizer, 5.72" diameter steering stabilizer, 420 feet of wiggly drill collars, and 30 
feet modified 3-1/2" drillpipe. This assembly has an aggresive build rate $\left(40^{\circ} / 100 \mathrm{ft}\right)$ to compensate for anticipated washout. Take directional surveys using the pump down single shot on slickline every 60 feet of drilled lateral.

20. After drilling to TD, circulate and condition hole using the following procedure:

a. Pump drilling mud at 140 to 230 GPM for 2 to 3 hole volumes.

b. Pump 10 bb1 viscous sweep (add suction line volumes) as specified in the Mud Program. Attempt to maintain a circulation rate of 100 to $140 \mathrm{GPM}$.

c. Pump 2 additional hole volumes of drilling mud maintaining 140 to 230 GPM rate.

d. Spot viscous pill on bottom.

21. POOH and rig up for gyro survey. Run Eastman Christensen gyro survey too $i$ on 420 feet of wiggly drill collars, and 30 feet of modified 3-1/2" drill pipe. Obtain one station every $30 \mathrm{ft}$ in the lateral and uild sections. No stations are necessary in the vertical sectluk. $\mathrm{NOH}$.

22. After drilling and surveying 350 feet of lateral, go in hole with 7-3/4" hole opener (Drillex 6-7/8" Simplex bit), wiggly drill collars, and dr111 pipe. Open hole from 6-1/4" to 7-3/4" diameter over the open hole interval (36 ft to $449 \mathrm{ft}$ ). Limit rate of penetration to $6 \mathrm{ft} / \mathrm{min}(5 \mathrm{~min} / 30 \mathrm{ft}$ joint) with a circulation rate of 225 to 250 GPM.

23. After hole opening, circulate and condition hole as in 22 above but Increase the circulation rates in steps (a) and (c) to 300 GPM to prepare well for completion.

24. Rig down Eastman Christensen. Lay down modified 3-1/2" drill pipe. 
25. Pul1 8-5/8" tee head. Weld on threaded nipple and install casing head as per Figure No. 9.

26. Rig up casing elevators.

27. Run in hole with stab-in float shoe, 295 feet of 5-1/2" (nominal) wire wrapped screen, $30 \mathrm{ft}$. of casing, port collar, external casing packer, and 99 feet of 5-1/2", 14 lbs./ft. plain end casing as specified in the Casing Running and Cementing Procedure (pg. 19). Strap on 2 strings of 3/4" IJ PVC tremmie pipe and 1 string of $3 / 8$ " 304 SS control tubing. Attach ECP fitting and inline check to bottom of $3 / 8$ " tubing and fill tubing with water. Tie 3/8" tubing to inflation port on ECP through check valve. Hang tremmie pipe $10 \mathrm{ft}$ above ECP. Band on lines with 2 bands per joint orienting all strings to the top of the hole. Elevator doors must be oriented to allow feed through of external strings. DO NOT set casing on bottom. Cut and hang off casing in casing head. If pipe becomes stuck, use the following procedure.

a. Hang off casing on rig floor. Rig up 2-3/8" tubing tongs, elevators, and concentric slips.

b. RIH with stab-in joint and 2-3/8" $4.7 \mathrm{lbs} / \mathrm{ft}, 8 \mathrm{rd}$, EUE tubing to surface. Space out on last joint to put tubing joint about 1 foot above casing or screen joint.

c. Stab into float shoe.

d. Rig up circulating head to tubing. Circulate drilling mud at 220 to 250 GPM taking returns on the 5-1/2" $\times 8-5 / 8$ " casing annulus. Wash joint down to floor. Hang off casing on rig floor. Hang off tubing with concentric slips.

e. Pick up next joint of tubing on elevators and carry to near crown.

f. Pick up next joint of casing or screen using air line. Push out bottom of tubing joint so that casing can be slid up over tubing while being picked up.

8. Make up tubing joint.

h. Make up casing or screen joint.

1. Wash down joint as in (d) above. 
j. Repeat steps (e) to (i) until pipe is run to TD.

NOTE: If screen is still being run in hole, tubing will have to be in 20 foot sections to match sceen lengths (ie a $20 \mathrm{ft} j \mathrm{ft}$ ).

28. Lay down casing elevators.

29. Inflate external casing packer by pumping water down $3 / 8^{\prime \prime}$ line at $1 / 4$ GPM until reaching 500 psi. DO NOT EXCEED 1000 PSI. Shut-in $3 / 8$ " needle valve. Install pressure gage and needle above the needle valve so that the ECP element pressure can be observed and recorded.

30. Grout 5-1/2" casing in place using procedure given in Casing Running and Cementing Procedure (pg. 22). Shut well in 8 hours to wait on cement. (Minimum compressive strength $=500 \mathrm{psi}$ )

31. Empty and flush steel mud tanks until clean. Drain and flush all lines, headers, valves, and pumps. Fill steel pits with clean, fresh water.

32. Pick up tubing tongs, elevators, and slips. Pick up 2-3/8, $4.7 \mathrm{lbs} / \mathrm{ft}, 8 \mathrm{RD}, \mathrm{EUE}$ tubing.

33. Run in hole with stab-in joint (see Figure No. 10), and 414 feet of tubing. Run centralizers and opposed cup packers every 60 feet for the first 300 foot of tubing. Pick up casing pack off on last joint. Set casing pack off and stab into float shoe.

34. Displace mud, remove mud cake, and initiate well development by reverse circulation of freshwater past liner at 300 GPM.

Circulate down the casing-casing annulus and take returns on the 2-3/8" tubing. Slower initial rate may be necessary to displace viscous mud pill. Circulate until pressure exceeds 46 ps 1 plus friction or all fluid returns are clear. If fluid returns are clear slowly increase rate to $400 \mathrm{GPM}$. Circulate until pressure 
exceeds 100 psi at 300 GPM or 140 psi at 400 GPM or all fluid returns are clear. Slowly shut down pumps.

35. Pull out of hole with tubing and stab-in joint.

36. Go in hole with jetting sub and 2-3/8" tubing. Pick up casing packoff on last joint. Pack off casing and run jetting sub to TD.

37. Rig up power swivel and water truck. Cross stake and chain all pressure lines. If necessary, change out pump liners to obtain rate and pressure. Pressure test all pressure lines to 1500 psi.

38. Jet screen clean and finish well development using freshwater filtered to 5 microns (use cartridge filter pack). Jet at 20 to $30 \mathrm{GPM}$ and 1,200 psi. Take returns on the tubing-casing annulus. Begin jetting from the bottom up at 3 to 4 feet per minute with rotation. Continue jetting until reaching the top of the screen at $147 \mathrm{ft}$.

39. Go back to TD (444 ft) at 5 to 10 feet per minute while continuing to jet and rotate.

40. Pull out of hole with $2-3 / 8^{\prime \prime}$ tubing and jetting tool. Lay down tubing elevators and slips.

41. Go in hole with port shifting tool on 2-3/8" tubing. Close casing port collar at $115 \mathrm{ft}$. Pull out of hole with tubing and shifting tool.

42. Go in hole with bull plug, $2 \mathrm{ft}$ pup jt with centralizer and orifice, $1 \mathrm{jt}$ fiberglass tbg, $2 \mathrm{ft}$ jt with centralizer, opposed cup packer, $1 \mathrm{jt}$ fiberglass tbg, $2 \mathrm{ft}$ sub with centralizer and orifice, $1 \mathrm{jt}$ fiberglass tbg, $2 \mathrm{ft} j \mathrm{jt}$ with centralizer, opposed cup packer, $1 \mathrm{jt}$ fiberglass tbg, $2 \mathrm{ft}$ pup $\mathrm{jt}$ with centralizer and orifice, 1 jt fiberglass tbg, $2 \mathrm{ft} j \mathrm{jt}$ with centralizer, opposed 
cup packer, $1 \mathrm{jt}$ fiberglass tbg, 2 ft sub with centralizer and orifice, $1 \mathrm{jt}$ fiberglass tbg, $2 \mathrm{ft} \mathrm{jt}$ with centralizer, opposed cup packer, $1 \mathrm{ft}$ fiberglass tbg, $2 \mathrm{ft}$ sub with centralizer and orifice, 1 jt fiberglass tbg, 2 ft jt with centralizer, opposed cup packer, and fiberglass tubing to surface. Hang off tubing with bull plug at least $5 \mathrm{ft}$ off bottom and not more than $15 \mathrm{ft}$ off bottom. Monitor and record slackoff weight at each joint going in hole. Figure No. 11 gives the dimensions of the cetralizer sub. Figure No. 12 gives the dimensions of the centralizer and orifice sub. Figure No. 13 is a schematic of the completion system to be installed in the well.

NOTE: use only strap wrenches for making up and breaking out fiberglass joints.

43. Turn well over to plant personnel for injection piping. 


\section{MUD PROGRAM}

The proposed drilling fluid for the DuPont AMH No. 1 is a bentonite polymer freshwater system for both the vertical section and the horizontal section. In the vertical section, mud properties will be as conventionally used in area water wells and monitoring wells. Permission has been granted by DHEC for the use of EZ MUD (a PHPA or partially hydrolyzed polyacrylamide) and QUIR TROL (an organic polymer). If necessary, the PHPA may be used to formulate high viscosity sweeps to assist in hole cleaning and borehole stabilization in the 16 inch vertical hole.

In the horizontal section, the basic drilling mud will consist of 10 lbs/bbl (23.8 lbs/100 gals) bentonite, 87.3 lbs/bbl (208 lbs/100 gals) sized calcium carbonate, and freshwater. The calcium carbonate is needed to provide a weight of $9.5 \mathrm{ppg}$ to keep the horizontal wellbore open. The calcium carbonate will also provide a bridging material to reduce fluid loss. QUIR TROL will be added to the base system for suspension of weight material and to provide a tough pliable mud cake to resist erosion by turbulent flow. Turbulent flow will be used throughout drilling to ensure the horizontal section is clear of cuttings. The horizontal section will be cleaned out using turbulent flow prior to pulling drill pipe out of the horizontal section. A high viscosity pill will be left on bottom. It is imperative that this pill have a $9.5 \mathrm{ppg}$ mud weight, excellent fluid loss control, and a moderate to high viscosity.

Solids control equipment for the vertical section of the hole will consist of a double section dirt pit as normally used in area wells. Prior to drilling the horizontal section, additional oilfield solids control equipment will be rigged up in conjunction with the dirt pits. The solids control equipment will be used to remove the drill solids which tend to absorb the polymers without yielding appropriate mud properties. This equipment will consist of a Derrick Flo-Line Cleaner or an 8 cone hydrocyclone manifold discharging into the mixing section 
of a 4 compartment steel pit. All three sections will have continuous agitation. The pit will be manifolded to provide a mixing section, a slug pit, and a suction pit. A schematic of the mud equipment and solids control equipment is shown in Figure No. 8. A 100 bbl drill water tank will be kept full at all times in the event of whole mud losses.

Avoid excessive penetration rates in both the vertical and horizontal sections of the hole. The maximum allowable penetration rate for the vertical section will be calculated on site based on the mud pump capacities. The maximum penetration rate for the horizontal section will be $6 \mathrm{ft} / \mathrm{min}$ at a circulation rate of 140 to $180 \mathrm{GPM}$.

The mud company will provide a full mud kit with 6 speed rheometer at location. This equipment will be used to ensure that optimuin mud properties are maintained during drilling and completion of the horizontal section. 
MUD PROGRAM

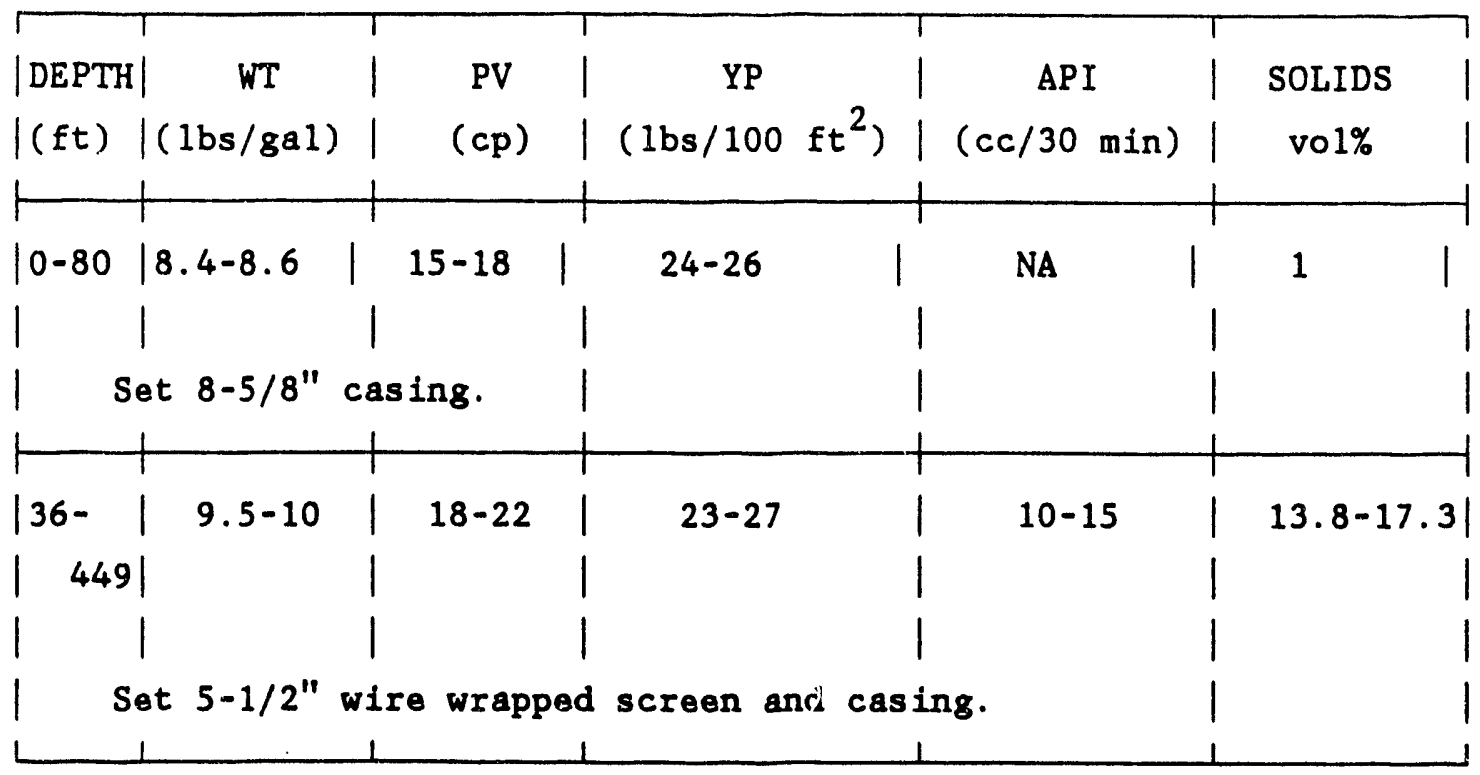

MUD FORMULATION

0 - 80 FT (VERTICAL SECTION)

20-25 ppb bentonite (Aquage1)

$36-449$ FT

8-10 ppb bentonite (Aquage1)

0.25 ppb Quik Trol

87 ppb calcium carbonate (Baracarb 5,50,150,600)

\section{SWEEP FORMULATION}

0 - 80 FT (VERTICAL SECTION)

1 qt. PHPA polymer (EZ Mud) down drillpipe at connection NOTE: Drill pipe pressure may decrease during pumping of the sweep due to friction reduction properties of the polymers.

\section{HIGH VISCOSITY PILL FORMULATION}

36 - 449 FT

8-10 ppb bentonite

0.5 ppb Quik Trol

87 ppb calcium carbonate (Baracarb $5,50,150,600$ ) 


\section{CASING RUNNING AND CEMENTING PROCEDURE}

\section{8-5/8" Casing}

A. Dri11 to 80 feet with 16" bit. C\&C and POOH. Record circulating time before $\mathrm{POOH}$ and time at start off bottom.

B. RU electric line. Log hole. POOH and rig down electric line.

C. GIH w/ open ended drill rods. Break circulation. Plug back with sand to $39 \mathrm{ft}$ above lateral depth specified by geologist. (Assumes that the bottom of the window is $1 \mathrm{ft}$ above the bottom of the joint. Use actual measurement to adjust.) POOH.

D. RU casing lift equipment, slips, and welding equipment.

NOTE: Be sure all 8-5/8" casing has been inspected, drifted $\left(7-3 / 4^{\prime \prime} \times 6 "\right)$, tallied, and steam cleaned. Weld on casing stops (as shown in Figure No. 14) prior to ruming in the hole.

\section{CASING PROGRAM}

$\begin{array}{lllll}\text { DEPTH } & \text { SIZE } & \text { WEIGHT } & \text { SCH } & \text { ID } \\ 0-36^{\prime} & 8-5 / 8^{\prime \prime} & 28.55 & 40 & 7.981^{\prime \prime}\end{array}$

CENTRALIZERS: 2 big hole centralizers per jt with welded stop collars

E. Run whipstock joint to TD ( $-36 \mathrm{ft}$.$) . Orient whipstock to$ $57.87^{\circ}$ (ref TN) while running pipe. Tag bottom and pick up casing weight $( \pm 1000 \mathrm{lbs})$. Hang off casing on rig floor. Record time when casing hung off. 
F. GIH w/ muleshoe, 2-3/8", $4.7 \mathrm{lbs} / \mathrm{ft}, 8 \mathrm{rd}$, EUE tremmie pipe to TD (36 ft.).

G. Grout casing in place by continuous pumping down tremmie pipe. Pump 20\% excess to displace contaminated cement from annulus. Record time at beginning and end of pumping cement.

Slurry: $\quad$ Class A $+2 \% \mathrm{CaCl}_{2}$

Volume: $\quad 48 \mathrm{cu} \mathrm{ft}+20 \%$ excess $=58 \mathrm{cu} \mathrm{ft}(49 \mathrm{sx})$

Density: $15.6 \mathrm{ppg}$

Yield: $\quad 1.18 \mathrm{cu} \mathrm{ft} / \mathrm{sk}$

Water: $\quad 5.2 \mathrm{gals} / \mathrm{sk}$

NOTE: $1 \mathrm{sk}=94 \mathrm{lbs}$

Cement samples will be collected and saved during the job. These may be used to determine adequate WOC time.

H. Pull tremmie pipe. (NOTE: expected thickening time of cement is $1: 30$ )

I. If necessary, perform top job using the same cement design. The DuPont representative will provide the volumes necessary to preform the top job.

J. Allow grout to set a minimum of 8 hours prior to drilling out. The minimum allowable compressive strength is 500 psi. 


\section{2. $5-1 / 2^{\prime \prime}$ Casing - Running Casing}

A. Drill curve and lateral section $w / 6-1 / 4^{\prime \prime}$ bit to a measured depth of $449 \mathrm{ft}$. C\&C and POOH. GIH \& survey hole. POOH.

B. GIH w/ 7-3/4" hole opener (Drillex 6-7/8" Simplex bit), wiggly drill collars, and drill pipe. Open hole from 6-1/2" to 7-3/4" diameter over the open hole interval(36 ft to $449 \mathrm{ft}$ ). Limit rate of penetration to $6 \mathrm{ft} / \mathrm{min}$ ( 5 minutes per $30 \mathrm{ft}$ joint) to allow filter cake to redevelop. Slower penetration rates may be necessary. Circulate at 225 to 250 GPM (2.3 fps $\leq A V \leq 2.6$ fps) while opening the hole.

C. Circulate and condition the hole as follows.

1. Pump drilling mud at. $300 \mathrm{GPM}$ ( $\mathrm{AV}=3 \mathrm{fps})$ for 40 to 60 bbls ( $1700 \mathrm{gals}$ to $2500 \mathrm{gals}$ ).

2. Pump $10 \mathrm{bbl}$ viscous sweep (add suction line volumes to sweep volume). Attempt to maintain a high circulation rate. Limit surface pressures to 900 psi.

3. Pump 40 bbls of drilling mud at $300 \mathrm{GPM}$.

4. Spot viscous pill on bottom ( 25 bbls or $1100 \mathrm{gals}$ )

D. POOH and rig down Eastman Christensen, tongs, bails, and elevators.

E. Rig up bails and elevators for 5-1/2" casing. Have two sets of elevators on the rig floor. Replace bottom bail keeper bolt (both sides) with equivalent diameter and strength cotter pin and keeper on both sets of elevators. 
CASING PROGRAM

$\begin{array}{ccccccr}\text { DEPTH } & \text { SIZE } & \text { WEIGHT } & \text { GRADE } & \text { ID } & \text { DRIFT } & \text { TYPE } \\ 0-147^{\prime} & 5-1 / 2^{\prime \prime} & 14 & \text { H-40 } & 5.012^{\prime \prime} & 4.887^{\prime \prime} & \text { CSG } \\ 147^{\prime}-44^{\prime} & 5-1 / 2^{\prime \prime} & 16.8 & 304 S S & 4.94^{\prime \prime} & \ldots-- & \text { SCREEN }\end{array}$

All casing, screen, and associated equipment will be plain end with a $45^{\circ}$ bevel for welding. All joints will be less than 25 feet in length (rig limit is 25 feet). Welding procedures will be according to SRP procedure by plant approved "ris.

NOTE: Be sure all 5-1/2" screen has been inspected, gapped $\left(0.010^{\prime \prime}\right)$, drifted $\left(4.94 \times 6^{\prime \prime}\right)$, and steam cleaned.

NOTE: Be sure all 5-1/2" casing has been inspected, drifted (4.887" $\times 6^{\prime \prime)}$, tallied, and steam cleaned. Weld on casing centralizer stops (as shown in Figure No. 14) prior to running in the hole. Note that bottom 2 joints of casing will not have any centralizers.

F. Weld float shoe to first joint of screen on laydown. Pick up screen using elevators and tail rope. DO NOT ALLOW SCREENS TO STRIKE RIG STRUCTURE AS DAMAGE TO SCREEN GAPPING WILL RESULT.

G. Hang off screen on rig floor with elevators. Release - levators from bail using cotter pins. (Equip floor hands w/ needle nose pliers). Rig up second set of elevators to bails.

H. Continue running screen using procedure above and butt welding all joints. Run 295 ft of wire wrapped rod based stainless steel screen. NOTE: Screen will set down on whipstock at $25 \mathrm{ft}$. Work screen gently through angle 
building section of hole. Surface weight will decrease due to drag in open hole.

I. Weld $30 \mathrm{ft}$ of casing to top of screen. Weld port collar to top of joint and run with ports open.

J. Weld external casing packer to top of port collar. Weld on next joint of casing but do not run in hole.

K. Install bottom fitting to ECP port and inline check on $3 / 8^{\prime \prime}$ 304 stainless steel control line. Fill line with water.

L. Install $3 / 8^{\prime \prime}$ tubing with check valve in inflation port on ECP. Clamp 3/8" tubing to casing using 3 bands in the first 10 feet above the ECP. Orient the $3 / 8^{\prime \prime}$ tubing on the high side of the hole ( $57.87^{\circ}$ referenced to True North).

M. RIH 10 feet. Clamp on 2 strings of 3/4" Intergal Joint PVC 10 feet above top of ECP. Clamp bottom 5 feet of 3/4" stings to casing using 3 bands. Do not attempt to use the same bands securing the $3 / 8$ " to secure the $3 / 4$ " tubing.

N. Continue in hole with welded joints on casing. Install associated casing equipment according to the following guidelines:

(i) Install centralizers underneath the three external tubing strings.

(ii) Clamp the $3 / 8^{\prime \prime}$ string to the casing using 1 band $12^{\prime \prime}$ to 18 " above the casing joints and 1 band in the middle of the joint. Orient the tubing to the high side of the hole $\left(57.87^{\circ}\right.$ ref $\left.\mathrm{TN}\right)$.

(iii)Clamp the two strings of $3 / 4$ " tubing to the casing using 1 band $12^{\prime \prime}$ to $18^{\prime \prime}$ below the casing foines and 1 band in the middle of the joint. Keep the middle joint band 1 to 2 feet from the 3/8" tubing clamps. Orient 
the strings to the high side of the hole $\left(57.87^{\circ}\right.$ ref $\mathrm{TN}$ ).

(iv) Insure that all control lines pass through spaces in stop blocks for centralizers.

0 . Run $99 \mathrm{ft}$ of $5-1 / 2^{\prime \prime}, 14 \mathrm{lb} / \mathrm{ft}, \mathrm{H}-40$ casing from the top of the ECP to surface. DO NOT RUN FLOAT SHOE TO TD. Run casing to 5 feet off bottom. CAUTION: FILL MAY BE PRESENT.

\section{5-1/2" Casing - Grouting Casing}

A. Manifold the two strings of $3 / 4 "$ IJ PVC together at the surface and tie to mud pump for grouting.

B. Install needle valve, tee, pressure gage, needle valve, and plumbing to pump on $3 / 8^{\prime \prime} 1$ ine.

C. Inflate ECP by pumping water at $1 / 4$ GPM down the $3 / 8^{\prime \prime}$ tubing. Note and record pressures, rates, and times during the inflation of the ECP. A final pressure of $500 \mathrm{ps} 1$ on the element will be required to provide zonal isolation. DO NOT EXCEED 1000 PSI DURING INFLATION.

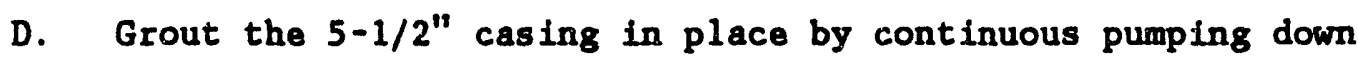
manifolded 3/4" PVC tremmie pipes. Pump 20\% excess to displace contaminated cement from annulus. Record time at beginning and end of pumping cement. 
Slurry: $\quad$ Class $\mathrm{A}+2 \% \mathrm{CaCl}_{2}$

Volume: $\quad 25 \mathrm{cu} \mathrm{ft}+20 \%$ excess $=30 \mathrm{cu} \mathrm{ft}(25 \mathrm{sx})$

Density: $\quad 15.6 \mathrm{ppg}$

Yield: $\quad 1.18 \mathrm{cu} \mathrm{ft} / \mathrm{sk}$

Water: $\quad 5.2 \mathrm{gals} / \mathrm{sk}$

NOTE: 1 sk $=94$ lbs

Cement samples will be collected and saved during the job. These may be used to determine adequate WOC time.

NOTE: expected thickening time of cement is $1: 30$

E. If necessary, perform top job using additional 3/4" IJ PVC tremmie pipe and the same cement design. The DuPont representative will provide the volumes necessary to perform the top job.

F. Allow grout to set a minimum of 8 hours prior to well development. The minimum allowable compressive strength is 500 psi. 


\section{RIG SPECIFICATIONS}

The specifications contained on this page are minimum requirements.

Hookload Capacity

Drawworks Input Horsepower

Rotary Static Load Capacity

Rotary Speed Range

Torque Capacity

(Bowen S-3.5 or larger is acceptable)

Mast may be single, double, or treble

Rig mats may be required upon rig up.
$70,000 \mathrm{lbs}$

$300 \mathrm{hp}$

27,000 lbs

30 - 100 RPM

$240 \mathrm{hp}$ 
Figure 1. Xerox of map of western South Carolina and eastern Georgia. 


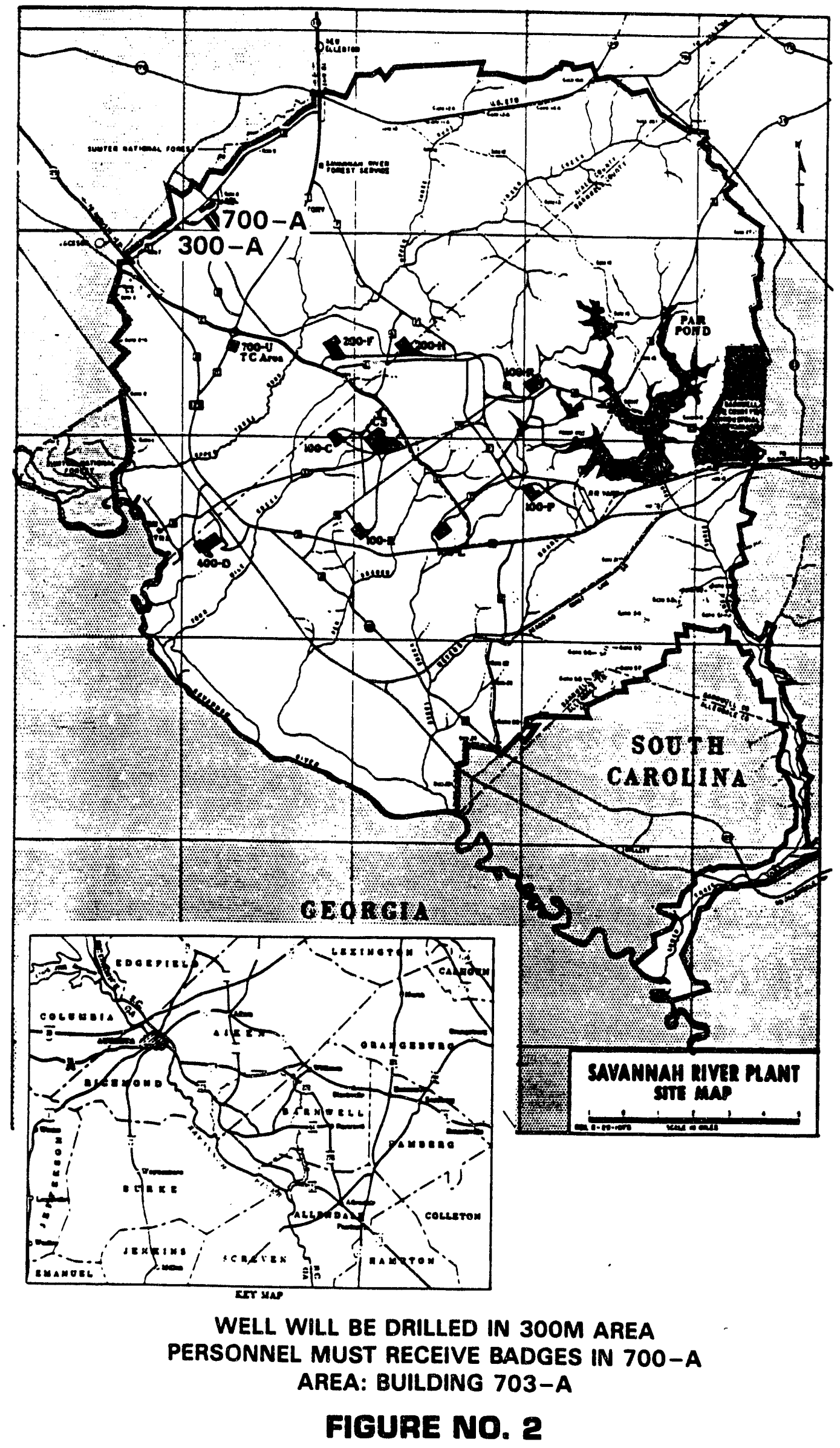


FIGURE NO. 3

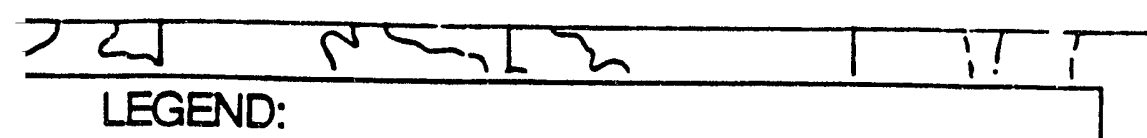

ISB = MONITORING WELL

IWM = RECOVERY WELL (PRODUCER)

/B = VADOSE ZONE WELLS (DO NOT INTEASECT WATER TABLE)

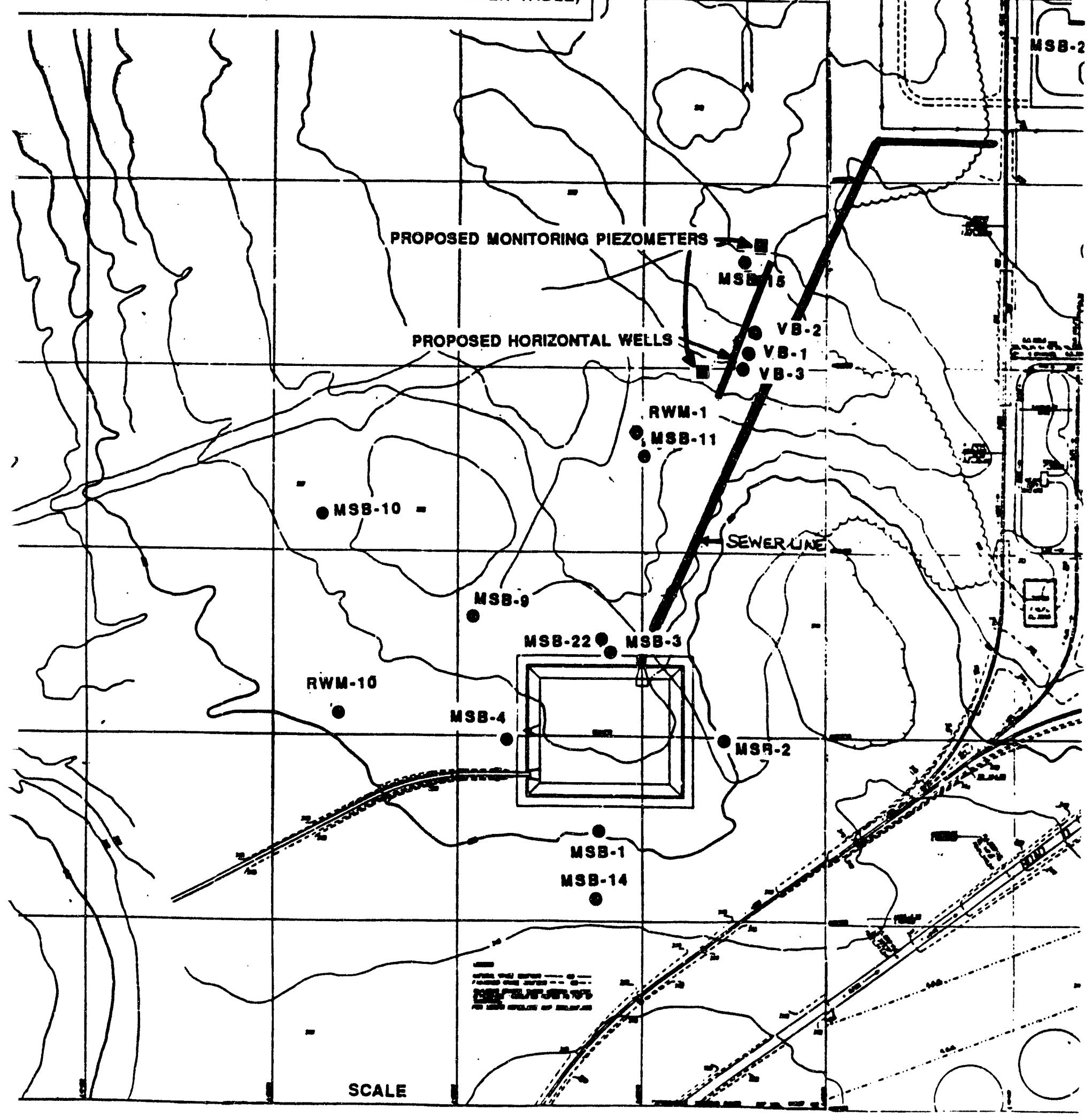


VELL: AMH NO.Z

LOCATION: NIge74!, E49765 SRP CDOR

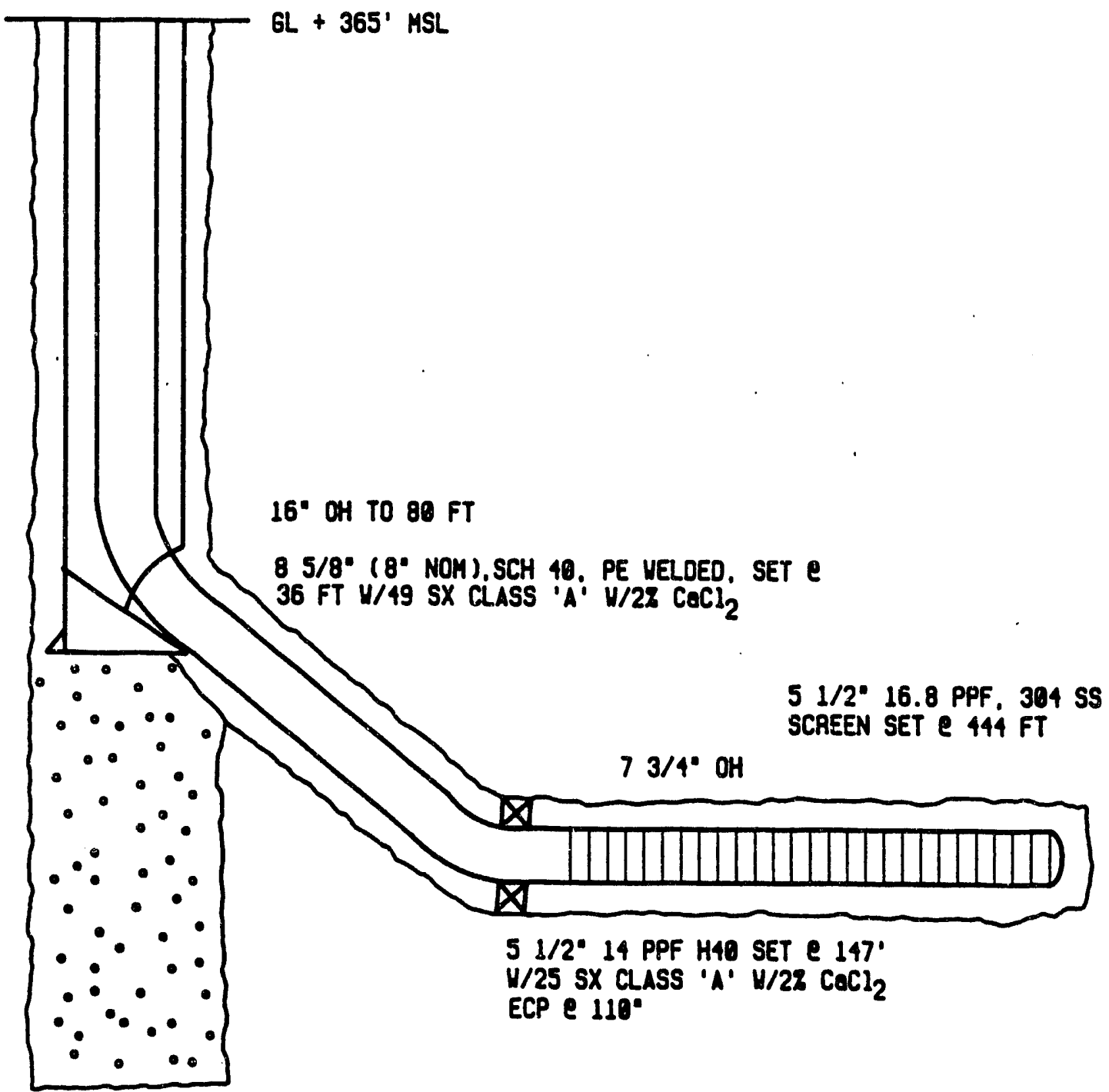

F I GURE NO. 4 


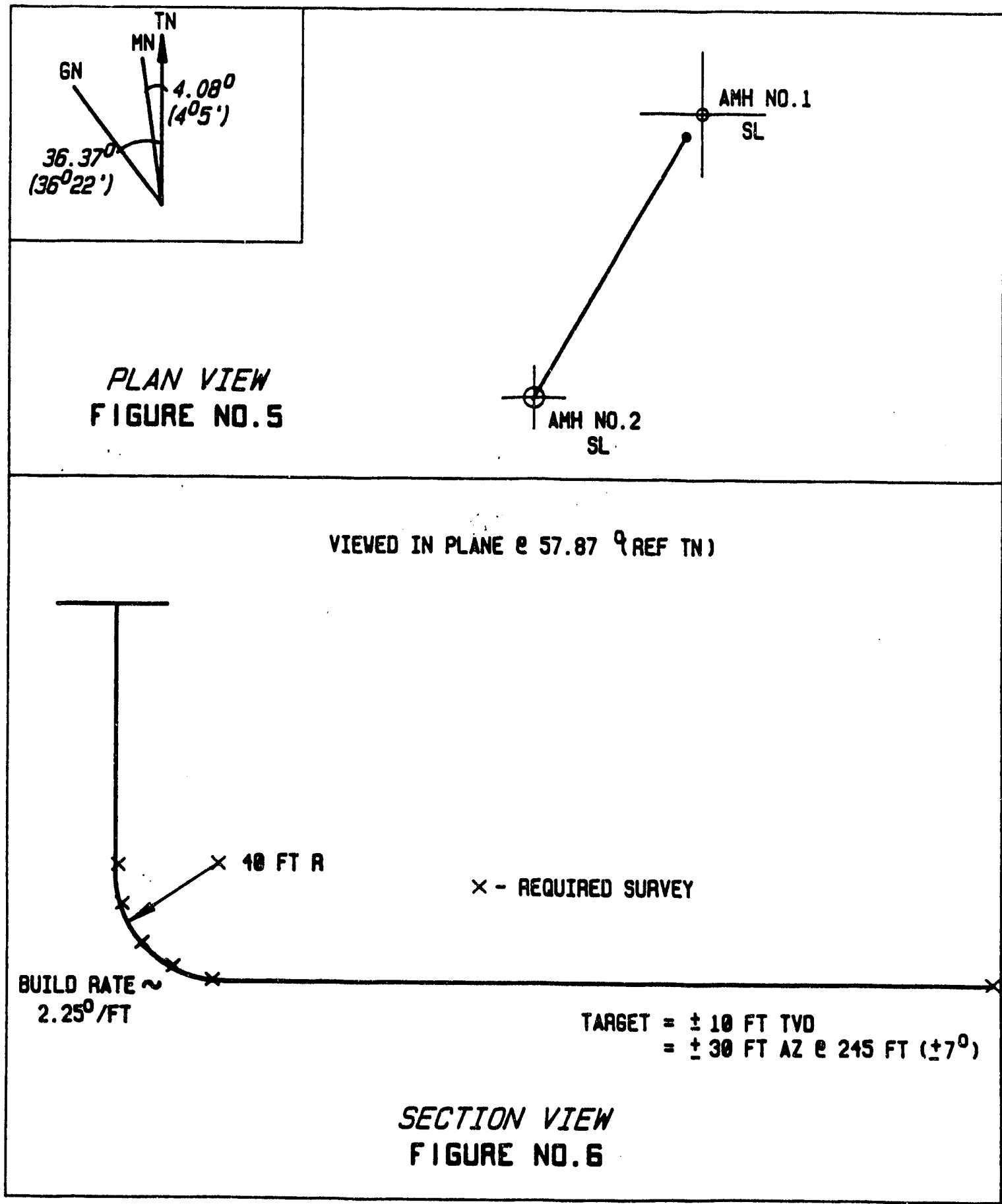




\section{DU PONT \\ CASING/WHIPSTOCK ASSEMELY}

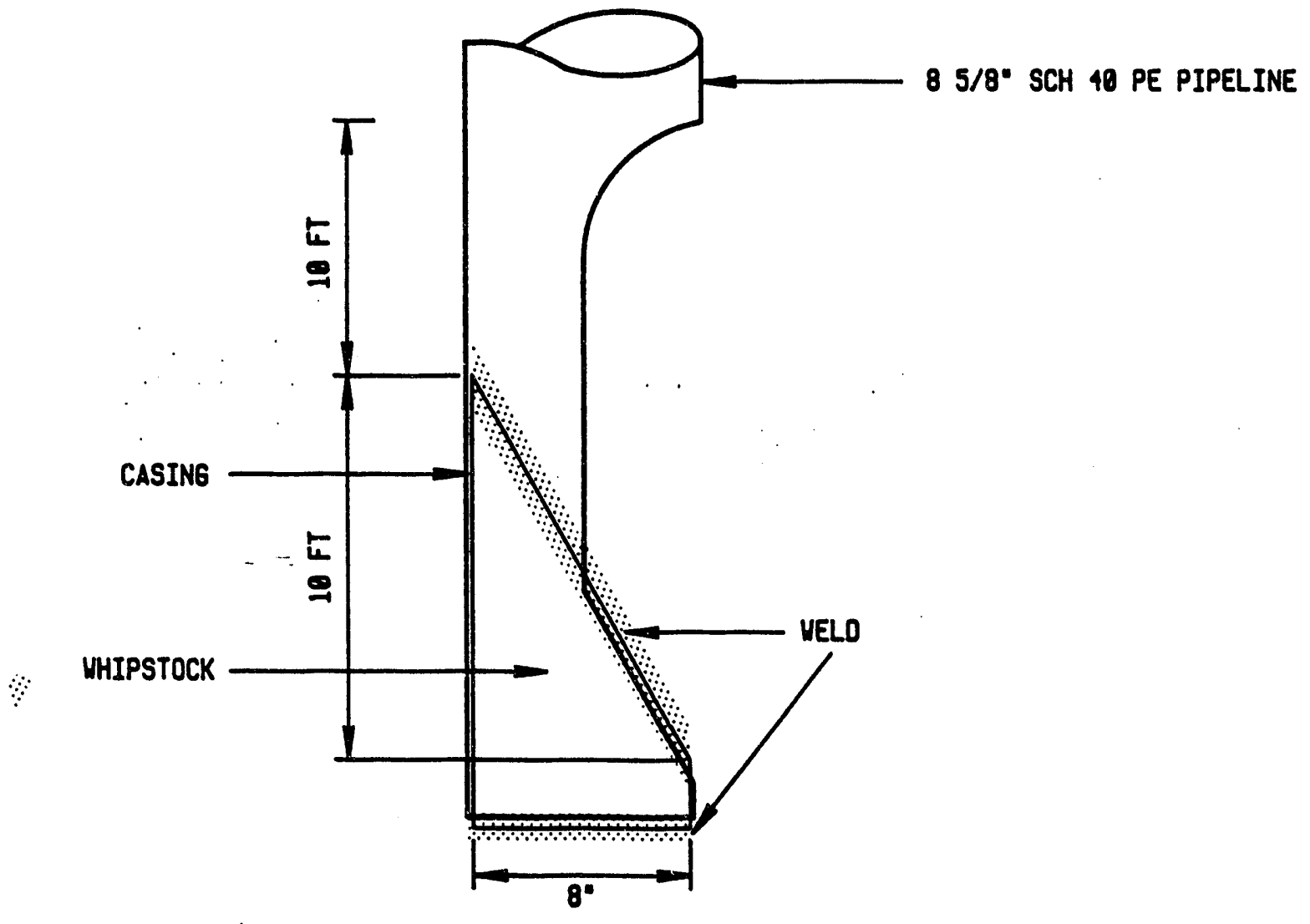

NOTE TOP OF WINDOW TO STAAT 10 FEET ABOVE

TOP OF MHIPSTOCK. OFEN WINOON $180^{\circ}$.

CENTRALIZE MHIPSTOCK IN CASING.

THEN WEZ IN PLACE.

FIGURE ND. 7 


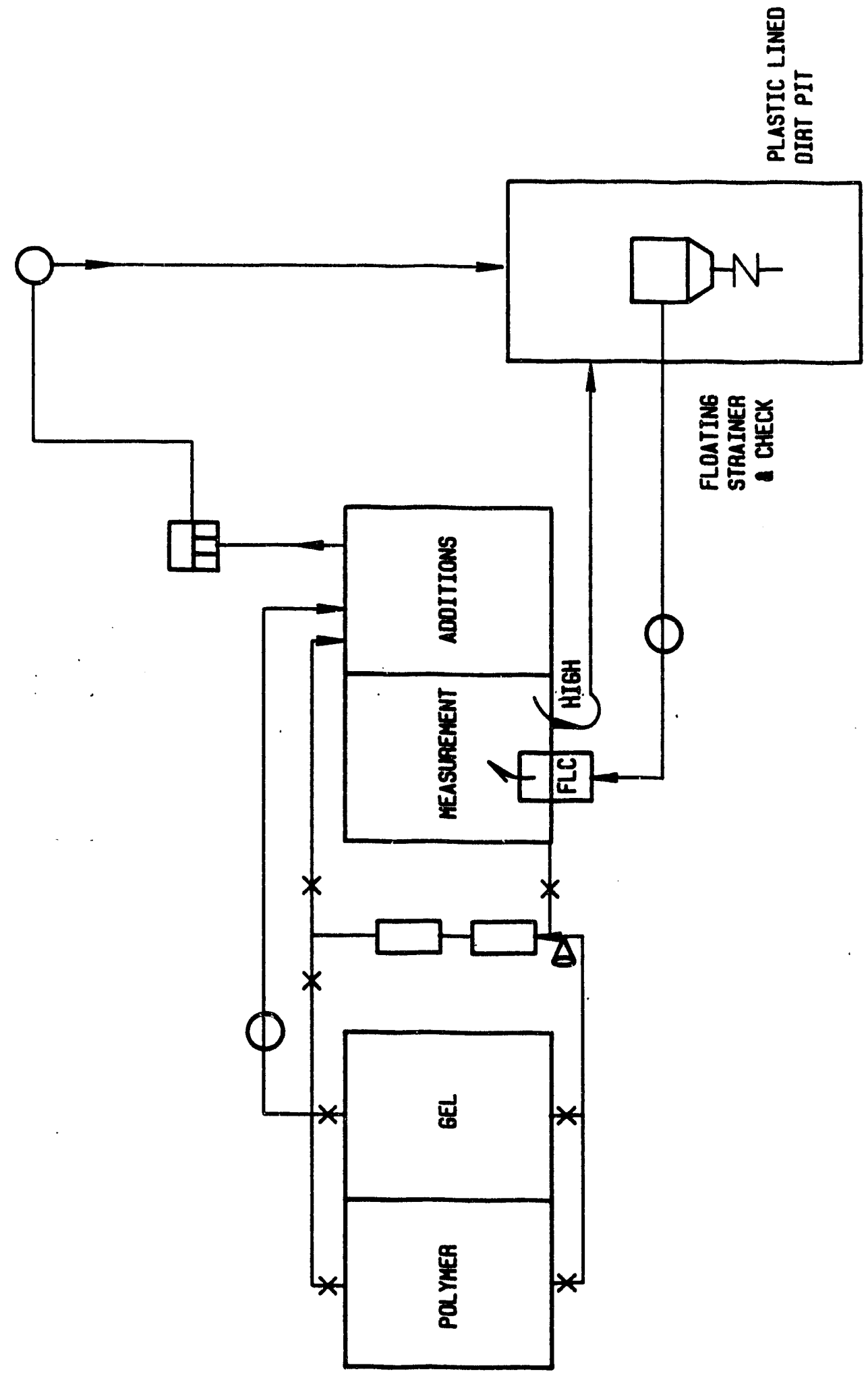

FIGURE NO.B 

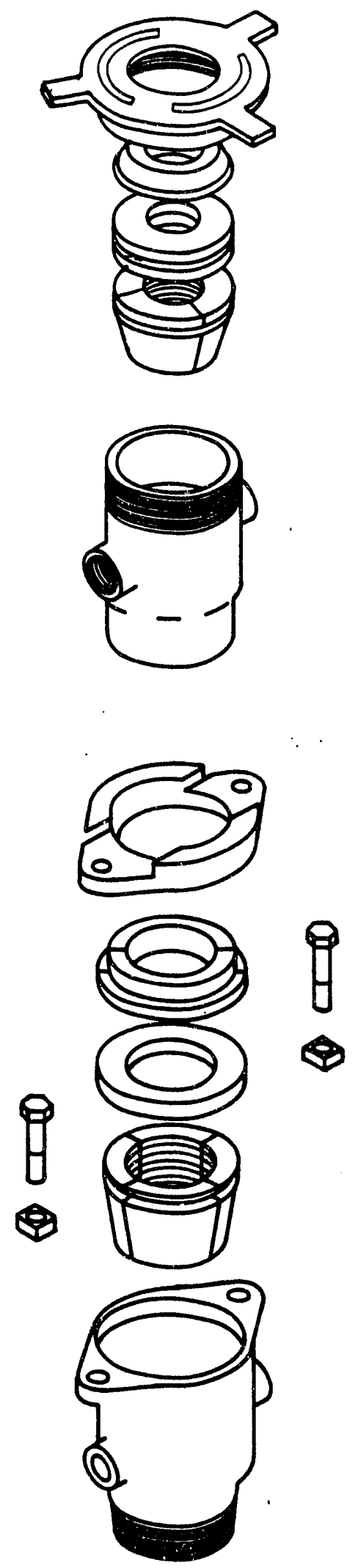

FIGURE NO. 9 


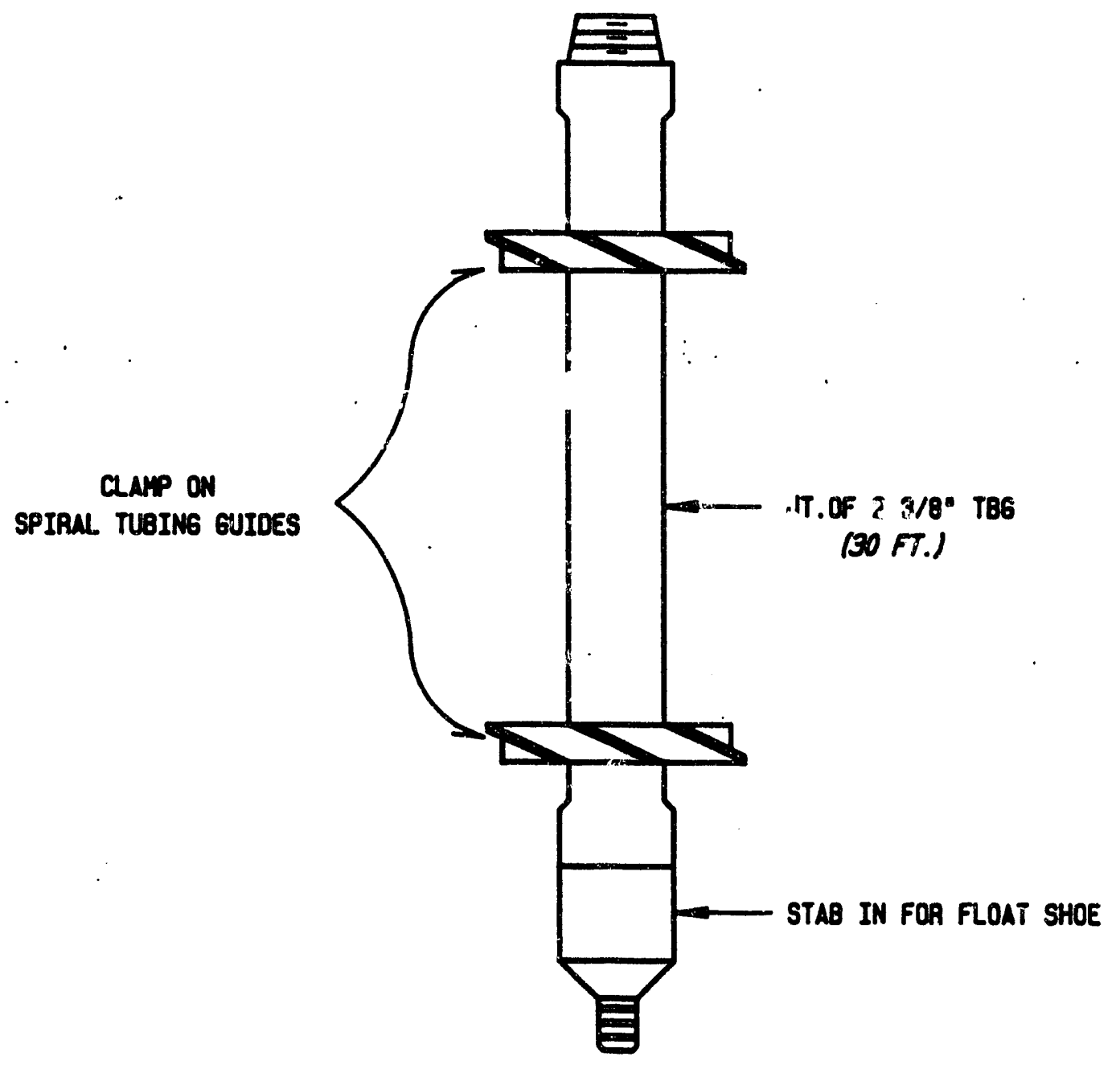

F I GURE NO.10 


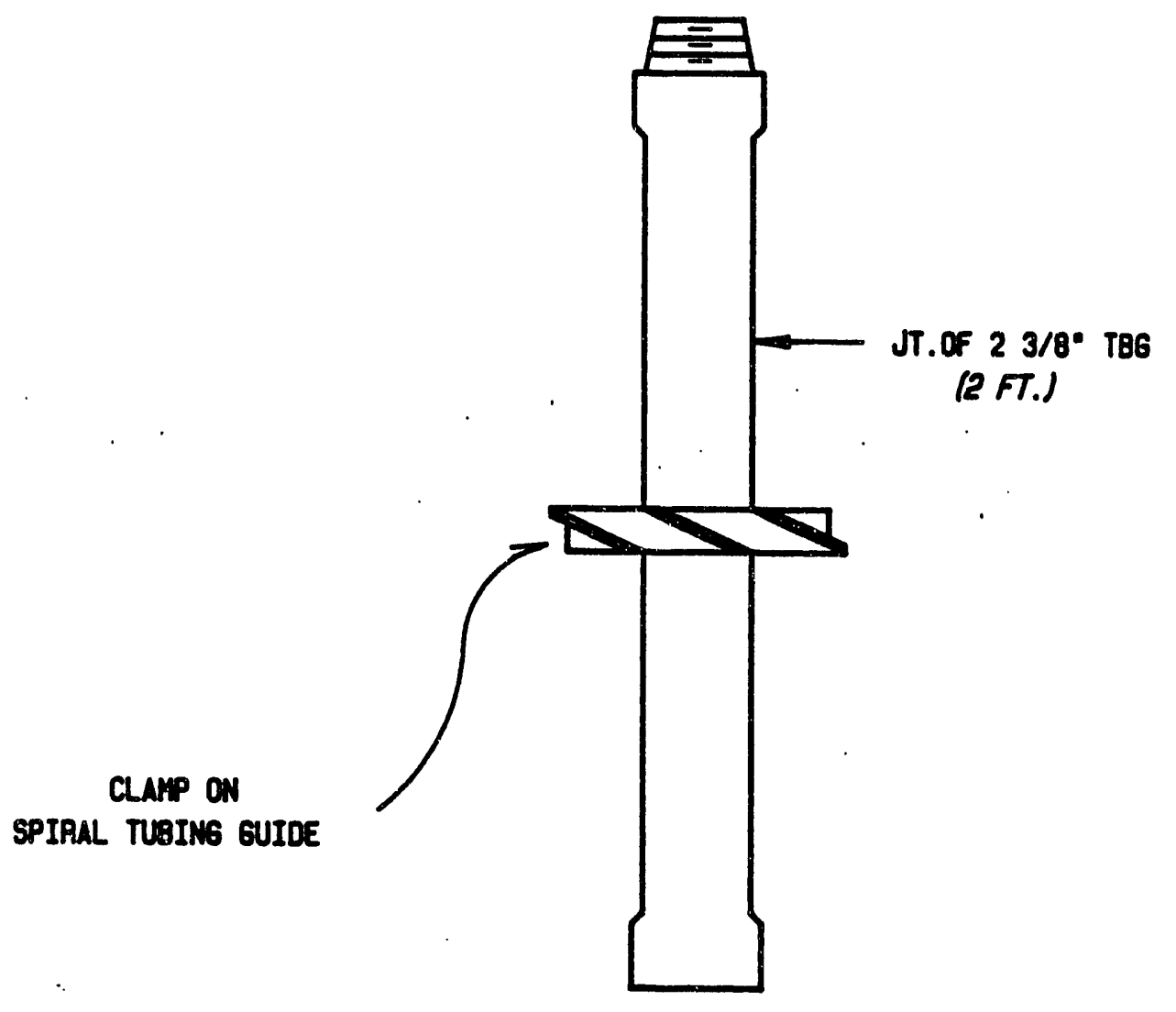

F I GURE NO. 11

CENTRAL IZER SUE 


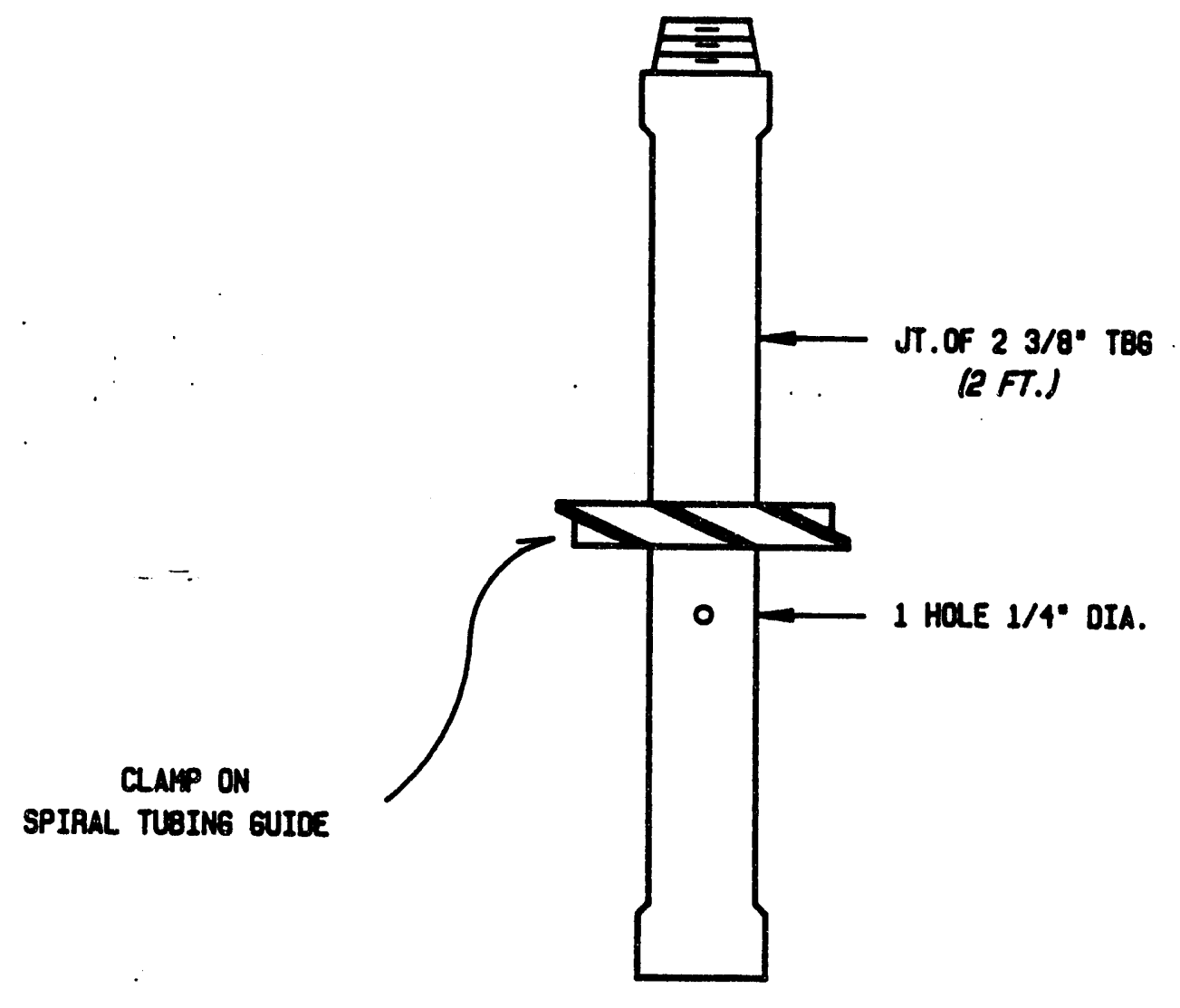

F IGURE NO.12

CENTAALIZEA AND DRIFICE SUB 


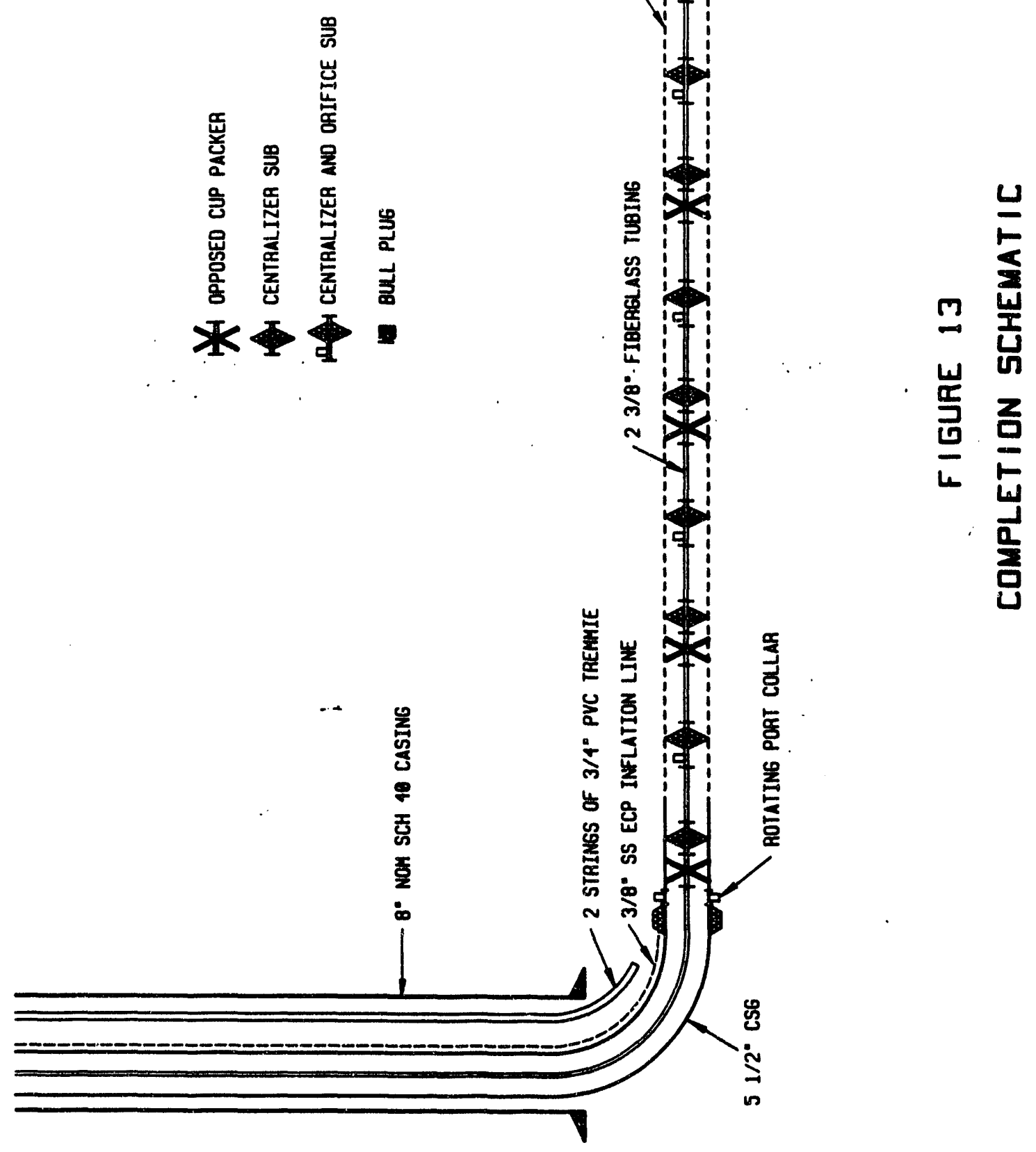




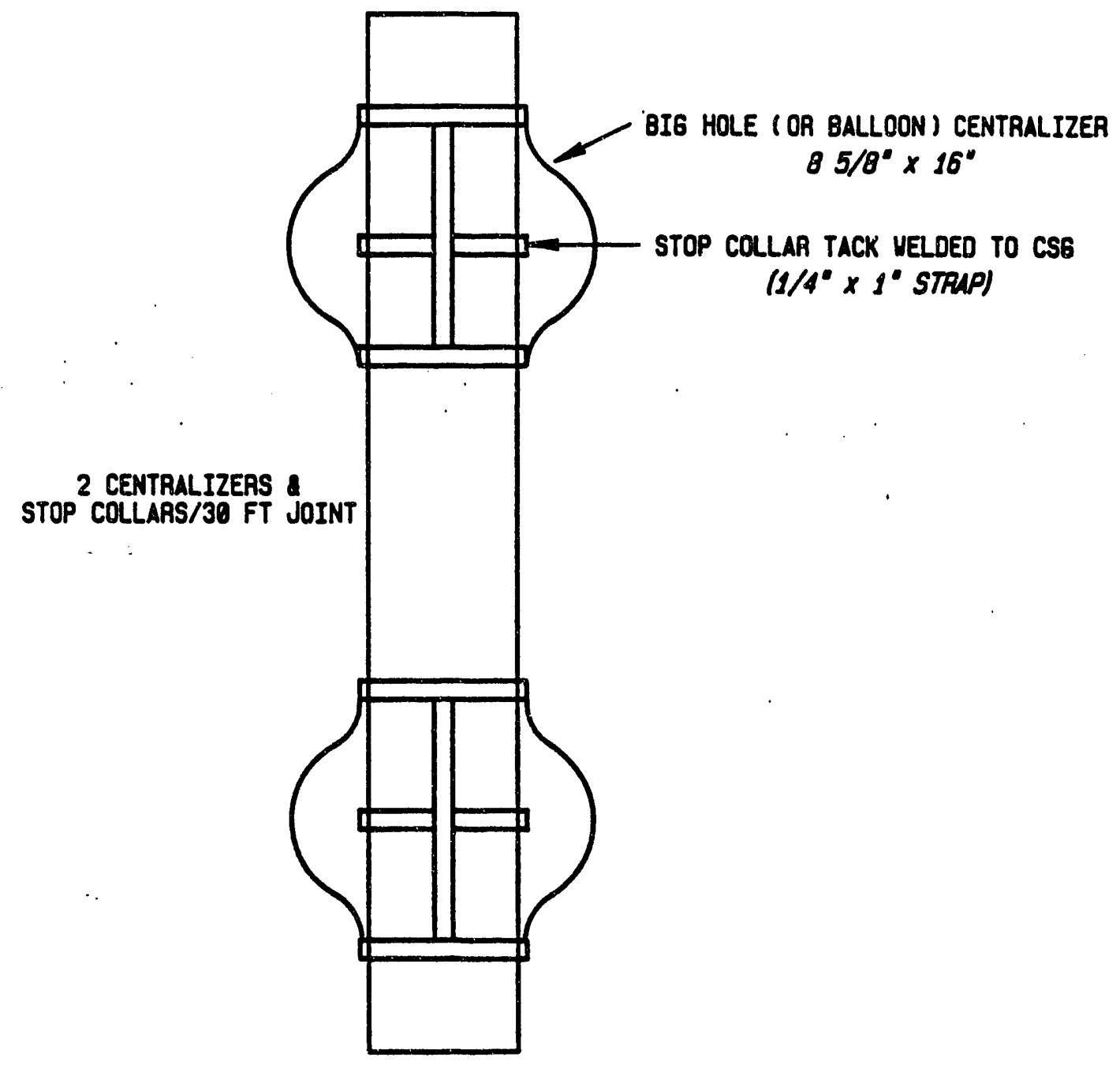

F IGURE NO.14 


\section{APPENDIX D}

\section{DIRECTIONAL DRILLING DATA}

Down-Hole Survey Data AMH-1

Down-Hole Survey Data AMH-2 


\section{CONPLETION SURVEYS}

AMH NO. 1, 2, 2B, 2C, $2 D$

AREA M

Du pont savannah River plant

AIKEN, SC

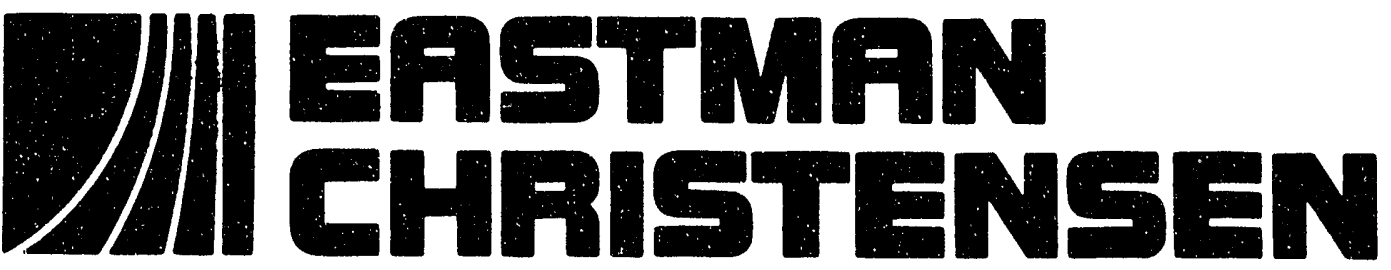


EASTMAN CHRISTENSEN COMPANY

LATERAL DRILLING

WELL OEFLECTION SURUEY

$$
\text { for }
$$

W PONT

Art - 1

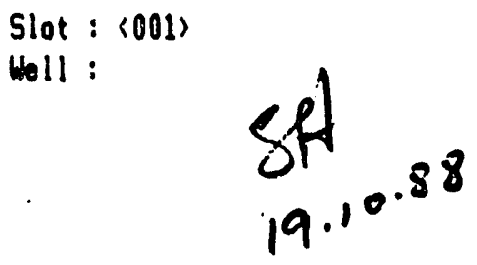

Survey Reference : S00163.40Z 


\begin{tabular}{|c|c|c|c|c|c|c|c|c|}
\hline \multirow{3}{*}{$\begin{array}{l}\text { OU PONT } \\
\text { ANH - } 1 \\
\text { Measured } \\
\text { Depth }\end{array}$} & \multirow{3}{*}{$\begin{array}{l}\text { Orift } \\
\text { Angle }\end{array}$} & \multirow[b]{3}{*}{$\begin{array}{c}\text { Orift } \\
\text { Direction }\end{array}$} & \multirow[b]{3}{*}{$\begin{array}{l}\text { Course } \\
\text { Length }\end{array}$} & \multicolumn{2}{|c|}{$\begin{array}{l}\text { Slot : (001) } \\
\text { Well: }\end{array}$} & \multicolumn{2}{|c|}{ Date Printed: } & \multirow[t]{2}{*}{$\begin{array}{l}19-0 C T-88 \\
500163.402\end{array}$} \\
\hline & & & & & 0.00 & & & \\
\hline & & & & $\begin{array}{l}\text { Vertical } \\
\text { Depth }\end{array}$ & $\begin{array}{l}\text { Vertical } \\
\text { Section }\end{array}$ & \multicolumn{2}{|c|}{$\begin{array}{l}\text { RECTANGULAR } \\
\text { COOROINATES }\end{array}$} & $\begin{array}{l}\text { Dogleg } \\
\text { Soverity }\end{array}$ \\
\hline 112.00 & 0.00 & 11.00 & 0.00 & 112.00 & 0.00 & $0.00 \mathrm{~N}$ & $0.00 \mathrm{E}$ & 0.00 \\
\hline 114.00 & 1.00 & 11.0 & $2 .($ & & & $.02 \mathrm{~N}$ & $0.00 E$ & 50.00 \\
\hline 116.00 & 0.50 & 11.00 & 2.00 & 116.00 & 0. & $0.04 \mathrm{~N}$ & $0.01 E$ & 25.00 \\
\hline 118.00 & 1.00 & 11.00 & 2.00 & 118.00 & 0.1 & $0.07 \mathrm{~N}$ & & 25.00 \\
\hline 120.00 & 3.90 & 11.00 & 2.00 & 120.00 & 0.16 & $0.14 \mathrm{~N}$ & $0.03 E$ & 100.00 \\
\hline 122.00 & 6.00 & .00 & 2.00 & 121.99 & 0.29 & $0.29 \mathrm{~N}$ & $0.06 E$ & \\
\hline 124.00 & 10.00 & & 2.00 & 123.97 & & $0.56 \mathrm{~N}$ & & 1.00 \\
\hline 126.00 & 13.75 & 11.00 & 2.00 & 125.93 & 0.97 & $0.97 \mathrm{~N}$ & & .50 \\
\hline .00 & 18.00 & 1.00 & 2.00 & 127. & 1.5 & $.51 \mathrm{~N}$ & & 12.50 \\
\hline 130.00 & 21.50 & 11.00 & 2.00 & 129.74 & 2.17 & $2.17 \mathrm{~N}$ & $0.42 E$ & 75.00 \\
\hline 132.00 & 26.00 & 11.00 & 2.00 & 131.5 & 2.96 & $2.96 \mathrm{~N}$ & $0.58 \mathrm{E}$ & \\
\hline 134.00 & 30.00 & 10.00 & 2.00 & 133.33 & 3.88 & $3.88 \mathrm{~N}$ & $0 . \pi E$ & 201.37 \\
\hline 136.00 & 35.00 & 8.00 & 2.00 & 135.02 & 4.94 & $4.94 . N$ & $0.91 E$ & 255.68 \\
\hline 138.00 & 39.25 & 7.00 & 2.00 & 136.61 & 6.1 & $6.14 \mathrm{~N}$ & $1.07 E$ & 214.63 \\
\hline $140.00^{\circ}$ & 43.50 & 6.00 & 2.00 & 138.11 & 7.45 & $7.45 \mathrm{~N}$ & $1.22 \mathrm{E}$ & 215.05 \\
\hline .00 & 7.5 & & 2.00 & 139. & 8.8 & 8.87 & & \\
\hline & 51.50 & & 2.00 & 160.82 & 10. & $39 N$ & & 200.00 \\
\hline 146.00 & 53.00 & 6.00 & 2.00 & 142.04 & 11.96 & $11.96 \mathrm{~N}$ & 1.7 & 75.00 \\
\hline .00 & 56.00 & 7.0 & 2.00 & 143.20 & 13. & $13.58 \mathrm{~N}$ & & 155.42 \\
\hline 150.00 & 59.00 & 8.00 & 2.00 & 144.28 & 15.25 & $15.25 \mathrm{~N}$ & $2.10 \mathrm{E}$ & 155.8 \\
\hline 152.00 & 61.50 & & 2.00 & 145.27 & 16.97 & $16.97 \mathrm{~N}$ & $2.36 \mathrm{E}$ & \\
\hline 154.00 & 63.00 & 10.00 & 2.00 & 146.20 & 18.71 & $18.71 \mathrm{~N}$ & $2.65 E$ & 87.08 \\
\hline 156.00 & 64.50 & 10.00 & 2.00 & 147.08 & 20.48 & $20.48 \mathrm{~N}$ & $2.96 \mathrm{E}$ & 75.01 \\
\hline 158.00 & 66.25 & 9.00 & 2.00 & 147.92 & 22.27 & $22.27 \mathrm{~N}$ & $3.26 \mathrm{E}$ & 98.60 \\
\hline 160.00 & 68.50 & 9.00 & 2.00 & 148.69 & 24.09 & $24.09 \mathrm{~N}$ & $3.55 \mathrm{E}$ & 112.50 \\
\hline 163.00 & 74.00 & 9.00 & 3.00 & 169.65 & 26.90 & & & 183.33 \\
\hline 165.00 & 78.50 & 10.00 & 2.00 & 150.13 & 28.82 & & & 230.18 \\
\hline 167.00 & 83.50 & 10.00 & 2.00 & 150.44 & 30.76 & $30.76 \mathrm{~N}$ & $4.66 \mathrm{E}$ & 250.00 \\
\hline 169.00 & 87.51 & 11.00 & 2.00 & 150.60 & 32.72 & $32.72 \mathrm{~N}$ & $5.02 \mathrm{E}$ & 206.12 \\
\hline 171.00 & 90.00 & 10.00 & 2.00 & 150.64 & 34.69 & $34.69 \mathrm{~N}$ & $5.38 \mathrm{E}$ & 134.62 \\
\hline
\end{tabular}




\begin{tabular}{|c|c|c|c|c|c|c|c|c|}
\hline \multirow{3}{*}{$\begin{array}{l}\text { OU PONT } \\
\text { ATH - } 1 \\
\text { Measured } \\
\text { Depth }\end{array}$} & \multirow[b]{3}{*}{$\begin{array}{l}\text { Drift } \\
\text { Angle }\end{array}$} & \multirow[b]{3}{*}{$\begin{array}{c}\text { Drift } \\
\text { Direction }\end{array}$} & \multirow[b]{3}{*}{$\begin{array}{l}\text { Course } \\
\text { Length }\end{array}$} & \multicolumn{2}{|c|}{$\begin{array}{l}\text { Slot : }\langle 001\rangle \\
\text { Well: }\end{array}$} & \multirow{2}{*}{\multicolumn{3}{|c|}{$\begin{array}{l}\text { Dote Printed : } 19-0 C T-88 \\
\text { Our Ref : } 500163.402\end{array}$}} \\
\hline & & & & PEH & $: \quad 0.00$ & & & \\
\hline & & & & $\begin{array}{l}\text { Vertical } \\
\text { Depth }\end{array}$ & $\begin{array}{l}\text { Vertical } \\
\text { Section }\end{array}$ & $\begin{array}{l}\text { REC C T A A I } \\
C O O O R O\end{array}$ & $\begin{array}{l}\text { GULAR } \\
\text { NATES }\end{array}$ & $\begin{array}{l}\text { Dogleg } \\
\text { Severity }\end{array}$ \\
\hline 173.00 & 90.00 & 10.00 & 2.00 & 150.64 & 36.66 & $36.66 \mathrm{~N}$ & $5.73 E$ & 0.00 \\
\hline 175.00 & 90.00 & 10.00 & 2.00 & 150.64 & 38.63 & $38.63 \mathrm{~N}$ & $6.08 \mathrm{E}$ & 0.00 \\
\hline 177.00 & 89.50 & 10.00 & 2.00 & 150.65 & 40.60 & $40.60 \mathrm{~N}$ & $6.43 E$ & 25.00 \\
\hline 179.00 & 89.00 & 10.00 & 2.00 & 150.67 & 42.57 & $42.57 \mathrm{~N}$ & $6.77 \mathrm{E}$ & 25.00 \\
\hline 181.00 & 88.50 & 9.00 & 2.00 & 150.72 & 44.54 & $44.54 \mathrm{~N}$ & $7.10 \mathrm{E}$ & 55.89 \\
\hline 191.00 & 88.00 & 10.00 & 10.00 & 151.02 & 54.40 & $54.40 \mathrm{~N}$ & $8.75 \mathrm{E}$ & 11.18 \\
\hline 201.00 & 87.75 & 10.00 & 10.00 & 151.39 & 64.24 & $64.24 \mathrm{~N}$ & $10.49 E$ & 2.50 \\
\hline 211.00 & 87.00 & 10.00 & 10.00 & 151.85 & 74.08 & $74.08 \mathrm{~N}$ & $12.22 \mathrm{E}$ & 7.50 \\
\hline 221.00 & 90.00 & 17.00 & 10.00 & 152.11 & 83.80 & $83.80 \mathrm{~N}$ & $14.56 \mathrm{E}$ & 76.13 \\
\hline 231.00 & 95.00 & 16.00 & 10.00 & 151.68 & 93.38 & $93.38 \mathrm{~N}$ & $17.39 \mathrm{E}$ & 50.99 \\
\hline 41.00 & 88.00 & 18.00 & 10.00 & 151.42 & 102.93 & $102.93 \mathrm{~N}$ & $20.32 \mathrm{E}$ & 72.80 \\
\hline 31.00 & 87.50 & 18.00 & 10.00 & 151.81 & 112.4 & $112.44 \mathrm{~N}$ & $23.40 \mathrm{E}$ & 5.00 \\
\hline 261.00 & 84.50 & 18.00 & 10.00 & 152.51 & 121.93 & $121.93 \mathrm{~N}$ & $26.49 E$ & 30.00 \\
\hline 271.00 & 83.25 & 18.00 & 10.00 & 153.57 & 131.38 & $131.38 \mathrm{~N}$ & $29.56 \mathrm{E}$ & 12.50 \\
\hline 281.00 & 82.50 & 18.00 & 10.00 & 154.81 & 140.82 & $140.82 \mathrm{~N}$ & $32.63 \mathrm{E}$ & 7.50 \\
\hline 291.00 & 83.00 & 19.00 & 10.00 & 156.08 & 150.23 & $150.23 N$ & & 11.11 \\
\hline 301.00 & 82.25 & 20.00 & 10.00 & 157.36 & 159.57 & $159.57 \mathrm{~N}$ & $39.08 \mathrm{E}$ & 12.43 \\
\hline 311.00 & 81.75 & 21.00 & 10.00 & 158.75 & 168.85 & $168.85 \mathrm{~N}$ & $42.55 \mathrm{E}$ & 11.09 \\
\hline 321.00 & 82.00 & .00 & 10.00 & 160.16 & 178.12 & $178.12 \mathrm{~N}$ & $46.02 E$ & 10.21 \\
\hline 331.00 & 82.00 & 18.00 & 10.00 & 161.56 & 187.49 & $187.49 \mathrm{~N}$ & $49.24 \mathrm{E}$ & 19.81 \\
\hline 341.00 & 79.00 & 18.00 & 10.00 & 163.21 & 196.87 & $196.87 \mathrm{~N}$ & & 30.00 \\
\hline 351.00 & 79.00 & & 10.00 & 165.12 & 206.20 & $206.20 \mathrm{~N}$ & $55.32 \mathrm{E}$ & 0.00 \\
\hline 361.00 & 79.00 & 18.00 & 10.00 & 167.02 & 215.54 & $215.54 \mathrm{~N}$ & $58.36 \mathrm{E}$ & 0.00 \\
\hline & 81.50 & 21.00 & 10.00 & 168.72 & 224.83 & $224.83 \mathrm{~N}$ & $61.65 \mathrm{E}$ & 38.72 \\
\hline 381.00 & 81.50 & 21.00 & 10.00 & 170.19 & 234.06 & $234.06 \mathrm{~N}$ & $65.19 \mathrm{E}$ & 0.00 \\
\hline 394.00 & 83.0 & 24. & 13.00 & 171.95 & 245.9 & $245.96 \mathrm{~N}$ & & 25.61 \\
\hline & 84.0 & & 10.00 & 173.08 & 254.89 & $254.89 \mathrm{~N}$ & & 40.98 \\
\hline 414.00 & 84.5 & 29.00 & 10.00 & 174.08 & 263.64 & $263.64 \mathrm{~N}$ & $79.22 \mathrm{E}$ & 11.14 \\
\hline & 85.5 & 38.00 & 10.00 & 174.95 & 272.31 & $272.31 \mathrm{~N}$ & & 14.12 \\
\hline 434.00 & 87.00 & 31.00 & 10.00 & 175.61 & 280.90 & $280.90 \mathrm{~N}$ & $89.19 \mathrm{E}$ & 18.02 \\
\hline
\end{tabular}




\begin{tabular}{|c|c|c|c|c|c|c|c|c|c|}
\hline \multirow{2}{*}{$\begin{array}{l}\text { OU PONT } \\
\text { ANH - } 1 \\
\text { Measured } \\
\text { Depth }\end{array}$} & \multirow[b]{2}{*}{$\begin{array}{l}\text { Drift } \\
\text { Angle }\end{array}$} & \multirow[b]{2}{*}{$\begin{array}{c}\text { Drift } \\
\text { Direction }\end{array}$} & \multirow[b]{2}{*}{$\begin{array}{l}\text { Course } \\
\text { Length }\end{array}$} & \multicolumn{2}{|c|}{$\begin{array}{l}\text { Slot : (001) } \\
\text { Well: }\end{array}$} & \multicolumn{3}{|c|}{$\begin{array}{ll}\text { Date Printed } & : 19-0 C T-88 \\
\text { Our Ref } & : 500163.402\end{array}$} & \multirow[t]{3}{*}{ Page : } \\
\hline & & & & $\begin{array}{l}\text { Uertical } \\
\text { Depth }\end{array}$ & $\begin{array}{l}\text { Vertical } \\
\text { Section }\end{array}$ & \multicolumn{2}{|c|}{$\begin{array}{l}\text { RECTANGULAR } \\
\text { COOROINATES }\end{array}$} & $\begin{array}{l}\text { Dogleg } \\
\text { Severity }\end{array}$ & \\
\hline $\begin{array}{l}444.00 \\
454.00 \\
464.00 \\
474.00 \\
484.00\end{array}$ & $\begin{array}{l}88.00 \\
89.25 \\
90.00 \\
90.00 \\
92.00\end{array}$ & $\begin{array}{l}36.90 \\
31.00 \\
32.00 \\
36.00 \\
38.00\end{array}$ & $\begin{array}{l}10.00 \\
10.00 \\
10.00 \\
10.00 \\
10.00\end{array}$ & $\begin{array}{l}176.04 \\
176.28 \\
176.35 \\
176.35 \\
176.17\end{array}$ & $\begin{array}{l}289.51 \\
298.13 \\
306.65 \\
314.94 \\
322.93\end{array}$ & $\begin{array}{l}289.51 \mathrm{~N} \\
298.13 \mathrm{~N} \\
306.65 \mathrm{~N} \\
314.96 \mathrm{~N} \\
322.93 \mathrm{~N}\end{array}$ & $\begin{array}{r}94.27 \mathrm{E} \\
99.36 \mathrm{E} \\
104.56 \mathrm{E} \\
110.16 \mathrm{E} \\
116.17 \mathrm{E}\end{array}$ & $\begin{array}{l}14.14 \\
16.01 \\
12.50 \\
40.00 \\
28.28\end{array}$ & \\
\hline \multicolumn{3}{|c|}{$\begin{array}{l}\text { CALCULATION METHOD : An } \\
\text { SLOT COORDINATES : } \\
\text { BOTTOM HOLE LOCATION : RE } \\
\text { OISTANCE : } \\
\text { OIRECTION : }\end{array}$} & $\begin{array}{l}\text { gle Avera } \\
0.00 \mathrm{~N} \\
\text { ferenced } \\
343.19 \\
19.79\end{array}$ & $\begin{array}{l}\text { ging } \\
0.00 \\
\text { to SLOT }\end{array}$ & & \multicolumn{2}{|c|}{ Report Units : Feet } & & \\
\hline
\end{tabular}




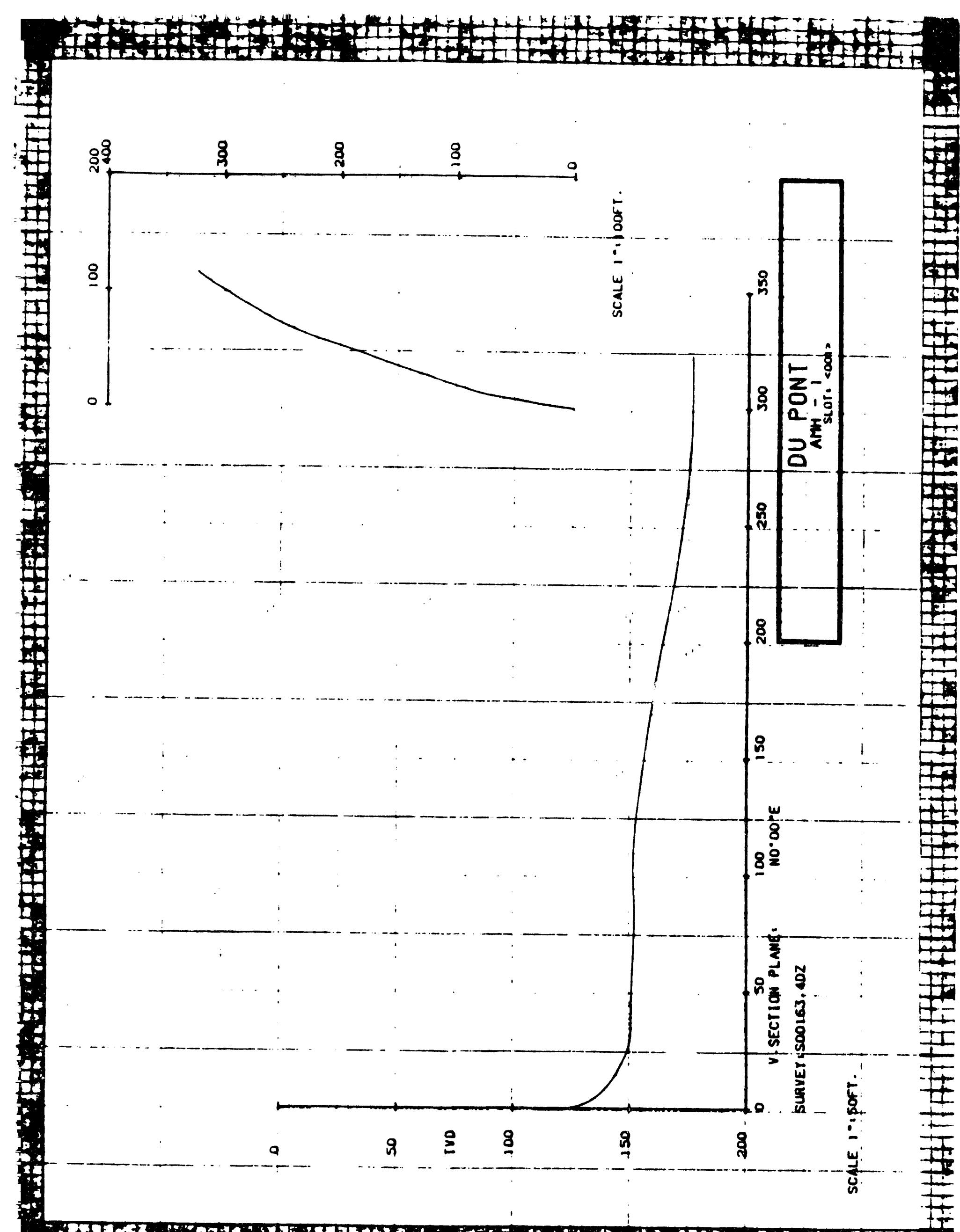

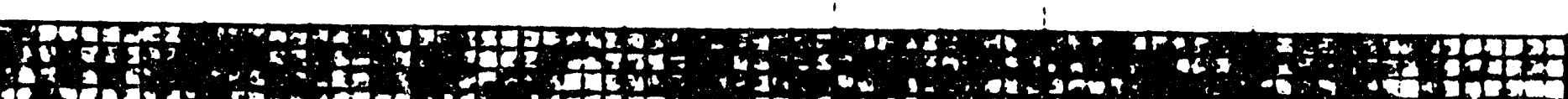

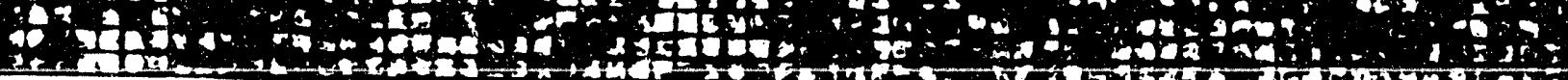




\section{EASTMAN CHRISTENSEN COMPANY}

LATERAL ORILLING

WELL DEFLECTION SURUEY

$$
\text { for }
$$

DU PONT

ANH - 2

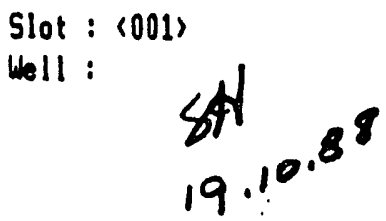

Survey Reference : S00167.40Z 


\begin{tabular}{|c|c|c|c|c|c|c|c|c|}
\hline \multirow{3}{*}{$\begin{array}{l}\text { DU PONT } \\
\text { AMH - ? } \\
\text { Measired } \\
\text { Drpth }\end{array}$} & & & & \multicolumn{2}{|c|}{$\begin{array}{l}\text { Slot : (001) } \\
\text { Well: }\end{array}$} & \multirow{2}{*}{\multicolumn{2}{|c|}{$\begin{array}{l}\text { Dote Printed } \\
\text { Our Ref }\end{array}$}} & \multirow[t]{2}{*}{$\begin{array}{l}20-0 C T-88 \\
500167.40\end{array}$} \\
\hline & & & & PBHL & 0.00 & & & \\
\hline & $\begin{array}{l}\text { Drift } \\
\text { Angle }\end{array}$ & $\begin{array}{l}\text { Drift } \\
\text { Oirection }\end{array}$ & $\begin{array}{l}\text { Course } \\
\text { Length }\end{array}$ & $\begin{array}{l}\text { Vertical } \\
\text { Depth }\end{array}$ & $\begin{array}{l}\text { Vertical } \\
\text { Section }\end{array}$ & \multicolumn{2}{|c|}{$\begin{array}{l}\text { RECTANGULAR } \\
\text { COOROINATES }\end{array}$} & $\begin{array}{l}\text { Dogleg } \\
\text { Soverity }\end{array}$ \\
\hline 23.00 & 1.00 & 148.00 & 0.00 & 23.00 & 0.00 & $0.00 \mathrm{~N}$ & $0.00 E$ & 0. \\
\hline 25.00 & 1.00 & 165.00 & 2.00 & 25.00 & -0.03 & $0.03 \mathrm{~s}$ & $0.01 \mathrm{E}$ & 14.78 \\
\hline 27.00 & 3.00 & 180.00 & 2.00 & 27.00 & -0.10 & $0.10 \mathrm{~S}$ & $0.02 E$ & 102.52 \\
\hline 29.00 & 7.50 & 180.00 & 2.00 & 28.99 & -0.28 & $0.28 \mathrm{~S}$ & $0.02 \mathrm{E}$ & 225.00 \\
\hline 31.00 & 10.75 & 185.00 & 2.00 & 30.96 & -0.60 & $0.60 \mathrm{~S}$ & $0.01 E$ & 167.12 \\
\hline 33.00 & 14.00 & 185.00 & 2.00 & 32.92 & -1.03 & $1.03 \mathrm{~s}$ & $0.03 \mathrm{~W}$ & 162.50 \\
\hline 35.00 & 17.00 & 185.00 & 2.00 & 34.85 & -1.56 & $1.56 \mathrm{~S}$ & $0.07 \mathrm{~W}$ & 150.00 \\
\hline 37.00 & 20.00 & 185.00 & 2.00 & 36.74 & -2.19 & $2.19 \mathrm{~S}$ & $0.13 \mathrm{~W}$ & 150.00 \\
\hline 39.00 & 24.00 & 187.00 & 2.00 & 38.60 & -2.94 & $2.94 \mathrm{~S}$ & $0.21 \mathrm{~W}$ & 203.45 \\
\hline 41.00 & 28.00 & 188.00 & 2.00 & 40.39 & -3.81 & $3.81 \mathrm{~S}$ & $0.32 \mathrm{H}$ & 201.19 \\
\hline 43.00 & 32.50 & 189.00 & 2.00 & 42.12 & -4.80 & $4.80 \mathrm{~S}$ & $0.47 \mathrm{~W}$ & 226.40 \\
\hline 45.00 & 37.00 & 190.00 & 2.00 & 43.77 & -5.93 & $5.93 \mathrm{~S}$ & $0.66 \mathrm{H}$ & 226.79 \\
\hline \multicolumn{6}{|c|}{ CACCLLATION RETHOO : Angle Averaging } & \multicolumn{3}{|c|}{ Report Units : Feet } \\
\hline \multirow{2}{*}{\multicolumn{9}{|c|}{$\begin{array}{l}\text { SLOT COOROINATES : } 0.00 \mathrm{~N} \text { 0.00 E } \\
\text { BOTTOH HOLE LOCATION : Referenced to SLOT }\end{array}$}} \\
\hline & & & & & & & & \\
\hline \multicolumn{9}{|c|}{$\begin{array}{rc}\text { OISTANCE: } & 5.96 \\
\text { OIRECTION : } & 186.35\end{array}$} \\
\hline
\end{tabular}




\section{EASTMAN CHRISTENSEN COMPANY}

LATERAL DRILLING

WELL DEFLECTION SURUEY

$$
\text { for }
$$

OW PONT

$$
\text { ANA - } 2 B
$$

Slot: (001) $\quad\langle f t .0 .88$

Survay Reference : S00164.40Z 


\begin{tabular}{|c|c|c|c|c|c|c|c|c|}
\hline \multirow{2}{*}{$\begin{array}{l}\text { OU PONT } \\
\text { ANA - } 2 B \\
\text { Measured } \\
\text { Depth }\end{array}$} & \multirow[b]{2}{*}{$\begin{array}{l}\text { Orift } \\
\text { Angle }\end{array}$} & \multirow[b]{2}{*}{$\begin{array}{c}\text { Orift } \\
\text { Direction }\end{array}$} & \multirow[b]{2}{*}{$\begin{array}{l}\text { Course } \\
\text { Length }\end{array}$} & \multicolumn{2}{|c|}{$\begin{array}{l}\text { Slot : }\langle 001\rangle \\
\text { Hell : }\end{array}$} & $\begin{array}{l}\text { Oate } \\
\text { Our } 5\end{array}$ & inted : $:$ & $\begin{array}{l}19-0 C T-88 \\
500164.402\end{array}$ \\
\hline & & & & $\begin{array}{l}\text { Vertical } \\
\text { Depth }\end{array}$ & $\begin{array}{l}\text { Vertical } \\
\text { Section }\end{array}$ & \multicolumn{2}{|c|}{$\begin{array}{l}\text { RECTANGULAR } \\
\text { COOROINATES }\end{array}$} & $\begin{array}{l}\text { Dogleg } \\
\text { Severity }\end{array}$ \\
\hline 25.00 & 0.50 & 356.00 & 0.00 & 25.00 & 0.01 & $0.01 \mathrm{~N}$ & $0.01 \mathrm{~W}$ & 0.00 \\
\hline 27.00 & 0.50 & & 2.00 & & 0.1 & $.03 \mathrm{~N}$ & $0.01 \mathrm{~W}$ & 0.00 \\
\hline 29.00 & 5.00 & 356.00 & 2.00 & 29.00 & 0.12 & $0.12 \mathrm{~N}$ & $0.02 \mathrm{~W}$ & 225.00 \\
\hline 31.00 & 8.00 & 356.00 & 2.00 & 30.5 & 0.35 & $0.35 \mathrm{~N}$ & $0.03 \mathrm{~W}$ & 50.00 \\
\hline 33.00 & 10.50 & 353.00 & 2.00 & 32.96 & 0.67 & $0.67 \mathrm{~N}$ & $0.06 \mathrm{~W}$ & 125.00 \\
\hline 35.00 & 14.00 & 356.00 & 2.00 & 34.91 & 1.09 & $1.09 \mathrm{H}$ & $0.09 \mathrm{H}$ & 175.00 \\
\hline 37.00 & 18.50 & 356.0 & 2.00 & 36.8 & 1.65 & $1.65 \mathrm{~N}$ & $0.12 W$ & 25.00 \\
\hline 39.00 & 22.00 & 356.00 & 2.00 & 38.71 & 2.34 & $2.34 \mathrm{~N}$ & $0.17 \mathrm{~W}$ & 175.00 \\
\hline 41.00 & 26.00 & 358.00 & 2.00 & 40.54 & 3.15 & $3.15 \mathrm{~N}$ & $0.22 W$ & 204.87 \\
\hline 43.00 & 29.50 & 358.00 & 2.00 & 2.31 & 4.08 & $4.08 \mathrm{~N}$ & $0.25 \mathrm{H}$ & 75.00 \\
\hline 45.00 & .00 & 354.00 & 2.00 & 44.1 & 5.12 & $5.12 \mathrm{~K}$ & 0.324 & .96 \\
\hline 47.00 & 37.00 & 355.00 & 2.00 & 45.65 & 6.26 & $6.26 \mathrm{~N}$ & $0.43 \mathrm{~W}$ & 202.04 \\
\hline 69.00 & 42.00 & 355.00 & 2.00 & 47.20 & 7.53 & $7.53 \mathrm{~N}$ & $0.54 \mathrm{U}$ & 250.00 \\
\hline 51.00 & 45.00 & 355.00 & 2.00 & 48.65 & 8.91 & $8.90 \mathrm{~N}$ & $0.66 \mathrm{~W}$ & 150.00 \\
\hline 53.00 & 48.50 & 356.00 & 2.00 & 50.02 & 10.35 & $10.35 \mathrm{~N}$ & $0.78 \mathrm{u}$ & 178.75 \\
\hline 55.00 & 52.00 & 356.00 & 2.00 & 51.30 & 11.69 & $1.89 \mathrm{~N}$ & $0.88 \mathrm{H}$ & 175.00 \\
\hline 57.00 & 55.50 & 3 & 2.00 & 52. & 13.5 & $3.50 \mathrm{~N}$ & $10 \mathrm{H}$ & 175.00 \\
\hline 59.00 & 59.00 & 356.00 & 2.00 & 53.56 & 15.17 & $15.17 \mathrm{~N}$ & $1.11 \mathrm{w}$ & 175.00 \\
\hline 61.00 & 61.00 & 356.00 & 2.00 & 54.56 & 16.90 & $16.90 \mathrm{~N}$ & $1.23 \mathrm{H}$ & 100.00 \\
\hline 63.00 & 64.00 & 356.00 & 2.00 & 55.49 & 18.67 & $18.67 \mathrm{~N}$ & $1.36 \mathrm{~V}$ & 150.00 \\
\hline 65.00 & 67.00 & 356.00 & 2.00 & 56.32 & 20.6 & 20.49 & & \\
\hline 67.00 & 70.00 & 356.00 & 2.00 & 57.05 & 22.3 & 22.34 & & 150.00 \\
\hline 69.00 & 72.50 & 356.00 & 2.00 & 57.69 & 24.2 & 24.23 & & 125.00 \\
\hline 71.00 & 76.00 & 356.00 & 2.00 & 58.23 & 26. & 26.15 & $1.88 \mathrm{~W}$ & 175.00 \\
\hline 73.00 & 77.50 & 352.00 & 2.00 & 58.69 & 28.09 & $28.09 \mathrm{~N}$ & $2.08 \mathrm{U}$ & 208.62 \\
\hline 75.00 & 77.50 & 353.00 & 2.90 & 59.13 & 30.0 & $30.02 \mathrm{~N}$ & $2.34 \mathrm{~W}$ & 48.81 \\
\hline 77.00 & 78.50 & 355.60 & 2.00 & 59.54 & 31.97 & $31.97 \mathrm{~N}$ & $2.54 \mathrm{H}$ & 109.85 \\
\hline 79.00 & 82.50 & 36.00 & 2.00 & 59.87 & 33.94 & $33.96 \mathrm{~N}$ & $2.70 \mathrm{~W}$ & 205.99 \\
\hline 81.00 & 86.00 & 37.01 & 2.00 & 60.07 & 35.92 & $35.92 \mathrm{~N}$ & $2.84 \mathrm{H}$ & 175.00 \\
\hline 83.00 & 89.00 & 356.00 & 2.00 & 60.16 & 37.91 & $37.91 \mathrm{~N}$ & $2.98 \mathrm{H}$ & 150.00 \\
\hline
\end{tabular}




\begin{tabular}{|c|c|c|c|c|c|c|c|c|}
\hline \multirow{2}{*}{$\begin{array}{l}\text { DU PONT } \\
\text { AIH - } 28 \\
\text { Measured } \\
\text { Depth }\end{array}$} & \multirow[b]{2}{*}{$\begin{array}{l}\text { Drift } \\
\text { Angle }\end{array}$} & \multirow[b]{2}{*}{$\begin{array}{c}\text { Drift } \\
\text { Direction }\end{array}$} & \multirow[b]{2}{*}{$\begin{array}{l}\text { Course } \\
\text { Length }\end{array}$} & \multicolumn{2}{|c|}{$\begin{array}{l}\text { Slot : (001) } \\
\text { Hell: }\end{array}$} & \multicolumn{2}{|c|}{$\begin{array}{l}\text { Date Printed: } \\
\text { Our Ref : }\end{array}$} & \multirow[b]{2}{*}{$\begin{array}{l}\text { Dogleg } \\
\text { Severily }\end{array}$} \\
\hline & & & & $\begin{array}{l}\text { Vertica! } \\
\text { Depth }\end{array}$ & $\begin{array}{l}\text { Vertical } \\
\text { Section }\end{array}$ & \multicolumn{2}{|c|}{$\begin{array}{l}R E C T A N G U L A R \\
C O O R O I N A T E S\end{array}$} & \\
\hline 85.00 & 90.00 & 355.00 & 2.00 & 60.18 & 39.91 & $39.91 \mathrm{~N}$ & $3.13 \omega$ & 70.71 \\
\hline 87.00 & 90.00 & 355. & 2.00 & 60.18 & 41.90 & $41.90 \mathrm{~N}$ & $3.31 \mathrm{~W}$ & 0.00 \\
\hline 90.00 & 89.50 & 354.00 & 3.00 & 60.19 & 44.89 & $44.89 \mathrm{~N}$ & $3.59 \mathrm{H}$ & 37.27 \\
\hline 100.00 & 88.00 & 354.00 & 10.00 & 60.41 & 54.83 & $54.83 \mathrm{~N}$ & $4.64 \mathrm{~W}$ & 15.00 \\
\hline 110.00 & 88.00 & 354.00 & 10.00 & 60.76 & 64.77 & $64.77 \mathrm{~N}$ & $5.68 \mathrm{~W}$ & 0.00 \\
\hline 120.00 & 87.00 & 354.00 & 10.00 & 61.19 & 74.70 & $74.70 \mathrm{~N}$ & $6.73 \mathrm{~W}$ & 10.00 \\
\hline 130.00 & 87.00 & 356.00 & 10.00 & 61.72 & 84.65 & $84.65 \mathrm{~N}$ & $7.60 \mathrm{~W}$ & 19.97 \\
\hline 140.00 & 87.00 & 356.00 & 10.00 & 62.24 & 94.62 & $94.62 \mathrm{~N}$ & $8.30 \mathrm{~W}$ & 0.00 \\
\hline 150.00 & 87.50 & 356.00 & 10.00 & 62.72 & 104.58 & $104.58 \mathrm{~N}$ & $8.99 \mathrm{~W}$ & 5.00 \\
\hline 160.00 & 87.50 & 356.00 & 10.00 & 63.16 & 114.55 & $114.55 \mathrm{~N}$ & $9.69 \mathrm{~W}$ & 0.00 \\
\hline 170.00 & 9.50 & 356.00 & 10.00 & 63.59 & 124.51 & $124.51 \mathrm{~N}$ & $10.39 \mathrm{~W}$ & 0.00 \\
\hline 180.00 & 87.00 & 358.00 & 10.00 & 64.07 & 134.49 & $134.49 \mathrm{~N}$ & $10.91 \mathrm{~W}$ & 20.5 \\
\hline 190.00 & 87.00 & 360.00 & 10.00 & 64.60 & 144.47 & $144.47 \mathrm{~N}$ & $11.00 \mathrm{~W}$ & 19.97 \\
\hline 200.00 & 83.50 & 358.00 & 10.00 & 65.42 & 154.44 & $154.44 N$ & $11.26 \mathrm{~W}$ & 40.28 \\
\hline 210.00 & 83.00 & 359.00 & 10.00 & 66.60 & 164.36 & $164.36 \mathrm{~N}$ & $11.52 \mathrm{H}$ & 11.12 \\
\hline 220.00 & 83.50 & 358.00 & 10.00 & 67.77 & 174.29 & $174.29 \mathrm{~N}$ & & 11.12 \\
\hline 285.00 & 83.50 & 358.00 & 65.00 & 75.13 & 238.83 & $238.83 \mathrm{~N}$ & $14.03 \mathrm{~W}$ & 0.00 \\
\hline \multicolumn{6}{|c|}{ CALCULATION KETKOO : Angle Averaging } & \multicolumn{3}{|c|}{ Report Units : Feet } \\
\hline s.o & COOPOI & NATES : & $0.00 \mathrm{~N}$ & $0.00 E$ & & & & \\
\hline \multicolumn{9}{|c|}{ BOTTOH HOLE LOCATION : Refarenced to SLOT } \\
\hline & 0 & Teums & & & & & & \\
\hline
\end{tabular}


EASTMAN CHRISTENSEN COMPANY

LATERAL DRILLING

WELL DEFLECTION SURVEY

for

OW POUT

A NH - IC

Slot : (001)

Hell:

St.

19.10 .88

Survey Reference: 500165.402 
OU PONT

Arry - $2 \mathrm{C}$
Slot : (001)

Well:

PQHL :
Date Printed : 19-0CT-88

Our Ref

: 500165.402

Measured Drift Drift Course Vertical Vertical RECTANGULAR Dogleg Depth Angle Direction Length Depth Section COOROINATES Severity

\begin{tabular}{|c|c|c|c|c|c|c|c|c|}
\hline 34.00 & 2.00 & 4.00 & 0.00 & 34.00 & 0.06 & $0.06 \mathrm{~N}$ & $0.01 E$ & 0.00 \\
\hline 36.00 & 2.50 & 4.00 & 2.00 & 36.00 & 0.14 & $0.14 \mathrm{~N}$ & $0.02 \mathrm{E}$ & 25.00 \\
\hline 38.00 & 3.50 & 4.00 & 2.00 & 38.00 & 0.24 & $0.24 \mathrm{~N}$ & $0.02 E$ & 50.00 \\
\hline 40.00 & 7.00 & 4.00 & 2.00 & 39.99 & 0.43 & $0.43 \mathrm{~N}$ & $0.04 \mathrm{E}$ & 175.00 \\
\hline 42.00 & 10.00 & 4.00 & 2.00 & 41.97 & 0.72 & $0.72 \mathrm{~N}$ & $0.06 E$ & 150.00 \\
\hline 44.00 & 13.75 & 4.00 & 2.00 & 43.92 & 1.13 & $1.13 \mathrm{~N}$ & $0.08 E$ & 187.50 \\
\hline 46.00 & 18.00 & 4.00 & 2.00 & 45.85 & 1.68 & $1.68 \mathrm{~N}$ & $0.12 \mathrm{E}$ & 212.50 \\
\hline 48.00 & 22.00 & 4.00 & 2.00 & 47.73 & 2.36 & $2.36 \mathrm{~N}$ & $0.17 \mathrm{E}$ & 200.00 \\
\hline 50.00 & 25.00 & 4.00 & 2.00 & 49.56 & 3.15 & $3.15 \mathrm{~N}$ & $0.23 E$ & 150.00 \\
\hline 52.00 & 28.50 & 4.00 & 2.00 & 51.35 & 4.05 & $4.05 \mathrm{~N}$ & $0.29 E$ & 175.00 \\
\hline 54.00 & 32.50 & 4.00 & 2.00 & 53.07 & 5.07 & $5.07 \mathrm{~N}$ & $0.36 E$ & 200.00 \\
\hline 56.00 & 36.00 & 4.00 & 2.00 & 54.72 & 6.19 & $6.19 \mathrm{~N}$ & $0.44 \mathrm{E}$ & 175.00 \\
\hline 58.00 & 39.00 & 4.00 & 2.00 & 56.31 & 7.40 & $7.40 \cdot N \cdot$ & $0.52 E$ & 150.00 \\
\hline 60.00 & 42.50 & 4.00 & 2.00 & 57.82 & 8.70 & $8.70 \mathrm{~N}$ & $0.61^{\prime} E$ & 175.00 \\
\hline 62.00 & 46.00 & 4.00 & 2.00 & 59.26 & 10.10 & $10.10 N$ & $0.71 \mathrm{E}$ & 175.00 \\
\hline 64.00 & 49.00 & 4.00 & 2.00 & 60.61 & 11.57 & $11.57 \mathrm{~N}$ & $0.81 E$ & 150.00 \\
\hline 66.00 & 52.50 & 4.00 & 2.00 & 61.87 & 13.11 & $13.11 \mathrm{~N}$ & $0.92 E$ & 175.00 \\
\hline 68.00 & 55.50 & $4.00^{\circ}$ & 2.00 & 63.05 & 14.73 & $14.73 N$ & $1.04 \mathrm{E}$ & 150.00 \\
\hline 70.00 & 58.50 & 5.00 & 2.00 & 64.14 & 16.40 & $16.40 \mathrm{~N}$ & $1.17 \mathrm{E}$ & 155.75 \\
\hline 72.00 & 61.50 & 6.00 & 2.00 & 65.14 & 18.12 & $18.12 \mathrm{~N}$ & $1.33 \mathrm{E}$ & 156.12 \\
\hline 74.00 & 64.00 & 7.00 & 2.00 & 66.05 & 19.89 & $19.89 \mathrm{~N}$ & $1.53 \mathrm{E}$ & 132.67 \\
\hline 76.00 & 67.00 & 8.00 & 2.00 & 66.88 & 21.69 & $21.69 \mathrm{~N}$ & $1.77 \mathrm{E}$ & 156.75 \\
\hline 78.00 & 70.00 & 9.00 & 2.00 & 67.62 & 23.53 & $23.53 \mathrm{~N}$ & $2.05 \mathrm{E}$ & 157.05 \\
\hline 80.00 & 73.00 & 10.00 & 2.00 & 68.25 & 25.41 & $25.41 \mathrm{~N}$ & $2.36 \mathrm{E}$ & 157.31 \\
\hline 82.00 & 76.00 & 10.00 & 2.00 & 68.79 & 27.30 & $27.30 \mathrm{~N}$ & $2.69 E$ & 150.00 \\
\hline 84.00 & 79.50 & 10.00 & 2.00 & 69.21 & 29.23 & $29.23 \mathrm{~N}$ & $3.03 \mathrm{E}$ & 175.00 \\
\hline 86.00 & 82.00 & 11.00 & 2.00 & 69.53 & 31.17 & $31.17 \mathrm{~N}$ & $3.39 \mathrm{E}$ & 134.39 \\
\hline 88.00 & 85.00 & 11.00 & 2.00 & 69.76 & 33.12 & $33.12 \mathrm{~N}$ & $3.77 \mathrm{E}$ & 150.00 \\
\hline 91.00 & 87.25 & 12.00 & 3.00 & 69.96 & 36.05 & $36.05 \mathrm{~N}$ & $4.37 E$ & 82.04 \\
\hline 101.00 & 85.50 & 12.00 & 10.00 & 70.59 & 45.81 & $45.81 \mathrm{~N}$ & $6.44 \mathrm{E}$ & 17.50 \\
\hline
\end{tabular}




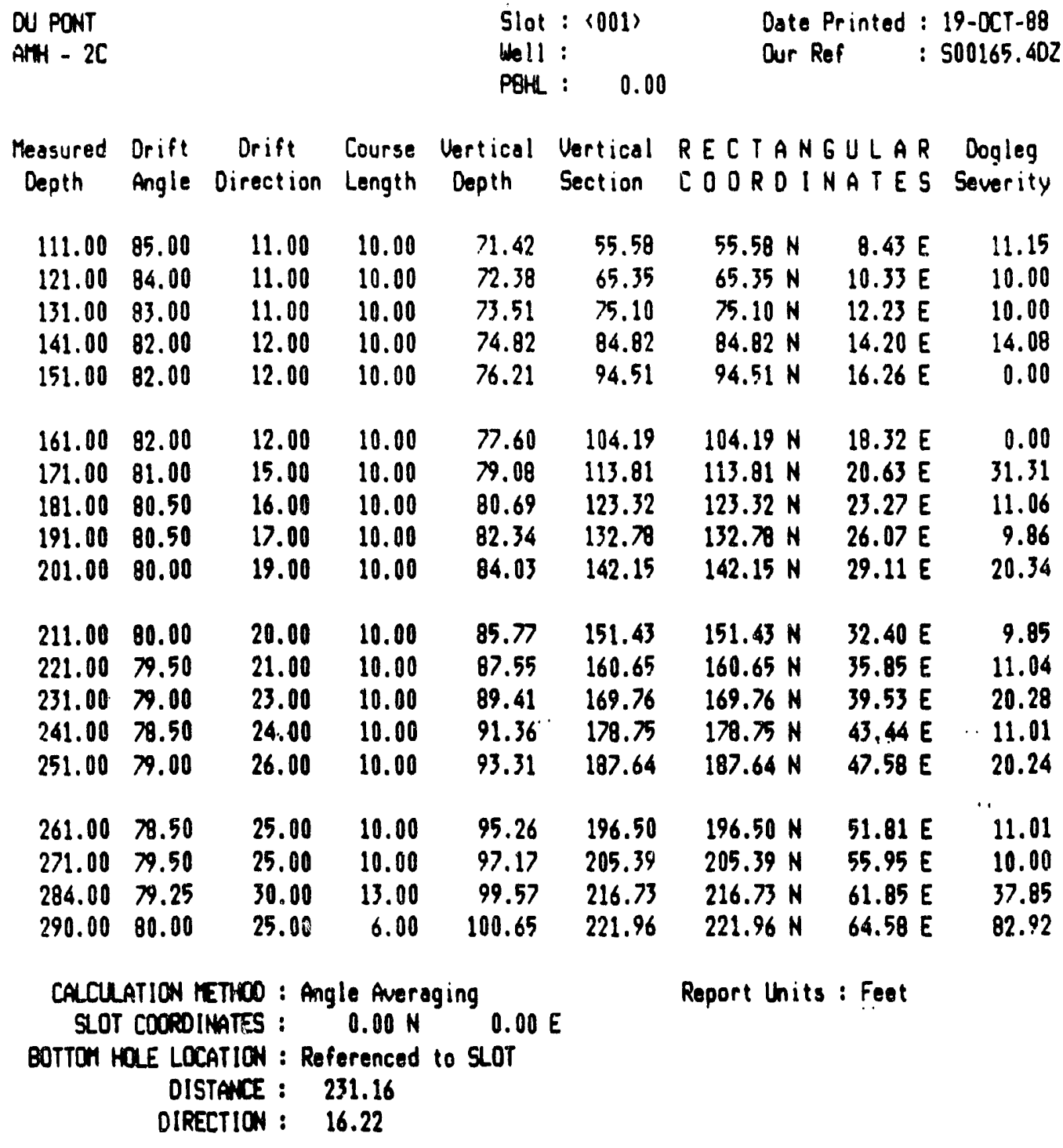




\section{EASTMAN CHRISTENSEN COMPANY}

LATERAL ORILLING

WELL DEFLECTION SLRUEY

for

DU PONT

$$
\begin{aligned}
& \text { Ant - } 20 \\
& \text { Slot : } 1001\rangle \\
& \text { Well : }
\end{aligned}
$$

Survey Reforence : 500166.402 


\begin{tabular}{|c|c|c|c|c|c|c|c|c|}
\hline \multirow{3}{*}{$\begin{array}{l}\text { OU PONT } \\
\text { ANH - } 20 \\
\text { Measured } \\
\text { Depth }\end{array}$} & \multirow[b]{3}{*}{$\begin{array}{l}\text { Drift } \\
\text { Angle }\end{array}$} & \multirow[b]{3}{*}{$\begin{array}{l}\text { Drift } \\
\text { Direction }\end{array}$} & \multirow[b]{3}{*}{$\begin{array}{l}\text { Course } \\
\text { Length }\end{array}$} & \multicolumn{2}{|c|}{$\begin{array}{l}\text { Slot : }\langle 001\rangle \\
\text { Well : }\end{array}$} & \multirow{2}{*}{\multicolumn{3}{|c|}{$\begin{array}{ll}\text { Date Printed }: & 19-0 C T-88 \\
\text { Our Ref } & \text { S00166.402 }\end{array}$}} \\
\hline & & & & & $\therefore \quad 0.00$ & & & \\
\hline & & & & \multirow{2}{*}{$\begin{array}{l}\text { Uertical } \\
\text { Depth } \\
23.00\end{array}$} & $\begin{array}{l}\text { Vertical } \\
\text { Section }\end{array}$ & \multicolumn{2}{|c|}{$\begin{array}{l}\text { REC CTANGULA R } \\
\text { COOOROINA ATES }\end{array}$} & $\begin{array}{l}\text { Dogleg } \\
\text { Severity }\end{array}$ \\
\hline 23.00 & 0.50 & 347.00 & 0.00 & & 0.01 & $0.01 \mathrm{~N}$ & $0.01 \mathrm{~W}$ & 0.00 \\
\hline 25.00 & 0.50 & 347.00 & 2.00 & 25.00 & 0.03 & $.03 \mathrm{~N}$ & $0.01 \mathrm{~W}$ & 0.00 \\
\hline 27.00 & 1.00 & 347.00 & 2.00 & 27.00 & 0.05 & $0.05 \mathrm{~N}$ & $0.02 \mathrm{~W}$ & 25.00 \\
\hline 29.00 & 4.00 & 347.00 & 2.00 & 29.00 & 0.14 & $0.14 \mathrm{~N}$ & $0.04 \mathrm{~W}$ & 150.00 \\
\hline 31.00 & 8.50 & 347.00 & 2.00 & 30.99 & 0.35 & $0.35 \mathrm{~N}$ & $0.09 \mathrm{~W}$ & 225.00 \\
\hline 33.00 & .50 & & 2.00 & 32.96 & 0.69 & $0.69 \mathrm{~N}$ & $.17 \mathrm{~W}$ & \\
\hline 35.00 & 14.75 & & 2.00 & 34.90 & 1.1 & $1.13 \mathrm{~N}$ & $0.27 \mathrm{H}$ & 162.50 \\
\hline 37.00 & 18.00 & 347.00 & 2.00 & 36.82 & 1.68 & $1.68 \mathrm{~N}$ & $0.40 \mathrm{H}$ & 162.50 \\
\hline 39.00 & 22.00 & 347.00 & 2.00 & 38.7 & 2.2 & $2.35 \mathrm{~N}$ & $0.55 \mathrm{H}$ & .00 \\
\hline 41.00 & 25.50 & 367.00 & 2.00 & 40.53 & 3.13 & $3.13 \mathrm{~N}$ & $0.73 \mathrm{H}$ & 175.00 \\
\hline 43.00 & 28.00 & 347.00 & 2.00 & 42.32 & 4.01 & $4.01 \mathrm{~N}$ & $0.93 \mathrm{H}$ & 125.00 \\
\hline 45.00 & 31.00 & 347.00 & 2.00 & 44.06 & 6.97 & $4.97 \mathrm{~N}$ & $1.15 \mathrm{~W}$ & 150.00 \\
\hline 47.00 & 35.00 & .347 .00 & 2.00 & 45.74 & 6.03 & $6.03 \mathrm{~N}$ & $1.40 \mathrm{H}$ & 200.00 \\
\hline 49.00 & 38.00 & 347.00 & 2.00 & 47.34 & 7.19 & $7.19 \mathrm{~N}$ & $1.67 \mathrm{~W}$ & 150.00 \\
\hline $51.00^{\circ}$ & 41.00 & 347.00 & 2.00 & 49.89 & 8.43 & $8.43 \mathrm{~N}$ & $1.95 \mathrm{H}$ & 150.00 \\
\hline 53.00 & 44.00 & & 2.00 & 50.36 & 9.7 & 9.74 & & \\
\hline 55.00 & 47.50 & 3.47 .00 & 2.00 & 51.76 & 11.14 & $11.14 \mathrm{~N}$ & $2.58 W$ & 175.00 \\
\hline 57.00 & 51.00 & 347.00 & 2.00 & 53.06 & 12.62 & $12.62 \mathrm{~N}$ & $2.92 \mathrm{~W}$ & 175.00 \\
\hline 59.00 & 54.00 & 347.00 & 2.00 & 54.28 & 14.16 & 14.16 & $3.28 \mathrm{H}$ & \\
\hline 61.00 & 57.00 & 347.00 & 2.00 & 55.41 & 15.77 & $15.77 \mathrm{~N}$ & $3.65 \mathrm{H}$ & 150.00 \\
\hline 63.00 & 60.00 & 347.00 & 2.00 & 56.46 & 17.43 & $17.43 \mathrm{~N}$ & $4.03 \mathrm{~W}$ & \\
\hline 65.00 & 63.50 & 347.00 & 2.00 & 57.40 & 19.15 & $19.15 \mathrm{~N}$ & $4.43 \mathrm{~V}$ & 175.00 \\
\hline 67.00 & 66.25 & 347.00 & 2.00 & 58.25 & 20.91 & $20.91 \mathrm{~N}$ & $4.84 \mathrm{~W}$ & 137.50 \\
\hline 69.00 & 70.00 & & & 59.00 & 22.72 & $22.72 \mathrm{~N}$ & & 187.50 \\
\hline 71.00 & 73.00 & 347.00 & 2.00 & 59.63 & 24.57 & $24.57 \mathrm{~N}$ & $5.68 \mathrm{H}$ & 150.00 \\
\hline 73.00 & 76.00 . & 340.00 & 2.00 & 60.17 & 26.8 & 26.45 & & \\
\hline 75.00 & 79.00 & & 2.00 & 60.60 & 28.36 & & & 150.00 \\
\hline 77.00 & 82.00 & 348.08 & 2.00 & 60.93 & 30.29 & $30.29 \mathrm{~N}$ & $6.91 \mathrm{~W}$ & 150.00 \\
\hline 79.00 & 85.00 & 348.00 & 2.00 & 61.16 & 32.23 & $32.23 \mathrm{~N}$ & $7.33 \mathrm{H}$ & 150.00 \\
\hline 81.00 & 87.50 & 340.00 & 2.00 & 61.29 & 34.18 & $34.18 \mathrm{~N}$ & $7.74 \mathrm{~W}$ & 125.00 \\
\hline
\end{tabular}




\begin{tabular}{|c|c|c|c|c|c|c|c|c|}
\hline \multirow{2}{*}{$\begin{array}{l}\text { OU POWT } \\
\text { ANH - } 20 \\
\text { Messured } \\
\text { Depth }\end{array}$} & \multirow[b]{2}{*}{$\begin{array}{l}\text { Drift } \\
\text { Angle }\end{array}$} & \multirow[b]{2}{*}{$\begin{array}{c}\text { Drift } \\
\text { Direction }\end{array}$} & \multirow[b]{2}{*}{$\begin{array}{l}\text { Course } \\
\text { Length }\end{array}$} & \multicolumn{2}{|c|}{$\begin{array}{l}\text { Slot : (001) } \\
\text { We11: }\end{array}$} & \multicolumn{2}{|c|}{$\begin{array}{l}\text { Date Printed: } \\
\text { Our Ref : }\end{array}$} & $\begin{array}{l}19-0 C T-88 \\
500166.402\end{array}$ \\
\hline & & & & $\begin{array}{l}\text { Vertical } \\
\text { Depth }\end{array}$ & $\begin{array}{l}\text { Vertical } \\
\text { Section }\end{array}$ & \multicolumn{2}{|c|}{$\begin{array}{l}R E C T A N G U L A R \\
C O O R O I N A T E S\end{array}$} & $\begin{array}{l}\text { Dogleg } \\
\text { Severity }\end{array}$ \\
\hline 90.00 & 88.00 & 346.00 & 9.00 & 61.64 & 42.95 & $42.95 \mathrm{~N}$ & $9.76 \mathrm{~W}$ & 22.89 \\
\hline 100.00 & 87.75 & 347. & 10.00 & 62.01 & 52.66 & $52.66 \mathrm{~N}$ & $12.10 \mathrm{~W}$ & 10.30 \\
\hline 110.00 & 87.00 & 347.00 & 10.00 & 62.47 & 62.40 & $62.40 \mathrm{~N}$ & $14.34 \mathrm{~W}$ & 7.50 \\
\hline 120.00 & 87.00 & 347.00 & 10.00 & 62.99 & 72.13 & $72.13 \mathrm{~N}$ & $16.59 \mathrm{~W}$ & 0.00 \\
\hline 130.00 & 86.50 & 349.00 & 10.00 & 63.56 & 81.89 & $81.89 \mathrm{~N}$ & $18.67 \mathrm{~W}$ & 20.58 \\
\hline 140.00 & .25 & & 10.00 & 64.19 & 91.7 & $91.71 \mathrm{~N}$ & $8 \mathrm{~W}$ & 1.29 \\
\hline 150.00 & 85.50 & 350.00 & 10.00 & 64.91 & 101.53 & $101.53 \mathrm{~N}$ & $22.22 \mathrm{~W}$ & 7.50 \\
\hline 160.00 & 85.00 & 350.00 & 10.00 & 65.74 & 111.34 & $111.36 \mathrm{~N}$ & $23.95 \mathrm{~W}$ & 5.00 \\
\hline 170.00 & 84.00 & 350.00 & 10.1 & 66.70 & 121.1 & $121.15 \mathrm{~N}$ & $25.68 \mathrm{~W}$ & 10.00 \\
\hline 180.00 & 84.00 & 350.00 & 10.00 & 67.74 & 130.94 & $130.94 \mathrm{~N}$ & $27.40 \mathrm{H}$ & 0.00 \\
\hline 190.00 & 83.50 & & 10.00 & 68.83 & 140.73 & $140.73 \mathrm{~N}$ & $29.13 \mathrm{H}$ & 5.00 \\
\hline 200.00 & 84.00 & 352.00 & 10.00 & 69.92 & 150.55 & $150.55 \mathrm{~N}$ & $30.68 \mathrm{~W}$ & 20.50 \\
\hline 210.00 & 83.00 & 353.00 & 10.00 & 71.05 & 160.40 & $160.40 \cdot N$ & $31.98 \mathrm{H}$ & 14.10 \\
\hline 220.00 & 83.00 & 351.00 & 10.00 & 72.27 & 170.23 & $170.23 \mathrm{~N}$ & 33.36 .4 & 19.85 \\
\hline $230.00^{\circ}$ & 83.00 & 359.00 & 10.00 & 73.49 & 180.12 & $180.12 \mathrm{~N}$ & $34.23 \mathrm{H}$ & 79.40 \\
\hline 240.00 & 87.00 & & 10.00 & 74.7 & 190. & 190. & & 41.22 \\
\hline 250.00 & 85.00 & & 10.00 & 75.06 & 200.04 & $04 \mathrm{~N}$ & 35.1 & 28.25 \\
\hline 260.00 & 84.50 & 356.00 & 10.00 & 75.98 & 209.97 & $209.97 \mathrm{~N}$ & $35.70 \mathrm{~W}$ & 5.00 \\
\hline 270.00 & 83.50 & 356.00 & 10.00 & 77.02 & 219.89 & $219.89 \mathrm{~N}$ & $36.40 \mathrm{~W}$ & 10.00 \\
\hline 280.00 & 83.50 & 356.00 & 10.00 & 78.15 & 229.80 & $229.80 \mathrm{~N}$ & $37.09 \mathrm{H}$ & 0.00 \\
\hline 283.00 & 83.50 & 356.00 & 3.00 & 78.49 & 232.78 & $232.78 \mathrm{~N}$ & $37.30 \mathrm{~W}$ & 0.00 \\
\hline $\begin{array}{l}\text { CALCUL } \\
\text { SLOT } \\
\text { BOTTOH H }\end{array}$ & $\begin{array}{l}\text { ATION I } \\
\text { COORD } \\
\text { OLE LO } \\
\text { OIS } \\
\text { OIRE }\end{array}$ & $\begin{array}{l}\text { ETHOD : A } \\
\text { INATES : } \\
\text { CATION : R } \\
\text { STANCE : } \\
\text { ECTION : }\end{array}$ & $\begin{array}{l}\text { lo Avers } \\
0.00 \mathrm{~N} \\
\text { renced } \\
35.75 \\
0.90\end{array}$ & $\begin{array}{l}n g .00 \\
\text { s.oT }\end{array}$ & & Report Un & : Feet & \\
\hline
\end{tabular}

SURLEY RUN INFORHATION 


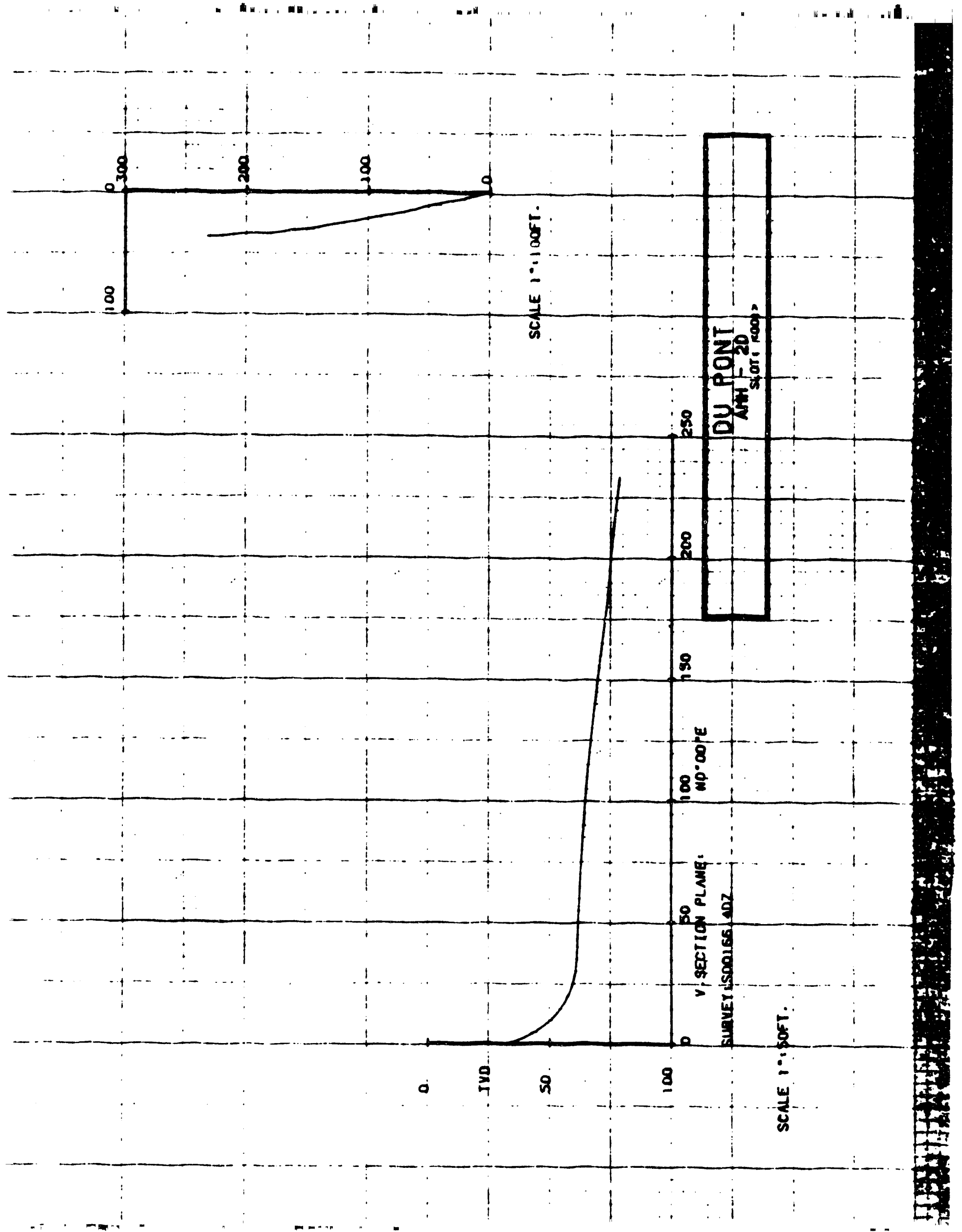


APPENDIX E

\section{WELL-CASING TALLIES}

AMH-1

AMH-2 
CASING TALLY

WELL NUMBER

AMH - 1

SCREEN DIAGRAM

(feet)

(N.T.S.)

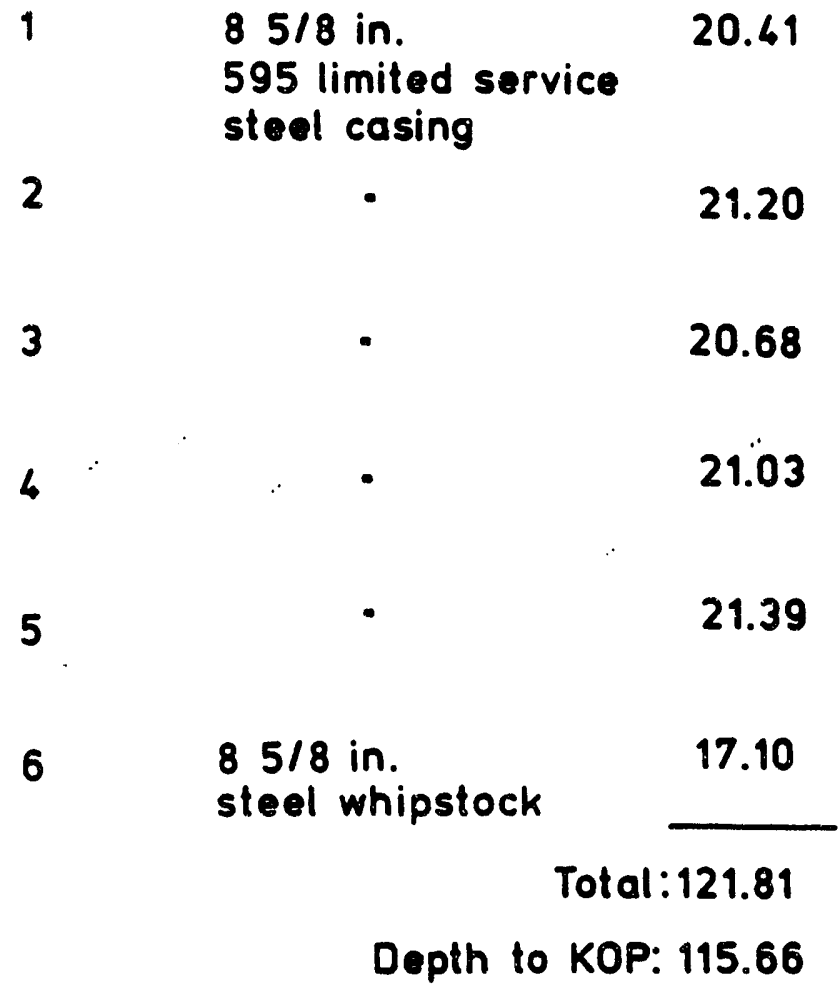

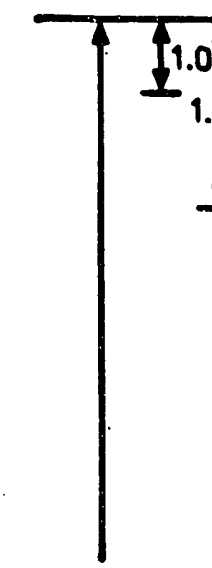

17.10

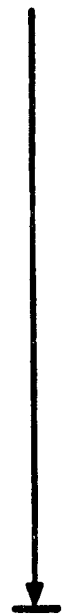

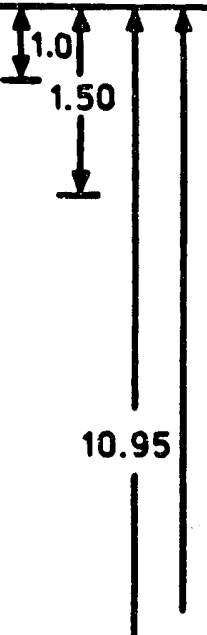

16.45

1

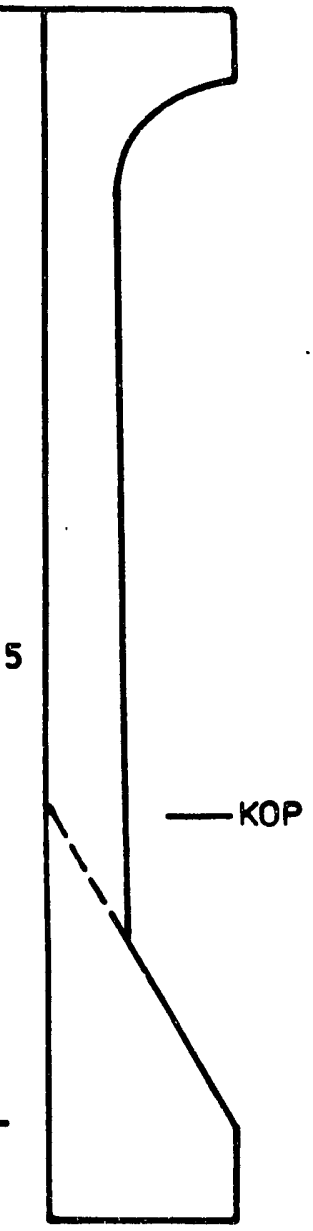


WELL NUMBER AMH-1

Paqe 1 of 2

\section{ITEM NUMBER DESCRIPTION LENGTH}

(feet)

$23 / 8$ inch EUE steel 24.35

pipe

2

$23 / 8$ inch EUE steel pipe

3

4

5

6

7

8

9

10
Inflatable packer

$23 / 8$ inch EUE steel pipe

$23 / 8$ inch EUE steel pipe

$23 / 8$ inch EUE steel

pipe

$23 / 8$ inch EUE steel pipe

$23 / 8$ inch EUE steel pipe

$23 / 8$ inch EUE steel pipe with $10-1 / 8$ inch holes per joint at $90^{\circ}$ offset pairs

$23 / 8$ inch EUE steel pipe with 10-1/8 inch holes per joint at $90^{\circ}$ offset pairs
10.10

14.47

24.35

24.39

24.41

24.25

24.37

31.67

30.88

\section{SCREEN DIAGRAM}

(N.T.S.) CONSULTANTS

\section{Client}

Savannah River Plant/

E.I. duPont deNemours \& Co.

Lob Number G-8191
Dan Cemploted

$9 / 23 / 88$ 


\section{SCREEN CASING TALLY}

WELL NUMBER

AMH - 1

Paqe 2 of 2

\section{ITEM NUMBER DESCRIPTION}

LENGTH

(feet)

\section{SCREEN DIAGRAM}

(N.T.S.)

11

$23 / 8$ inch EUE steel

30.51

pipe with 10-1/8 inch

holes per joint at

$90^{\circ}$ offset pairs

12

13

14

15

16

17

18

$$
11
$$

11

11

11

"I

II
32.90

31.55

32.88

32.94

30.45

32.33

Total $\frac{23.60}{430.40}$

Total Casing Length: $170.69 \mathrm{ft}$.

Total Screen Length: $309.71 \mathrm{ft}$. 
CASING TALLY

WELL NUMBER

AMH -2

ITEM NUMBER DESCRIPTION

LENGTH (feet)

SCREEN DIAGRAM (N.T.S.)

1

$85 / 8$ in.

14.042

595 limited service steel casing

2

$85 / 8$ in.

steel whipstock

17.25

Total: $\mathbf{3 1 . 2 9}$

Depth to KOP: 25.00

17.25

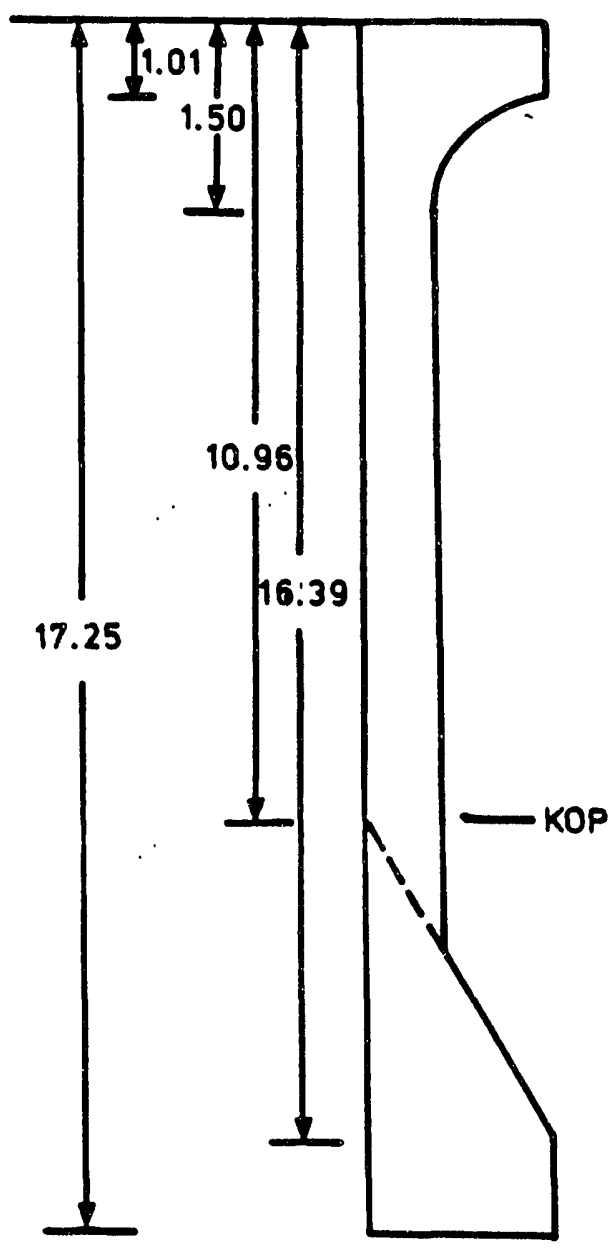

Client

Savannah River Plant/

\begin{tabular}{|c|c|}
\multicolumn{2}{c}{ DuPont De Niemur Co., Inc. } \\
M-Area Horizontal Well Project \\
\hline Job Number \\
G-8191 & Date Completed \\
$10 / 13 / 88$
\end{tabular}




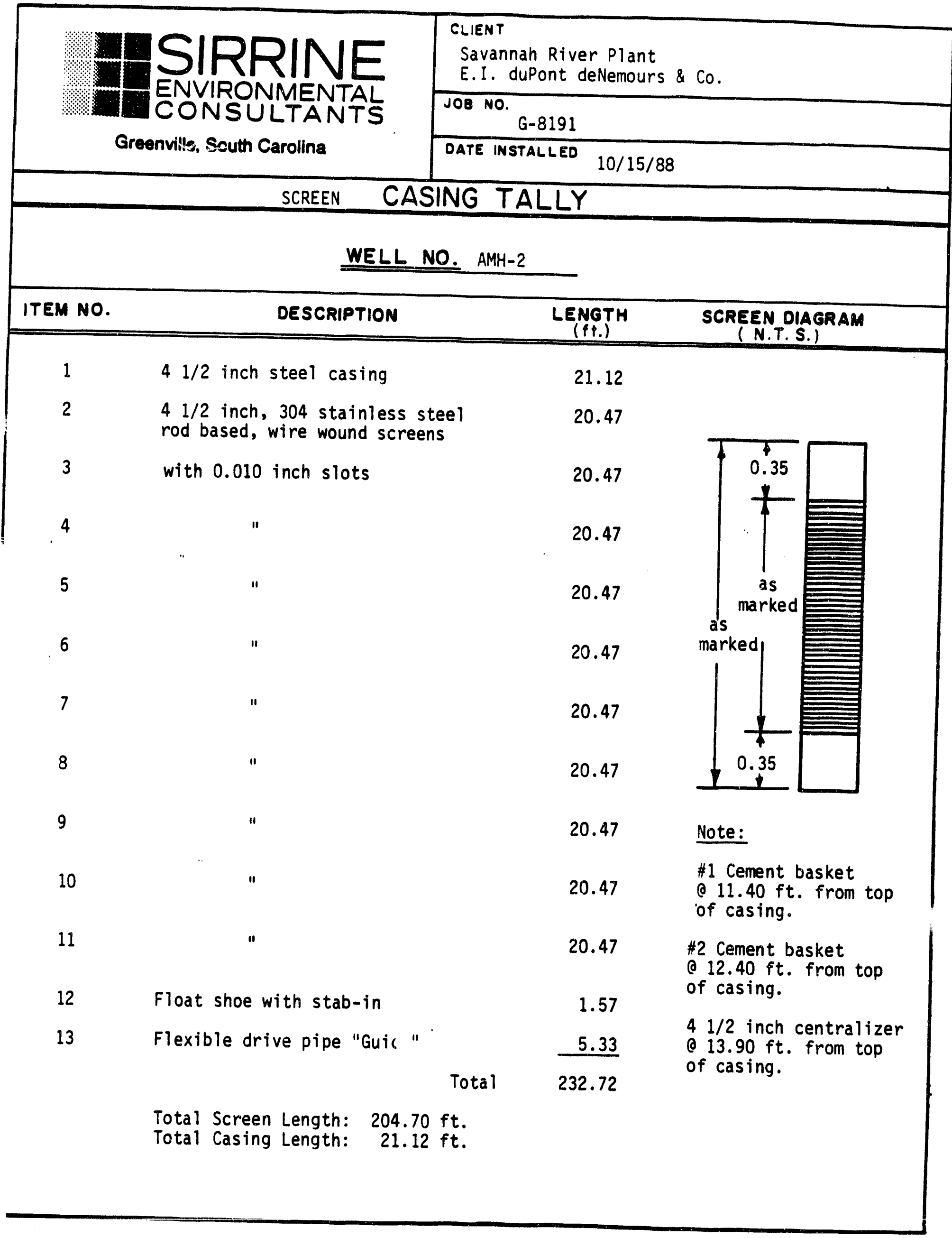




\section{APPENDIX F}

CONOCO WELL REPORT SUMMARY DATA

Well Data Summary

$$
\text { AMH-1 }
$$

AMH-2A, -2B, -2C, -2D, -2E

Drilling Fluid Performance

AMH-1

AMH-2

Directional Drilling Performance

AMH-1

AMH-2 


\section{AMH No. 1 \\ FINAL WELL REPORT \\ WELLDATA SUMMARY}

Well Name:

Spud Date:

Date Reached TD:

Rig Released:

Drilling Contractor:

Coring Rig:

Reaming Rig:

Drilling Rig:

Drilling Fluids:

Mud Engineers:

Cement and Services:

Logging:

Coring:

Rental Tools:

Fishing Tools:
AMH No. 1

9 September 1988

24 September 1988

24 September 1988

Graves Well Drilling Company, Inc.

Failing 1500

Speedstar 2000

Drilltoch DH-1

NL Baroid

D \& M Drilling Fluids, Inc.

Graves Well Drilling Company, Inc.

Graves Well Drilling Company, Inc.

Graves Well Drilling Company, Inc.

Graves Well Drilling Company, Inc.

Tri-State

Broposed

Actual

Total Depth:

$553^{\prime}$

$365^{\prime}$

$485^{\prime}$

GL (MSL):

Latitude:

Longitude:

SRP Coordinates:

Days Drilling:

8-5/8" Casing:

5-1/2" Screen:

Horizontal Azimuth:

Total Departure:

Horizontal Length:

Vertical Target:

Drilling Cost:
33.335031

81.735643

33.332325

N 103038, E 49882 N 102654.67, E 48744.19

13

20

$141^{\prime}$

$548^{\prime}$

$121^{\prime}$

*(2)*

$57.87^{\circ}(\mathrm{TN})$

$389^{\prime}$

$350^{\prime}$

$\pm 10^{\prime}$

19.790 (TN)

$343^{\prime}$

$309^{\prime}$

$26^{\prime}$

$\$ 237,579$

$\$ 463,882$

*(1)* Referenced to top of cement wellhead pad.

*(2)* Due to tools lost in the hole, the 5-1/2" screen was replaced with pre-drilled 2-3/8" tubing set at 485' 


\section{AMH No. 2 \\ FINAL WELL REPORT \\ WEILLDATA SUMMARY}

Well Name:

Spud Date:

Date Reached TD:

Rig Released:

Drilling Contractor:

Coring Rig:

Drilling Fluids:

Mud Engineers:

Cement and Services:

Logging:

Coring:

Rental Tools:

AMH No. 2A

15 September 1988

16 September 1988

24 September 1988

Graves Well Drilling Company, Inc.

Speedstar 2000

NL Baroid

D \& M Drilling Fluids, Inc.

Graves Well Drilling Company, Inc.

Graves Well Drilling Company, Inc.

Graves Well Drilling Conpany, Inc.

Graves Well Drilling Company, Inc.

Broposed

449'

$365^{\prime}$

33.334183

81.735373

N 102741, E 49765

8

36

444'

$237.87^{\circ}(\mathrm{TN})$

$350^{\prime}$

$300^{\prime}$

$\pm 10^{\prime}$

\$ 170,023
Actual

37 '

*(1)*

*(1)*

$*(1)^{*}$

$*(1)^{*}$

2

$37^{\prime}$

*(2)*

NA

$0^{\prime}$

$0^{\prime}$

NA

Drilling Cost:

Horizontal Length:

Vertical Target:

$\$ 14,200$

*(1)* Elevations and locations were not surveyed until No. 2E and the locations of Nos. 2A through 2D were lost.

*(2)* Due to misalignment of AMH No. 1, the AMH No. 2 location was moved prior to drilling the horizontal section. 


\section{AMH No. 2 \\ FINAL WELL REPORT \\ WEILDATA SUMMARY}

Well Name:

Spud Date:

Date Reached TD:

Rig Released:

Drilling Contractor:

Drilling Rig:

Drilling Fluids:

Mud Engineers:

Cement and Services:

Logging:

Coring:

Rental Tools:

AMH No. 2B

24 September 1988

26 September 1988

26 September 1988

Graves Well Drilling Company, Inc.

Drilltech DH-1

NL Baroid

D \& M Drilling Fluids, Inc.

Graves Well Drilling Company, Inc. Graves Well Drilling Company, Inc. Graves Well Drilling Company, Inc. Graves Well Drilling Company, Inc.

\section{Broposed}

449

$365^{\prime}$

GL (MSL):

Latitude:

Longitude:

SRP Coordinates:

Days Drilling:

8-5/8" Casing:

5-1/2" Screen:

Horizontal Azimuth:

Total Departure:

Horizontal Length:

Vertical Target:

Drilling Cost:
33.334183

81.735373

N 102741 , E 49765

8

$36^{\prime}$

$444^{\prime}$

$237.87^{\circ}$ (TN)

$350^{\prime}$

$300^{\prime}$

$\pm 10^{\prime}$

$\$ 170,023$
Actual

$45^{\prime}$

*(1)*

*(1)*

*(1)*

*(1)*

3

45

*(2)*

NA

$0^{\prime}$

0 '

NA

$\$ 14,436$

*(1)* Elevations and locations were not surveyed until No. 2E and the locations of Nos. 2A through 2D were lost.

*(2)* Due to misalignment of kickoff and a burst packer element on the AMH No. 2B, the AMH No. 2 location was moved prior to drilling the horizontal section. 
AMH No. 2

FINAL WELL REPORT

WELLDATA SUMMARY

Well Name:

Spud Date:

Date Reached TD:

Rig Released:

Drilling Contractor:

Drilling Rig:

Drilling Fluids:

Mud Engineers:

Cement and Services:

Logging:

Coring:

Rental Tools:

Fishing Tools:
AMH No. $2 \mathrm{C}$

27 September 1988

4 October 1988

4 October 1988

Graves Well Drilling Company, Inc.

Drilltech DH-1

NL Baroid

D \& M Drilling Fluids, Inc.

Graves Well Drilling Company, Inc.

Graves Well Drilling Company, Inc.

Graves Well Drilling Company, Inc.

Graves Well Drilling Company, Inc.

Tri-State

Proposed

Actual

Total Depth:

GL (MSL):

$449^{\prime}$

$365^{\prime}$

285'

Latitude:

Longitude:

SRP Coordinates:

33.334183

81.735373

N 102741 , E 49765

*(1)*

*(1)*

*(1)*

$*(1)^{*}$

Days Drilling:

8-5/8" Casing:

5-1/2" Screen:

Horizontal Azimuth:

Total Departure:

Horizontal Length:

Vertical Target:

Drilling Cost:
$8 \quad 8$

36

$444^{\prime}$

$237.87^{\circ}$ (TN) $\quad 356.64^{\circ}$ (TN)

$350^{\prime}$

$300^{\prime}$

$\pm 10^{\prime}$

239.24

$199.33^{\prime}$

14.95

$\$ 170,023$

$\$ 297,641$

*(1)* Elevations and locations were not surveyed until No. 2E and the locations of Nos. 2A through 2D were lost.

*(2)* Due to leaving 2-3/8" screens in the hole in the AMH No. 2C, the AMH No. 2 location was moved to re-drill the well. 


\section{AMH No. 2 \\ FINAL WELL REPORT \\ WELLDATA SUMMARY}

Well Name:

Spud Date:

Date Reached TD:

Rig Released:

Drilling Contractor:

Drilling Rig:

Drilling Fluids:

Mud Engineers:

Cement and Services:

Logging:

Coring:

Rental Tools:

Total Depth:

GL (MSL):

Latitude:

Longitude:

SRP Coordinates:

Days Drilling:

8-5/8" Casing:

5-1/2" Screen:

Horizontal Azimuth:

Total Departure:

Horizontal Length:

Vertical Target:

Drilling Cost:

AMH No. 2D

5 October 1988

10 October 1988

10 October 1988

Graves Well Drilling Company, Inc. Drilltech DH-1

NL Baroid

D \& M Drilling Fluids, Inc.

Graves Well Drilling Company, Inc.

Graves Well Drilling Company, Inc.

Graves Well Drilling Company, Inc.

Graves Well Drilling Company, Inc.

Broposed

449 '

$365^{\prime}$

33.334183

81.735373

N 102741, E 49765

8

36

$444^{\prime}$

$237.87^{\circ}$ (TN)

$350^{\prime}$

$300^{\prime}$

$\pm 10^{\prime}$

$\$ 170,023$
Actual

290'

*(1)*

*(1)*

$*(1)^{*}$

$*(1)^{*}$

6

$34^{\prime}$

*(2)*

$16.22^{\circ}(\mathrm{TN})$

$231.16^{\prime}$

$202^{\prime}$

30.89

$\$ 116,438$

*(1)* Elevations and locations were not surveyed until No. 2E and the locations of Nos. $2 \mathrm{~A}$ through 2D were lost.

*(2)* Due to hole collapse of the AMH No. 2D, the AMH No. 2 location was moved to redrill the well. 


\section{AMH No. 2 \\ FINAL WELL REPORT \\ WELLDATA SUMMARY}

Well Name:

Spud Date:

Date Reached TD:

Rig Released:

Drilling Contractor:

Drilling Rig:

Drilling Fluids:

Mud Engineers:

Cement and Services:

Logging:

Coring:

Rental Tools:

AMH No. 2E

11 October 1988

16 Dctober 1988

16 October 1988

Graves Well Drilling Company, Inc. Drilltech DH-1

NL Baroid

D \& M Drilling Fluids, Inc.

Graves Well Drilling Company, Inc.

Graves Well Drilling Company, Inc.

Graves Well Drilling Company, Inc.

Graves Well Drilling Company, Inc.

Proposed

449

$365^{\prime}$

33.334183

81.735373

N 102741, E 49765

8

36

$444^{\prime}$

$237.87^{\circ}$ (TN)

$350^{\prime}$

$300^{\prime}$

$\pm 10^{\prime}$

\$ 170,023
Actual

283'

363.04'*(1)*

33.33255

81.737831

N 102708.77, E 48807.81

6

25'

$232^{\prime} *(2)^{*}$

$350.90^{\circ}$ (TN)

$283^{\prime}$

$193^{\prime}$

17.2'

$\$ 64,108$

*(1)* Referenced to top of cement wellhead pad.

*(2)* 4-1/2" screens were run instead of 5-1/2" screens. 


\author{
AMH No. 1 \\ FINAL WELL REPORT \\ DRILLING ELUID PERFORMANCE
}

\title{
HOLE STABILTY
}

Evaluation of hole stability for the AMH No. 1 is difficult because no caliper logs could be run in the deviated section of the well. In the 16" vertical hole section a caliper survey was run. In the horizontal section the hole stability is evaluated based on bridges and difficulty in running pipe.

\section{6 " Interval}

This hole section was first cored to a diameter of 6 " with native mud and small additions of bentonite. The hole was next reamed to $12-1 / 2$ " with the same mud system. Finally the hole was opened to the full 16 " diameter using the same mud.

No caliper logs were run after reaming the hole to $16^{\prime \prime}$; however, during plugback operations it was calculated that a 50 percent washout had occurred in between 120' and 124 '. The $8-5 / 8$ " casing was run to 121 ' without hitting any bridges.

\section{6-12" and 6-1/4" Interval}

This hole section was drilled using bentonite and polymer to provide viscosity. Calcium carbonate was added to act as weight material and lost circulation material. The hole was opened to 7-7/8" using the same mud system. No calipers were run in this interval.

Only one tight spot was noted during drilling operations. On a trip going into the hole, a tight spot was noted at 241 '. This tight spot did not occur on any subsequent trips. The drill string was stuck in the hole after reaming to TD. The string was parted at the casing shoe $\left(119^{\prime}\right)$. The drill string appears to have been hung up on the casing window after the Cal-Seal around the casing shoe was eroded by drilling operations. Hole conditions do not appear to have contributed to the stuck pipe because a string of 2-3/8" tubing was run to TD beside the fish with no problems. If hole collapse had caused the stuck pipe, a bridge would have been seen while running the tubing. Later, a string of tubing was run beside the fish for completion purposes. This string was run without circulation and was again run without problem to TD. 


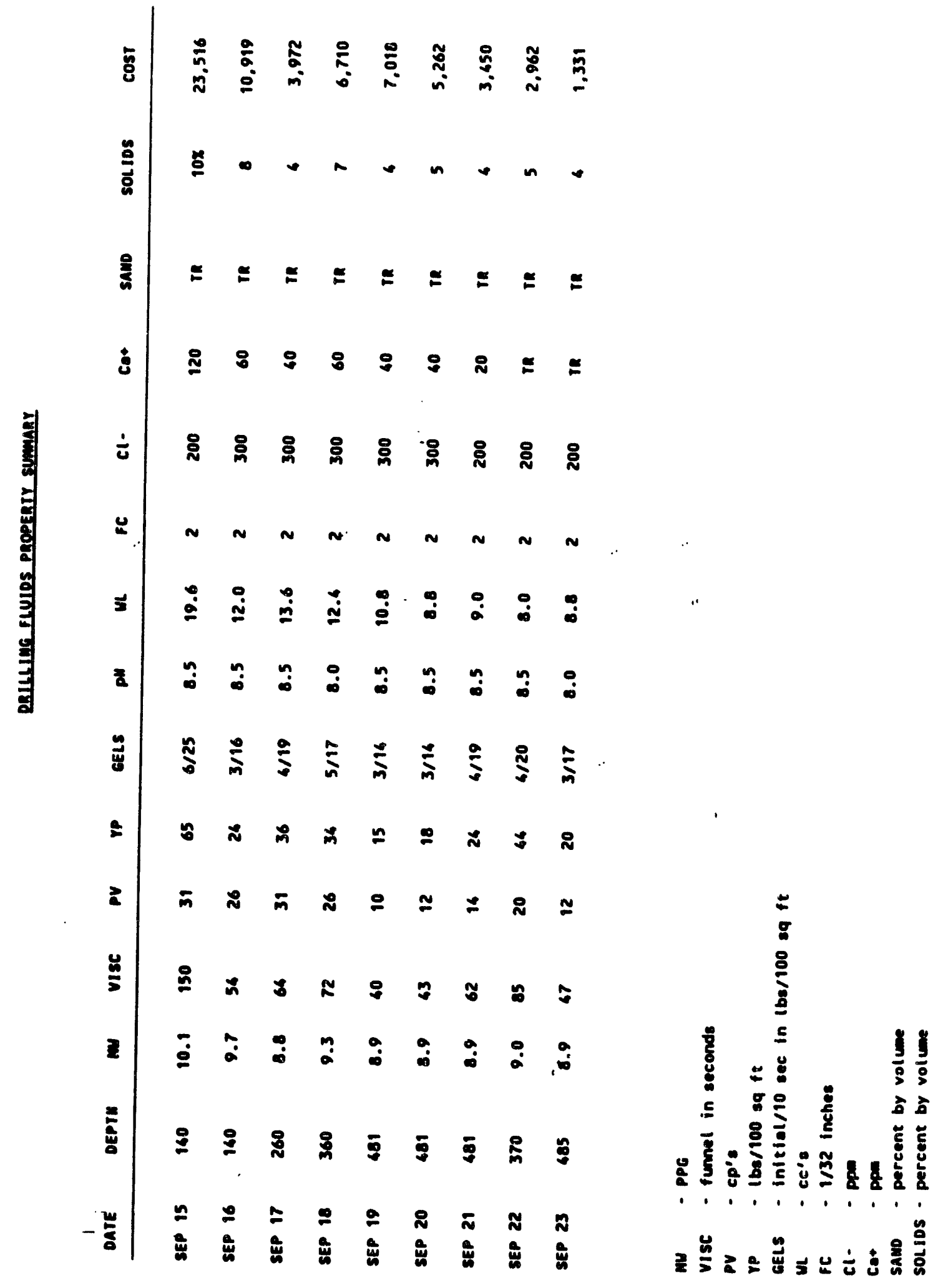




\section{AMH No. 2 \\ FINAL WELL REPORT \\ DRILLING ELUID PERFORMANCE}

\section{HOLE STABILTY}

Evaluation of hole stability for the AMH No. 2 wells is difficult because no caliper logs were run in any of the wells. Hole stability is evaluated based on bridges and difficulty in running pipe.

\section{6 " Interval}

In the AMH No. 2A, this hole section was first cored to a diameter of $6 "$ with native mud and small additions of bentonite. The hole was next reamed to $16^{\prime \prime}$ with the same mud system. In the $\mathrm{AMH}$ No. 2B through 2E, the hole was drilled to a 16" diameter on the first pass. No difficulties due to hole instability in the vertical section were reported for any of the attempts.

\section{6-3/4", 6-1/2" and 6-1/4" Interval}

This hole section was drilled using a lignosulfonate system. The lignosulphonate system disperses clays and shales to achieve hole stability and hole cleaning. This differs from the polymer system used on the AMH No. 1 which used a polymer to provide viscosity and to inhibit shales and clays from swelling. Calcium carbonate was added to act as weight material and lost circulation material. On AMH Nos. 2C and 2D, the hole was opened to 7-7/8" using the same mud system.

Several hole problems related to the mud system were experienced during drilling of the horizontal sections on AMH Nos. 2C, 2D, and 2E. Bridges and hole collapse was experienced on all three wells. This contrasts sharply with the very stable hole conditions found in the AMH No. 1 where the polymer extended bentonite system was used.

On the AMH No. 2C, a bridge or hole collapse was first encountered on September 29 during running of the aluminum wigglies for a magnetic multishot survey. A bridge was found at $120^{\prime}$ and circulation and rotation were required to work the pipe through the tight spot. On October 4, after the 2-3/8" screens were lost in the hole, it was attempted to push the fish to bottom. However, $60,000 \mathrm{lbs}$. of pulldown did not move the fish. It is suspected that the hole had collapsed on the fish.

Total depth of 290' (MD) on the AMH No. 2D was reached on October 7 and the hole was circulated and conditioned. During drilling, the horizontal section had been wiped on nearly all connections and circulated frequently. None of the prior horizontals (including No. 1) had been wiped at connections. However, a tight spot was encountered at $140^{\prime}$ on the trip out of the hole. The pipe had to be circulated out of the hole to get past the tight spot. On October 8, the 4-1/2" screens were run in the hole. A bridge or hole collapse was encountered at 55'. The screens were pulled and the hole cleaned out to 145'. The next day, October 9, total hole collapse was encountered at 132' while trying to clean out the hole with the hole opener. A magnetic multishot taken later in the day indicated a large washout existed at 55'. These complications resulted in abandonment of AMH No. 2D. 
Hole collapse was also experienced on the successful AMH No. 2E. The hole was drilled to a total depth of 285' (MD); but, the hole was not opened to 7-7/8" as had been the AMH Nos. 1, 2C, and 2D. The screens hit collapsed hole at 232' when run on October 15. This collapse resulted in the loss of 53' of horizontal section.

In summary, it is believed that the lignosulfonate mud systern contributed to the hole instability problems experienced during the drilling of the AMH Nos. $2 \mathrm{C}, 2 \mathrm{D}$, and $2 \mathrm{E}$. 


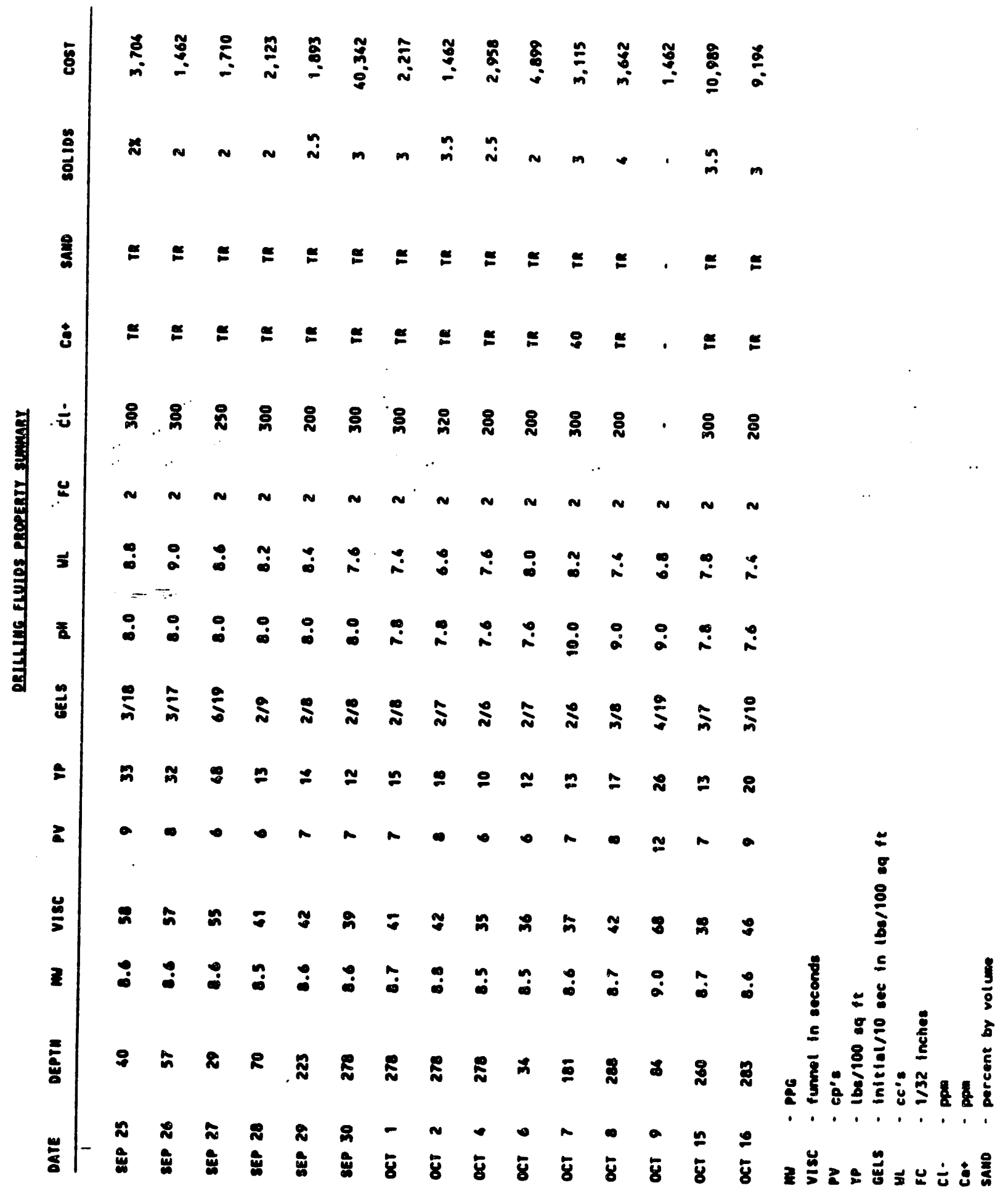


AMH No. 1

FINAL WELL REPORT

\section{DIRECTIONAL DRILLING PERFORMANCE}

The AMH No. 1 was drilled using Eastman Christensen's short radius technology. The kickoff was attained using a whipstock permanently mounted in a joint of 8-5/8" casing. This joint was the casing shoe on the vertical portion of the hole. The casing was aligned by scribing in the hole and using a transit to align the scribe with the desired hole direction. The hole direction was attained by setting the transit directly over the well path (i.e. directly on the line with the proposed location of AMH No. 2). This was checked by "backshooting" the No. 2 location and "tuming a $180^{\prime \prime}$ to the No. 1 well head.

It appears that this method should have been accurate to within $20^{\circ}$. The actual well azimuth is $38.08^{\circ}$ off of the desired azimuth. The error is probably the sum of the surface alignment error $\left( \pm 20^{\circ}\right)$ and error due to the BHA tendencies ( $\pm 20^{\circ}$ in azimuth and $\pm 2^{\circ}$ in TVD). The curve drilling assembly has shown a historical trend to walk to the right $20^{\circ}$ or to not walk at all. It has been hypothesized by Eastman Christensen personnel that this could be caused by formation drilling tendencies or could be caused by the drilling assembly rolling to the right on the whipstock. It was decided to set the whipstock dead on course (without any right hand lead) because the directional drilling tendencies of the formation were unknown. Analysis of this case indicates that walk was due to the drilling assembly rolling on the whipstock. The azimuth error was acceptable to Du Pont after a thorough discussion of the alternatives.

The pilot hole was opened with directional BHA No. 1. The pilot hole was drilled from $115^{\prime}$ to $119^{\prime}$ using an estimated weight on bit of $1,800 \mathrm{lbs}$ and a rotary speed of $60 \mathrm{RPM}$. Drilling torques in the pilot hole were between 500 psi and 650 psi. The rig gage actually records the hydraulic line pressures for the top drive. Drilling of the pilot hole required 15 minutes. The total operation including trip time, circulating, and drilling was 1-1/2 hours.

The curve section was drilled using directional BHA No. 2. The angle building section was drilled from $119^{\prime}$ to $170^{\prime}$ using the curve drill guide and 3 wiggly drill collars. The weight on bit was estimated to be 2,000 to 4,000 lbs and rotary speed was 60 RPM. Torques of 1,000 psi to 1,500 psi were seen while drilling the angle building section. Actual drilling took 1 hour to drill. The ROP was $51 \mathrm{fph}$ which is approximately 18 percent faster than the ROP seen in the vertical hole section with the 12-1/2" reaming bit (43 fph). The total operation took 12 hours and 45 minutes. This includes trouble time for a plugged pump intake $(0: 15)$ and lost circulation $(2: 30)$, and trouble time due to the slickline unit $(0: 15)$ and sticking the running gear $(1: 15)$. Survey time was $3-1 / 2$ hours; trip time was 3 hours; circulating time was 1 hour. The curve was then surveyed with a magnetic multishot run on aluminum wiggly drill collars. Surveying operations required 5-1/4 hours.

The horizontal section was then drilled. Directional BHA No. 3 drilled from $170^{\prime}$ to $360^{\prime}$. Between 170' and 280', an estimated weight on bit of 2000 to $3000 \mathrm{lbs}$ was used with a rotary speed of 40 RPM to 50 RPM. A torque of 1000 to 1350 psi was experienced over this interval. This interval experienced a drop of $4.2^{\prime}$ in the vertical plane and a right hand walk of 80 . The analysis does not indicate a trend which correlates directional performance in this hole section to drilling parameters. The section between $280^{\prime}$ and $360^{\prime}$ was drilled with an estimater weight on bit of 2,000 lbs and 6,000 lbs and a rotary speed between $20 \mathrm{RPM}$ and $36 \mathrm{RPM}$. Torque ranged from 1500 psi and 1700 psi. The interval experienced a drop of $12.2^{\prime}$ and no walk. While drilling 
this hole section, Eastman Christensen personnel tried to control the loss of inclination angle by reaming a trough immediately behind the bit on survey stations. The technique was hoped to cause the second stabilizer to drop and therefore tilt the bit upwards. The technique did not meet with significant success. A trip was then made to modify the BHA to increase the rate of build.

The section between $170^{\prime}$ and 360' was drilled in 4-1/4 hours for an average ROP of 44.7 fph. This is only slightly faster than the 12-1/2" reaming in the vertical section and only 88 percent as fast as the curve was drilled. The total time elapsed during drilling operations for this hole section was 15-1/4 hours. This included 3 hours trip time, 5-1/2 hours survey time, 3/4 hours circulating time, and 1-3/4 hours for attempted corrective action (troughing).

Drilling of the horizontal section continued with directional BHA No. 4. Directional BHA No. 4 is the same as directional BHA No. 3 except the upper stabilizer was removed in order to regain the lost hole inclination. Directional BHA No. 4 drilled from 360' to 485' with an estimated 2,000 lbs to 4,000 lbs weight on bit and 20 RPM to 36 RPM rotary speed. Torque between 1500 psi and 1850 psi was experienced in this hole section. Hole angle built from 790 at $361^{\prime}$ back to 900 at 464'. The final hole angle was $92{ }^{\circ}$ at $485^{\prime}$ (TD). A loss of $9.3^{\prime}$ in the vertical plane and 200 of right hand walk occurred over this section of the hole. The BHA was then tripped to take the final magnetic multishot survey using the aluminum wiggly drill collars.

The hole section between $360^{\prime}$ and $485^{\prime}$ was drilled in 4 hours and 45 minutes. This is an average ROP of $26.3 \mathrm{fph}$. This is only 59 percent of the ROP in the previous horizontal section (170' to $360^{\prime}$ ) and 61 percent of the RCP while reaming the 12-1/2" vertical section. The total time for all activities associated with drilling this hole section was 14.25 hours. This included $2-1 / 4$ hours for tripping, 4-1/2 hours for surveying, 1-1/4 hours for circulating, and 1-1/2 hours for washing and reaming.

After the multishot survey, the hole was opened using a shop built reamer and wiggly drill collars. The reamer had a bull nose which was designed to help follow the 6-1/4" hole. The cutting structure was a 4 blade drag bit design. This design was tried due to wellsite concerns that the Drillex Simplex bit specified in the well plan would not follow the hole path. It was expected that the Simplex bit would just drop angle and go back to a near vertical path. The shop built reamer cut the hole to 7-7/8" as planned in 2 hours and 45 minutes. A confirmation survey taken with the reamer at 485' (TD) indicated that the reamer was at 900 . However, the pipe became stuck at this time. It is suspected that the pipe was stuck at the whipstock rather than the bit. 


\section{AMH No. 2 \\ FINAL WELL REPORT \\ DIRECTIONALDRILING PERFORMANCE}

The AMH No. 2 wells were drilled using Eastman Christensen's short radius technology. The kickoff was attained using a whipstock permanently mounted in a joint of 8-5/8" casing. The joint in which the whipstock was mounted, was the casing shoe on the vertical portion of the hole. The casing was visually aligned by scribing in the hole. Well azimuth at the kickoff point was within $\pm 4^{\circ}$ of the desired azimuth using this method.

Two other methods of kicking off were also attempted. Both were attempted on the AMH No. 2B location. The first method was to visually orient the curved drill guide (CDG) and drill without a whipstock. Hole angle was successfully built to 37 degrees with a radius of curvature of 34 feet. However, the well was $180^{\circ}$ out in azimuth. The well was then plugged back with cement. It is unknown how the CDG was oriented opposite the desired direction. However, kicking off without a whipstock in the casing appears to be a viable option, if a single shot is taken prior to drilling to confirm the orientation of the CDG.

The second method of kicking off was to use a whipstock mounted on an inflatable packer. The packer was inflated to $400 \mathrm{psi}$ when the element burst. Subsequent discussions with various suppliers of inflatable packers and external casing packers shows that inflatables must be filled on volume instead of pressure in unconsolidated formations. It may still be possible to use a whipstock set on an inflatable packer for a kickoff. The manufacturer must be consulted to determine the proper inflation volume for a specific hole size. It may be necessary to run a caliper $\log$ to assist in determining the inflation volume.

The pilot hole was drilled with as assembly similar to Directional BHA No. 1. The pilot hole was drilled four feet past the kick off point using the drilling parameters shown on the table at the end of this section. The drilling time was 5 to 15 minutes and the total operation required 30 to 45 minutes.

The curve section was drilled using assemblies similar to Directional BHA No. 2 and the drilling parameters given in the table at the end of this section. All four attempts had radii or curvature between 30.9 feet and 34 feet. This hole section was drilled and surveyed in 5-1/2 hours without trouble. The trouble experienced on well Nos. 2C and 2D were due to rig repairs, a camera failure, and getting hung up in the casing. Actual drilling time ranged from $1-1 / 2$ hours to 3-1/2 hours. Analysis of the drilling parameters showed that weight on bit and penetration rate were not correlated to the directional tendencies. However, rotary speed appeared to be inversely correlated to the rate of angle build. It is important to note that this observation is only over a small range of weight on bit ( $0 \mathrm{lbs}$ to $1000 \mathrm{lbs}$ ) and may be different for greater weights on bit.

The horizontal section was drilled using two assemblies. The first assembly is shown as Directional BHA No. 3. This assembly has a 6" near bit stabilizer followed by a 5.72 " stabilizer. The bit size is 6-1/4". The second assembly is shown as Directional BHA No. 4. This assembly has a more aggressive build tendency. This assembly has a 6-1/4" bit, a 6" near bit stabilizer, but 
no upper stabilizer. The directional performance in the horizontal section was evaluated for correlations between drilling parameters and directional performance. No correlations were noted between either rotary speed or weight on bit with directional performance. Mud properties did show a positive correlation with directional tendencies. As is discussed in a later section, the lignosulfonate mud system used in the No. 2 wells decreased hole stability. This resulted in a tendency to drop angle more quickly than was noted in the AMH No. 1. Directional BHA No. 4 reduced this tendency adequately. 

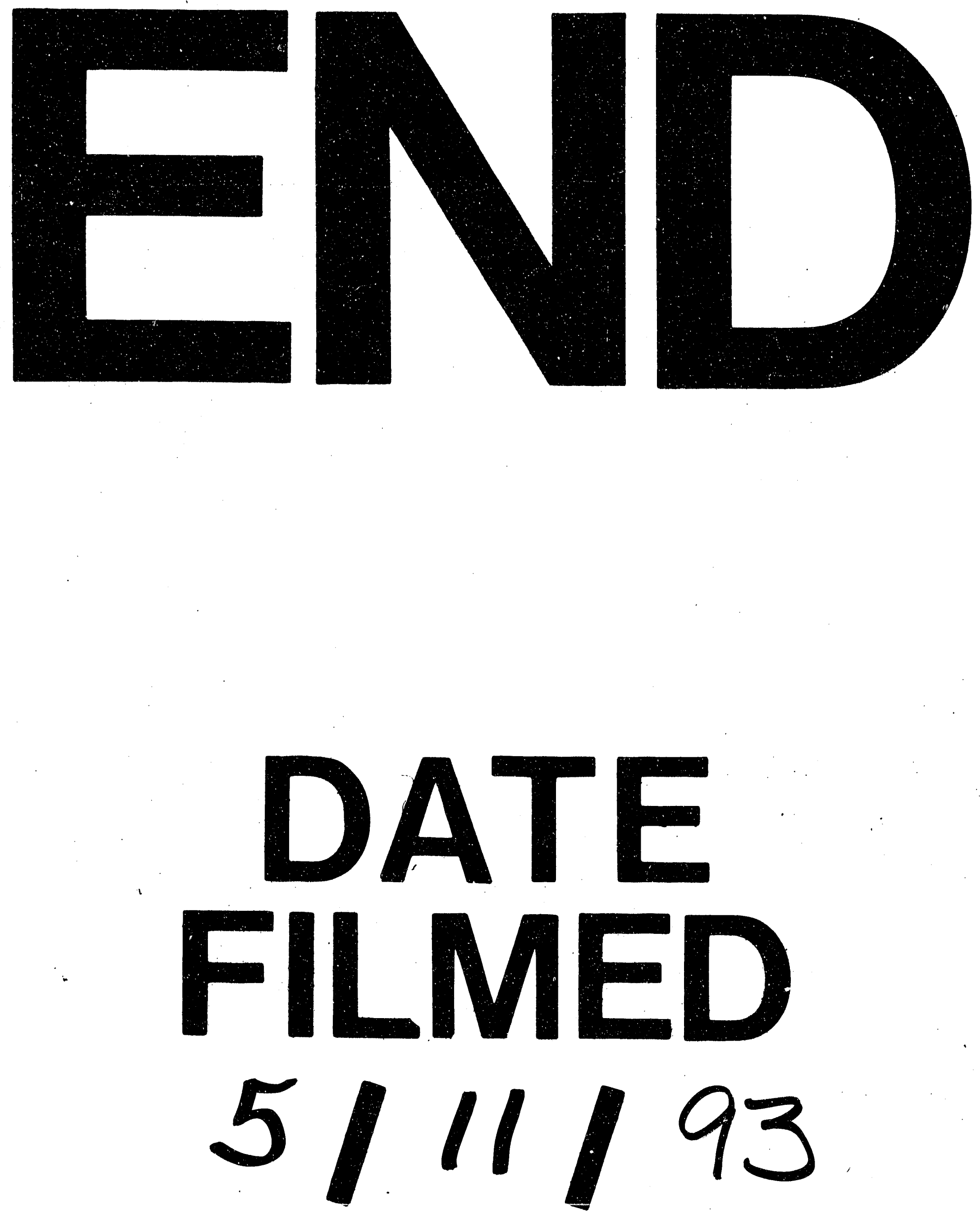

1 
